\title{
BIBLIOGRAPHY OF THE GEOLOGY, MINERALOGY, AND PALEONTOLOGY OF BRAZIL*
}

BY JOHN C. BRANNER

(Presented by title before the Society December 27, 1905)

CONTENTS

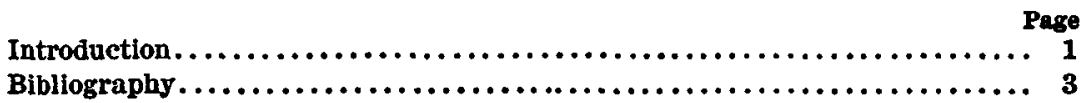

\section{INTHODOOTION}

No comprehensive bibliography of the geology of Brazil has hitherto been attempted. M. de Margerie, in his Catalogue des Bibliographies Géologiques, published in Paris in 1896 by the Congrès Géologique International; mentions six papers upon geologic subjects, each of which contains references to Brazilian geology; but none of these lists makes any pretense of being a bibliography of the geology of Brazil. In 1881 the Bibliotheca Nacional, at Rio de Janeiro, published its important Catalogo da Exposição da Historia do Brazil in two large volnmes. One of these volumes contains a list of the books and papers in the Bibliotheca Nacional that relate to the geology of Brazil, and included in this are many titles of works belonging to private individuals and not belonging to the library at that time. That is the nearest approach that has yet been made to a bibliography of the geology of Brazil. The list was necessarily imperfect; omitting the manuscripts and papers upon mineral waters, it contained only one hundred and twelve titles. A bibliography of the Mesozoic invertebrate paleontology of South America is given on pages 3 to 6 of Dr C. A. White's Contribuições á Paleontologia do Brazil, published at Rio de Janeiro in 188\%. That list contains twenty-four titles.

*An incomplete edition of this blbliography was published in the Archivos do Museu Nacional do Rio de Janciro, vol. XII, in 1803 . The proofs, however, were not seen by the author and many serious errors were overlooked by the printers. The great number of titles added, the corrections made, and the growing interest in the geology of Brazil have encouraged the Geological Society of America to publish the present list.

Dr M. A. R. Lisboa, one of the ablest of the younger Brazillan geologlsts, has now begun the publication of an annual annotated bibliography of the geology of Brazil in the Annaes da Escola de Minas. The author is glad to have future work on the subject in bis able hands. 
In 1901, the Bureau of American Republics published at Washington "A list of books, magazine articles, and maps relating to Brazil, 18001900," prepared by P. Lee Phillips, $8^{\circ}, 145$ pages. That list includes many titles upon geology and geography, but these articles are not distinguished from others, and, so far as they relate to geology, there are more omissions than titles.

The present bibliography contains over 2,000 titles, not counting abstracts, notices, and reviews.

Owing to the poverty of literature upon the geology of Brazil, many books of travel and exploration are included that make no pretense of being works upon geology, but which contain notes upon the subject of more or less value.

But though the number of titles is over 2,000, the bulk of them treat of the geology of Brazil only at second or third hand. The original papers from which most of these references are taken were written by a few men, the most important contributions being made by Agassiz, Clarke, Derby, Eschwege, Gorceix, Hussak, Lund, Rathbun, C. A. White, and Woodward, while the field work from which these results have been obtained was done by still fewer. Some of these men have also done a vast amount of work in cognate branches of science. Lund, for example, worked on zoology and botany, as well as on geology; and the papers of Luitken, Rheinhardt, and Warming on botany and zoology are the direct outcome of Lund's work in Brazil.

This list emphasizes the fact that the great bulk of the geologic work in Brazil has been done by two men-Eschwege and Derby. These men are noteworthy both for the amount and the character of their work. Eschwege's results were mostly published in German, and have therefore not been as accessible to Brazilian students as if they had been published in Portuguese or French.

Fortunately the results of Derby's work have been published in Portuguese as well as in English, and his influence upon geologic work in Brazil has been correspondingly important. Moreover, Derby's influence has extended even further than the long list of his valuable papers would indicate, for almost every modern writer upon the geology of Brazil has been inspired by Derby's work, and not a few of them have based their conclusions almost entirely upon data furnished by him.

Mr Henri Gorceix, for several years director of the Escola de Minas at Ouro Preto, has also done much to arouse an interest in the mineralogy of Brazil and in mining engineering. Several of his students are now among the most active and efficient workers on the geology of the country.

The present bibliography is chiefly an author's list arranged alphabetically. When there are several titles credited to one author, they are arranged chronologically. 


\section{BIBLIOGRAPHY}

ABREU E LIMA: See Lima.

ACAUA, BENEDICTO MARQUES DA SILVA: Relatorio dirigido ao Governo Imperial em 15 de Abril, de 1847, pelo Inspector Geral dos terrenos diamantinos da Provincia da Bahia. .Revista do Instituto Historico, 1847. IX, 2a edição, 227-260. Rio de Janeiro, 1869. Parte segunda: da descripção dos terrenos diamantinos, 247-260. Extract in Diccionario geographico das Minas do Brazil por Francisco Ignacio Ferreira. q. v. 209-217. Rio de Janeiro, 1885.

ACOIOLI DE CERQUEIRA E SILVA, IGNACIO: Corografia Paraense, ou descripção fisica, historica e politica, da provincia do Gram-Pará. $8^{\circ}$. Bahia na typografia do Diario, 1833. Mineralogy, 5-6 and footnote; pororóca, 69-70.

ACCIOLY, JOSE BITTENCOURT: Memoria sobre a viagem ao terreno nitroso. Manuscripto, IV, 222-251. Inst. Hist. e Geogr. Braz. (Serra dos Montes Altos entre Urubú e Caitithe.)

ACKERMANN, EUGEN: Die Gold-Industrie an der Grenze des Staates Para im nördlichen Brasilien. Chemiker-Zeitung, XXV, 25-26. $4^{\circ}$. Cöthen, 1901.

ACURA, PADRE CHRISTOVAL DE: Nvevo desevbrimeinto del rio de las Amazonas. Al qval fre, y se hizo por orden de su Magestad, el año de 1639. $4^{\circ} .46 \mathrm{ff}$. En Madrid, en la Imprenta del Reyno, 1641. Oro f. 26; minas f. 27-28. The original edition is very rare. Translated into French under the following title.

ANUNA, CHRISTOFLE D': Relation de la Rivière des Amazones. Traduite par feu M. de Gomberville sur l'original Espangnol. I, 200 pp.; II, 218 pp. 12. Paris, 1682. Translated into German under the next title.

ACUNA: Bericht von dem Strom derer Amazonen. $8^{\circ}$. Wien, 1729. Transist 3 into English under the following title.

ACUGNA, CHRISTOPHER D': Voyages and discoveries in South America. The first up the River of Amazons to Quito, in Peru, and back again to Brazil, performed at the command of the King of Spain. Done into the English from the originals, being the only accounts of those parts hitherto extant. $8^{\circ}$. London, 1698 . Mines of gold, silver, etc. 81-83; 131-133; 176-169 bis; 175 bis; 176 bis.

ADALBERT OF PRUSSIA, Prince: Travels of His Royal Highness, Prince Adalbert of Prussia, in the south of Europe and in Brazil, with a voyage up the Amazon and the Xingu. Translated by Sir Robert H. Schomburgk and John Edward Taylor. 2 vols., $8^{\circ}$. I, 338; 1I, 337. London, 1849. The Brazilian portion begins in vol. I, 211, and extends to the end of vol. II. It contains notes on the character of the rocks.

AGASSIZ, L.: Recherches sur les poissons fossiles. t. II. Neuchatel. 18331843. Amblypterus olfersi Ag., II, p. 4. On page 303 he says it is of "Zechstein" age. II, p. 40, from marl shales of Ceara. Semionotus spixi Ag., from Brazil. t. II, p. 8. Senionotus bergeri Ag., II, p. 226. On page 304 S. bergeri is put down as "Lias." Aspidorhynchus comptoni Ag., from South America, by Gardner, and from Pernambuco. Ir, p. 139 (to be described). On p. $166, A$. Comptoni is said to be from the "Craie." Rhacolepis latus, $R$. buccalis, $R$ : olfersi (=Amblypterus olfersi). t. IV, p. 293. These are listed, but not described, as from the "Craie du Bresil." Cladocyclus gardneri Ag., noted, not described, from Brazil. V, p. 103. Calamopleurus cylindricus, from "Craie du Bresil." t. V, p. 122, not described. Appendice, p. 134, he mentions Gardner's specimens from the north of Brazil. 
AGASSIZ, LOUIS: On the fossil fishes found by Mr. Gardner in the Province of Ceara, in the north of Brazil. Edinburgh New Phitosophical Journal. XXX, 82-84. $8^{\circ}$. Edinburgh, 1841.

AGASSIZ, LOUIS: Sur quelques poissons fossiles du Brésil (Lettre à M. Élie de Beaumont). Comptes Rendus de l'Académie des Sciences. XVIIT, 10071015. Paris, 1844.

AGASSIZ, IOUIS: On the drift in Brazil, and on decomposed rocks under the drift. (Communicated by Alex. Agassiz.) American Journal of science, $2 d$ series, XL, 389-390. (XC.) New Haven, 1865.

AGASSIz, L.: Conversaçôes scientificas sobre o Amazonas feitas na sala do externato do collegio de Pedro II. durante o mez de Maio de $1866.8^{\circ}, \mathrm{T1}$ pp. Rio de Janeiro, 1866. (Collected by F. Vogeli and translated from French to Portuguese by Ant. José Fernandes dos Reis. I. Formação da bacia do Amazonas, 7 de Maio. II. Regimen dos aguas do Amazonas, 14 de Maio. III. Phenomenos erraticos, 20 de Maio. IV. Vegetação-Indios. 26 de Maio. V. As faunas, etc., 30 de Maio.)

AGASSIZ, L.: Lettre à M. Marcou sur la Géologie de la vallée de l'Amazone, avec des remarques de M. Jules Marcou. Bulletin de la Société Géologique de France, 2me sér. XXIV, 109-111. Paris, 1866. Same in German in Neues Jahrbuch für Mineralogie für 1867. 180-181. Stuttgart.

AGASSIz, IoUIS: Physical History of the Amazon Valley. Atlantic Monthly, 49-60; 159-169. Boston, July and August, 1866. This article forms a chapter of "Geological Sketches," which see.

AGASSIz, L.: Agassiz und seine Begleiter am Amazonas. Das Ausland, XXXIX. No. 19. 439-443. Augsburg, 8 Mai, 1866. (Aus dem Atlantic Monthly.)

AGASSIz, L.: Agassiz fahrt auf dem Amazonas von Monte Alegre nach der Serra von Erreré. Das Ausland, XXXIX, No. 48, 1129-1131. Augsburg, November 27, 1866. (Auf dem Atlantic Monthly.)

AGASSIZ, L.: Report . . - on coal from Candiota. (Letter dated Rio de Janeiro, June 18, 1866, addressed to N. Plant.) It forms part of the report of Pakenham and Plant, pp. 23, q. v. London, 1867.

AGASSIZ, LOUIS: Quelques détails sur m voyage sur l'Amazone. Bulletin de la Société Géologique de France, 2me série, 1866-1867. XX; ${ }^{*} ; 49-50$. Paris, 1867.

AGASSIZ, LOUIS: Geology of the valley of the Amazon. Abstract of lectures before the Lowell Institute, October and November, 1866. Annual of Scientific Discovery . . . for 1866 and 1867, 270-273. $8^{\circ}$. Boston, 1867.

AGASSIZ, I.: Observations géologiques faites dans la Vallée de l'Amazone. (Extrait d'une Lettre a $M$. Elie de Beaumont.) Comptes Rendus de l'Académie des sciences, LXIV, 1269-1270. Paris, 1867.

AGASSIZ, L.: Drift in Brazil. Annual of Scientific Discovery for 1866-1867, pp. 269-270. $8^{\circ}$. Boston, 1867.

AGASSIZ, LOUIS: Geography of Brazil: the river Amazon. (Notes based on his Lowell lectures given in Boston, Oct., 1866.) Annual of Scientific Discovery or Year Book of Facts in Science and Art for 1866 and 1867, 357-358. $8^{\circ}$. Boston, 1867.

AGASSIZ, L., and COUTINHO, Major JOÃO MARTINS DA SIIVA: Sur la Géologie de l'Amazone. Bull. Soc. Géologique de France, $2 \mathrm{me}$ série, XXV, 685-691. Paris, 1868. Separate. $8^{\circ}$. Paris, 1867.

AGASSIZ, I.: Bassin de L'Amazone. (Extrait du voyage de M. le professeur Agassiz.) Bulletin de la Société de Géographie de Genève, VIÎ, 159-196. $8^{\circ}$. Gênève, 1868 .

AGASSIZ, Professor and Mrs. LoUIS: A Journey in Brazil. XIX +540 pages, ill. Boston, Ticknor \& Fields, 1868 (chap. XIII, Physical History of the Amazons, 397-441, and many geological notes.) Review: Quar. Jour. of Science, V, 488-490. London, Oct., 1868, Review: Geol, Magazine, $\mathrm{V}, \mathbf{4 5 6 - 4 5 9}$. London, 1868. 
AGASSIZ, Madame et M. LOUIS: Voyage au Brésil. Traduit de l'anglais par Felix Vogeli. Ouvrage illustré de 54 gravures et contenant 5 cartes. $8^{\circ}$, 532 pp. Paris, 1869.

AGASSIZ, I.: (Upon the geology of the Amazons, quoted from his Journey in Brazil.) Annual of Scientific Discovery for 1871, 243-245. Boston, 1871.

AGASSIZ, LOUIS: On Hartt's Geology and Physical Geography of Brazil. Neues Jahrbuch für Mineralogie, Geologie und Palcontologie, 1871, 62-63. Stuttgart, 1871.

AGASSIZ, LOUIS.: South American expedition. Nature, VI, 216, 229-231, and 270-273. London, May, 1872. (Bears indirectly upon the glaciation of Brazil. Reprinted from the New York Tribune of June 26, 1872.)

AGASSIZ, LOUIS: An abstract of a letter concerning glaciation in South America. American Journal of Science. (3rd ser., IV.) CIV, 135-136. New Haven, 1872.

AGASSIZ, I.: South American observations. (Concerning glaciation, etc.) Popular Science Monthly, I, 505. New York, August, 1872.

AGASSIZ, Madame et M. IOUIS: Voyage au Brésil, abrégé sur la traduction de F. Vogeli par J. Belin de Launay et contenant une carte et 16 gravures. Deuzième edition, $12^{\circ}$. XXIV + 268 pages. Paris, 1874 .

AGASSIZ, IOUIS: Geological sketches; physical history of the valley of the Amazon. Boston, 1886. Second series, pp. 153-229. (Published originally in Atlantic Monthly, July and August, 1866, q. v.) Review of Agassiz's Geological sketches, Boston, 1876, in American Journal of Science, 3d series, XI, 232, New Haven, 1876.

AGASSIZ, ELIZABETH CARY: Louis Agassiz, his life and correspondence. Edited by Elizabeth Cary Agassiz. 2 vols., XIV + 794 pages. $8^{\circ}$. Boston, 1882. Chap. XXI, 624-646, contains references to the geology of Brazil. Review : American Journal of Science, CXXX, 406. New Haven, 1885. Abstracts, etc., Das Ausland, XLIT, 853-857; 877-880. Augsburg, 1869.

AGUIAR, Col. F. M. DE SOUZA: Brazil at the Louisiana Purchase Exposition, St. Louis, 1904. (Illustrated circular, with geologic and mining data and cuts, 160 pp.)

ALBUQUERQUE, ITMA: See Lima.

ALBUQUERQUE, LOURENÇO CAVALCANTE DE: Officio dirigido a $\mathbf{S}$. Ex. - Sr. Conselheiro Barão do Penedo, a respeito do guano na ilha Rata, Fernando de Noronha. Auxiliador da Industria Nacional, No. 2, LI, 40-41. Rio de Janeiro, Fev., 1883.

AICANTARA, PEDRo DE: Documentos relativos ao tremor de terra havido em Pernambuco em 1811, offerecidos ao Instituto Historico e Geographico Brasileiro por Sua Magestade o Imperador. Revista do Inst. Hist., XXIII, 401-406. Rio de Janeiro, 1860.

ALCANTARA, DOM PEDRo D': Tremblement de terre survenu an Bresil le 9 Mai, 1886. Extrait d'une lettre de S. M. a M. Daubrée. Oomptes Rendus de l'Academie des Sciences, CII, 1351-1352. Paris, 1886. Abstract: Revue Scientifique, 2me sér., 4me année. XIV, 764. Paris, 1874.

AICANTARA, DOM PEDRO D': On the earthquake which occurred in Brazil May 9, 1886. Letter to the French Academy of Sciences. Nature, XXXIV, 187-188. London, 1886.

ALENCAR, ARARIPE: v. ARARIPE, T. DE A.

ALINCOURT, IUIZ D': Resultado dos trabalhos e indagações estatisticas da Provincia de Matto Grosso por Luiz d'Alincourt, sargento-mór Engenheiro. (Cuyaba, 1828.) Annaes da Bibliotheca Nacional do Rio de Janeiro, 1877-1878, III, fasciculo No. 1, pp. 68-161; fasciculo 2, pp. 225-278. Rio de Janeiro, 1877. Minas e geologia, 268-278.

ALLEN, J. A.: Notes on the geological character of the country between Chique-Chique, on the Rio de São Francisco and Bahia, Brazil. Hartt's Geology and Physical Geography of Brazil, 309-318. Boston, 1870. 
ALLPORT, s.: On the discovery of some fossil remains near Bahia in South America (with notes on the fossils by John Morris and T. Rupert Jones). Quarterly Journal Geol. Soc., XVI, 263-266. Figures and 4 plates. London, Dec., 1859. Abstract: Neues Jahrbuch für Mineralogie, 1860, 494.

ALMEIDA, FRANCISCo ANTONIO: Manoel Timotheo da Costa. As Montan da Juréa (S. Paulo) o Novo Mundo, VII, 127, from the Commercio de Iguape, Provincia de S. Paulo. New York, Junho, 1877.

AIMEIDA, FRANCISCO ANTONIO DE: Noticia sobre as minas de ferro de Jacupiranguinha. Bases de um projecto de exploração. Memoria apresentada a sua exa. o Sñr. Visconde do Rio Branco, $4^{\circ}, 40$ pp. Rio de Janeiro, 1878.

AIMEIDA, GONCALVES DE: Annonce qu'un gisement d'ossements fossiles vient d'être decouvert au Brêsil, dans la province de Rio Grande do Sul. Comptes Rendus de l'Academie Sciences, CXIV, 378. Paris, 1892.

AIMEIDA, Presidente LUIZ A. FERREIRA DE E OUTROS: Minas de carvão de pedra do Arroio dos Ratos. Revista de Engenharia, VI, 186. Rio de Janeiro, 28 de Agosto, 1884.

ALMEIDA, G. OSORIO DE: Communicação feita sobre a applicação do carvão nacional á tracção em estradas de ferro. Annuario do Estado do Rir Grande do $S u l$ para o anno de 1906, pp. 256-263. Porto Alegre, 1905.

ALMEIDA, G. OZORIO DE: v. GUIGNET, E.

ALTON, E. D': tuber die von den verstorbenen Herrn Sellow aus der Banda Oriental mitgebrachten fossilen Panzerfragmente und die dazu gehörigen Knochen-Utberreste. Abhandlungen der König. Akad. der Wissenschaften $z u$ Berlin. Aus dem Jahre 1833, 369-418. Plates, $4^{\circ}$. Berlin, 1835.

ALVARO, SILVEIRA: v. SILVEIRA, ALVARO.

ALVES, HERMILLO CANDIDO DA COSTA: Estrada de ferro da Victoria para Minas. Relatorio apresentado ao $1.11 \mathrm{~m}$. e Exm. Sr. Conselheiro Thomaz José Coelho de Almeida, etc., pelo engenheiro Hermillo Candido da Costa Alves;' Chêfe da commissão de estudos. $8^{\circ}$. Rio de Janeiro, Typographia Nacional, 1876. Aspecto, geologia e riquezas naturaes, 19-22: peat, chalk, iron in the province, granites, schists, plains of sedimentary rocks:

AMAR, RAPHAEL DE: (Notes upon the richness of gold veins, Minas Geraes.) Neues Jahrbuch für Mineralogie, 1833, p. 547. Stuttgart, 1833.

AMAZONAS, LOURENĢO DA SIIVA ARAUJO E: Diccionario topographico, historico, descriptivo da Comarca do Alto Amazonas. $12^{\circ}$. Recife, 1852. Orographia, 15-16; mineraes, 17-18.

AMBAUER, HENRIQUE SCHUTEL: A provincia do Rio Grande do Sul, descripção e viagens. Revista do Instituto Historico, LI, pt. II, 25-72. Rio de Janeiro, 1888.

AMEGHINO, F.: La antiguedad del hombre en el Plata. II. Dl hombre en la formacion pampeana. (Brazil, 373, 391.) Buenos Aires, 1881.

AMEGHINO, F.: See Gervais, Henri.

AMEGHINo, F.: Las antiguas conexiones del continente Sud-Americano y la fauna eocena Argentina. Revista Argentina de Historia Natural. I, 123125. Buenos Aires, 1891.

AMEGHINO, F.: Determinacion de algunos jalones para la restauracion de las antiguas conexiones del continente Sud-Americano. Revista Argentina de Historia Natural. I, 282-288. Buenos Aires, 1891.

AMERICO, DOS SANTOS: v. SANTOS.

AMMON, LUDW. VON: Devonische Versteinerungen ron Lagoinha in Mato Grosso (Brasilien). Zeitschrift der Gesellschaft für Erdkunde zu Berlin, XXVIII, 352-366. Berlin, 1893. (Appendix to paper of Dr. Vogel, q. v.) Abstract: Neues Jahrbuch für Mineralogie, 1895, II, 454.

ANDERSON, JAMES E.: Report of the U. S. Consul in Rio de Janeiro, 1906. (Cf. Brandenburg, A. Bogus mines, etc.) 
ANDRADA, D': An account of the diamonds of Brazil. Nicholson's Journal of Natural Philosophy, Chemistry and the Arts. I, 24-26. London, April, 1797.

ANDRADA, MARTIM FRANCISCO RIBEIRO DE: Diario de uma viagem mineralogica pela provincia de $S$. Paulo no anno de 1805 . Revista do Instituto Historico do Brazil. IX, 527-548, 2a edição. Rio de Janeiro, 1869 (for 1847). Also in Diccionario geographico das minas do Brazil por F. I. Ferreira, 364-377. Rio de Janeiro, 1885.

ANDRADA, MARTIM FRANOISOO RIBEIRO DE: Jornaes das viagens, pela Capitania de São Paulo, de Martim Francisco de Andrada, estipendiado como inspector das minas e matas, e naturalista da mesma capitania, em 1803 e 1804. Revista do Instituto Historico, XLV, Parte I, 5-47. Rio de Janeiro, 1882. (Many geological notes.)

ANDRADA O SIIVA, JOSE BONIFACIO DE, ANDRADA, MARTIM FRANCISCO RIBEIRO DE: Voyage minéralogique dans les provinces de Saint Paul au Brésil. Article communiqué par M. Menezes Drummond, de Rio de Janeiro. Journal des Voyages, découvertes et navigations modernes, ou Archives gêographiques du, 19me siècle, etc. XXXVI, 69-80; 216-227. Paris, 1827. Foot-note on pp. 69-70: "J'ai parlé dans un de mes précédens articles, cahier du mois de Juin, d'une voyage minéralogique entreprise in 1820 dans la province de Saint Paul au Bresil par mon ami le savant José Bonifacio d'Andrada, ex-ministre de l'empereur Don Pedro, et par son respectable frère. La bienveillance dont ces illustres compatriotes m'honorent m'ayant valu la communication des notes recueillies dans cette excursion scientifique. J'ai cru devoir les rédiger en corps d'articles espérant que nos lectures me sauraient gré de mon travail. M. de $\mathcal{D}$." At p. 227 the article is signed Menezes de Drummond. The same article is published in Bulletin des Sciences Naturelles et de Géologie, XVI, 411-415. $8^{\circ}$. Paris, 1829.

ANDRADA O SILVA, JOSE BONIFACIO DE, O MARTIM FRANCISCO DE ANDRADA: Viagem mineralogica na Provincia de São Paulo. Traduzida em francez pelo Conselheiro Antonio de Menezes Drummond e publicada no Journal des Voyages, XXXVI, 69-80; 216-227. Paris, 1827. Reprinted in Manual de Geologia. Por Nereo Boabee, Rio de Janeiro, 1846, annexo pp. 1-34, and in Diccionario geographico das minas do Brazil por F. I. Ferreira, pp. 341-364. Rio de Janeiro, 1885.

ANKER: [Minerals (Peliom) collected by Pohl.] Taschenbuch tür die gesammte Mineralogie von Leonhard. 17ter Jahrgr. 703-707. Frankfurt a. M. 1823.

ANONYMOUS: Genuine account of the present state of the diamond trade in the dominions of Portugal. By a Lisbon merchant. London, 1785.

ANONYMOUS: Letter from Vienna signed * * * in regard to mineralogical work of Dr. Pohl in Minas Geraes and Goyaz and of Herrn Natterer and Varnhagen in são Paulo. Mineralogisches Taschenbuch für das Jahr, 1823. Von K. C. R. von Leonhard, I, Pt. I, 229-232. $8^{\circ}$. Frankfurt am Main, 1823.

ANONYMOUS: Matrix of the Brazilian diamond. Edinburgh Philosophical Journal, IX, 202. Edinburgh, 1823.

ANONYMOUS: 1825 . See Modern Traveller.

ANONYMOUS: An account of the mines and the Province of Minas Geraes in the Empire of Brazil, including a view of the manner of mining metals and precious stones. By a mining proprietor. The Monthly Magazine, or British Register, London (new series, I), March, 1826. 258-267; April, 1826. 395-404. London, 1826. The original article appears to have been written in Portuguese. Abstract under the title: Notice sur les mines de la province de Minas Geraes dans l'empire du Brésil . . . par un propriétaire. Bulletin des Sciences Naturelles et de Géologie, XII, 374-375. Paris, 1827. Another abstract of the same, XVII, 214-218. Paris, 1829. 
ANONYMOUS: Description de la province de Rio-Janeiro. Nouvelles Annales des Voyages, XLVII, 195-244; $2 \mathrm{e}$ article, XLVIII, 30-69; $3 \mathrm{e}$ article, XLVIII, 175-216. Paris, 1830.

ANONYMOUS: L'art de Vérifier les dates depuis l'année 1770 jusqu' à nos jours. XIII. $8^{\circ}$. Paris, 1832. (Brésil, 1-462. Fossils près de la ville de Rio das Contas, 77-78, quoted from Cazal I, 78.)

ANONYMOUS: Three years in the Pacific, including notices of Brazil, Chile, Bolivia, and Peru. By an officer of the United States Navy. (W. S. W. Ruschenberger?) Philadelphia, 1834. Chap. VIII, 65-71, on the geography, products, and diamond mines of Brazil.

ANONYMOUS: Diamond districts of Brazil. Westminster Review, Oct., 1834. XXI, 297-319. See St. Hilaire.

ANONYMOUS: The gold mines of Brazil. Penny Magazine, No. 553. IX, 441-443. London, Nov. 14, 1840.

ANONYMOUS: Ursprünglich Lagerstätte der Diamanten. Pogg. Annalen der Phys. u. Chemie, LVIII, 474. Leipzig, 1843.

ANONYMOUS: Indice da legislação Portugueza sobre as Minas do Brasil. $2^{\circ}$ Appendix, pp. 1-18 de Geologia Elementar applicada á Agricultura e Industria, etc. Por Nereo Boubée. Rio de Janeiro, 1846. The laws are cited down to the year 1816.

ANONYMOUS: Sur l'exploitation du diamant dans la province de Bahia (Brasil). Annales des Mines, 1852, II, 594.

ANONYMOUS: Découverte de nouvelles mines d'or au Brésil, pres de SaintLouis de Maranham. Nouvelles Annales des Voyages, 6me sér. II, 112-114. Paris, 1855.

ANONYMOUS: Neue Gold-Länder. (Maranhão.) Petermann's Mittheilungen, 1855. 119-120. Gotha, 1855 .

ANONYMOUS: Die Diamantwäscherei in Brasilien u. die Diamantschneiderel in Amsterdam. Das Ausland, No. 51, 1856.

ANONYMOUS: The reefs of Pernambuco. The Nautical Magazine and Naval Chronicle, 345-349. London, July, 1861. Quoted from the Moniteur de la Flotte.

ANONYMOUS: Brazil: (Notes on mines). The Mining and Smelting Magazine, V, 44-45. London, Jan., 1864.

ANONYMOUS: (Agassiz und die erratischen Blöcke in der brasilianischen Provinz Ceará). Globus, IX, 382. Hildburghausen, 1865.

ANONYMOUS: Descobrimento de Minas Geraes. Revista do Instituto Historico, XXIX, Parte I, 5-114. Natureza mineral, 5-22. Rio de Janeiro, 1866.

ANONYMOUS: The Roccas. Mercantile Marine Magazine, XIII, 35-50; 65-80 ; 141-143. London, 1866.

ANONYMOUs: Der Pico do Itatiaiossu in Brasilien, eine Aufgabe für Bergbesteiger. Petermann's Mittheilungen, XVII, 392. Gotha, 1871.

ANONYMOUS: Exploration of Professor Hartt in Brazil. Annual Record of Science and Industry for 1872. Edited by Spencer F. Baird. 157-i58. $8^{\circ}$. New York, 1873.

ANONYMOUS: Commissão Geologica. Diario do Rio, Rio de Janeiro, 7 de Julho de 1877.

ANONYMoUs: A Commissão Geologica do Brazil. Published in " $O$ Vulgarisador," a newspaper in Rio de Janeiro, Brazil, Nov. 3,1877 . Reprinted in o Novo Mundo, an illustrated periodical published in New York. January, 1878, VIII, 18-19.

ANONYMOUS: Rochas calcareas no valle do Parahyba. Extrahido do Jornal do Commercio de 9 de Novembro de 1880. Revista de Engenharia, 1880, II, 206. Rio de Janeiro, 1880.

ANONYMOUS: Os sambaquis (kjokken-moddings) de Santos. Boletim da Socicedade de Geographia de Lisbóa. 2a serie, No. 1, 118-119. Lisboa, 1880. 
ANONYMOUS: Catalogo da Exposição de Historia do Brazil realizada pela Bibliotheca Nacional de Rio de Janeiro a 2 de Dezembro de 1881. 2 vols. $8^{\circ}$. Rio de Janeiro, Typ. G. Leuzinger \& Filhos, 1881 . Vol. II, Classe X. Historia natural, obras geraes, pp. 993-997 ; mineralogia e geologia, 1044 1056.

ANONYMOUS: Estatistica da produccão do ouro na provincia de Minas Geraes no anno de 1879. Annaes da Escola de Minas de Ouro Preto, No. 1, 151-154. Rio de Janeiro, 1881.

ANONYMOUS: Estado actual da extracç̃o do ouro no municipio de Ouro Preto, comparado ao do anno de 1814. (Noticia.) Annaes da Escola de Minas de Ouro Preto, No. 1, 155-163. Rio de Janeiro, 1881.

ANONYMOUS: Diversos horizontes auriferos da provincia de Minas Geraes. Auxiliador da Industria Nacional, Julho 1881, XLIX, 154-158.

ANONYMOUS: Fabrica de ferro de Ypanema. Auxiliador da Industria Nacional, XLIX, 158-159. Rio de Janeiro, Julho .1881. Quoted from the Gazeta de Noticias.

ANONYMOUS: The present state of science in Brazil. Science, I, 211-214. Cambridge, March 30, 1883.

ANONYMOUS: Brazilian minerals. S. Paulo. (Iron, oil, coal.) The Mining Journal, LIII, 317. London, July 14, 1883.

ANONXMOUS: Colleccões paleontologicas. Revista de Engenharia, 28 de Out. de $1883, \mathrm{~V}, 289$. Extrahido do Jornal do Commercio de 12 de Out. de 1883. Rio de Janeiro, 1883.

ANONYMOUS: Collecções palentologicas da extincta Commissão Geologica. Do Jornal do Commercio de Rio de Janeiro. Revista de Engenharia, V, 267-268. Rio de Janeiro, Out. 14, 1883.

ANONYMOUS: The Ouro Preto gold mines of Brazil (Limited), [visit of M. Belloc]. The Mining Journal, LVI, 1059. London, Sept. 11, 1886.

ANONYMOUS: Ouro Preto gold mines of Brazil (Limited). (From the Paris Bourse.) The Mining Journal, LVII, 768. London, June 18, 1887.

ANONYMOUS: Forest and mineral wealth of Brazil. Journal of the Society of Arts, XXXIX, 933-934. London, 1891.

ANONYMOUS (?): Relatorio da Companhia Aurifera de Minas Geraes. Rio de Janeiro, 1 de Julho, 1893.

ANONYMOUS: Brazilian exploration in the Amazon valley. Geographical Journal, I, n. 4, 346-347. London, 1893.

ANONYMOUS: Manganese mining in Brazil. Journal of the Society of Arts, XLVIII, 56. Lonđon, Dec. 1, 1899.

ANONYMOUS: Carbons in Brazil. Journal of the Society of Arts, XLVII, 662-663. London, 1899.

ANONYMOUS: Manganerzgewinnung in Brasilien. (Auszug aus.) Stahl und Eisen, n. 1, 1899, s. 48. Zeitschrift für praktische Geologie, April, 1899 , p. 146 .

ANONYMOUS: Mining in Brazil. Mining Journal, LXX, 1466. London, Dec. 1, 1900.

ANONYMOUS: Mica deposits in São Paulo. Annual report of the director of the Bureau of the American Republics for the year 1900. Pt. II, 220. Washington, 1900.

ANONYMOUS: (New monazite deposits in Bahia.) Annual report of the director of the Bureau of the American Republics for the year 1899. Pt. III, 608. Washington, 1900.

ANONYMOUS: The mining industry (of Brazil). Monthly Bulletin of the Bureau of American Republics, IX, 284286. Washington, 1900.

ANONYMOUS: Mining conditions and mineral resources in Brazil. Engineering and Mining Journal, LXXII, 427-429, 3 ills. $4^{\circ}$. New York, Oct. 5, 1901. Also in Brazilian Mining Review, I, 17-19. Ouro Preto, 1902. 
ANONYMOUS: The Morro Velho gold mine, Brazil. Engineering and Mining Journal, LXXII, 485-489, ill. New York, Oct. 19, 1901. Also in Brazilian Mining Review, I, 6-11. Ouro Preto, July, 1902.

ANONYMOUS: A mineração Rio Grandense. Catalogo da Exposição estadual do Rio Grande de Sul em 1901. 9-23. $4^{\circ}$. Porto Alegre, 1901.

ANONYMOUS: A large manganese discovery in Brazil. The Mining Journal, LXXI, 161. London, Feb., 1901. Abstract: Journal of the Iron and Steel Institute, LIX, 345. London, 1901.

ANONYMOUS: Brazil. A geographical sketch, with special reference to economic conditions and prospects of future development. Published by the International Burenu of the American Republics. $8^{\circ} .233 \mathrm{pp}$. Washington, 1901. Geology, 17-18.

ANONYMOUS: Eisenerze in Brasilien. Zeitschrift für praktische Gcologie, $X, 211,313$. Berlin, 1902.

ANONYMOUS: Brazilian diamonds and carbons. Journal of the Society of Arts, L, 928-930; LI, 22. London, 1902.

ANONYMOUS: Quecksilber in Brasilien. Zeitschrift für praktische Geologie, $\mathrm{X}, 137$. Berlin, 1902.

ANONYMOUS: Manganese ore. First article. Brazilian Mining Review, 1, 44-47. Rio de Janeiro, 1902. (See note under Scott, H. Kilburn.)

ANONYMOUS: The Carboniferous basin of the Amazon. Brazilian Mining Review, I, 48-50. Rio de Janeiro, 1902.

ANONYMOUS: Nota sobre uma jazida de Staurotidas nas visinhanças de Ouro Preto. Annaes da Escola de Minas, No. V, 7-10. Ouro Preto, 1902.

ANONYMOUS: Glimmerlager in Brasilien. Montan-Zeitung für Osterreichungarn, ete. $\mathrm{X}, 482 . \mathrm{Graz}, 1903$.

ANONYMOUS: Flexibility of itacolumite. Nature, LXX, 185. London, June 23, 1904.

ANONYMOUS: Brazil. Extract for the History of the Louisiana Purchase Exposition. $4^{\circ}$. St. Louis, 1904. (Geology, etc., 9-14.)

ANONYMOUS: The iron ore beds of Sabara, Minas. Brazilian Mining Review. I, 207-208. Rio de Janeiro, April, 1904.

ANONYMOUS: Monazite. Engineering and Mining Journal, LXXVII, 638. New York, Oct. 20, 1904.

ANONYMOUS: As minas de ouro nacionaes. Jornal do Commercio. Rio de Janeiro, Dec. 5, 1904.

ANONYMOUS: A remarkable amethyst group. Smithsonian Miscellaneous Collections, I, 218, plate LVI. Washington, 1904.

ANONYMOUS: Glimmer in Brasilien. Zeitschrift für prattische Geologie, XII, 110-111. Berlin, 1904. (Quoted from Mines and Minerals.)

ANONYMOUS: The geographical and geological survey of São Paulo. Science, XXI, 476. New York, March 24, 1905.

ANONYMOUS: Commissão geographica e geologica de São Paulo. Jornal do Commercio. Rio de Janeiro, Jan. 13, 1906. Estado de São Paulo, Jan. $16,1906$.

ANONYMOUS: (Manganese in Brazil in 1905.) The Mineral Industry for 1905 , pp. 436-438, New York, 1906.

ANONYMOUS: Analyses de Carvão nacional. (Rio Grande do Sul.) $A n$ nuario do Estado de Rio Grande do Sul para o anno de 1907. Porto. Alegre, 1906, p. 224.

ANTONIL, ANDR JOÃO: Cultura e opulencia do Brazil por suas drogas e minas, etc. Revista do Archivo Publico Mineiro, anno IV, fasciculo III e IV. Julho a Dezembro de 1899. Terceira parte. Cultura e opulencia do Brazil pelas minas de ouro, pp. 507-548. Bello Horizonte, 1900. The first edition of this work was published at Lisbon in 1711; second edition, Rio de Janeiro, 1839. 
ARARIPE, TRISTAX DE AIENCAR: Cidades petrificadas e inscripcõos lapidares no Brazil. Revista do Instituto Historico, L, parte 1a, 213-295. Many illustrations. Rio de Janeiro, 1887.

ARAUJO e AMAZONAS: See Amazonas.

ARAUJO, M. ALVES DE: Fabrica de ferro de S. Joăo de Ipanema. Extracto do relatorio appresentađo $\boldsymbol{a}$ assembléa geral pelo Ministro e Secretario de Fstado dos Negocios da agricultura, etc. Auxiliador da Industria Nacional, L, 138. Rio de Janeiro, 1882.

ARCHIAC: See D'Archiac.

ARBER, E. A. NEWELL: On the distribution of the Glossopteris flora. Geological Magazine, IX, 346-349. London, Aug., 1902.

ARBER, F. A. NEWELL: Catalogue of the fossil plants of the Glossopteris flora in the department of geology. British Museum (Natural History); being a monograph of the Permo-Carboniferous flora of India and the southern hemisphere. London, 1905. Brazilian fossil plants, pp. XXVI. XXXIII, XL, LXVIII, LXX-LXXIII, 17, 102-103, 108, 111-113, 116-117, 119-120, 147-149, 151, 156-162, 165, 176, 200.

ARDUINI, ALFREDO: The Morro da Mina manganese deposits. Brazilian Mining Review, I, 218-219. Rio de Janeiro, May, 1904.

ARFWEdson, AUG.: Analyse du chrisobêril du Brésil. Annales des Mines, IX, 403. Paris, 1824. Abstract: Bul. des Sci. Nat. et de Géologie, 25. Paris, Sept., 1824. Annals of Philosophy, New Series, VII, 345-347. London, May, 1824.

ARLDT, TH.: Die Grösse der alten Kontinente. Neues Jahrb. f. Min. Geol. u. Pal., 1907, I, 32-44. Stuttgart, Feb., 1907.

ARNOLD, RAIPH: (List of fossils collected by J. C. Branner at Ponta de Pedras, Pernambuco.) Bulletin Geological Society of America, XIII, 47. Rochester, 1902.

ASSIER, ADOLPHE D': L'Eldorado bresilien et la Serra das Esmeraldas. Revue des Deux Mondes, 1864, 2me sér., LII, 323-358. Paris, 1864. Account of the mining regions.

ASTOLPHO DA SILVEIRA: V. SILVEIRA.

AUBERTIN, J. J.: Eleven days' journey in the Province of são Paulo. Letter addressed to His Excellency, the Baron of Piracicaba. Notes on iron. $8^{\circ}$. 40 pp. Bates, London, 1866.

AUBUIsson, D': Grès flexible du Brêsil. Journal des Mines, XXXYIII, 214. Paris, 1815.

AUGE, CLAUDE: Nouveau Larousse Illustre. Dictionnaire universel encyclopédique, II, 226-268. $8^{\circ}$. Paris, n. d. Géographie physique, géologie, etc.

AUGUSTO, FAUSTO: v. SOUZA, A. F.

AVE-LALLEMANT, ROBERT: Reise durch Sủd Brasilien in Jarhre 1858. 2 vols. $8^{\circ}$. Leipzig, 1859. Notes on the physical features of São Paulo, Parana, Sta. Catharina and Rio Grande do Sul. Vol. I, Cap. VII. Die Stein-Kohlengrube bei S. Jeronimo am Arroio dos Ratos, etc. 478-484.

AVE-LALLEMANT, Dr. ROBERT: See Lallemant.

AWDEJEW VON: Ueber das Beryllium und dessen Verbindungen: Chrysoberyll aus Brasilien. Annalen der Physiti und Ohemie. Zweite Reihe. Herausgegeben zu Berlin von J. C. Poggendorff. LVI, 118-119. Leipzig, 1842. Analysis, Annales des Mines, 4 me serie, V, 602. Paris, 1844.

AZAMBUJA, BERNARDO AUGUSTO NASCENTES DE: Descripção topographica do Mappa da Provincia de Santa Catharina organisado na Commissão do Registro Geral e Estatistica das terras publicas e possuidas. $8^{\circ} .25$ pp. e carta. Rio de Janeiro, 1874. Physicail features of Sta. Catharina. 
AZAMBUJA, GRACIANo A. DE: Companhia estrada de ferro e minas de São Jeronymo. [Sobre o carvão de pedra do Rio Grande do Sul.] Annuario do Estado do Rio Grande do Sul, para o anno de 1906, pp. 242-244. Porto Alegre, 1905.

AZAMBUJA, GRACIANO A. DE: Coordenadas geographicas e altitudes no Estado do Rio Grande do Sul. Annuario do Estado do Rio Grande do Sul para o anno de 1907, pp. 37-53. Porto Alegre, 1906.

BABINSKI, HENRI: Rapport sur une visite aux lavras diamantinas, gisements de diamants et du carbon de Lençoes, Palmeiras, San Antonio, Chique-Chique et Mar d'Hespanha (Etat de Bahia) Brésil. Paris, 1897, with 1 map.

BADARIOTTI, Abbe NICOLAs: Disparition possible d'une ville, al Brésil. Le Naturaliste. 24me annee, p. 33. Paris, 1902.

BAENA, ANTONIO LADISLAU MONTEIRO: Ensaio corografico sobre a Provincia do Pará. 589 pp. $8^{\circ}$. Pará, 1839. (Barro, cristąes, ouro, pedras preciosas, sal mineral, tabatinga, etc. 24-32; mountain systems of the Rio Branco and Rio Negro districts, 374-375.)

BAGUET, A.: La Province de Minas Geraes et son école des mines à Ouro Preto. Bulletin de la société de Géographie d'Anvers, VII, 81. Anvers, 1882.

BAGUET, A.: La province de Paraná (Brésil) ses ressources. Quelques mots sur l'émigration. Imp. veuve de Backer, 1885, in- $8^{\circ}, 20$ pages. Extrait du Bulletin de la Société Royale de Géographie d'Anvers, IX, 173, 190. Anvers, 1884.

BALI, JOHN: Notes of a Naturalist in South America. $8^{\circ}$. London, 1887. Some geological notes on pages $303-358$.

BALLOD, CARL: Der Staat Santa Catharina in Süd-Brasilien. InauguralDissertation der Philosophischen Fakultät der Universtät Yena, [etc.] $8^{\circ}$. Stuttgart, 1892, Separatabdruck aus dem Ausland, 1892, 27-31. Geology and physical geography, 1-25.

BALLORE, F. DE MONTESSUS DE: Géosynclinaux et régions à tremblements de terre; esquisse de géographie sismico-géologique. Bulletin de la société Belge de Géologie, XVIII, 243-268. Continent africano-brésilien, 255-25ti. Bruxelles, 1905.

BALLORE, F. DE MONTESSUS DE: Les tremblements de terre. Brazil, 167171. Paris, 1906.

BARBACENA: Observaçós sobre a secca do Ceará. Auxiliador da Industria Nacional, 1877, XLV, 574-578. Rio de Janeiro, 1877. Brief sketch of the general geology, chiefly from Gardner.

BARBIER, E: See Darwin.

BARIL, V. I. (Comte de la Hure): L'Empire du Brésil. Monographie complete de l'empire Sud-Americain. Paris, 1862. Geologie et richesses minerales, 112-117.

BARIL, V. L. (Comte de la Hure): (Notas sobre geologia agricola do Brazil) Auxiliador da Industria Nacional, 1865 . pp. 400-402. Rio de Janeiro. 1865.

BARIL, V. I. (Ie comte de la Hure): Penedos de dioritos do valle do Parahyba do Sul (illustrated). Revista do Instituto Historico, XXIX, 422429. Rio de Janeiro, 1866.

BARKER, DAVID WILSON: The glaciation of Brazil. Nature, XLVIII, 614. London, Oct. 26, 1893.

BARRETO, CHRISTOVAM: Rochas do Brazil. Boletim da Secretaria de Agricultura, etc., do Estado da Bahia, II. No. I. 26-28, Bahia, 1903.

BARROW, JOHN: v. MAITE-BRUN.

BASZANGER, JACQUES: Carbonado. Engineering and Mining Journal, LXXXI, 857. New York, May 5, 1906. 
BATALHA, REIS J.: The United States of Brazil. The Internationl Geography, Chap. XIVI (orography and hydrography, 865-867; geology, 867). Edited by H. R. Mill. New York, 1900.

BATES, HENRY WALTER: The naturalist on the river Amazons; first edition, 2 vols., illustrated. London, 1863. Second edition, 1 vol. London, 1864.

BATES, HENRY WALTER: The naturalist on the river Amazons; a record of adventures, habits of animals, sketches of Brazilian and Indian life, etc. 4th ed. London, John Murray, 1875. Boston, 1875.

BATES, HENRY WALTER: The naturalist on the river Amazons, with memoir of the author. By E. Clodd. Portrait and numerous illustrations. 8vo. LXXXIX + 395 pp. London, 1892. (Several other editions, all containing notes on the geology.)

BATES, H. W.: On the delta of the Amazons. Report Brit. Assoc. Adv. Sci., 1864. Transactions, p. 137. London, 1865.

BAUER, HENRIQUE E.: As minas de ferro do Jacupiranga. Revista de Engenharia, No. 170, IX, 213. Rio de Janeiro, 28 de setembro, 1887.

BAUER, HENRIQUE F.: Mineralogische und petrographische Nachtrichten aus dem Tahle der Ribeira de Iguape in Südbrasillien (mit 1 Kartchen und 2 abbildungen). Berichte d. Naturwiss, Vereines Regensburg. II Heft, IV, 64-8. Neubauer'sche Buchdruckerei, 1890. $\mathbf{8}^{\circ}$. 22-40, 1 map, 2 figs., 1 pl. Regensburg, 1888-'89. III, 1890-'91 ; 25-35, 1892.

BAUER, H. E.: As minas de Yporanga (S. Paulo). Revista de Engenharia, no. 232, XII, 85-87, com carta. Rio de Janeiro, 28 de Abril, 1890.

BAUER, MAX: Edelsteinkunde. Eine allgemeine verständliche Darstellung der Eigenschaften, des Verkommens und der Verwendung der Edelsteine nebst einer Anleitung zur Bestimmung derselben für Mineralogen, Steinschleifer, Juweliere, etc. Brasilien, 180-207; 374-376; 382, 421. $4^{\circ}$. C. H. Tauchnitz. Leipzig, 1896. Translated into English under the title: Precious stones, a nopular account of their character, occurrence and applications, ete. By Prof. Max Bauer. Translated from the German. with additions by L. J. Spencer. $626+\mathrm{XVI}$; illustrated. London, 1904.

BAUER, MAX: Beiträge zur Mineralogie. VII Reihe. Neues Jahrbuch für Mineralogie, etc. 1891. Bd. I, 217-266. Stuttgart, 1891. (Brazilian minerals, 229, 233-234.) . Ibstract: Zeitschrift für Krystallographie und Mineralogie (Groth), XX1 I, 290-293. Leipzig, 1894.

BAUMHAUER, H.: Die Krystillstructur des Anatas. Zeitschrift für Krystallographie und Mineralogie (Groth), XXIV, 555-580. Brasilien, 571-580. Leipzig, 1895.

BAYERN, THERESE PRINZESSIN VON: Meine Reise in den Brasilianischen Tropen. $4^{\circ}$, ill., XVI + 544 pp. Berlin, 1897. Geologic notes, 21, 63, 68, $214,222,227,239,241,251,268,276-7,285,303,337,341,387,400,415$, $440,446-7,458,464$.

BEAUCHAMP, AIPHONSE DE: Historie du Brézil depuis sa découverte en 1500, jusqu'en 1810. 3 vols. Paris, 1815. Mines d'or et de diamantes, III, Livres XLIII et XLIV, 422-476.

BEAUMONT, ELIE DE: จ. BRONGNIART, DUFRENOY ET BEAUMONT.

BEAUMONT, I. ELIE DE: Notice sur les systèmes de montagnes. $12^{\circ}$. Mountain systems in Brazil, t. II, 604; 718-720; 729-733. Paris, 1852.

BEAUMONT, H. D.: A journey to the diamond fields of Minas Geraes and remarks on the Province of Minas Geraes. British Diplomatic and Consular Reports, No. 494. Miscellaneous Series. 3-30. London, Foreign Office, Feb., 1899.

BEAUREPAIRE ROHAN: v. ROHAN.

BECK, RICHARD: Lehre von den Erzlagerstätten. Berlin, 1901. Manganerzlager in Minas Geraes, Brasilien, s. 119-120; Passagem, Minas Geraes, s. 327-329. This work was translated into English by W. H. Weed and was published in New York, 1905, under the title: The nature of ore deposits. Gold, 308-310, 474; manganese, 108-109. 
BECQUEREI, HENRI: Sur les propriêtés magnetiques du fer nickelé de Sainte-Catherine (Brésil). Comptes Rendus de l'Acad. Sci., XCIII, 794797. Paris, 1881. See next title from American Journal of Science, 3d ser., CXXIII, 229-232. New Haven, 1882.

BECQUEREL, HENRI, and SMITH, J. LAWRENCE: On the magnetic properties of a specimen of nickeliferous iron from St. Catarine, as first pointed out by Lawrence Smith; with a note by J. Lawrence Smith. Translated from the French. See Comptes Rendus Acad. Sci., XCIII, 794-797. American Journal of Science, 1882, CXXIII, 229-232. New Haven, 1882.

BELIET, DANIEL: Les mines de manganese au Brésil. Revue Technique, April 25, 1899.

BELLO, JOSAPHAT: Official report on the Minas iron deposits. Brazilian Mining Review, I, 219-220. Rio de Janeiro, May, 1904.

BELLOC, H.: The Ouro Preto gold mines of Brazil, limited. Voyage aux mines de Passagem, Raposas, Espirito-Santo et Borges. 26 pp. Paris, Aug., 1886.

BELMONT, A. De: Mineral resources of Brazil. Mining World, New York, June 2, 1906.

BELT, THOMAS: The glacial period in the southern hemisphere. Quart. Jour. Sci., XIV, 326-353. London, 1877. Also separate, London, 1877.

BELT, THOMAS: The Naturalist in Nicaragua. Second edition, p. 265 . London, 1888. Note on glaciation in Brasil.

BEM, BAITHAZAR FRANCISCO DE: Mineração na Provincia do Rio Grande do Sul, Annexo ao Relatorio do Ministro da Agricultura. $3 \mathrm{pp}$. Rio da Janeiro, 1874.

BENEDEN, FDOUARD VAN: Rapport sommaire sur les résultats d'un voyage au Brésil et à la Plata. Bulletins de l'Academie Royale des Sciences, des Lettres et des Beaux Arts de Belgique. XXXV, 2e sér., 775-792. Bruxelles, 1873.

BENNET, E. DE: Contribution à la flore pliocène de la province de Bahia (Brêsil). Bull. Mus. Hist. Nat., 510-512. Paris, 1905.

BENSAUDE, ALFREDO: O diamante. Revista de Sciencias Naturaes $e$ Sociaes, orgão da Sociedade Carlos Ribeiro. II. no. 8, 159-184. Porto, 1893.

BERG, GEORG: Beiträge zur Kentniss der Goldlagerstätten von Raposos in Brasilien. Zeitschrift für Pralctische Geologie, $\mathrm{X}$, 81-84. Berlin, 1902. Abstract in Transactions of North of England Institute of Mining and Mechanical Engineers, XXV, 764-765. Newcastle-upon-Tyne, 1904.

BERINGER, EMIIIO: Estudos sobre o clima e a mortalidade da Capital de Pernambuco. Extrahido do Annuario da Sociedade Meteorologica de França, XXVI, 1878; traduzido e augmentado pelo Bacharel Manoel Duarte Pereira. Aspecto topographico da Provincia de Pernambuco, pp. 8-18. Quotes from Fournier's résumé of Dombre's unpublished notes, pp. 12-15. Pernambuco, 1891.

BERINGER, EMILE: V. FOURNIER, VICTOR.

BERTHIER, P.: Analyse du fer titané en couche du Brésil, et de quelques autres mineraux du même genre. Annales des Mines, V, 479-494. Paris, 1820.

BERTHIER, P.: Analyse d'une pyrite magnetique du Brésil. Annales des Mines (3me sér.) VII, 531-533. Paris, 1835.

BERTOLIO, ANT.: Di un grasso fossile di Rio (de) Janeiro. Atti della Societd Geologica Residente in Milano, II, 140-141. Milano, 1860 . Review ; Ein fossiles Fett von Rio (de) Janeiro, Neues Jahrbuch, 1861, 183.

BERTRAND, C. EG.: Le schiste bitumineux où charbon humique de Ceara. Travaux et Memoirs de l'Université de Lille. VI, Memoire 21, 97-130. Lille, 1898. 
BERTRAND, C. EG.: Charbons gelosiques et charbons humiques. Comptes Réndus, Congrès Géologique International, 1900. I. Le schiste cretace de Ceará, Brésil, 489-494. Paris, 1901.

BERTRAND, C. EG.: Ce que les coupes minces de charbons de terre nous ont appris sur leur modes de formation. Congrès International des Mines, etc., 1905. Livraison II, Géologie Appliquêe, 349-390. Liége, 1906 (Le schiste du Ceará, 356-7; turfa du Rio Marahú, 365).

BERTRAND, EMrLE: Note sur l'andalousite du Brésil et sur les rubis de Siam. Bull. Soc. Mineral. de France, I, 94-95. Paris, 1878. Abstract: Zeitschrift für Krystallographie und Nineralogie (Groth), III, 641-642. Leipzig, 1879.

BERTRAND, E.: (Anatase de Diamantino, Brésil.) Bull. Soc. Mineral de France, t. II, 30. Paris, 1879. Translation: Mineral Mag. and Jour. Mineral. Soc., III, 198. London, 1879.

BERZELIUS, J.: Undersökning af nägra Mineralier. (Containing analysis of a new mineral found in Brazil, viz. "3. Arseniksyradt jern," 345-356.) Kongliga Vetensliaps-Academiens Handlingar för är 1824, pp. 334-358. $8^{\circ}$. Stockholm, 1824.

BERZELIUS, J.: Observations sur diverses espèces minérales, extraites d'une lettre de M. Berzélius; ' á M. M. Alexandre Brongniart. (Notes on minerals, one of them from Brazil.) Annales des Sciences Naturelles, Paris, 1825, vol. 5, 430-432. $8^{\circ}$. Abstract: Bull. des Sci. Nat. et de Géologie, 341-342. Paris, Nov., 1825.

BERZELIUS, J.: Recherches chimiques sur plusieurs minéraux (Analysis of a new mineral found in Brazil). Abstract: Kong. Vetensk-Acad. Handlingar, 1824, pp. 334-358. Bulletin des Sciences Naturelles et de Géologie. VI, 193-196. $8^{\circ}$. Paris, 1825.

BERZELIUS, J. J.: Analyse des "ouro podre" (faules Gold) von Sud-America. Jahresరericht über die Förtschritte der Chemie und Mineralogie, XV, 205. 1836.

BESCHOREN, M.: Zur Geographie der Provinz Rio Grande do Sul. Zeitschrift der Gesellschaft für Erdkunde zu Berlin, XIII, 417-431. Berlin, 1878.

BESCHOREN, M.: Das Waldgebiet des oberen Rio Uruguay in der brasilianischen Provinz São Pedro do Rio Grande do Sul. Zeitschrift der Gesellschaft für Erdlcunde zu Berlin, XV, 195-210. Berlin, 1880.

BESCHOREN, MAX.: Beiträge zur nähern Kentniss der brasilianiscben Provinz São Pedro do Rio Grande do Sul. Reisen und Beobachtungen während der Jahre 1875-1887. Ergänzunsheft No. 96 zu Petermann's Mittheilungen; physical features with map. 91 pp. $4^{\circ}$. Gotha. 1889.

BIBRA, Dr. FRHR. GRUST. v.: Reise in Südamerika, 1er Band. Mannheim, 1854 (Geology about Rio de Janeiro, 116-119).

BIGG-WITHER, T. P.: The valley of the Tibagy. Jour. Roy. Geog. Soc., XLVI, 263-277. London, 1876. Abstract: Proc. Roy. Geog. Soc., XX, 455469. London, 1875-' 6 .

BIGG-WITHER, THOMAS P.: Pioneering in South Brazil. Three years of forest and prairie life in the Province of Parana. 2 vols., with map and illustrations. London, 1878. Vol. II, part IV, chaps. II and III, 213-227, on the diamond regions of Parand.

BILAO, OLAVO: Tremores de terra no Brazil. Almanach Popular Brazileiro para o anno de 1907. pp. 225-250. Pelotas, etc., 1906.

BILTON, W.: See Lund.

BIRKINBINE, JOHN: (Iron ores of Brazil.) Sixteenth Ann. Rept. U. S. Geol. Survey, 1894-'5. Part. III, 67-69. Washington, 1895.

BIRKINBINE, JOHN: (Manganese in Brazil.) Nineteenth Ann. Rept. U. S. Geol. Survey, pt. VI, 107-108. Washington, 1898.

BLAKE, CHARLES CARTER: Past life in South America. The Geologist, 1862, 323-330. London, 1862. 
BLAKE, C. CARTER: On human remains from a bone cave in Brazil. Journal of the Anthropological society of London, II, CCLXV-CCLXVII. $8^{\circ}$. London, 1864.

BLAKE, G. S.: See Imperial Institute.

BLOT, G. R.: Rapport presenté en Decembre 1891 au Conseil d'administration de la Cie. Générale des Diamants du Brésil (Cannavieiras). Paris, 1892.

BLUM, J. REINHARD: Taschenbuch der Edelsteinkunde für Mineralogen, Techniker, Kuenstler und Liebhaber der Edelsteins. (Diamonds, 106-132; Topaz, 157-165 ; Emerald, 165-176, etc.) Stuttgart, 1832.

BLUM, J. R.: Taschenbuch der Edelsteinkunde für Mineralogen, Techniker und Juwliere. Dritte verbesserte Auflage. (Notes on the various precious stones found in Brazil.) $342 \mathrm{pp}$. $8^{\circ}$. Leipzig, 1887.

BOAS, J. E. V.: Om em fossil Zebra-Form fro Brasiliens Campos. Med. et Tillaeg om to Arter af Slaegten Hippidion. Det Kongelige Danske. Videriskabernes Selskabs S7kifter. .Naturvidenskabelig og Mathematisli Afdeling. I, No. 5, pp. 307-332, and 2 plates. $4^{\circ}$. Kjöbenhavn, 1881. (Vol. 1880-1885.)

BOCOURT: Description de quelques sauriens nouveaux originaires de l'Amérique Méridionale. Bulletin des Nouvelles Archives du Muséum, tome VI. Paris, 1870. Anolis Williamsi from Bahia, Brazil, 16-17.

BOETTGER, OSKAR: Die Tertiärfauna von Pebas am oberen Marañon. Jahrbuch d. K. K. Geol. Reichsanstalt, 1878, XXVIII, 3 Heft., 485-504, 2 plates. Abstract: Neues Jahrb. für Min., G. $u$ P., 1879, 219-220. Stuttgart, 1879 .

BOHM, C. RICHARD: Monazite sand. Engineering and Mining Journal, LXXXI, 842. New York, May 5, 1906. Abstract from Chemische Industrie, Jan., $1906.2-7$.

BOLSTAD, I.: Om Brasiliens Järnindustrie samt järn-och manganmalmer. (Iron ore in Brazil.) Bihang till Jern-Kontorets Annaler, 1903, sjette Häflet, 230-240. Stockholm, 1903. Abstract: Journal of the Iron and Steel Institute, 1903, II, 536. London, 1904.

BOM-FIM: $\nabla$. ESPINDOLA.

BONIFACIO, JOSE: $\nabla$. ANDRADA E SIIVA.

BORCHERT, A.: Das Alter der Parana-Stufe. Centralblatt für Mineralogie, Geologie, ete. 1901, No. 4, 111-113. Stuttgart, 1901.

BOSSI, EL. C. BARTHOLOMł: Viage pintoresco por los Rios Paraná, Paraguay, Sn. Lorenzo, Cuyabà y el Arino tributario del grande Amazonas, con la descripcion de la Provincia de Mato Grosse en bajo su aspecto físico, geografico, mineralogico, etc. Paris, 1863. Chart and many illustrations. Few notes on gold, diamonds, etc. $109,120,121$.

BOTELHO, LEONIDAS DAMAZIo: Analyses feitas no laboratorio de Docimasia da Escola de Minas de Ouro Preto. Annaes da Escola de Minias de Ouro Preto, No. 3. Rio de Janeiro, 1884. Calcarios, p. 232 e 234; manganez, 235.

BOTELHO, LEONIDAs DAMAzIo: Analyses feitas no Laboratorio de Docimasia da Escola de Minas de Ouro Preto. Annaes da Escola de Minas de Ouro Preto. 1885, No. 4, 201-208.

BOUBEE, NEREO: Geologia Elementar applicada a Agricultura e Industria, com hum diccionario dos termos geologicos, ou Manual de Geologia. Traduzido da quarta edição. Rio de Janeiro, na Typographia Nacional, 1846. (Contains three appendices, I, 1-55, by José Bonifacio de Andrada e Silva e Martim Francisco Ribeiro de Andrada, d'Eschwege, Van Lede, and Gardner: see those names.)

BoUt, A.: Correspondance minéralogique de MM. A. Brongniart, V. Monteiro, A. Boué, L. Woltz et Wagner. (Abstract of Vienna letter, signed ${ }^{*} *^{*} *$ in, Leonhard's Mineralogisches Taschenbuch, 1823, 229-232. Mention of collection of Pohl from Minas and Goyaz and of Natterer from S. Paulo. Bulletin des sciences Naturelles et de Qéologie, II. 233-225. $8^{\circ}$. Paris, 1824. 
BOUt, AMI: Résumé des progrès des sciences géologiques pendant l'année 1823. Bull. Soc. Géol. de France, t. V. Brésil, 416-418. Paris, 1834.

Poú: Découverte au Brésil, province de Minas-Geraes, d'un gisement de diamants dans le quarzite ou l'itacolumite. (Extrait de trois lettres, l'une a M. de Wegmann et les deux autres a M. Michelin.) Bull. Soc. Géol., 1re série, 1842, 1843, XIV, 232-233. Paris, 1842.

BOURGAdE LA DARDYe, E. DE.: Le Paraguay. (Aperçu géologique, chap. II, 23-32; 112-113.) 12 . Paris, 1889.

BOURGADE LA DARDYs, $\mathbf{E}$. DE: Paraguay; the land and the people, natural wealth and commercial capabilities. English edition edited by E. G. Ravenstein. $8^{\circ}$. London, 1892. A geological survey, 8-13; 143-150.

BoUssingaULT, J. B.: Sur le gisement du platine (Extrait d'une lettro adressée à $\mathbf{M}$. de Humboldt et lettre de $\mathbf{M}$. Boussingault à $\mathbf{M}$. de Hum. boldt). Annales de Chimie et de Physique, XXXII, 204-212. Paris, Juin, 1826. Also in German in Annalen der Physil von Poggendorff, VII, 515-525. Leipzig, 1826. (Itaberite und platine in Minas Geraes.) Abstract: Bul. des Sci. Nat. et de Géologie. 168-170. Paris, Nov., 1826.

BoUTAN, E.: Diamant. Encyclopédie Chimique, publiếe sous la direction de M. Fremy. Tome II, 2me partie. $8^{\circ}$. Paris, 1886. Chap. IV, 122-150 : gisement de diamants aux mines du Brésil.

BOVET, A. DE: Analyses feitas nos laboratorios de chemica e docimasia da Escola de Minas de Ouro Preto. IV. $1^{\circ}$. Analyses do phosphato de cal da Ilha Rata, Fernando de Noronha. Annaes da Escola de Minas de Ouro Preto 1883. no. 2, 141. Revista de Engenharia, V, 272. Rio de Janeiro, 14 de Out., 1883.

BOVET, A. DE: A Industria mineral na Provincia de Minas Geraes. 1a parte. Ouro e ferro. Annaes da Escola de Minas de Ouro Preto, 1883, no. 2, 25-99. Revista de Engenharia, 28 de Fev. de 1884, VI, 41-42; 14 de Março de 1884 , VI, $50 ; 28$ de Março VI, 65-66; 14 de Abril de 1884, VI, 75-76; 28 de Abril de 1884, VI, 91-92; 14 de Maio de 1884, VI, 101-102; 14 de Junho de 1884, VI, 128; 28 de Junho de 1884, VI, 138-139; 28 de Julho de 1884, VI, $158-160 ; 14$ de Agosto de 1884, VI, 172-173; 14 de Setembro de 1884, VI, 189-191; 28 de Setembro de 1884, VI, 204-205; 14 de Out. de 1884, VI, 216-217; 28 de Out. de 1884, VI, 227-229; 14 de Nov. de 1884, VI, 241-242. Rio de Janeiro, 1884.

BOVET, A. DE: L'industrie minérale dans la Province de Minas-Geraes. An nales de Mines. 8a série, III, 85-122; 123-208. Paris, 1883. Abstract: Transactions of North of England Institute of Mining and Mechanical Engineers, XIII, 21. Newcastle-upon-Tyne, 1884. Abstract, upon "the Iron ores and iron industry of Minas Geraes," Journal of the Iron and Steel Institute, 1883, II, 789-793. London, 1883.

BOVET, A. DE: Gold in the province of Minas Geraes, Brazil. Engineering and Mining Journal, pp. 248-249. New York, Oct. 20, 1883.

BOVET, A. DE: Diamond mining in the province of Minas Geraes, Brazil, I. Engineering and Mining Journal, Oct. 6, 1883, pp. 216-217; II, Oct. 13, 1883, p. 233. New York, 1883.

BOVET, A. DE: L'exploitation du diamant au Brésil. La Nature, 1884, XII année (2me série) 166-170, ill. Paris, 1884.

BOVET, A. DE: Note sur une exploitation de diamants près de Diamantina, province de Minas Geraes, Brésil. Annales des Mines, 8me série, V, 465504. Paris, 1884.

BOVET, A. DE: Note sur l'état actual de la legislation des mines au Brésil. Annales des Mines, 8me série, VII, 435-453. Paris, 1885.

BRACKENRIDGE, H. M.: Voyage to South America, performed by order of the American government in the years 1817 and 1818 in the Frigate "Congress." By H. M. Brackenridge, Esq., Secretary to the Mission. 2 vols., $8^{\circ}$. London, 1820 . Memoranda on the mining industries. Vol. I, 145-154; note on landslips, I, 104. 
BRAGA, ALBERTO VIEIRA: Estrangeiros illustres no Brazil. Almanach Popular Brazileiro para o anno 1904, 243-246 (C. F. Hartt); 246-251 (H. Gorceix). Pelotas, Porto Alegre e Rio Grande. $8^{\circ}$. 1903.

BRAGA, ALBERTO VIERA: Estrangeiros illustres no Brazil. Almanach Popular Brazileiro para o anno 1905, p. 207 (Frederico Draenert) ; p. 210 (Eugenio Hussak) ; p. 213 (Arthur Thire). Pelotas, Porto Alegre, Rjo Grande. $8^{\circ} .1904$.

BRANDÃO: See Mello Brandão, $P$. de.

BRANDENBURG, ARMANDO: Brazil and its mineral industry. Mining Magazine, XIII, 560-566. New York, July, 1906.

BRANDENBURG, ARMANDO: Mining in Brazil. Engineering and Mining Journal, New York, Aug., 1906, p. 34; Matto Grosso, Brazil, New York, Sept. 1, 1906.

BRANNER, J. C.: Rock inseriptions in Brazil. American Naturalist, XVIII, 1189-1192. Philadelphia, 1884. Separates contain also pp. 1192a-1199b.

BRANNER, J. C.: Note on flexible sandstone. American Naturalist, XVIII, 927. Philadelphia, Sept., 1884.

BRANNER, J. C.: The pororoca, or bore, of the Amazon. Science, Nov., 1884, IV, 488-492, ill. Also separate, with additional notes, ill., 12 pp., $8^{\circ}$. Boston, 1885. German translation: Die Pororóca oder der Zeitstrom am Amazonas. Das Ausland, LVIII, 11-15. Stuttgart u. Müncheh, 1885. Zeitschrift für Schule Geographie, VI, 201, 1885.

BRANNER, J. C.: Inscripções em rochedos do Brazil. (Translation from the English by Dr. João Baptista Regueira Costa.) Art. 3, p. 1, da Revista do Instituto Arch. e Geogr. Pernambucano, 12 pp., $8^{\circ}, 111$. Pernambuco, 1885. Republished in no. 60, 249-261. Recife, 1904.

BRANNER, J. C.: Geographical and geological exploration in Brazil. American Naturalist, Aug., 1886, XX, 687-690. Philadelphia, 1886.

BRANNER, J. C.: Notes on the fauna of the Islands of Fernando de Noronlai. American Naturalist, XXII, 861-871. $8^{\circ}$. Philadelphia, Oct., 1888.

BRANNER, J. C.: Cretaceous and Tertiary geology of the Sergipe-Alagôn Basin of Brazil. Trans. Amer. Phil. Soc., XVI, 1889, 369-434, Plates I-IV, $4^{\circ}$. Philadelphia, 1889. Abstract: Amer. Jour. Sci., 1889, CXXXVII, 412. Abstract: Neues Jahrb. für Mineral., 1892, I, 134-139. (Referate.) Review: See Choffat, P. Abstract: Petermann's Mittheilungen, XXXIX. Literaturbericht, 71-72. Gotha, 1890.

BRANNER, J. C.: The age and correlation of the Mesozoic rocks of the Sergipe-Alagôas basin of Brazil. Proc. Amer. Assoc. Adv. Sci., 1888, XXXVII, 187-188, $8^{\circ}$. Salem, 1889.

BRANNER, J. C.: The geology of Fernando de Noronha. Part I. [For Part II, see Williams, G. H.] American Journal of Science, Vol. XXXVII, 145-161. New Haven, 1889. (Portuguese edition published by the Inst. Arch. e Geogr. Pernambucano. Recife, 1890.) Abstract: Petermani's Mittheilungen, XXXIX, Literaturbericht, 71. Gotha, 1890.

BRANNER, J. C.: The æolian sandstone of Fernando de Noronha. American Journal of Science, XXXIX, 247-257. New Haven, April, 1890. Abstract: N. Jahrb. f. Mineral., 1892, I, 320-321. (Referate.)

BRANNER, J. C.: Geologia de Fernando de Noronha. Revista do Instituto Archeologico e Geographico Pernambucano, 20-22. Pernambuco, Aprll, 1890. (Abstract of the preceding article.)

BRANNER, J. C.: The "poror6ca," or bore, of the Amazon. Popular Science Monthly, Dec., 1890, XXXVIII, 208-215. New York, 1890.

BRaNNER, J. C.: Os grés eblios de Fernando de Noronha. Revista do Instit. Arch. e Geogr. Pernambucano, No. 44, 161-171, ill., $8^{\circ}$. Pernambuco, 1893.

BRANNER, J. C.: A geologia cretacea e terciaria da bacia do Brazil SergipeAlagôas. Traducção de Garcia Muniz, 170 pp., $8^{\circ}$. Aracajú, 1893. (Portuguese ed. of the "Cretaceous and Tertiary geology of the Sergipe-Alagoas basin without the illustrations). 
BRANNER, J. C.: The supposed glaciation of Brazil. Journal of Geology, 1893, Vol. I, 753-772, ill., $8^{\circ}$. Chicago, 1893 . Review by A. R. Wallace. Nature, XLVIII, 589-590. London, 1893. Abstract: Petermans's Mittheilungen, XL, Literaturbericht, 127. Gotha, 1894.

BRANNER. J. C.: Abstract of F. Katzer's "Oldest fossiliferous beds of the Amazon region." Journal of Geology, 1896, IV, 975-976. Chicago, 1896.

BRANNER, J. C.: A supposta glaciação do Brazil. Revista Brazileira, 1896, VI, 49-55; 106-113. Rio de Janeiro, 1896.

BRANNER, J. C.: Decomposition of rocks in Brazil. Bull. Geol. Soc. America, VII, 255-314. Illustrated. Rochester, 1895-'96. Review by O. A. (Derby). Revista Brazileira, VII, 139-140. Rio de Janeiro, 1896. Review Revista do Rio Grande do Norte, Nov. and Dec., 1899. Natal, 1899. Abstract: Neues Jahrb. $f$. Mineral., 1897, II, 79-80. (Referate.)

BRANNER, J. C.: The decomposition of rocks in Brazil. (Editorial.) Journal of Geology, 1896, IV, 630-631. Chicago, 1896.

BRANNER, J. C.: Review of Katzer's "Devonian fauna of the Rio Maecurú." Published in the Boletim do Museu Paraense. Journal of Geology, 1897, V, 757-758. Chicago, 1897.

BRANNER, J. C.: Review of the "Unpublished reports of the Commissão Geologica do Brazil." Published in the Boletim do Musen Paraense. Journal of Geology, 1897, V, 756-757. Chicago, 1897.

BRANNER, J. O., and GILMAN, C. E.: The stone reef at the mouth of the Rio Grande do Norte. American Geologist, Dec., 1899, XXIV, 342-344. Minneapolis, 1899.

BRANNER, J. C.: Note upon "The Upper Siluria fauna of the Rio Trombetas. State of Para, of Brazil, and Devonian mollusca of the State of Para, Brazil." By John M. Clarke. Journal of Geology, 1899, VII, 813-814. Chicago, 1899.

BRANNER, J. C.: The recent ascent of Itambé. National Geographic Magazine, $1899, \mathrm{x}, 183$. Washington, 1899.

BRANNER, J. O.: The manganese deposits of Bahia and Minas, Brazil. Trans. Amer. Inst. Min. Eng., 1899, XXIX, 756-770. New York, 1900. Excerpts in the 21st Ann. Rept. of the U. S. Geol. Survey, part VI, 149-151. Washington, 1901. Abstract: Journal of the Iron and Steel Institute, LVII, 282. London, 1900.

BranNer, J. C.: The São Paulo sheet of the topographic sulvey of São Paulo, Brazil. Journal of Geology, 1899, VII, 788-789. Chicago, 1899.

BRANNER, J. C.: Ants as geologic agents in the tropics. Journal of Geologw, VIII, 151-153. Chicago, 1900.

BRANNER, J. C.: Two characteristic geologic sections on the northeast const of Brazil. Proceedings of the Washington Academy of Science, 1900, II. 185-201, ill. Washington, 1900. Abstract: Annales de Géographie, 288-289. Paris, Sept. 15, 1902.

BRANNER, J. C., and GILMAN, C. E.: O recife de pedra na foz do Rio Grande do Norte. (Translated by Dr. Alfredo de Carvalho.) Revista do Rio Grande do Norte, Nos. 1 and 2, 267-271. Natal, 1900.

BRANNER, J. C.: O mappa topographico do Estado de São Paulo. Revista Brazileira, XIX, 111-114. Rio de Janeiro, 1899. Republished in the Cidade de Santos, Santos, Brazil, Jan. 10, 1900.

BRANNER, J. C.: Diamonds in Brazil. Mineral Industry for 1899, 221-222. New York, 1900.

BRANNER, J. C.: Gold in Brazil. Mineral Industry for 1899. VIII, 281. New York, 1900.

BRANNER, J. C.: Os recifes de grés do Rio Formoso. Revista do Instituto Archeologico e Geographico Pernambucano, N. 54, anno XXXVIII, 131-136. Map and illus: $8^{\circ}$. Pernambuco, 1901.

BRANNER, J. C.: South America. The new volume of the Encyclopedia Britannica, 10th edition, 365-370. London, 1902. 
BRANNER, J. C.: The oil-bearing shales of the coast of Brazil. Trans. Amer. Inst. Min. Eng., XXX, 537-554, $\mathbf{8}^{\circ}$, ill. New York, 1901. Abstract: Eng. and Min. Jour., Sept. 15, 1900, LXX, 308-309. New York, 1900. Zeitschrift fïr Praltische Geologie, Dez., 1900, VIII, 392-393. Abstract: Mining Journal, Oct. 20, 1900, LXX, p. 1273. London (1900). Abstract: Neues Jahrbuch für Min. Geol. u. Pal., 1901, Bd. II, 267-368. Referate. Abstract: Monthly Bulletin of the Bureau of the American Republics, IX, 994-995. Washington, 1900. Abstract: Journal of the Iron and steel Institute, LVIII, 457-458. London, 1900.

BRANNER, J. C.: Geology of the northeast coast of Brazil. Bull. Geol. Soc. Amer., 1901, vol. XIII, 41-98, ill., $8^{\circ}$. Rochester, 1902. Review : Peterniann's Mittheilungen, Literaturbericht, XIII, Heft XII, 212. 1905.

BRANNER, J. C.: The occurrence of fossil remains of mammals in the interior of the States of Pernambuco and Alagôas, Brazil. American Journal of Science, 4th ser., XIII, 133-137 (one map and one plate). New Haven, Feb., 1902. Abstract: Nenes Jahrbuch für Mineralogie, II, 148. Stuttgart, 1904.

BRANNER, J. C.: Is the peak of Fernando de Noronha a volcanic plug like that of Mont Pelé? Anierican Journal of Science, Dec., 1901, GLXVI, 442444. New Haven, 1903. Two views reproduced in American Geologist, XXXIII, 320. Minneapolis, May, 1904. Abstract: Petermann's Mittheilungen, L, 148. Gotha, 1904.

BRANNER, J. C.: Da occurrencia de restos de mammiferos fosseis no interior dos Estados de Pernambuco e Alagôas. Traduzido do American Journal of Science, XIII, por Alfredo de Carvalho. Revista do Instituto Archeologico e Geographico Pernambucano, X, 219-224. Pernambuco, 1903.

BRANNER, J. C.: Geologia de Pernambuco. Traduzido do Bulletin of the Geological Society of America, XIII, por Alfredo de Carvalho. Revista do Instituto Archeologico e Geographico Pernambucano, $\mathrm{X}$, no. 58, 381-402. Recife, 1903; X, no. 59, 507-525. Recife, 1903. Review: Petermann's Mittheilungen, 1905, Literaturbericht, 212. Gotha, 1905.

BRANNER, J. C.: Review of Katzer's "Grundzüge der Geologie des unteren Amazonasgebietes." Journal of Geology, XII, 278. Chicago, 1904.

BRANNER, J. C.: The stone reefs of Brazil, their geological and geographical relations, with a chapter on the coral reefs. Bulletin of the Museum of Comparative Zoology at Harvard Oollege, XLIV. Geological series, VII, $8^{\circ}$. 285 pp. (99 plates and 104 cuts). Cambridge, Mass., May, 1904. Notice: Nature, LXX, 334. London, Aug. 4, 1904. Reviews by Carvalho, Revista do Instituto Archeologico e Geographico Pernambucano. No. 60, 301-304, Recife, 1904. Derby, Science, May 12, 1905. XXI, 738-740. J. S. F., Geographical Journal, XXV, 665-666. London, June, 1905. Sievers, Petermann's Mittheilungen, 212-213. Gotha, 1905.

BRANNER, J. C.: Stone reefs on the northeast coast of Brazil. Bulletin of the Geological Society of America, XVI, 1-11. Rochester, 1905. (Illustrated.) Review: Scottish Geographical Magazine, XXI, 273. May, 1905.

BRANNER, J. C.: Extract from letter to Dr. Paula Pessôa on Notilops brama, Jornal do Commercio, Rio de Janeiro, April 7, 1905.

BRANNER, J. C.: Translation of Derby's article upon the geology of the diamond and carbonado washings of Bahia, Brazil. Economic Geology, I; 134-142. Nor.-Dec., 1905.

BRANNER, J. O.: Notas para a geologia do Rio Grande do Norte. (Traduzidas pelo Dr. Alfredo de Carvalho.) Revista do Instituto Historico e Geographico do Rio Grande do Norte, II, no. 2, 239-248. Natal, 1904.

BRANNER, JOHN C.: Geologia elementar preparada com referencia especial aos estudantes brazileiros. $8^{\circ} .305$ pp. 156 cuts. Rio de Janeiro, Laemmert \& C., 1906.

BRANNER, J. C.: The new geological survey of Brazil. science, XXV, 510513. New York, March 29, 1907.

BRANNER, J. C.: See Jordan, D. S. 
BRASIL: v. POMPEO DE SOUZA BRASIL.

BRAZIIIAN EMPIRE, The: The Quarterly Review, CVIII. No. 216. London, 1860. Gold and Diamond mines, pp. 328-332. Salt and coal deposits, 338, foot-note.

BRAZILIAN GOID MINES (at Descoberto): (Supplement to) The Mining Journal, Railway and Commercial Gazette, LIV, 701-702. London, June 14, 1884.

BRAZILIAN GOLD MINES (LIMITED), THE: The Mining Journal, Railway and Commercial Gazette, LVII, 812-813. London, July 2, 1887.

BRAZILIAN GOLD MINING COMPANIES: Supplement to the Mining Jounal, March 3, 1872, XLII, 228; March 16, 1872, XIII, 251-252. London, 1872.

BRAZILIAN MINING REVIEW: See Medrado, A.

BRAZILIAN REVIEW: Gold mining in Brazil. Rio de Janeiro, 1898. Brazilian Bulletin, I, 100-102. São Paulo, 1898.

BREITHAUPT, A.: Neue Specifische Gewiche von Mineralien und anderen Körpern. Journal für Pralctische Chemie, III. Leipzig, 1834. (Brasilien, 275.) Abstract: Neues Jahrb. für Mineral., 1835 (Brasilien), 474.

BREUIL: Sur des recherches de mines au Brésil. (Extrait d'une lettre adressée à M. le Ministre des Affaires ctrangères.) Annales de Mines, 5me serie, VII, 628-629. Paris, 1855.

BREWSTER, Sir DAVID: On the distribution of coloring matter and on certain peculiarities in the structure and properties of the Brasilian topaz. Transactions of the Cambridge Philosophical Society, II, pt. I, 1-10. Cambridge, 1827. Abstract: Bulletin des Sci. Nat. et de Géologie, No. 2, 234-236. Paris, Fev., 1827.

BREWSTER, DAVID: Brasil. The Edinburgh Encyclopadia, IV, pt. 2, Art. on Brazil. $4^{\circ}$. Edinburgh, 1830 (Gold and Diamonds, 423).

BRIGIDO, VIRGILIO: Mineral resources of Ceará. Brazilian Mining Review, I, 93-94. Rio de Janeiro, July, 1903.

BRITO, Col. PEDRO TORQUATO XAVIER, DE: Memoria historica e geographica da Ilha da Trinidade, organisada e dedicada ao Illm. e Exm. Sr. Barão da Ponte Ribeiro. Revista do Inst. Hist., XL, parte II, 249-275 (maps, views and sections). Rio de Janeiro, 1877.

BRITTO, ALFREDO: Relatorio apresentado ao Exm. Sr. Conselheiro Luiz Vianna, Governador do Estado, acerca dos estudos que fez na Europa sobre as areias do Prado, por incumbencia do Governo. Bahia, 1898. $54 \mathrm{pp}$., with appendices, making 91 pages in all.

BROCKHAUS, BRASILIEN: Brockhaus Konversations-Lexikon, III. OberflächengestaItung, p. 395 ; Bergbau, p. 399. Leipzig, 1901.

BRONGNIART: Note sur la présence de l'anatase dans les mines de diamant du Brésil. Annales des Sciences Naturelles, IX, 223-224. Paris, Oct., 1826. Abstract: Bull. des Sci. Nat. et de Geol., No. 4, 439. Paris, Avril, 1827.

BRONGNIART, ADOLPHE: Notice sur le Psaronius brasiliensis. Bul. de la Societe Botanique de France, XIX, 3-10. $8^{\circ}$. Paris, 1872. [NoTE.-The specimen was sent Brongniart from the Museo Nacional, but it was bought in Germany by the Brazilian government. It is not known where it came from. Brogniart says it is quite different from the European specimens. He thinks it is from Piauhy. A specimen is figured in Von Martius' "Palms from Piauhy." See Unger. See Zeiller and Salm-Laubach.]

BRONGNIART, ALEXANDRE, DUFRENOY, BEAUMONT, ELIE DE: Rapport sur un mémoire de M. Alcide d'Orbigny, intiulé: Considérations générales sur la géologie de l'Amerique méridionale, pp. 11.42 of the appendix to d'Orbigny's Voyage dans l'Amérique Méridionale. Géologie, III, 3me partie. $4^{\circ}$. Paris, 1842. Extrait: Comptes Rendus de l'Acad. Sci., XVII, 379-417. Paris, 1843. A foot-note says this report is also printed in the Nouvelles Annales du Muséum d'Histoire Naturelle, III, 84 et seq. Report on geology. See Cordier, this bibliography. 
BROUSSEAU, GEORGFS: Les Richesses de la Guyane Française et de l'ancien contesté Franco-Brésilien. Onze ans d'exploration, ill., and map. 248 + VIII. Paris, Sociêtê d'êditions scientifiques, 1901. 4me partie. L'ancien contesté franco-brésilien, $185 \mathrm{et} s e q$. Constitution géologique générale, 193 et seq. L'or, etc., 217-234. Houille, 235-236.

BROWN, C. BARRINGTON, and IIDSTONE, WILLIAM: Fifteen thousand miles on the Amazon and its tributaries, with maps and wood engravings. London, $1878\left(520 \mathrm{pp}, 8^{\circ}\right)$. Contains many notes upon the geology.

BROWN, C. BARRINGTON: On the Tertiary deposits on the Solimões and Javary Rivers in Brazil, with an appendix by $\mathrm{R}$. Etheridge. Quart. Jour. Geol. Soc., XXXV, 76-88. One plate. London, 1879. Abstract: The Geological Record, 1879, 134-135. London, 1887.

BROWN, C. BARRINGTON: On the ancient river deposit of the Amazon. Quart. Jour. Geol. Society, XXXV, 763-777, map and figures. London. 1879.

BROWN, CHARLES B., and SAWKINS, J. G.: Reports on the physical, descriptive, and economic geology of British Guiana. Published by order of the Lords Commissioners of Her Majesty's 'Treasury. 297 pp., ills., and maps. London, printed for Her Majesty's Stationary Office, 1875. Geology on the Brazilian frontier.

BUCH, LEOPOLD VON: Ueber die Juraformation auf der Erdflüche. Monatsberichte der Konigl. Preuss. Akademie der Wissenschaften zu Berlin, 1852, 662-680. Hierzu Taf. LIV. Gesammelte Schriften, IV, 960-976. (Taf. LIV.) Berlin, 1885.

BUCHANAN, M. A.: v. "CHALLENGER."

BtrCKING, HUGO: Ueber die Krystallformen des Epidot. Zeitschrift für Krystallographie und Mineralogie (Groth), II. Epidot aus Brasilien, 404-405. Leipzig, 1878.

BUENO, FRANCISCO ANTONIO PIMENTA: Memoria justificativa dos planos apresentados ao Governo Imperial para o prolongamento da Estrada de ferro de São Paulo. $4^{\circ}$. Rio de Janeiro, 1876. (Descripção geral do terreno, 13; riquezas naturaes, 17-18. Nota basalto, diorito, pedra calcarea, gres, ferro, agatha, etc.

BURAT, AMEDEE: Géologie appliquée, ou traité de la recherche et de l'exploitation des minéraux utiles. $8^{\circ}$. Paris, Langlois et Leclerq. $n$. d. (Brésil, 199-203.)

BURLAMAQUI, FREDERICO LEOPOLDO CESAR: Parecer sobre um manuscripto do Sr. Manoel Lourenço de Souza, Engenheiro de minas do Pará. Bibliotheca Guanabarense. Trabalhos da Sociedade Vellosiana, 11-12. $4^{\circ}$. Dated Rio de Janeiro, 22 de março, 1851 (?).

BURLAMAQUE, F.: (Notas sobre mineraes no Rio de Janeiro.) Bibliotheca Guanabarense. Trabalhos da Soc. Vellosiana, p. 32. Dated Museu, Rio de Janeiro, 15 de julho, 1851 (?).

BURLAMAQUE, F. L. C.: (Noticia de mineraes de varias localidades do Brazil.) Bibliotheca Guanabarense. Trabalhos da Soc. Vellosiana. Secção de Mineralogia e Geologia, 149-160. Rio de Janeiro, Julho, 1854.

BURLAMAQUE, FREDERICO IEOPOIDO CESAR: Noticia ácerea dos animaes de raças extinctas, descobertos em varios pontos do Brazil. Dated Rio, 9 de Junho de 1855. Bibliotheca Guanabarense. Trabalhos da Sociedade Vellosiana. 1855, pp. 1-21 (2a parte). Rio de Janeiro, 1855 (?).

BURLAMAQUI, F. L. C.: Noticia acerca de alguns mineraes e rochas de varias Provincias do Brasil, recebidos no Museu Nacional durante o anno de 1855 (dated Sept., 1856). Revista Brazileira, II, 73-104. Rio de Janeiro, 1859. Geological sections of the coal fields of Southern Brazil. A foot-note says this article is a continuation of others published in the "Guanabara."

BURLAMAQUE, F.: Noticia sobre alguns mineraes e rochas de varias provincias do Brazil, recebidas no Museu Nacional durante os annos de 1856 , 1857 e 1858. Revista Brazileira, II, 241-265. Map of Sta. Catharina coal fields. Rio de Janeiro, 1856-'58. 
BURLAMAQUI, F. L. C., e OUTROS: (Parecer sobre a subvenção pretendida pelo Sr. Conde de la Hure.) O Auxiliador da Industria Nacional, pp. 5-7. Rio de Janeiro, 1866.

BURMEISTER, HERMANN: Reise nach Brasilien, durch die Provinzen von Rio de Janeiro und Minas Geraes. Mit besonderer Rücksicht auf die Naturgeschichte der Gold und Diamantendistricte. Mit einer Karte. Berlin, 1853. Notes on the geology; 184-185, 178, 212, 226, 307, 359, 395, 407, 473, 481, 518, 534, etc., etc. Review: Zeitschrift für Allgemeine Erdkunde, II, 469-481. Berlin, 1854.

BURMEISTER, H.: Description physique de la Republique Argentine d'après des observations personelles et etrangères. Traduit de l'Allemand avec le concours de E. Daireaux. Paris, Librairie F. Savy, 1876, 3 vols. $8^{\circ}$. Tome II, 393, note upon the theory of the glaciation of Brazil.

BURTON, R. F.: Genaures über die neuentdeckten Kohlenflötze Brasiliens. Das Ausland, XXXIX, No. 35, 840. Augsburg, Aug. 28, 1866.

BURTON, Captain RICHARD F.: Explorations of the Highlands of the (sic) Brazil, with a full account of the gold and diamond mines. Also canoeing down 1,500 miles of the great river São Francisco from Sabara to the sea. 2 vols. $8^{\circ}$. London, 1869 . Contains many observations on the geology of the region traversed. Review: Das Ausland, XLII, 351-358; 373-380. Augsburg, 1869.

BURTON, R. F.: The primordial inhabitants of Minas Geraes, and the occupations of the present inhabitants. Journal of the Anthropological Institute of Great Britain and Ireland, II, 407-423. London, 1873. Abstract: Revue Scientifique de la France, XII, 853-855. Paris, 1873. (Captain Burton says at the beginning of this paper that it is translated from the meritorious labors of Henrique Gerber.)

BUSCALIONI, IUIGI: Une escursione botanica nell' Amazzonia. Bulletino della Societá Geográfica Italiana, Ser. IV, II, $8^{\circ}$. Roma, 1901. La regione dei Tocantins del punto di vista climatologico e geologico, 439444 ; Campos, teoria relativa alla loro orogine, 444-455.

CABRAI, FREDERICO A. DE VASCONCELIOS A. PEREIRA: Memoria geologica sobre os terrenos de Curral-Alto e Serro do Roque, na Provincia de S. Pedro do Sul, $8^{\circ}$, XIV, 162 pp., geologic map and colored geologic sections. Porto Alegre, 1851 .

CALB, G.: See Jannasch, $P$.

CALDCLEUGH, ALEXANDER: Travels in South America during the years 1819-'20-21; containing an account of the present state of Brazil, Buenos Ayres, and Chile. Two vols. $8^{\circ}$. London, 1825 , vol. I, XII + 373; vol. II, VIII + 380. (Maps; notes on the geology.) Review of part of the geology of Minas in Zeitschrift für Mineralogie von Leonhard. Jahrgang, 1827, II Band, 497-500. Frankfurt a. M., 1827.

CAIDCLEUGH, A.: Reisen in Süd-Amerika während der Jahre 1819, 1820, 1821; enthaltend eine Schilderung des gegenwärtigen Zustandes v. Brasilien, Buenos-Ayres u. Chile. Weimar, 1826. German translation of the preceding title.

CALDCLEUGH, A.: Voyages dans l'Amerique meridionale pendant les années 1819,20 et 21 . Etat présent du Brésil, de Buenos-Ayres et du Chili. Analyse de cet ouvrage. Nowvelles Annales des Voyages, XXXI, 225-246; 2e article XXXI, 369-385. Paris, 1826.

CAIDOLEUGH, AIEXANDER: On the geology of Rio de Janeiro. Transactions of the Geological Society of London, $2 \mathrm{~d}$ ser., II, 69-72. London, 1829. Abstract: Bulletin des Sci. Nat. et de Géol., 46-47. Paris, Jan., 1827.

CAIDERWood, W.: (Coal at Taubate, São Paulo.) Note in the Ohemiker Zeitung, XVIII, 89. Cöthen, Jan. 20, 1894. Abstract: Journal of the Iron and Steel Institute, XLV, 451-452. London, 1894.

CALIXTO, BENEDICTO: Algumas notas e informações sobre a situação dos sambaquis de Itanhaen e de Santos. Revista do M useu Paulista, VI, 490518. São Paulo, 1904. 
CALOGERAS, J. P.: (Meteorite of Santa Catharina.) Jornal do Commercio, Rio de Janeiro, May 29, 1892.

CALOGERAS, J. P.: Le fer nickele de Sainte-Catherine. Revue Scientifque, t. L, 591-594. Paris, 1892. Abstract: N. Jahrb. für Mineral., 1893. I, 480. Referate.

CALOGERAS, J. P.: Minerios de ferro. Jornal do Commercio. Rio de Janeiro, Oct. 9, 1893.

CALOGERAS, J. P.: Gisements diamantiferes d'Agua Suja. Revista Industrial de Minas Geraes. Anno II, 15 de Janeiro de 1895, 5-8; 15 de Fev. de 1895, 33-37. Revue Universelle des Mines et de la Metallurgie, No. 29, 1895.

CALOGERAS, J. P.: A fabrica de ferro de S. João de Ipanema. Revista Brazileira, Jan. de 1895, I, 83-95; Fevereiro de 1895, I, 179-186; Marco de 1895, 290-200; Abril de 1895, II, 90-100; Maio de 1895, 212-227. Río de Janeiro, 1895. Abstract: The Brazilian Bulletin, I, no. 3, 132-134. São Paulo, Dec., 1898.

CALOGERAS, J. P.: As minas de ouro nacionaes. Jornal do Commercio. Rio de Janeiro, Dec. 3, 1904.

CALOGERAs, JOÃo PANDIÁ: As minas do Brazil e sua legislação. 2 vols. $8^{\circ}$. Rio de Janeiro, 1905. Camara dos Deputados. Paracer apresentado a commissão especial das minas pelo relator. I, XV $+479 \mathrm{pp} ; \mathrm{II}, 627 \mathrm{pp}$. Several chapters on the geology of economic minerals. Part of one chapter translated and published under the title "Gem mining in Brazil," in 'T'le Mining World, XXIV, 101. Chicago, Jan. 27, 1906.

CALOJERAS (sic), J. P.: Contribution a l'etude des exploitations de diamants au Brésil. Note sur les gisements diamantifères d'Agua Suja. Revue Universelle des Mines, de la Métallurgie, XXIX, 1-21. Liege et Paris, 1895.

CAMARA, ANT. ALVES: O manganez no Estado da Bahia. Revista io Instituto Polytechnico Brazileiro. Vol. - , pp. - . Separada, Rio de Janeiro. $1906,8^{\circ}, 28$ pp. Same in English, Brazilian Engineering and Mining Review, II, 37-40. Rio de Janeiro, 1906.

CAMARA, JOSE DE SA BITTENCOURT: Memoria Mineralogica do Terreno Mineiro da Comarca de Sabará offerecida ao Illustrissimo e Excellentissimo Senhor José Bonifacio de Andrada e Silva, Ministro (etc.) por un seu collega. Revista do Archivo Publico Mineiro, anno II, fasc. 4, Out. a Dez. de 1897, 599-609. Ouro Preto, 1897.

CAMPOS, IUIZ F. GONZAGA DE: Relatorio dos trabalhos de pesquiza e preliminares de exploracão, que mandou executar na Logôa Dourada a Empreza de Mineração do Municipio de S. José d'El-Rei. Rio de Janeiro, 1881. 19 pages.

CAMPOS, L. F. GONZAGA DE: These de concurso para uma das vagas do curso de minas da Escola Polytechnica. Rio de Janeiro, 1881.

CAMPOS, LUIZ F. GONZAGA DE: Empreza de Mineração no Municipio de Apiahy (S. Paulo) sob a firma social Saraiva, Rezende viliott \& C. Relatorio dos trabalhos effectuados no decurso dos mezes de Junho de 1882 a Janeiro de 1883. Rio de Janeiro, Reprint, São Paulo, 1900, 59 pages, with 3 maps.

CAMPOS, LUIZ F. GONZAGA DE: Note on the locality of the Santa Catharina meteorite. Revista do Observatorio do Rio de Janeiro. Abstract: Amer. Jour. Sci., 3d series, XXXVI (CXXXVI), 157-158. New Haven, 1888. Abstract (of abstract in Amer. Jour. Sci.): Neues Jahrb. für Mineral., 1889, II, 281 . Referate.

CAMPOS, L. F. GONZAGA DE: Nota sobre a localidade do ferro nativo de Santa Catharina. Meteoritos Brasileiros; extrahida da Revista do $\mathrm{Ob}$ servatorio. III, n. 5, 65-68. Rio de Janeiro, 1888. Abstract: Neues Jahrb. für Mineral., 1891, I, 243. (Referate.) 
CAMPOS, IUTz GONZAGA DE: Minas de carvão do Tubarão [Santa Catharina ], $49 \mathrm{pp}$. com mappas e perfis, $4^{\circ}$, Rio de Janeiro, Imprensa Nacional, 1890. F' a segunda parte do Relatorio apresentado ao Exm, Sr. General Francisco Glicerio, Ministro da Agricultura, etc., pelos Engenheiros F. Hostilio de Moraes Rego, Luiz Gonzaga de Campos e João Caldeira de Alvarenga Messeder, pp. 27-76, com mappas e perfis. Translated into English under the title: The coal beds of Tubarão, Santa Catherina. Brazilian Mining Review, I, 102-105; 168-173. Rio de Janeiro, 1903.

CAMPOS, I. F. GONZAGA DE: Jazidas diamantiferas de Agua Suja, Bagagem, Estado de Minas Geraes. Rio de Janeiro, 1891. 52 pages, with two maps. The same article in English: The Agua Suja diamond deposits. Brazilian Mining Review, I, 88-92; 158-161; 175-176; 185-186; 198-202. Rio de Janeiro, July, 1903, to April, 1904. Also in Mining Journal, Railway and Commercial Gazette, 23-30. London, July 9, 1904.

CAMPOS, L. F. GONZAGA DE: Estrada de Ferro de Araraquara, Prolonga mento de Ribeirãosinho a S. José do Rio Pardo, Estudos Geraes. São Paulo, 1901, 52 pages.

CAMPOS, GONZAGA DE: Reconhecimento geologico e estudo de substancias bituminosas na bacia do Rio Marahá, Estado da Bahia. $21 \mathrm{pp} .4^{\circ}$, with geological map. São Paulo, Nov., 1902.

OAMPOS, L. F. GONZAGA DE: The lignite deposits of Maraht, Bahla. Brazilian Mining Review, I, 124-129; 134-137. Rio de Janeiro, 1903. ('Translation of preceding article.)

OAMPOS, L. F. GONZAGA DE: Reconhecimento da zona comprehendida entre Baurú e Itapura. S. Paulo, 1905. $4^{\circ}, 40$ pp., maps. (Notes on the geology.)

CAMPOS, I. F. GONZAGA DE: The coal deposits of Sant Antonio da Boa Vista. Brazilian Engineering and Mining Review. III, pp. 20-21. Rio, Feb., 1906.

CAMPOS, L. F. GONZAGA De: Relatorio sobre o Rio Tieté. S. Paulo, 1905.

CANSTATT, OSCAR: Geologische Beschaffenhelt des Colonialgebiets um $\mathbf{s}$. Cruz. Globus, XXIX, 331-333. Braunschweig, 1876.

CANSTATT: Die Muschelberge an der süd-brasilianischen Küste. Das Ausland. n. 14, 278-279. Stuttgart, April 3, 1876.

CANSTATT, OSCAR: Brasilien, Land u. Leute. XVI, $8^{\circ} .456$ pp. Mit 13 Holzschnitten und 13 Steindrucktafeln zum Theil nach Origin alaufnahmen von Dr. R. Canstatt. Berlin, 1877. (Notes on physical features, chap. I ; minerals, chap. VI, 126-138.)

CANSTATT, OSKAR: Das Republikanische Brasilien in Vergangenheit und Gegenwart. Nach den neusten amtlichen Quellen und auf Grund eigener Anschauung von Oskar Canstatt, frührem kaiserlich-brasilianischen Koloniendirektor. Mit 66 Abbildungen, 2 karten, etc. Leipzig, 1899. Geologischer Aufbau, 50-54. Bergbau, 170-185.

CAPANEMA, G. S. DE: Observações sobre a origem do barro vermelho na provincia do Rio de Janeiro. Bibliotheca Guanabarense. Trabalhos da Sociedade Vellosiana, 12-16. Read May 9th, 1851 (?). Rio de Janeiro, 1854. Also in Diccionario Geographico das Minas do Brazil, por F. I. Ferreira, 305-309. Rio de Janeiro, 1885.

CAPANEMA, G. S. DE: Quaes as tradições ou vestigios que nos levem a certeza de ter havido terremotos no Brazil. (Dated 1854.) Revista do Instit. Hist., XXII, 135-159. Rio de Janeiro, 1859.

CAPANEMA, GUITHERME s. DE: Trabalhos da Commissão scientifica de Exploração. Parte I, introduç̧ão. Secç̃̃o geologica, pp. CXX-CXIIII. Rio de Janeiro, 1862.

CAPANEMA, G. S. DE: Decomposição dos penedos no Brazil. Lição popular, proferida em 25 de Junho. $8^{\circ}, 32$ pp. Rio de Janeiro, Typ. Perseverança, 1866. 
CAPANEMA, G. S. DE: (Sobre a carta de Dr. Ladislau Netto a respeito das rochas do Corcovado.) Diario Official do Imperio do Brasil, p. 2, Cols. 1-2. Rio de Janeiro, Nov. 27, 1868.

CAPANEMA, G. S.: Apontamentos geologicos (ao correr da penna). $12^{\circ}$ $80 \mathrm{pp}$. Rio de Janeiro, Typ. do Diario do Rio de Janeiro, 1868. A series of letters first published in the Diario do Rio de Janeiro, Nov. 16, 17, 20, 28 and Dec. 4, 5, 1868. The parts so published include the first six chapters of the book.

CAPANEMA, G. S. DE: Die Sambaquis oder Muschelhügel Brasiliens. Petermann's Mittheilungen, XX, 228-230. Gotha, 1874. Abstract: The Geological Record, 1874, 162. London, 1875.

CAPANEMA, G. S. DE: Os sambaquis. Ensaios de sciencia por diversos amadores, pp. 81-89. Rio de Janeiro, Marco, 1876.

CAPANEMA, GUILHERME S. DE: Apreço de sciencia brazileira. Gazeta de Noticias. Rio de Janeiro, 14 Junho de 1877.

CAPANEMA, G. S. DE: As seccas do Ceara. Revista do Instituto Polytechnico, $\mathrm{X}, 1-12$. 10th paper. Rio de Janeiro, 1878. On page 3 he says the drouths of Ceara have existed since Tertiary, and probably began in Cretaceous times.

CAPANEMA, G. S. DE: Acerca dos depositos em ilhas vizinhas da de Fernando de Noronha. Revista Agricola do Imperial Instituto Fluminense de Agricultura, XII, 61-62. Rio de Janeíro, 2 de Junho, 1881.

CAPANEMA, G. S. DE: Um caso de critica scientifica. Commercio de São Paulo, July, 27-28, 1902.

CAPANEMA: A secea do Norte. Boletim da Secretaria de Agricultura, ete, do Estado da Bahia, III, 216-240. Bahia, 1904.

CARAPEBUS, JOSEPH DE: Notice sur les ressources minérales du Brésil. Par Joseph de Carapebus. Elêve de l'ccole des mines. $8^{\circ}, 54$ pages et une carte minéralogique du Brésil. Paris, 1884.

CARdoso, J. PEDro: Relatorio (da Commissão Geogr. e Geologica do Estado de S. Paulo), Anno de 1906. S. Paulo, 1907, $8^{\circ}$, ill., 20 pp.

CARGOE, SPENCER: Notes on the chlorination vat process as applicable to the auriferous concentrates of the Santa Anna main lode, Brazil. Transactions of the Institution of Mining and Metallurgy, VIII, 121-135. London, $1899-1900$.

CARNEIRO, ANT. JOAQUIM DE SOUZA: Pelo São Francisco. Estructura geologica e mineraes. Labor, I, No. 3, 21-23. Bahia, Junho, 1905.

CARRUTHERS, W.: On the plant remains from the Brazilian coal beds, with remarks on the genus Flemingites. Geological Magazine, VI, 151-155. Plates V-VI. London, 1869. Separate, with Plant's paper, pp. 5-10, 2 plates. Abstract: Neues Jahrb. f. Mineral., 1870, 663-664. Abstract: The Popular Science Review, VIII, 311. London, 1869.

CARUS, J. VIOTOR: See Darwin.

CARVALHO, ALFREDO DE: Review of Branner's Bibliography of the geology, mineralogy and paleontology of Brazil. Revista do Instituto Archeologico e Geographico Pernambucano, No. 60, 286-288. Recife, 1904.

CARVALHO, A. DE: See Branner, Darwin, Tollenare, Williamson.

CARVALHO, ALFREDO DE: Minas de ouro e prata no Brasil oriental. Explorações hollondezas, no seculo, XVII. Revist. Inst. Arch. e Geographico Pernambucano, XI, 769-782. Pernambuco, 1906.

CARVAIHO, JOSE CARLOS DE: O meteorito de Bendegó. Revista soc. de Geographica do Rio de Janeiro, 1887, III, 120-123.

CARVAIHO, JOSE CARLOS DE: O meteorito de Benđegó. Revista de Engenharia, n. 164, IX, 138-139. Rio de Janeiro, 28 de Junho, 1887. 
CARVALHO, JOSE CARLOS DE: Rapport présenté au Ministère de l'Agriculture, du Commerce et des Travaux Publics et a la Societé de Géographie de Rio de Janeiro sur le deplacement et le transport due metéorite de Bendégo de l'interieur de la provence de Bahia au Museu National. Rio de Janeiro, Imprimerie Nationale, 1888 , pp. 68 , with map and 4 plates. In same volume a Portuguese version of the same report, with 64 pages.

CASTELNAU, FRANCIS DE: Expedition dans les parties centrales de l'Amérique du Sud. de Rio de Janeiro à Lima, et de Lima au Parḱ, exécutée par ordre du gouvernement français pendant les années 1843 à 1847 sous la direction de Francis de Castelnau. Histoire du voyage, six vols. Paris, $8^{\circ}$, tome 1, 1850, 467; II, 1850,485 ; III, 1851, 483; IV, 1851, 467; V, 1851,480 .

CASTELNAU, FRANCIS DE, et D'OSERY, EUGine: Expédition dans les parties centrales de l'Amérique du Sud, de Rio de Janeiro a Lima, et de Lima au Pará, exécutée par ordre du gouvernement Français pendant les années 1843 a 1847 , sous la direction de F. de Castelnau. Quatrième Partie. Itineraires et coupe géologique à travers, le continent de l'Amérique du Sud, de Rio de Janeiro a Lima, sur les observations de F. de Castelnau et Eugène d'Osery. (Les cartes gravees par Bouffard.) Paris, 1852.

CASTELNAU, FRANCIS DE: Sur l'exploitation du diamant dans la province de Babia, Brésil. Annales des Mines, 5me série, II, 594. Paris, 1852.

CASTELNAU, FRANCIS DE, et D'OSERY, EUGÉNE: Expédition dans les parties centrales de l'Amérique du Sud, de Rio de Janeiro à Lima, et de Lima au Pará, executée par ordre du gouvernement français pendant les annees 1843 a 1847 , sous la direction de F. Castelnan Cinquième partie, Paris, 1853. Géographie des parties centrales de l'Amerique du Sud, et particulierement de l'equateur au Tropique du Capricorne, d'apres les documents recueillis pendant l'expédition exécutée par ordre du gouvernement français pendant les années 1843 a 1847 , de Rio de Janeiro a Lima, et de Lima au Pará, sous la direction du Comte Françis de Castalnau, et rédigée par lui sur ses observations et sur celles du Vicomte Eugène d'Osery. (Les cartes gravèes par Bouffard.) Folio. 1854.

CASTELNAU: Découverte d'un diamant intermédiaire entre le Grand-Mogol et Ie Régent. Société Philomatique de Paris. Extraits des Procès-Verbaux des séances pendant l'année, 1853. 44. Paris, 1853.

CASTELNAU, M. le Comte: Les diamans dans Matto Grosso pres de Diamantino. Journal des Debats, p. 2, Col. 4. Paris, Aug. 10, 1845. Diamantes no Matta Grosso, Traducção desta carta. Revista do Instituto Historico, $1845,567-568,2 \mathrm{~d}$ ed. Rio de Janeiro, 1866.

CASTEINAU: See Gervais, Paul.

CASTRO SARMENTO: $\nabla$. SARMENTO, JACOB DE 0.

CATÃO GOMES JARDIM: V. JARDIM.

CAVALCANTI, JOSE POMPEU DE A: Chorographia da Provincia do Ceará, $8^{\circ}, 323$ pages. Rio de Janeiro, 1888. (Alturas 9-10; géologia 33-75.)

CAVALCANTI DE ALBUQUERQUE: V. ALBUQUERQUE.

CAYEUX, I.: Structure d'une Itacolumnite tres flexible du Brésil. Bull. Société Philomatique, 1905, 1-2. Paris, 1905.

CAZAL, MANOEI AYRES DE: Corografia Brazilica, ou relação historicogeographica do Reino do Brazil. Composta e dedicada a Sua Magestade Fidelissima por hum presbitero secular do Gram Priorado do Crato. 2 vols. Rio de Janeiro, 1817. The fossils mentioned in vol. I, 76-77, are the remains of large vertebrates found in excavating a watering place for cattle in the termo da villa de Rio de Contas, Provincia de Babia. D'Orbigny says this is the first mention of fossils in Brazil. List of known minerals, $\mathrm{I}, \mathbf{5 7}, 361$.

CHABRILIAC, F.: Sur quelques poissons fossiles de la province de Ceara, au Brésil. Extrait d'une lettre a Elie de Beaumont. Comptes Rendus de l'Acad. Sci., XVIII, 1007. Paris, 1844. 
CHAIX, P.: Derniers travaux sur le bassin de l'Amazone. Mémoires de la Société de Géographie de Genève, VII, 5-26 et charte. Genève, 1868.

CHALLENGER: Tizard. T. H., Moseley, H. N., Buchanan, M. A., Murray, John. Narrative of the cruise of H. M. S. "Challenger," with a general account of the scientific results of the expedition. Narrative, I, First Part. $4^{\circ}$. London, 1885. Fernando de Noronha, 210-214; dredging along the coast of Brazil, 214-227; 237.

CHALMERS, G.: Water in the Morro Velho mine. Engineering and Mining Journal, LXXV, 624. New York, April 25, 1903.

CHANCOURTOIS,M. DE: Sur la question de fer natif. Bulletin de la société Géologique de France. Sêr. 3, V, 110-111. Paris, 1877. Abstract: Geological Record for 1878, 269. London, 1882.

CHANDLESS, W.: Notes on the rivers Arinos, Juruema, and Tapajos. Journal Royal Geographical Society, XXXII, 268-280, map. London, 1862.

CHANDLESS, W.: Ascent of the River Puras. Journal Royal Geographical Society, XXXVI, 86-118. Map. London, 1866.

CHANDLESS, W.: Notes on the River Aquiry, the principal affluent of the River Purûs. Journal Royal Geographical Society, XXXVI, 119-128. Map. London, 1866. Abstract: Proceedings of the Roy. Geog. Soc., 1866-7, XI, 100-102.

CHANDLESS, W.: Apontamento sobre o Rio Aquiry, affluente do Rio Purus. Annexo (lettra n) ao Relatorio do Ministro de Agricultura, ete. Rio de Janeiro, 1866, pp. 1-6.

CHANDLESS, W.: Der Purus, ein Nehenfluss des Amazonen-Stromes. Petermann's Mittheilungen, 1867, 257-266. (3 Karten.) Gotha, 1867.

CHANDLESS, W.: Notes of a journey up the River Jurua. Journal Royal Geographical Society, XXXIX, 296-311. Map. London, 1869.

CHANDLESS, W.: Notes on the rivers Maue-assti, Abacaxis, and Canuma, Amazons. Journal Royal Geographical Society, XL, 419-432. Map. London, 1870.

CHANDLESS, W.: Exploração dos rios Juruk, Maué-assú e Abacaxis. Annexo (lettra $n$ ) ao Relatorio do Ministro de Agricultura, etc. Rio de Janeiro, 1870, pp. 1-16.

CHATRIAN, NTCoLAs: Sur le gisement de diamants de Salobro, Bresil. Bull. Soc. Française de Minéralogie, IX, 302-305. Paris, 1886.

CHATRIAN, N.: $\nabla$. JACOBS, H.

CHEVALIER, E.: Voyage autour du monde exécuté pendant les années 1836 et 1837 sur la corvette "La Bonite," etc. Géologie et Minéralogie, par M. E. Chevalier. Brésil, 17-45. Paris, 1844.

CHOFFAT, P.: Nouvelles publications sur les dépôts mésozoiques du Brésil. Revista de Sciencias Naturaes e Sociaes. Orgao dos Trabalhos da Sociedade Carlos Ribeiro. I, No. 3, 115-121. Porto, 1889.

CHOFfAT, P.: Nouveau mémoire sur les terrains mesozoiques. (Review of Branner's Cretaceous and Tertiary geology of the Sergipe-Alagôas basin of Brazil.) Bulletin de la société Belge de Géologie. III, 429-430. Bruxelles, 1889.

CHURCH, GEORGE EARL: The route to Bolivia via the river Amazon. A report to the governments of Bolivia and Brazil. $8^{\circ}$. 216 pp. Waterow \& Sons, London, 1877. Some notes on geology, 186-188.

CHURCH, GEORGE FARI: Argentine gengraphy and the ancient Pampean sea. The Geographical Journal, XII, 386-401. London, Oct., 1898. Also in Report of the 68th Annual Meeting of the British Association for the Advancement of Science, 1898. 924-937. London, 1899.

CHURCH, Col. GEORGE EARL: South America: an outline of its physical geography. The Geographical Journal, XVII, n. 4, 333 et seq. (The part relating to Brazil, 356-358; 370-387; 392-393. London, April, 1901.)

CHURCH, $\boldsymbol{G}$. E.: The Acre territory and the caoutchouc region of southwestern Amazonia. The Geographical Journal. Separate, $17 \mathrm{pp}$. London, 1904. (Physical features.) 
CHURCH, GEORGE E.: Comments upon "Exploration in Bolivia, by H. Hart." Geographical Journal, XXV, 511-513. Mas, 1905. Glaciation in Brazil.

CHURCH, G. E.: See Keller.

CLARAZ, C.: $\nabla$. HEUSSER and CLARAZ.

CLARKE, JOHN M.: As trilobitas do grez de Ereré e Maecurú, Estado do Pará, Brazil. Archivos do Museu Nacional do Rio de Janeiro, IX, 1-58. 2 plates, 2 figs. [Portuguese and English.] Rio de Janeiro, 1896. Abstract: Neues Jahrbuch für Mineralogie, I; 171, 1892.

CLARKE, JOHN M.: A Fauna siluriana superior do Rio Trombetas, Estado do Pará, Brazil. Arch. Mus. Nac. de Janeiro, $\mathrm{X}, 1-48,1$ fig. (Portuguese and English.) Rio de Janeiro, 1899. Review: Neues Jahrb. für Mineralogie, 1901, I, 297.

CLARKE, JOHN M.: Molluscos devonianos do Estado do Pará. Brazil. Arch. Mus. Nac. Rio de Janeiro, X, 49-174, 8 pls. (Portuguese and English.) $4^{\circ}$. Rio de Janeiro, 1899.

CLARKE, JOHN M.: The paleozoic faunas of Para, Brazil. 1.-The Silurian fauna of the Rio Trombetas. 2.-The Devonian mollusca of the State of Pará. Author's English edition, Albany (N. Y.), 1900.

CLARKE, J. M.: Devonic fossils from Brazil. Letter to I. C. White included in the latter's report on the coal measures of South Brazil, pp. 23-27. (In press.) Rio de Janeiro.

OLAUSS, OTTO: Bericht über die Schingú-Expedition im Jahre 1884. Petermann's Mittheilungen, XXXII, 1886. 129-134. Mit Karte 3, Tafeln 7. 32 Band. 1886, 162-171. Mit Karte 3, Tafeln 8. Gotha, 1886.

CLAUSSEN: Sur le gisement des diamants dans le grès rouge du Brêsil. Annales des Mines, 4me série, II, 411. Paris, 1842.

CraUssen, P.: Notes géologiques sur la province de Minas Geraes au Brésil. Bulletin de l'Academie Royale de Bruxelles, VIII, No. 5, 322-344, 1841, four plates, one geol. map. Bruxelles, 1841. Separate, 1-22, with four plates. Abstract: Nenes Jahrb. für Mineral, 1844, 234-235.

CLEMANÇON, TOUSSAINT: See Elemenøon.

CLERE, MAURICE: The gold fields of Calcoene, Brazil. Engineering and Mining Journal, LXXV, 328-329. New York, Feb. 28, 1903.

CLOUD, JOSEPH: An account of experiments made on palladium found in combination with pure gold. Transactions American Philosophical Society, VI, 407-411. Philadelphia, 1809.

COHEN, E.: Meteoreisen-Studien, XI. Annalen 7 . $k$. Naturhistorischen Hofmuseums. Redigirt von Dr. F. Steindachner, XV, Heft 3-4. Wien, 1900. (Separat-abruck aus, XV, Heft 3-4. Wien, 1900.) Meteorite from Minas Geraes, 387-388.

COHEN, E.: Meteoritenkunde. $4^{\circ}$. Stuttgart, Heft I, 1894; Heft II, 1903. (References to the Bendego and Angra dos Reis meteorites. See register, Heft I, 332 et seq.; Heft II, 292 et seq.)

COINTE, P. I.E: Le bas Amazone. Annales de Géographie, No. 61, 12e année, 54-66. Paris, Jan., 1903. (Region from Alemquer 150 miles west; geology, 59.)

COINTE, PAUI IE: Notice sur la earte du cours de l'Amazone et de la Guyane Brésilienne depuis l'océan jusqua'a Manáos. Annales de Géographie no. 86, XVI An., 159-174. Paris, 15 Mar., 1907.

COLATINo, Marques DE souZA: v. SOUZA.

COMSTOCK, T. B.: Translation of an abridged report by Professor Chas. F. Hartt upon the work of the Commissão Geologica do Brazil. American Journal of Science, 3d series, XI, 466-473. New Haven, 1876. See Hartt, Relatorio preliminar dos trabalbos da Commissão Geologica na Provincia de Pernambuco.

COMSTOCK, THEO. B.: Recent discoveries of the Brazilian Geological Commission. Amer. Jour. Sci., 3d series, XII (CXII), 464-466. New Haven, 1876. 
CONDAMINE, M. DE IA: A succinct abridgment of a voyage made within the inland parts of South America, etc. $8^{\circ}$. London, 1747. (Green stones, 70-71; pendulum observations at Pará, 90-91; pororóca, 96-99. There are several editions of this work.)

CONDAMINE, M. DE IA: Journal du voyage fait par ordre du roi a l'equateur, servant d'introduction historique à la mesure des trois premiers degrês du méridien. $4^{\circ}$. Paris, 1751. (Pierres d'Amazones, 194; pororóca, 201.)

CONRAD, T. A.: Descriptions of new fossil shells of the upper Amazon. American Journal of Conchology. Published in advance, Oct., 1870, 1-7, and plate 10. (Philadelphia, 1870), VI, 192-198. Philadelphia, 1871.

CONRAD, T. A.: Remarks on the Tertiary clay of the upper Amazon, with descriptions of new shells. Proc. Philadelphia Academy Sci., XXVI, 25-32. Philadelphia, 1874 .

COPE, E. D.: Note on the geology of Brazil. Science, I, 367-368. May 4, 1883.

COPE, E. D.: Remarks on vertebrate fossils from Brazil. American Naturalist, XVII, 1000-1001, Sept., 1883.

COPE, E. D.: A contribution to the vertebrate paleontology of Brazil. Proceedings of the American Philosophical Society, XXIII, No. 121, 1-21, with one plate. Philadelphia, Jan., 1886. Abstract: Neues Jahrbuch für Mineralogie, 1889, II, 484. Referate.

COPE, E. D.: The Carboniferous genus Stereosternum. Amer. Naturalist, XXI, 1109. Philadelphia, Dec., 1887.

COPE, E. D.: Preliminary report on the vertebrate paleontology of the Llano Estacado. 4th annual report of the Geological Survey of Texas, 1892, 60-62. Austin, Texas, 1902. (Description and figures of Dibelodon (Mastodon) humboldtii, Cuvier, a specimen of which he reports from near Pernambuco, Brazil.)

COPE, E. D.: On two extinct forms of Physostomi of the Neotropical region. Proc. Am. Phil. Soc., XII, pp. 53-55. Philadelphia, 1871. (Ancedopogon tenuidens, a fossil fish from Para?)

CORDIER: Rapport sur les resultats scientifiques du voyage de M. Alcide d'Orbigny dans l'Amérique du Sud pendant les années 1826-1833: Rapport sur la partie Géologique du voyage de M. d'Orbigny dans l'Amérique méridionale. Nouvelles Annales du Muséum d'Histoire Naturelle, III, 107-115. Paris, 1834.

CORDIER: Institut de France. Academie Royale des Sciences. Extrait des Rapports sur les résultats scientifiques du voyage de $M$. Alcide d’Orbigny dans l'Amérique du Sud (etc.). Partie geologique, pp. 4-10 of an appendix to d'Orbigny's Voyage dans l'Amérique Méridionale. $4^{\circ}$. Paris, 1842.

cossA, ALFoNso: Rutil in Gastaldit-Eklogit von Val Tournanche. Neues Jahrbuch für Mineralogie, 1880, I, 162-164, Briefliche Mittheilungen.

COSTA, ALVES: See Alves.

COSTA, FRANCISco AUGUSTO PEREIRA DA: A Iha de Fernando de Noronha. Noticia historica, geographica e economica. Mandada publicar pelo Exm. Sr. Presidente da Província Dr. Pedro Vicente de Azevedo. 117 pp. Pernambuco, 1887. Geology, 7-8; 10-12; 54-62.

costA, F. A. PEREIRA DA: Mineralogia (de Pernambuco) Jornal do Oommercio, Rio de Janeiro, 5, 8 e 19 de Julho de 1897. (Faz parte do Diccionario historico e geographico Pernambucano do mesmo autor em preparação.)

COSTA, HORORIO HERMETO CORREA DA: Artigos publicados nos annexos do Relatorio pelo Secretario de Estado dos Negocio das Finanças (do Estado de Minas Geraes) Bello Horizonte, 1905, $8^{\circ}$. 1. Generalidades sobre as minas de ouro e manganez. 21 pp. 2. Apntamentos sobre a mina de ouro da Passagem. $22-45$ pp. 3. Excursão ${ }^{*} *{ }^{*}$ as minas de $\mathbf{S}$. Bento e Sta. Quiteria. 46-76 pp. 4. Excursão ao norte (de Minas). pp. 77-94. 
COSTA, J. B. REGUEIRA: v. HARTT, C. F., v. BRANNER, J. C.

COSTA, JOSE DE REZENDE: See Rezende.

COSTA, I. A. CORREA DA: O carvão de pedra da Ilha Itaparica. Dated Rio, $1^{\circ}$ de Nov. de 1878 . Revista Industrial, Março de 1879, IV, 75 . New York, 1879. Analysis of coal copied from the Jornal do Commercio do Rio de Janeiro. This analysis is said to be published also in the Auxiliador da Industria Nacional de Julno de 1879.

COSTA, LUIZ ADOLPHo CORRE DA: Estudo geologico da região de $\mathbf{S}$. Bartholomeu e da mina de ouro da Tapera, porto de Ouro Preto. Archivos do Museu Nacional do Rio de Janeiro, III, 17-31. Rio de Janeiro, 1878.

COSTA, MANOEL TIMOTHEO DA: Resumo dos estudos preliminares da exploração das Minas de Ouro do Assurua, Comarca de Chique-Chique, Prov. da Bahia. Rio de Janeiro, 1886.

COSTA PINTO: . SIIVA, A. DA COSTA PINTO. COSTA, J. DE REZENDE: v. REZENDE COSTA.

COSTA SENA: $\nabla$. SENA, J. C. DA COSTA.

COSTARD, JOAO CAMILLO ALFONSO: Relatorio sobre uma via ferrea ao longo do Rio Jequitinhonha. Revista do Instituto Polytechnico Brazileiro, $X, 1-27,3 d$ paper. Rio de Janeiro, 1878. (Mineralogia, 15-18.)

COUDREAU, HENRI: Dix ans de Guyane. Bulletin de la Société Géographique 7me sér. XII, 447-480. Paris, 1891.

COUDREAU, H: Voyage au Xinga, 30 mai, 1896-26 octobre, 1896. $4^{\circ}, 232$ pp. Paris, 1897.

COUDREAU, H.: Voyage au Tapajos, 28 juillet, 1895-7 janvier, 1896. $4^{\circ}, 216$ pp. Paris, 1897.

COUDREAU, H.: Voyage au Tocantins Araguaya, 31 décembre--23 mai, 1897. $4^{\circ}, 300$ pp. Paris, 1897.

COURCY, Le Vicomte ERNEST DE: Six semaines aux mines d'or du Brésil, Rio de Janeiro, Ouro Preto, Saint Jean del Ré, Petropolis. Avec dessins de l'auteur. $12^{\circ}, 266$ pp. Paris, 1888.

COUTINHO, JOSE JOAQUIM DA CUNHA DE AZEREDO: Discurso sobre o estado actual das minas do Brazil. (67 pp.) Lisbôa, 1804.

CoUTINHo, J. M. DA SILVA: Relatorio apresentado ao Illmo. e Eximo. Si: Dr. Manuel Clementino Carneiro da Cunha, Presidente da Provincia do Amazonas, por J. M. da Silva Coutinho, encarregado de examinar alguns lugares da Provincia, especialmente o Rio Madeira debaixo do ponto de vista da colonisação e nevegação. Annexo ( sob letra $G$ ) ao relatorio do Ministro da Agricultura, etc., pp. 21. Rio de Janeiro, 1862.

COUTINHo, J. M. DA SIIVA: Relatorio da Exploração do Rio Purus. Annexo ao relatorio do Ministro de Agricultura, etc., pp. 96. Rio de Janeiro, 1862.

COUTINHo, J. M. DA SILVA: Exploração do Rio Madeira. Annexo (letra O) ao relatorio do Ministro de Agricultura, etc., pp. 55-63. Rio de Janeiro, 1866.

COUTINHo, J. M. DA SILVA: Exploração do Rio Hyapurá. Annexo (letra P) ao relatorio do Ministro de Agricultura, etc., 1-13. Río de Janeiro, 1866.

COUTINHO, JOĀO MARTINS DA SILVA: L'embouchure de L'Amazone. Bull. Soc. de Géogr., 321-334. Paris, Octobre, 1867.

COUTINHO, JOÃO MARTINS DA SILVA: Relatorio da commissão encarregada do reconhecimento da região do oeste da provincia de São Paulo, ete. Annexo P. do relatorio da Repartição dos Negocios da Agricultura. $4^{\circ}$. $58 \mathrm{pp}$. Rio de Janeiro, 1872. (Notes on the geology of western \$ão Paulo.)

COUTINHO, J. M. DA SILVA: Relatorio sobre o prolongamento da Estrada de Ferro Recife ao São Francisco, feito ao Governo em 1874. Notes on the geology of Pernambuco. 
COUTINHo, J. M. DA SILVA: Estrado de Ferro do Recife ao S. Francisco. Estudos definitivos de Una á Boa Vista, Rio de Janeiro, 1874. Notas sobre a geologia, pp. T-8; II, 14-18; 23-24.

COUTINHO, JOÃO MARTINS DA SILVA: v. AGASSIZ, IOUIS.

COUTO DE MAGALHĀES: V. MAGALHĀES, COUTO DE.

COUTO, JOSE VIEIRA: Memoria sobre a Capitania de Minas Geraes, seu territorio, clima e produccões metalicas; sobre a necessidade de se restabelecer e animar a mineração decadente do Brazil ; sobre o comercio e exportaç̃o de metnes $\mathrm{e}$ interesses regios. Com bum appendice sobre os diamantes e nitro natural. Tudo por ordem de Sua Majestade. Anno de 1799. Manuscript folio, $194 \mathrm{pp.} \mathrm{Dated} \mathrm{Tejuco,} 3$ de Jan. de 1799 . (In the science library of the Victoria and Albert Museum, London, Sept. 29, 1904. It is recorded as having been "copied from the originals by an English Mining Engineer . . . clearly written from Southey's collection," about 1800. It is probably the same as the third title following.)

COUTO, JOSE VIEIRA: Memorias sobre as salitreiras naturaes de Monte Rorigo; maneira de as auxiliar por meios artificias, etc., escripta no anno de $1803.4^{\circ}, 61 \mathrm{pp}$. Rio de Janeiro, 1809.

COUTO, JOSE VIEIRA: Memoria sobre as minas da Capitania de Minas Geraes, suas descripções, ensaios, e domicilio proprio, etc. Escripta em 1801. $8^{\circ}, 159+4$. Rio de Janeiro, 1842.

COUTO, JOSE VIEIRA: Memoria sobre a Capitania de Minas Geraes, seu territorio, clima, e producções metallicas: sobre a necessidade de se restabelecer e animar a mineração decadento do Brazil, etc. Escripta em 1799 pelo Dr. José Vieira Couto. Revista do Instituto Historico, XI, 289335. 2d edition (Rio de Janeiro), 1871 (for 1847).

CREVAUX, JUIJE: Faux blocs erratiques de la Plata; pretendue periode glaciare d'Agassiz dans l'Amérique du Sud. Bull. Soc. Géol. de la France, 3d série, IV, 304-8. Paris, 1876.

CREVEAUX, JULES: Voyage en Guyane. Bull. Soc. de Geographie. Nov., 1878: montagnes, 410-414; notes sur la géologie; 414-417. Paris, 1878.

CROSBY, w. $0 .:$ On the age and succession of the crystalline formations of Guiana and Brazil. Proc. Boston Soc. Natural Hist., XX, 480-497. Boston, 1880 .

CRULs: Tremblement de terre au Brésil. Comptes Rendus de l'Acad. des Sciences, CII, 1383-1384. Paris, 1886. Abstract: Neues Jahrbuch fïr Mineralogie, 1888, II, 405. Referate.

CRULS: Note sur les positions de quelques points de la côte du Brésil. (Extrait d'un Mémoire de la "Commissão de Longitudes"). Comptes Rendus de l'Acad. Sci., II (CVII), 472-473. Paris, 1888.

CRULS, L.: La futur capitale du Brésil. A Travers le Monde, nouvelle série, 2e année, 129-132. Ill. Paris, 1896.

CRUIS, I., et ANTONIO PIMENTAL: Conmission d'exploration du plateau central du Brésil. Rapport presenté à son Exc. le Mínistre de l'Industrie de la Voirie et des Travaux Publics. (Cruls chef de la Com.) Annexe 4. Rapport du Dr. Antonio Pimental. - Géologie du plateau central du Brésil, etc., in fol. VII, 2 fascieules, 365 pages, 1 fascic., 27 héliogravures. Abstract of geology and geography under titles: "Explorations in Central Brazil." The Geographical Journal. Jan., 1897, IX, 64-67. London, 1897.

CUGNIN, I.: Gites diamantifères du Brésil. Bulletin de la société de l'Industrie Minérale, III, 4me sér. 1er livraison, 247-264. $8^{\circ}$. Saint-tetienne, 1904. (With 10 half-tone plates.) Abstract: Engineering and Mining Journal, LXXVII, 893. New York, June 2, 1904.

CUMENGE, E., et F. ROBELLAZ: L'or dans la nature: minéralogie, geologie, étude des principaux gites auriferes statistique: Brésil, 1er fasciculę, p. 95. Paris, 1898. 
CTNHA, EUCLYDES DA: Os sertões (Campanha de Canudos). $8^{\circ}$. VII + 6:37 pp. Laemmert \& Co., editores. Rio de Janeiro, 1902. Geologia, feições physicas do interior da Bahia e do-Sergipe, eslıoço geologico, 1; 3-21.

CUNHA MATTOS: See Mattos.

CURLE, J. H.: Gold mining in South America. Engineering and Mining Journal; LXXX, 577. New York, Sept. 30, 1905. Quoted from the Econonist of Sept. 9, 1905.

DAFERT, F. W.. See Derby, $0 . A$.

D'ARChIAC, A.: Histoire des progrès de la géologie de 1834 à 1845 . Publiée par la Sociêté Géologique de France, II, Brésil, 379-386. $8^{\circ}$. Paris, 1848.

D'ARCHIAC, A.: Histoire des progrés de la géologie de 1834 a 1852, V, Brésil, 549-552. $8^{\circ}$. Paris, 1853.

D'ARChIAC, A.: Histoire des progrés de la géologie de 1834 à 1859, VIII, Brèsil, 549-552. Paris, 1860 .

D'ARCUNAA: See Acuña.

DAFNE, EUGENIO: (A bacia carbonifera do Arroio dos Ratos.) Revista de Engenharia, No. 219, XI, 234. Rio de Janeiro, 14 de Out., 1889.

DAHNE, E. S. EUGENIO: A mineraç̃̃o do carvão e as concessões da conpanhia no Estado do Rio Grande do Sul, Brazil, $4^{\circ}$. 111 pages, map, and sections. Porto Alegre, 1893.

DAFNE, EUGEMIO: A formação carbonifera em Tubarão, Santa Catharina. Estudo geologico feito pelo engenheiro de minas Eugenio Dahne em 1901. Publicado no jornal "A Federacão" Porto Alegre, Estado do Rio Grande do Sul, anno XXI, No. 39 . 16 de Fer. de 1904.

DAHNE, FUGENIO: Descriptive memorial of the state of Rio Grande do Sul, Brazil. Organized by order of the President, Dr. Antonio Augusto Borges de Medeiros for the International Exhibition at $\mathbf{S}$. Luiz, 1904. Porto Alegre, 1904. Geology and minerals, 6-17.

DAIL, WILIIAM HEALEY: Mollusks from the vicinity of Pernambuco. Results of the Branner-Agassiz expedition to Brazil. Proc. Wash. Acad. Sci., III, 139-147. Washington, 1901.

DALL, W. H.: A new proserpinoid land shell from Brazil. Proc. Biol. Soc. Wash., XVIII, 201-202. Washington, Sept. 2, 1905.

DALTON, HENRY G.: The history of British Guiana. (. . .) together with an account of its climate, geology, staple products and natural history. In 2 vols. $\left(8^{\circ}\right.$.) London, 1855 . I. Introductory chap., pp. 1-58, on physical features and geology.

DAMAzIo, LEONIDAS: Analyses feitas no laboratorio de docimasia da Eiscola de Minas de Ouro Preto.

I. Manganez e ferro da Provincia de Sta. Catharina....... p. 201

II. Ouro do Tapuia, Bahia......................... p. 202

Ouro de Itapicura, Bahia...................... p. 202

III. Terra rôxa de Ypanema ...................... p. 203

IV. Terra das grutas de Carandahy $\ldots \ldots \ldots \ldots \ldots \ldots \ldots \ldots \ldots$ p. 203

V. (Com H. Gorceix) Amostras de phosphatos............ pp. 203-207

VI. Ouro de Vasado............................. pp. 207-208

Annaes da Escola de Minas de Ouro Preto, No. 4, 201-208.. 1885.

DAMOUB, A.: Analyse de la bornine du Brésil (tellurure de bismuth). Comptes Rendus de l'Acad. Sci., XIX, 1020-1021. Paris, 1844.

DAMOUR, A.: Analyse d'un tellurure de bismuth du Brésil. (Josëite.) Annales de Chimie et de Physique, 3me série, XIII, 372-376. Paris, 1845. Annales des Mines, 4me série, VIII, 699-700. Paris, 1845.

DAMOUR: Catalogue des minéraux recueillis par M. de Castelnau dans les gites métalliferes du Brésil, de la Bolivie, du Chili et du Pérou, v, 430-445 of the Histoire du Voyage. Expedition de Francis de Castelnau, q. v. $8^{\circ}$, Paris, 1851. 
DAMOUR, A.: Examen minéralogique et chimique d'un sable diamantifère de la province de Bahia. Société Philomatique de Paris. Extraits des procès-verbaux des séances pendant l'année, 1853, 14-20. Paris, 1853.

DAMOUR, A.: Nouvelles recherches sur les sables diamantifères. Bull. Soc. Géol., 2me série, 1855-56, XIII, 542-554. Paris, 1856. Abstract: Neues Jahrbuch für mineralogie, 818-819, 1858.

DAMOUR, A.: Sur un fer métallique trouvé à Santa Catharina, Brésil. (With remarks by Boussingault.) Comptes Rendus de l'Acad. Sci., LXXXIV, 478-482. Paris, 1877. Abstract: Zeitschrift für Krystallographie und Mineralogie. (Groth.) I, 407.

DAMOUR: Note sur le spinelle zincifère (Gahnite) du Brésil. Bull. Soc. Mineral. de France, I, 93-94. Paris, 1878. Abstract: The Geological Record for 1878, 242. Londou, 1882. Also, Zeitschrift für Krystallographie und Mineralogie. (Groth.) III, 641. Leipzig, 1879.

DAMOUR, A.: Note sur un nonveau phosphate d'alumine et de chaux des terrains diamantifères. (Goyazite.) Bulletin de la société Minéralogique de France, VII, 204-205. Priris, 1884. Abstract: Zeitschrift für Krystallographie und irincralogie. (Groth.) XI, 688. Leipzig, 1886.

DARWIN, C.: On a remarkable bar of sandstone off Pernambuco on the coast of Brazil. The London, Edinburgh and Dublin Phil. Mag. and Journal of Sci., XIX, 257-260. London, Oct., 1841. Translation: 0 recife de gres do porto de Pernambuco. Traduzido por Alfredo de Carvalho. Revista do Instituto Archeologico e Geographico Pernambucano, No. 60, 196-200. Recife, 1904.

DARWIN, CHARLES: Geological observations on South America, being the third part of the geology of the voyage of the "Beagle," etc. $8^{\circ}$. London, 1846. (Brazil, 3 ; 140-144.)

DARWIN, CHARLES: Geological observations on the volcanic islands and parts of South America visited during the voyage of $H$. M. S. "Beagle." Maps and illustrations. London, second edition, 1876. References to Brazilian geology, 27-28; 193 foot-note; 422-428. This is the second edItion of preceding title. This work was trauslated into German and published under the title: Geologische Beobachtungen über Süd-America angestellt während der Reise des "Beagle" in den Jahren, 1832-1836. Aus dem Englischen Uebersetzt von J. Victor Carus. Mit 1 Karte, 5 Tafeln und 24 Holzschnitten. $8^{\circ}$. X +400 pp. Stuttgart, 1878. Published in French under the title: Observations gêologiques sur les iles volcaniques. Traduction A. F. Renard, de la 3 ed. 1 vol. avec 14 figures et une planche. $8^{\circ}$. 218 pp. Paris, 1902.

DARWIN, CHARLES: Journal of researches into the natural history and geology of the countries visited during the voyage of $H$. M. S. "Beagle" round the world under the command of Capt. Fitz Roy. New edition. New York, pp. $X+519$. 1878. Geological notes on Brazil. French edition: Voyage d'un naturaliste autour du monde fait a bord du navire "Beagle" de 1831 a 1836. Traduction Ed. Barbier. 1 vol. avec gravures. Paris.

DARWIN, CHARLES: The structure and distribution of coral reefs. Third edition. With an appendix by T. G. Bonney. 73, 77, 277-280. London, 1889.

DAUBER: Ueber Crocoite von Congonhas do Campo, Minas Geraes. Sitzsungsberichte $d$. kk. Alkademie d. Wissenschaft. XLII, 19. Vienna, 1860.

DAUBREE: Observations sur le fer natif de Sainte Catherine, sur la pyrrhotine et la magnétite qui lui sont associées. Comptes Rendus de l'Acad. Sci., LXXXIV, 482-485. Paris, 1877.

DAUBREE: Constitution et structure brêchiforme du fer m̧etéorique de Sainte Catherine, Brésil (etc.) Oomptes Rendus de l'Acad. Sci., LXXXV, 1255-1260. Paris, 1877. Abstract: Zeitschrift fïr Krystallographie und Mineralogie. (Groth.) II, 516-517. Leipzig, 1878. 
DAUBREF: Sur le grand nombre de joints, la plupart perpendiculaires entre eux qui divisent le fer netéorique de Sainte Catherine (Brésil). Comptes Renaus de l'Acad. Sci., LXXXVI, 1433-1434. Paris, 1878.

DAUBREF: Présente à l'Academie de la part de S. M. dom Pedro la photographie d'un fragment poli du fer météorique ou holosidère de Bendegó, Brésil. Comptes Rendus de l'Acad. Sci., II (CVII), 896-897. Paris, 1888.

DAVID, Prof.; GUTHRIE, F. B.; WOOLNOUGH, W. G.: On the occurrence of a variety of Tinguaite at Kosciusko, N. S. Wales. Journal and Proceedings of the Royal Society of New South Wales, XXXV, 347-355. Sydney, 1902. (Brazil, cited 352-353.)

DAVIES, THOMAS: The natural history of the island of Fernando de Noronha, based on the collections made by the British Museum Expedition in 1887. Extracted from the Linnean Society's Journal-Botany, vol. XXVI, 86-94. London, 1890. Geology of Fernando de Noronha.

D(AVIS), W. M.: Facetted pebbles. (Notes regarding the paper of M. A. Lisboa on this subject.) Amer. Jour. Sci., CLXXIII, 150. New Haven, Feb., 1907.

DAWSON, J. W.: Biographic notice of C. F. Hartt. Canadian Naturalist, new series, VIII, 446-447. Montreal, 1878.

DAWSON, J. W.: Note on limestone from the gneiss formation of Brazil. Amer. Jour. Sci., XIX, 326. New Haven, 1880.

DAWsow, J. W.: On Rhizocarps in the Palseozoic period. Proceedings American Association for the Advancement of Science, 32d meeting, 1883. 260 264. Salem, 1884. (Illustrated.) Canadian Record of Science, I, 19-27. Montreal, 1885. (Rhizocarps from Rios Trombetas and Curud.)

DAWsON, J. W.: Sobre os rhyzocarpos do periodo palæozoico (dos schistos do Rio Tapajos, Trombetas, e Curuá, etc.). Revista de Engenharia, VII, 1-4, ill. Rio de Janeiro, 14 de Janeiro, 1885.

DAWSON, J. W.: The geological history of plants. International scientific series, LXIII. London, 1888. (Rhizocarps from Brazil, 53-54; Devonian and Carboniferous, 147.)

DAWSON, THOMAS C.: Diamond and gold mining in Minas Geraes. (U. S.) Consular Reports, LX, May, June, July, and August, 1899, 535-553. Washington, 1899. This article was republished in German as follows: Die Mineralien-, insbesondere Diamanten-, und Gold- production in Minas Geraes, Brasilien. Berg- und Huettenmaennische Zeitung, LVIII, 505-507; 517-519. Leipzig, Oct., 1899.

DAWSON, THOMAs C.: The South American Republics. (Brazil, part I.) $8^{\circ}$. G. P. Putnam's Sons, New York and London, 1903. Gold in Brazil, 310 ; 378-380 ; 391-393; 397 ; 405, diamond mining; $392 ; 397$.

DELDEN LAËRNE, C. F. VAN: V. LAERNE.

DE L'ISLE, DE ROME: Crystallographie ou description des formes propres a tous les corps du regne mineral. 2me edition, 3 vols. $8^{\circ}$. Paris, 1783. Treats of Brazilian minerals, chatoyantes, chrystolite, rubis, diamant, emeraude, peridot, saphir, topaze, tourmaline.

DE I'ISLF, DE ROM E: Essai de Crystallographie ou description des figures géométriques, etc. $8^{\circ}$. Paris, 1772. (Brazilian minerals; diamant, 203, 387 ; rubis, 216-219; saphir, 221-222 ; topaze, 223-226; chrysolite, 231; emeraude, 239-243.)

DENIS DE HERVE, SEBASTIAN JOSEPH: Notice sur le gisement et l'exploitation au diamant dans la province de Minas-Geraes au Brésil. $B u l$ letin de l'Académie Royale des sciences et Belles-Lettres de Bruxelles, VII, 133-148, one colored geological plate, $8^{\circ}$. Bruxelles, 1840.

DENIS, M.: Gisement du diamant au Brésil. L'Institut. $8^{\circ}$ annêe. No. 342 , VIII, 241-242. $4^{\circ}$. Paris, 1840. (This is an abstract of the article by Denis in the Bulletin de l'Académie Royal des Sciences et Belles-Lettres do $B$ ruxelles cited above.) 
DENIZ, AIPHEU: As argillas do Barbalho (Bahia). Boletim da Secretaria de Agricultura, etc., do Estado da Bahia II, No. 111, 221-223. (Analyse) Bahia, 1903.

DENIZ, A. v. GONÇALVES.

DERBY, O. A.: On the Carboniferous brachiopoda of Itaitúba, Rio Tapajos, Province of Pará, Brazil. Bull. Cornell University (Science), I, No. 2, 1-63, plates I-IX. Ithaca, N. Y., 1874. Abstract: O Novo Mundo, Agosto 23, 1874, IV, 206. New York, 1874.

DERBY, O. A.: Notice of the paleozoic fossils (accompanying a memoir entitled "Exploration of Lake Titacaca," by Alexander Agassiz and S. W. Garman). Bulletin of the Museum of Comparative Zoology, III, no. 12, 279-286. Cambridge, Mass., 1875.

DERBY, O. A.: Note on the fossils from the River Pichis, Peru. The Andes and the Amazon, by James Orton, 557-558. New York, 1876. (The name of Mr. Derby is here set down as "Dewey.")

DERBY, O. A.: Contribuições para e geologia da região do Baixo Amazonas. Archivos do Muse u Nacional, II, 77-104. Rio de Janeiro, 1877. Same article in English in the Proceedings of the American Philosophical Society, XVIII, 155-178. Philadelphia, 1879. Portions are reproduced in the Diccionario geographico das Minas do Brazil por Francisco Ignacio Ferreira, 24-51. Rio de Janeiro, 1885.

DERBY, O. A.: A bacia cretacea da Bahia de Todos os Santos. Archivos do Museu Nacionál, III, 135-158. Rio de Janeiro, 1878.

DERBY, O. A.: The artificial mounds of the Island of Marajo, Brazil. American Naturatist, April, 1879, 224-229. A Portuguese translation : Os montes artificiaes da ilha de Marajo. O Novo Mundo, VIII, 90 New York, Abril, 1878.

DERBY, O. A.: Observações geologicas na estrada da ferro Sorocabana. Revista de Instituto Polytechnico de S. Pauln, 1878.

DERBY, O. A.: Geologia da região diamantifera da Provincia do Parana no Brazil. Archivos do Museu Nacional do Rio de Janeiro, III, 89-96. Río de Janeiro, 1878. Same article in English: Proc. Am. Phil. Soc., XVIII, 251-258. Philadelphia, 1879. Abstract: American Journal of Science, $3^{\circ}$ ser., VIII (CVIII), 310. New Haven, 1879. Notice: Popular science Monthly, XVI, 423-424. New York, 1880.

DERBY, O. A.: Contribuições para o estudo da geologia do Valle do Rio São Francisco. Archivos do Museu Nacional, IV, 87-119. Río de Janeiro, 1879.

DERBY, O. A.: Observações sobre algumas rochas diamantiferas de Minas Geraes. Archivos do Museu Nacional, IV, 121-132. Rio de Janeiro, 1879.

DERBY, O. A.: A contribution to the geology of the lower Amazonas. Proc. Amer. Phil. Soc., XVIII, 155-178. Philadelphia, 1880. Review: Popular Science Monthly, XVI, 421. New York, Jan., 1880.

DERBY, O. A.: Reconhecimento geologico do Valle de S. Francisco, 24 pp. $4^{\circ}$. Annexo ao relatorio de W. Milnor Roberts, Engenheiro Chefe da Commissão Hydraulica sobre o exame do Rio S. Francisco (etc.). Rio de Janeiro, 1880. Tambem na Revista de Engenharia, III, 93-94; 1̄̄5-127; $139-143 ; 172-175 ; 188-190$. Rio de Janeiro, 1881.

DERBY, O. A.: Geology of the Rio São Francisco, Brazil. American Jour. Sci., 3d series, XIX (CXIX), 236. New Haven, March, 1880.

DERBY, O. A.: On the age of the Brazilian gneiss series. Discovery of Eozoon. Amer. Jour. Science, 3d series, XIX, 324-5. New Haven, April, 1880. Idade da serie dos gneiss brazileiros. Revista de Engenharia, II, 115-116. Rio de Janeiro, 1880.

DERBY, O. A., and BARROS, LUIZ MONTEIRO DE: Jazidas de phosphato de cal existentes na Ilha Rata (sic.), do archipelago de Fernando de Noronha. Relatorio da Commissão nomeada para examinar as jazidas. 
Rio de Janeiro, 7 de Fevereiro de 1881. Relatorio do Ministro da Agricultura, 1882. Annexos. Revista de Engenharia, III, 26 et seq. Rio de Janeiro, 1881. Revista Agricola do Imperial Instituto Fluminense de Agricultura, XII, N. 2, 55-61. Rio de Janeiro, Junbo de 1881. "A ilha de Fernando de Noronha, etc.," por Francisco Augusto Pereira da Costa. Pernambuco, 1887, q. $\nabla$.

DERBY, O. A.: Geology of the diamond. Amer. Jour. Sci., 3d series, XXIII (CXXIII), 97-99. New Haven, Feb., 1882. Also in The Rio Neus, IX, 3. Rio de Janeiro, March 15, 1882.

DERBY, O. A.; On the gold-bearing rocks of the province of Minas Geraes, Brazil. Amer. Jour. Sci., 3d series, XXIII (CXXIII), 178. New Haven, March, 1882.

DERBY, O. A.: Modes of occurrence of the diamond in Brazil. Amer. Jour. Science, 3d series, XXIV (CXXIV), 34-42. New Haven, July, 1882. Abstract: Zeitschrift für Krystallographie und Mineralogie. (Groth.) VII, 427. Leipzig, 1883.

DERBY, O. A.: Relatorio apresentado ao Sr. Conselheiro Manoel Alves de Araujo Ministro de Agxicultura, Commercio e Obras Publicas, acerca dos estudos geologicos practicados nos valles do Rio das Velhas e alto $\mathbf{S}$. Francisco, 38 pp. Rio de Janeiro, 1822.

DERBY, O. A.: On Brazilian specimens of Martite. Amer. Jour. Sci., 3d series, XXIII (CXXIII), 373-374. New Haven, May, 1882. Abstract: Neues Jahrbuch für Mineralogie, I, 194. (Referate.) 1883.

DERBY, O. A.: Plantas fosseis (no Brazil). Revista de Engenharia, V, 348. Rio de Janeiro, 28 de Dezembro de 1883. Extrahido de Jornal do Commercio do Rio de Janeiro.

DERBY, O. A.: Terrenos carboniferos das provincias de S. Paulo e Parana. Revista de Engenharia, V, 228-229. 28 de Agosto de 1883. Extrahido do Jornal do Commercio do Rio de Janeiro, 1883. Also in the Auxiliador da Industria Nacional, n. 11, 258-260. Rio de Janeiro, Novembro, 1883.

DERBY; O. A.: 'The human remains of the bone-carerns of Brazil. Science, I, 541. 1883.

DERBY, O. A.: O Brazil geographico e historico; A terra e o Homem, por J. E. Wappaeus. A geographia physica do Brazil refundida. Edição condensada. - Cap. IV, aspecto physico, montanhas e chapadões, 36-43. Cap. V. Estructura geologica e mineraes, 44-59. Cap. VI, Caracteristica geral das vertentes e das bacias fluviaes, 60-70. Rio de Janeiro, 1884. Chap. V is also reprinted as an appendix to "Resumo de geologia," por A. de Lapparent. Traduzido da 3a edição pelo Dr. B. F. Ramiz Galvão. pp. 333-343.

DERBY, O. A.: Fosseis de S. Paulo. Revista de Engenharia, VI, 233-234. Rio, 1884. (From the Jornal do Commercio.) Rio de Janeiro, 28 de Out., 1.884.

DERBY, O. A.: Physical geography and geology of Brazil. The Rio News, Dec. 5th, p. 3; 15th, p. 3 ; and 24 th, pp. 3-4. Rio de Janeiro, 1884 . Separates of the Rio News articles were published at Rio de Janeiro in 1884 , with two lithographs, 13 pp. $8^{\circ}$. In Portugnese in Wappaeus, q. v. In German, translated from the Portuguese edition, with notes by Dr. E. A. Goeldi, and published under the title: Physikalische Geographie und Geologie Brasíliens, in Mittheilungen der Geographischen Gesellschaft ( $\mathrm{fur}$ Thüringen) $\approx u$ Jena, V, 1-20. Abstract: Neues Jahrbuch für Mineralogie, II, 57-59. (Referate.) 1886.

DERBY, ORVIIIE A.: Note on the decay of rocks in Brazil. Amer. Jour. Sci., Feb., 1884, 3d series, XXVII, 138-9 (CXXVII). In Portuguese: Nota sobre a decomposição das rochas no Brazil. Revista de Engenharia, VI, 64. Rio de Janeiro, 28 de Março, 1884.

DERBY, O, A.: Geologia do diamante. As rochas auriferas de Minas Geraes. Sobre amostras brazileiras de Martito. Auxiliador aa Industria Nacional, n. 5, 101-103. Rio de Janeiro, Maio, 1884. 
DERBY, 0. A.: Observações sobre os calcareos do Rio de Janeiro, Minas, e S. Paulo. Revista de Engenharia, VI, 26-28. Rio de Janeiro, 14 de Fev., 1884. Auxiliador da Industria Nacional, n. 4, 83-87. Rio de Janeiro, Abril, 1884. A part of the same article under the title "Limestone formations" in The Rio News, p. 3. Rio, March 5, 1884.

DERBY, O. A.: Calcareos hydraulicos de S. Paulo. Revista de Engenharia, VI, 116-117. Rio de Janeiro, 28 de Maio, 1884.

DERBY, O. A.: On the flexibility of itacolumite. Amer. Jour. Sci., 3d series, XXVIII (CXXVIII), 203-205. New Haven, 1884.

DERBY, O. A.: Peculiar modes of occurrence of gold in Brazil. Amer. Jour. Sci., XXVIII (CXXVIII), 440-447. New Haven, 1884. Abstract: Zeitschrift für Krystallographie und Mineralogie. (Groth.) XI, $295 . \quad$ Leipzig, 1886.

DERBY, O. A.: Analyses of Brazilian minerals. Amer. Jour. Sci., XXVII (CXXVII), 73-74. New Haven, Jan., 1884. Abstract: Neues Jahrbuch für Mineralogie, 1885, II, 257. (Referate.)

DERBY, O. A.: The Santa Catharina meteorite. Amer, Jour. Sci., XXIX (CXXIX), 33-35; 496. New Haven, Jan., 1885.

DERBY, O. A.: Is Brazil a fertile country? The Rio News, March 5, 1885. XII, 3. Rio de Janeiro, 1885.

DERBY, O. A.: The physical features of Brazil. Science, V, 273-275. One map. New York, April 3, 1885 . Taken from The Rio News, XI, 3-4. Rio de Janeiro, Dec. 15, 1884.

DERBY, O. A.: The drainage system of Brazil. Science, $\mathrm{V}, 296-299$. New York, April 1C, 1885. From The Rio News, XI, 3-4. Rio de Janeiro, Dec. 24,1884 .

DERBY, O. A.: Note on Brazilian minerals. Amer. Jour. Sci., CXXIX, 70-71. New Haven, 1885.

DERBY, O. A.: (O Carbonifero do Amazonas.) Revista de Engenharia, 14 de Jan. de 1885, VII, 10-12. From the Jornal do Commercio, Rio de Janeiro, 1885 .

DERBY, O. A.: Contribuição para o estudo da geographia physica do Valle do Rio Grande. Revist. Soc. de Geogr. do Rio de Janeiro, I, 291-318. Rio de Janeiro, 1885.

DERBY, O. A.: Esquisse géologique (du) Brésil. Annuaire géologique universel et guide du géoloque, etc. II, 2e partie, 29-35. Paris, 1886.

DERBY, O. A.: (?) under signature "Y. A." Letter referring to eruptive rocks in the Province of Rio de Janeiro. Science, VIII, 477-478. New York, 1886.

DERBY, O. A.: Carta sobre a geologia da região, dirigida ao Dr. P. de Mello Brandão. As aguas mineraes de Araxa, 9-15. Rio de Janeiro, 1886.

DERBY, O. A.: Mineral novo do Brazil (Laavenite). Revista de Engenharia, No. 168, IX, 189. Rio de Janeiro, 28 de Agosto, 1887. From Graeff in Neues Jahrbuch fïr Mineralogie, G. \#. Pal., 1887, I, 201-208.

DERBY, O. A.: Observações sobre a taboa [dos fosseis cretaceos do Brazil descriptos por C. A. White]. Archivos do Museu Nacional do Rio de Janeiro, VII, 269-273, $4^{\circ}$. Janeiro, 1887.

DERBY, O. A.: The genesis of the diamond. Science, IX, 57-58. 1887.

DERBY, O. A.: On Nepheline rocks in Brazil : Part I, with special reference to the association of Phonolite and Foyaite. Quart. Jour. Geol. Soc., XLIII, 457-473, sketch map and figures. London, 1887. Abstract of Part I in Neues Jahrbuch für Mineralogie, I, 119, 1889. (Referate.) Part II, The Tingua mass. Quart. Jour. Geol. Soc., XIJII, 251-265. London, 1891. Abstract of Part II in Neues Jahrbuch für Mineralogie, I, 522. (Referate.) 1892. Abstract: The Year-Book of Science for 1891, 267. Iondon, 1892. The same in Portuguese: Sobre as rochas nephelinas do Brazil, com especial referencia a associação do phonolyto e foyaito. $R e$ - 
vista de Engenharia, No. 186, 28 de Maio de 1888; X, 111-114; No. 187, 14 de Junho de $1888 ; \mathrm{X}, 121-123 ;$ No. $188, \mathrm{X}, 133-136$. Rio de Janeiro, 1888.

DERBY, O. A.: Relatorio apresentado ao Visconde do Parahyba pela Commissão geographica e geologica da Provincia de São Paulo. 11-28. São Paulo, 1888.

DERBY, O. A.: Ueber Spuren einer carbonen Eiszeit in Südamerika. Neues Jahrbuch für Mineralogie, II, 172-176. Stuttgart, 1888.

DERBY, O. A.: Notas sobre os meteoritos Brazileiros. Revista do Observatorio do Rio de Janeiro, 1888, III, No. I, 3-6; No. II, 17-20; No. III, 33-77. Abstract: Amer. Jour. Sci., 3d series, XXXVI (CXXXVI), 157. New Haven, 1888. Abstract of abstract in Amer. Jour. Sci., Neues Jahrbuch für Mineralogie, II, 281, $1889 . \quad$ (Referate.)

DERBY, 0. A.: On the occurrence of Monazite as an accessory element in rocks. Amer. Jour. Sci., CXXXVII, 109-113. New Haven, 1889. Abstract: Bull. Soc. Frangaise de Minéralogie, XII, 508. Paris, 1889. Abstract: Zeitschrift für Krystallographie und Mineralogie (Groth), XIX, 78. Leipzig, 1891.

DERBY, O. A.: Retrospecto historico dos traballos geographicos e geologicos effectuados na Provincia de S. Paulo. Boletim. No. 1 da Commissão Geographica e Geologica da Provincia de S. Paulo. 26 pp. $8^{\circ}$. São Paulo, 1889.

DERBY, O. A.: Relatorio da Commissão Geographica e Geologica da Provincia de São Paulo, 5-42. São Paulo, 1889.

DERBY, O. A.: Os picos altos do Brazil. Revist. Soc. de Geogr. do Rio de Janeiro, 1889, V, 129-149; 1890, V, 69-70. Abstract: Neues Jahrbuch für Mineralogie, 1891, II, 304-305 (Referate.) Extracts: L'Etoile $d u$ Sud, Rio de Janeiro, 19 Janvier, 1892; Bulletin de Géographie Commercial de Bordeaux, 2me série XV, 156-157. Bordeaux, 1892.

DERBY, O. A.: (Holosidero do Bendigô.) Revista de Engenharia, No. 244, XII, 261. Rio de Janeiro, 28 de Outubro, 1890.

DERBY, O. A.: The Bendego (Brazil) meteorite. Abstract: Proc. Amer. Assoc. Adv. Sci., 1890, XXXIX, 262. Salem, 1891.

DERBY, O. A.: Observations on the genesis of certain magnetites. Abstract: Proc. Amer. Assoc. Adv. Sci., 1890, XXXIX, 263. Salem, 1891.

DERBY, O. A.: Nephelene-bearing rocks in Brazil. Abstract: Proc. Amer. Assoc. Adv. Sci., 1890, XXXIX, 263. Salem, 1891.

DERBY, O. A.: On the separation and study of the heavy accessories of rocks. Proceedings of the Rochester Academy of Science, I, 198-206. Rochester, N. Y., 1891. Abstract: The Year-Book of Science for 1892, 267-268. London, 1892.

DERBY, O. A.: (Apatite in the iron ore of Ipanema.) Revista de Engenharia, No. 271, XIII, 634. Rio de Janeiro, 14 de Dezembro, 1891 . From the Diario Official de S. Paulo, de 1891.

DERBY, O. A.: On the occurrence of xenotime as an accessory element in rocks. American Journal of Science, XLI, 308-311. New Haven, April, 1891. Abstract: The Year-Book of Science for 1891, 262. London, 1892.

DERBY, O. A.: On the magnetite ore districts of Jacupiranga and Ipanema, São Paulo, Brazil. Am. Jour. Sci., XLI, 311-321. For erratum v. p. 522. New Haven, April, 1891. Also separate. Abstract: Neues Jahrbuch fï. Mineralogie, 1894, I. 90. Abstract: Journal of the Iron and Steel Institutc, 1891, II, 148. London, 1891.

DERBY, O. A.: Is the São Francisco do Sul (Santa Catherina) iron a meteorite? Science, XX, 254-255. New York, Nov. 4, 1892.

DFRBY, ORVILIE A.: A study in consanguinity of eruptive rocks. Journal of Geology, I, No. 6, 597-605. Chicago, 1898.

DERBY, O. A.: Humboldt and Brazil. Science, XXII, 91, 1893. 
DERBY, O. A.: Origem sedimentaria dos minerios de ferro. Revista Industrial de Minas Geraes. Anno I, n. 7, 155-159. Ouro Preto, 15 de Abril, 1894.

DERBY, O. A., and F. W. DAFERT: On the separation of minerals of high specific gravity. Proceedings of the Rochester Academy of Science, vol. 2, 122-123. Rochester, N. Y., 1893.

DERBY, O. A.: The Amazonian Upper Carboniferous fauna. Journal of Geology, II, No. 5, 480-501. Chicago, 1894 .

DERBY, O. A.: Investigações geologicas do Brazil. Revista Brazileira, II, 140-157. Rio de Janeiro, Maio, 1895. Also as appendix to "Resumo de Geologia," por A. de Lapparent. Traduzido da 3a edição pelo Dr. B. F. Ramiz Galvão, 312-333. Rio de Janeiro.

DERBY, ORVILLE A.: Nota sobre a geologia e paleontologia de Matto Grosso. Archivos do Museu Nacional do Rio de Janeiro, IX, 59-88. Rio de Janeiro, 1896. (Portuguese and English.)

DERBY, O. A.: Estudo sobre o meteorito de Bendegó. (Portuguese and English.) Revista do Museu Nacional do Rio de Janeiro, I, 89-184. Rlo de Janeiro, 1896. Abstract: Am. Jour. Sci., 4th series, IV (CLIV), 159160. Abstract: Neues Jahrbuch für Mineralogie, 1898, II, 27-28. (Referate.) Abstract: Zeitschrift für Krystallographie und Mineralogie (Groth), XXX, 397-398. Leipzig, 1899.

DERBY, ORVILLE A.: Decomposition of rocks in Brazil. Journal of Geology, IV, 529-540. Chicago, 1896.

DERBY, O. A.: Letter regarding the Cretaceous and Tertiary of Brazil, addressed to G. D. Harris (1896). See HarRIs, G. D.

DERBY, O. A.: Review of Branner's "Decomposition of rocks in Brazil." Revista Brazileira, VII, 132-140. Rio de Janeiro, 1896.

DERBY, O. A.: Monazite and xenotime in European rocks. Mineral Mag. and Journal Mineralogical Soc., XI, 304-310. London, Dec., 1897.

DERBY, O. A.: Trabalhos restantes ineditos da Commissão Geologica do Brazil, 1875-1878. Boletim do Museu Paraense, II, no. 2. Pară, 1897-8. Abstract: Petermann's Mittheilungen, Lit., 208, 1898. I, A tha de Maraj6, II, No. 2, 163-173 ; IV, Reconhecimento do Rio Mãecurú, II, No. 2, 192-204; VI, A Serra de Maxirá, II, No. 3, 340-343; VII, A Serra de Tajuri, II, No. $3,344-351 ; X$, O Rio Trombetas, No. 3, 366-382.

DERBY, O. A.: Bendig6, the great Brazilian meteorite. Extracts from articles by Mr. Derby published in The Brazilian Bulletin. Organ of Mackenzie College, São Paulo, Brazil, I, No. I, 30-32. June, 1898.

DERBY, O. A.: On the accessory elements of Itacolumite and the secondary enlargement of tourmaline. Amer. Jour. Sci., 4th series, V (CIJV), 18i192. New Haven, 1898. Abstract: Zeitschrift für Krystallographie und Mineralogie (Groth), XXXII, 591. Leipzig, 1900.

DERBY, O. A.: Brazilian evidence on the genesis of the diamond. Journal of Geology, VI, 121-146. Chicago, 1898. Abstract: Brazilian Bulletin, I, No. 2, 65-67. Sept., 1898. One half tone of diamond washing. Notice: Zeitsch. für Praktische Geologie, 213-217. Juin, 1899. Abstract: Zeitschrift für Krystallographie und Mineralogie (Groth), XXXII, 603. Leipzig, 1900.

DERBY, O. A.: On the association of argillaceous rocks with quartz veins in the region of Diamantina, Brazil. American Jour. Sci., 4th series, VII (CLVII), 343-356. New Haven, 1899. Abstract: Neues Jahrb. für Mineral., I, 412-413, 1901. Abstract: Zeitschrift für Krystallographie und Mineralogie (Groth), XXXIV, 101. Leipzig, 1901.

DERBY, o. A.: (Manganese in Brazil.) Twentieth annual report of the $\mathrm{U}$. $\mathrm{s}$. Geol. Survey, part VI, 140-142. Washington, 1899.

DERBY, O. A.: Notes on monazite. Amer. Jour. Sci., X, 217-221. New Haven, 1900. Abstract: Zeitschrift für Krystallographie und Mineralogie (Groth), XXXVI, 69. Leipzig, 1902. 
DERBY, O. A.: Notes on certain schists of the gold and diamond regions of eastern Minas Geraes, Brazil. Amer. Jour. Sci., X, 207-216. New Haven, 1900.

DERBY, O. A.: (On the manganese ores of Brazil), pp. 32-37 of the separate of the article by $H$. K. Scott on the same subject. London, 1900. See ScOTT, H. K.

DERBY, O. A.: The supposed Tertiary sea of southern Brazil. Science, XIII, 348-9. New York, March 1, 1901.

DERBY, O. A.: On the manganese ore deposits of the Queluz (Lafayette) District, Minas Geraes, Brazil. Amer. Jour. Sci., XII, 18-32. New Haven, July, 1901.

DERBY, O. A.: On the mode of occurrence of Topaz near Ouro Preto, Brazil. Amer. Jour. Sci., 4th ser., XI, 25-34. New Haven, Jan., 1901. Abstract: Review American Chemical Research, VII, 73. Abstract: Zeitschrift für Krystallographie und Mineralogie (Groth), XXXVII, 71. Leipzig, 1902.

DERBY, O. A.: Os primeiros descobrimentos de ouro em Minas Geraes. Revista do Instituto Historico e Geographico de São Paulo, V, 240-278. S. Paulo, 1901. Also in Estado de São Paulo, Sept. 24, 25; Nov. 9, 10, 26, 1900.

DERBY, O. A.: Os primeiros descobrimentos de ouro nos districtos de Sabará e Caethé. Revista do Instituto Historico e Geographico de São Paulo, V, 279-295. S. Paulo, 1901.

DERBY, O. A.: Notes on Brazilian gold ores. Trans. Amer. Inst. Min. Engineers, May, 1902, XXXIII, 282-288. Separate (6 pp.). New York, 1902. Republished in Engineering and Mining Journal, LXXIV, 142-143, Aug. 2, 1902. Zeitschrift für Praktische Geologie, XI, 111-113, 1903. Abstract: Neues Jahrbuch für Mineralogie, 411, 1904.

DERBY, O. A.: On the occurrence of monazite in iron ore and in graphite. Amer. Jour. Science, CLXIII, 211-212. March, 1902.

DERBY, O. A.: v. HARTT, OF. F.

DERBY, O. A.: As madeiras petrificadas do Estado de São Paulo. Almanach Melillo para 1904, 150-151. São Paulo, 1903.

DERBY, O. A.: Review of Branner's "Stone reefs of Brazil." science, XXI, 738-740, May 12, 1905. Also in Jornal do Commercio, Rio de Janeiro, April 15, 1905, and Diario de Pernambuco, 3 de Maio, 1905.

DERBY, O. A.: As lavras diamantinas da Bahia. Un relatorio apresentado ao Secretario de Agricultura do Estado da Bahia, 23 de Maio de 1905. Diario de Bahia, 1 e 3 de Junho de 1905 Translated by J. C. Branner and published in Economic Geology Nov.-Dec., 1905, I, No. 2, 134-142, under the title, "The geology of the diamond and carbonado washings of Bahia, Brazil." This was published in part in the Mining Magazine, XIII, 153-155. Feb., 1906. Abstract: Mineral Resources of the U. S. for 1905, 1330-1332. Washington, 1906.

DERBY, O. A.: Um fossil interessante do Museo Nacional (Psaronius brasiliensis). Jornal do Commercio, Rio de Janeiro, March 14, 1905. Also Diario de Noticias (da Bahia), March 23, 1905. (Results of Salm-Laubach in re Psaronius brasiliensis.)

DERBY, O. A.: A minha exoneração. O Commercio de São Paulo, de Fev. 3 e de Fev. 4, 1905 .

DERBY, O. A.: Um mappa interessante (de São Paulo, feito pelo Coronel João da Costa Ferreira no anno 1811.) Esstado de Sẫo Paulo, de Fev. 20 de 1905. São Paulo.

DERBY, O. A.: Manganese deposits of Nazareth, Brazil. Abstract: So headed in Engineering and Mining Journal, LXXX, 697, Oct. 14, 1905. This refers to the March Bulletin of the Dept. of Agriculture of the State of Bahia.

DERBY, O. A.: O Manganez em Nazareth. Boletim da Secretaria de Agricultura, etc., do Esstado da Bahia. V, 62-65. Jan.-Mar., Bahia, 1905. 
DERBY, O. A.: Notas geologicas sobre o Estado da Bahia, Boletim da Secre. taria da Agricultura, etc., do Estado da Bahia, VII, 12-31. Bahia, 1905.

DERBY, O. A.: Lavias diamantinas. Relatorio apresentado ao Dr. Secretario da Agricultura da Bahia. Revist. Inst. Geogr. e Hist. da Bahia, XI, No. 143-153. Bahia, 1905. Tambem no Boletim da Sec. de Agricultura, etc., do Estado da Bahia, V, 217-225. Bahia, 1905.

DERBY, O. A.: Manganez na Bahia. Jornal do Commercio, Rio de Janeiro, 17 de Abril de 1906.

DERBY, O. A.: Os primeiros descobrimentos de diamantes no Estado da Bahia. Revista do Inst. Geogr. e Hist. da Bahia, XII, No. 13, 143-151. Bahia, 1906. Tambem Boletim da Directoria de Agriculturu, etc., do Estado da Bahia, VII, 181-187. Bahia, 1906. In English: Brazilian Eng. and Mining Review, III, 81-83. Rio de Janeiro, June, 1906.

DERBY, O. A.: The Serra do Espinhaço, Brazil. Jour. Geol., XIV, 374-401. IIl. Chicago, July-Aug., 1906.

DERBY, O. A.: The sedimentary belt of the coast of Brazil. Jour. Geol., XV, pp. 218-237. 1 map. Chicago, 1907.

DERBY, O. A.: Um fossil interessante do Museo Nacional. Annuario do Dstado de Rio Grande do sul para o anno de 1908. Ills. Porto Alegre, 1907.

DERBY, O. A.: O regimen das chuvas nas regióes das seccas, Jornal do Commercio, Rio, 24 Março, 1906. Boletim da Directoria de Agricultura, etc., do Estado da Bahia, VII, 204-214/B Bahia, 1906, IX, 334-345. Bahia, 1907.

DESBERGER, FR. ED.: Ueber die Geralkarte von Südamerica. Geographische Anhang of Reise in Brasilien von Spix $u$. Martius, and of vol. III, 1-39. $4^{\circ}$. München, 1831.

DESCLOIZEAUX: Note sur le diamant noir. Annales des Mines, 5me sêrie, VIII, 304-306. Paris, 1855. Abstract: Amer. Jour. Sci., 1857, XXIV, 116-117.

DES CLOIZEAUX: Note sur la fibrolite d'Auvergne et la Haydénite de Baltimore, et sur de très petits diamants du Brésil. Bull. de la Soc. Minéral. de France, IV, 257-260. Paris, 1881. Diamants, 259-260. Abstract: Neues Jahrbuch für Mineral., 1883, 1, 6-7. (Referate.)

DES CLOIZEAUX: Note sur quelques formes nouvelles de l'euclase du Brésil. Bull. Soc. Minéral. de France, 1882, V, 317-320. Paris, 1882. Abstract: Neues Jahrb. für Mineralogie, 1884, I, 18-19. (Referate.)

DEVILIE, CH. SAINT-CLAIRE: Rapport sur plusieurs mémoires de M. Pissis, relatifs à la structure orographique et à la constitution géologique de l'Amérique du Sud, et en particulier, des Andes du Chili. Comptes Rendus de l'Acad. Sci., LVII, 32-37. Paris, 1863.

DEWEY, O. A.: Error for Derby, O. A., q. v., 1876.

DIETRICH, Baron DE: Description d'une pierre élastique. Observations sur la Physique, etc. XXV, 275-276. $4^{\circ}$. Paris, Au Bureau du Journal de Physique, 1784.

DIETZSCH, FERD.: Brasiliens Goldbergbau. Berg-u. Hüttenmännische Zeitung N. F. XXXVIII, 1879, 350-352; 369-371. Feb. 6, 1880. XXXIX Jahrg., 53-56; 27 Feb., 1880, 71-73 ; 12 Marz., 1880, 92-95; April 30, 1880, 145-147. Lelpzig, 1880.

DIEULAFAIT, IOUIS: Diamants et pierres precieuses. $12^{\circ} .130$ cuts. Paris, 1871.

DIEULAFAIT, LOUIS: Diamonds and precious stones. A popular account of gems. Translated from the French by Fanchon Sanford. New York, 1874. (Brazil, parts III and V.)

DIOGO DE SOUZA: V. SOUZA, D. DIOGO DE.

DODT, GUSTAVO IUIZ GUILHERME: Relatorio acerca da Exploração do Rio Parnahyba por ordem da Presidencia da Provincia de Piauhy. Annexo "O" do relatorio da Repartição dos Negocios da Agricultura, etc. $4^{\circ}$. Rio de Janeiro, 1872, 1-58. Considerạ̧ões geraes, 20-23. (He thinks 
the valley of the Parnahyba is Lower Trias; the hills are sedimentary outliers of the serras; he reports limestone, porphyry, salt, and fossil calamites.)

DöLI, E.: Zum Vorkommen des Diamants im Itakolumite Brasiliens und in den Kopjen Afrikas. Verhandlungen der $K$. KK. geologischen Reichsanstalt. 1880. No. 5, 78-80. Wien, 1880.

DöIL, E.: Ueber einige Pseudomorphosen aus Brasilien. Verhandlungen der K. K. geologischen Reichsanstalt. Wien, 1900, 148-150. Abstract: Neues Jahrbuch für Mineralogie, 1901, II, 6-7. Referate. Abstract: Zeitschrift für Krystallographie und Mineralogie (Groth), XXXVI, 640-641. Jeipzig, 1902.

DöLTER, C.: Ueber Spodumen und Petalit. Mineralogische und Petrographiche Mittheilungen (Tochermak's) Neue H'olge I, Wien, 1878. (Spodumen von Brasilien, 526-528.) Abstract: Zeitschrift für Krystallographie und Mineralogie (Groth), IV, 94-95. Leipzig, 1880.

DOMBRE, L. E.: Viagens do Engenheiro Dombré ao interior da provincia de Pernambuco em 1874 e 1875 . Recife, $1893,8^{\circ}, 86$ pages. (Letters containing many observations upon the geology of the interior addressed to M. V. Fournier, Director das Obras Publicas da Provincia de Pernambuco.)

DOM PEDRO D'ALCANTARA: V. ALCANTARA.

D'ORBIGNY: $\nabla$. ORBIGNY, ALCIDE D'.

D'OSERY, E.: Observations géologiques sur la constitution de quelques parties du Brésil. (Extrait d'une lettre a Elie de Beaumont.) Comptes Rendus de l'Acad. Sci., XIX, 673-676. Paris, 1844. Abstract: Neues Jahrb. für Mineral. 1845. 706-707.

D'OSERY: Catalogue général des échantillons de géologie par numéros formant une série continue a partir des roches de l'ile de Gorée, rédigé par M. d'Osery. Pages 359-429 de t. V de l'Histoire du Voyage de l'expedition dans les parties centrales de l'Amérique du Sud . . . dé Francis de Castelnau. $8^{\circ}$. Paris, 1851.

D'OSSAT, G. DE ANGELIs: Il disiophyllum Thildie n. sp. nel Para. Reale Academia dei Lincei, XII, 215-221. Illustrated. Roma, 1903. Abstract: Revue Critique de Paléozoologie, 10e année, No. 1, 73. Paris, Jan., 1906. (Fossil coral from Itaituba.)

DOUVILLE, H.: (Cretaceous of North Brazil in relation to other regions.) Bull. Soc. Géol. de France, III série, XXVIII, 234-235. Paris, 1900.

DRUMMOND, MENEZES DE: Notice sur les mines du Brésil. Journal des Voyages, Découvertes et Navigations Modernes, etc., XXXIII, 188-230; XXXIV, 286-316. Paris, 1827.

DRUMMOND, MENEZES DE: $\nabla$. ANDRADA.

DUFET, H.: Description d'un cristal d'oligiste. Bulletin de la Société Francaise de Minerálogie, XXVI, 60-63. Paris, 1903.

DUFReNOY: Rapport sur un Mémoire de M. Pissis, intitulé: Sur la position géologique des terrains de la partie australe du Brésil et les soulèvements qui à diverses époques, ont changé le relief de cetté contrée. Comptes Rendus de l'Acad. Sci., XVII, 28-38. Paris, 1843. Abstract: Neues Jahrbuch für Mineralogie, 1844, 630-633.

DUFReNOY: Compact diamond from Brazil. Amer. Jour. Sci., 2d series, VII, 433. New Haven, 1849.

DUFRENOY: On a large diamond from the district of Bagagem, Brazil. Amer. Jour. Sci., 2d series, XIX, 288 and 359. New Haven, 1855.

DUFRENOY: Note sur un cristal de diamant provenant du district de Bagagem, au Brésil. Comptes Rendus de l'Acad. Sci., XL, 3-5. Paris, 1855. Abstract: Neues Jahrbuch für Mineralogie, 1856, 841-842.

DUFRENOY: Ueber einen Diamantkrystall aus dem Districte Bagagem in Brasilien. Poggendorff Annalen der Phys. u. Chemie, XCIV, 475-478. I.eipzig, 1855. 
DUFRenoY, A.: Traité de minéralogie. Paris, 1856. (On Brazilian diamonds, II, 93-101.)

DUFRENOY: v. BRONGNIART, DUFRENOY et BEAUMONT.

DUNLOP, CHARLES: Brazil as a field for emigration, its geography, climate, agricultural capabilities, etc. $32 \mathrm{pp}$. $8^{\circ}$. London, n. d. (Physical features, 3-6 ; mineral resources, 10-11.)

DUNSTAN, W. R.: See Imperial Institute.

DUPRE, LEANDRO: Memoria sobre a fabrica de ferro de S. João de Ipanema. Annaes da Escola de Minas de Ouro Preto, 1885, No. 4, 51-90. Copied in Revista de Engenharia, No. 147, 14 de Outubro de 1886, VIII, 217-219; No. 148, 28 de Out. de 1886, VIII, 230-234; No. 149, 14 de Nov. de 1886, VIII, 245-247. Ill. Rio de Janeiro, 1886.

DUPRA, Junior, LEANDRO: Estudo geologico e mineralogico da regiño E. de Ouro Preto, comprehendida entre aquella cidade a provoação do Taquaral e o Rio do Carmo. Archivos do Museu Nasional do Rio de Janeiro, III, 11-16. $4^{\circ}$. Rio de Janeiro, 1878.

DURAND, M. L'Abbe: Essai sur l'orographie du Brésil. Association Francaise pour l'Avancement des sciences, Compte Rendu de la 3me session, 998-1004. Paris, 1875.

DURAND, M. L'Abbe: La province brésilienne de Minas Geraes (Mines Générales) sous les rapports industriel, agricole et colonial. Association Francaise pour l'A vancement des Sciences, Compte Rendu de la 2me session, 927-934. Paris, 1874.

D'URVILIE, DUMONT: Voyage autour du monde publie sous la direction du Contre-Amiral Dumont D'Urville. Nouvelle édition, revue et corrigée. Tome 1er, $8^{\circ}$. Paris, 1857. Notes on Brazil, 42-50.

DUASEN, P.: Sur 1 flore de la Serra de Itatiaia, Brésil. Arichivos do Musen Nac., XIII. Rio de Janeiro, 1905. (Geology, 5-7.)

ECKENBRECHER, CURT.: Untersuchungen über Umwandlungsvorgänge in Nephleingesteinen. Tschermak's Miner. u. Petrogr, Mittheilungen, 1880, N. F. III, 1-35. Wien, 1881.

EDDY, HENRY: On the mines of the province of Rio Grande do Sul, Brazil. Trans. Royal Geol. Soc. Cornwall, X, pt. V, 157-160. 8. Penzance, 1883.

EHRENREICH, PAUL: Beiträge zur Geographie Central-Brasiliens. Zeitschrift der Gesellschaft für Erdkunde zu Berlin, XXVI, 167-191. Berlin, 1891; XXVII, 121-152, with maps, Berlin, 1892. Abstract: Scottish Geographical Magazine, IX, 44-46. Edinburgh, 1893.

FIGENMANN, CARL H.: The fresh-water fishes of South and Middle America. Popular Science Monthly, LXVIII, 515-530. New York, June, 1906.

ELfMENÇON, Dr.: Considérations abrégées sur la géognosie du district des diamants du Brésil par Le Docteur Elémencon. Annales de la Société Linneene de Lyon. 20 p. Lyon, Imp. de Louis Perrin, 1836. (The pages of the volume are not numbered consecutively, and there is no index or volume number. The name Elémençon is not in the list of members, but Dr. Toussaint Clemançon was Secretary-General and was titulary member from 1825. The name should probably be Clêmançon.-J. C. B.)

ELVAS, BISPO D': Memoria sobre minas de ferro. Lisboa, 1810.

ENGELHARDT, MORITZ VON: Die Lagerstätte der Diamanten. (Diamonds of Brazil and the Urals.) Pogg. Annalen der Phys. u. Chemie, $\mathrm{XX}, 524-$ 539. Leipzig, 1830. Notice: Jahres-Bericht über die Fortschritte der. physischen Wissenschaften von Jacob Berzelius, XI, Jahrg., 203. Tü̈bingen, 1832.

FRARD: I.e carbon et ses composes. Paris, 1906. (v. Reis.) 
ERMAN: Beiträge zur Monographie des Marekanit, Turmalin und Brasilianischen Topas in Bezug auf Elektrizität. III Brasilianischer Topas. $A b$ handl. der Koniglichen Akad. der Wissensch. zu Berlin, 1829, 57-62. Berlin, 1832. Notice: Neues Jahrbuch fïr Min., 226. 1834.

FRMAN, A: Ueber einige bisher nicht beachtete Tertiar-Gesteine aus der Umgegend von Rio de Janeiro. Archiv fïr Wissenschaftliche Kunde von Russland. (Erman's Archiv.), XIV, 16-23. Berlin, 1854.

ESCHWFGE, GUILHERME, BARÃO DE: Extracto de huma memoria sobre a decadencia das minas de ouro da Capitania de Minas Geraes, e sobre varios outros objectos montanisticos. Mem. Acad. Sci. Lisboa, IV, Pt. II, 65-76. Lisboa, 1811.

ESCHWEGE, Baron d': Idées génerales sur la constitution géologique du Brésil. Annales des Mincs. 2me série, II, 238-240. Paris, 1817.

ESCHWEGE, GUITHFRME, BARÃO DE: (Galena do Abaeté.) (Fabrica de ferro.) Cartas do Barão de Eschwege aos Governadores Conde da Palna e D. Manoel de Portugal e Castro, 1713 e 1720. Revista do Archivo Publico Mineiro, Anno II, fasciculo 4, 749-752. Ouro Preto, Out. a Dez, 1897.

ESCHWEGE, GUIIHERME, BARÃO DE: Noticias e reflexões estađisticas a respeito da Provincia de Minas Geraes. Memorias da Academia Real das Sciencias de Lisboa, IX, 1-27. Lisboa, 1825. Republished in the Revista do Archivo Publico Mineiro, Anno IV, fasciculos III e IV, 1899, 737-762. Bello Horizonte, 1900.

ESCHWEGE, G. C. (sic.) D': Voyage de Rio de Janeiro au Comarca d'Ilha Grande fait en 1810. Extrait du Journal von Brasilien, Nouvelles Annales des Voyages de la Géographie et de l'Histoire (etc.), XX, 289-328. $8^{\circ}$. Paris, 1823 .

ESOHWEGE, W. VON: Mineralogische Nachrichten aus Brasilien. Ueber das Verkommen des Gediegen-Goldes zu Minas Geraes in Brasilien. Neue Jahrbücher der Berg- und Hüttenkunde (Von K. E. von MolI), III, 321-340. Nürnberg, 1815. Abstract: Taschenbuch für Mineralogie von Leonhard. IIer Jahrgang, 551-552. Frankfurt a. Main, 1817.

BSCHWEGE, W. VON: Physikalische und bergmännische Nachrichten aus Brasilien. Annalen der Physik von I. W. Gilbert. LIX, 117-139. Leipzig, 1818.

ESCHWEGE, W. I. VON: Journal von Brasilien, oder vermischte Nachrichten aus Brasilien, auf wissenschaftlichen Reisen gesammelt. Mit einem Plane und Kupfern. Weimar, 1818, 12 , vol. I, $\mathrm{XV}+242$ pages, map and ill. Vol. II, XII + 304 pages, map and ill.

ESCHWEGE, W. I. VON: Observations sur la manière de voyager dans l'intérieur du Brêsil et tableau de cette partie du pays. (Trađuit de l'allemand.) Nouvelles Annales des Voyages, III, 99-120. Paris, 1819.

ESOHWEGE, W. L. VON: Nachrichten aus Tortugal und dessen Colonieu, mineralogischen und bergmännischen Inhaltes, herausg. von J. C. L. Zincken. Ein Seitenstück zum Journale von Brasilien. $8^{\circ}$, ill. Braunschweig, 1820.

ESOHWEGE, VON: Ueber einige merkwürdige brasilianische Gebirgs-Formation. Annalen der Physil und der Physikalischen Chernie, von L. W. Gilbert. V, 411-424. Leipzig, 1820.

ESCHWEGE, VON: Verkommen des elastischen Sandsteines in Brasilien. Annalen der Physik, von L. W. Gilbert, neue Folge, XXVIII, 99-101. Leipzig, 1818. Review: Taschenbuch für Mineralogie, von Leonhard, 15er Jahrgang, 885-886. Frankfurt a. M., 1821.

ESCHWEGE, VON: Auszug aus einem Schreiben . . . aus Villa Rica. (Gold-washing and iron manufacture.) Neue Jahrbücher der Berg- und Hüttenkunde (Von Moll's), IV, 270-273. Nürnberg, 1821.

BSCHWHGE, VON: Geognostische Beobachtungen über einen Theil der Capitanie S. Paulo (2 vols.?). Review: Taschenbuch fïr Mineralogie von Leonhard. 16er Jahrgang. 193-206. Frankfurt a. M., 1822. 
ESCHWEGE, W. I. VON: Geognostisches Gemälde von Brazilien und dem wahrscheinlichen Muttergestein der Diamanten. $8^{\circ} .64$ pages, with map. Weimar, 1822. Review by Aug. de St. Hilaire in Bulletin Général et Universal des Annonces et des Nouvelles Seientifiques, No. 10, 39. Paris, Octobre, 1823. Review: Leonhard's Mineralogisches Taschenbuch für das Jahr., 1824. 3e. Abth., 670-672. Frankfurt a. Main, 1824.

ESCHWEGE, W. I. VON: Esquisse géognostique du Brésil, suivie d'une dissertation sur la gangue originaire du diamant. (Ext. Traduit de l'allemand par M. Combes.) Annales des Mines, VIII, 401-430. Paris, 1823. Abstract: Bulletin des Sci. Nat. et de Géologie, 132-136. $8^{\circ}$. Paris, Oct., 1824.

ESCHWEGE: (Notes on the geognosy of Brazil. Matrix of the Brazilian diamond.) Edinburgh Philosophical Journal, IX, 200-202. Edinburgh, July, 1823. Abstract: Bulletin des sci. Nat. et de Géologie, Janvier, 1824, I, 14-15. Paris, 1824. This abstract under the title "Geologia do Brazil" is given in Geologia Elementar, etc., por N. Boubee, pages 39-40 of the Additamento. Rio de Janeiro, 1846.

ESCHWEGE, L. W. VON: Brasillien die neue Welt, in topographischer, geognosticher, bergmännischer, naturhistorischer, politischer und statistischer Hinsicht, während eines elfjähringen Aufenthaltes, von 1810 bis 1821 mit Hinweisung auf die neueren Begebenheiten, beobachtet von $\mathrm{L}$. W. von Eschwege. In zwei Theilen mit Kupfern. Braunschweig, 1830. $8^{\circ}$, vol. I, $X+252$ pp.; vol. II, $X+183$ pp. (The title page on each volume gives the author's name as $L . W$. von Eschwege; but the dedication is signed $W . L$. von Eschwege.)

ESCHWEGE, W. v.: Höhenpuncte in par. Fuss nach den barometrischen Beobachtungen von W. v. Eschwege, v. Spix und v. Martius, pp. 39-40 of the Geographischer Anhang at the end of vol. III of Reise in Brasilien . . von Dr. Joh. Bapt. von Spix u. Dr. Carl Friedr. Phil. von Martius. München, 1831.

ESCHWEGE, W. L. VON: Beiträge zur Gebirgskunde Brasiliens. Mit vier petrographisch-geognostischen Karten und Profildurchschnitten, $8^{\circ}, \mathrm{XV}+$ 488 pp. Berlin, 1832. Page XV has the title as follows: Beiträge zur Gebirgskund Brasiliens aus den Reisen der Herien v. Spix und v. Martius zusammengestehlt und mit Anmerkungen begleitet von W. I. von Eschwege.

ESCHWEGE, W. I. VON: Pluto Brasiliensis. Wine Reihe von Abhandlungen über Brasiliens Gold-, Diamanten und anderen mineralischen Reichthum, über die Geschichte seiner Entdeckung, über das Vorkommen seiner Lagerstätten, des Betriebs, der Ausbeute und die darauf beziigliche Gesetzgebung u. s. w. Berlin, G. Reimer, $1833,8^{\circ}$, XVIII + 622 pages.

Cap. 5, parte 3a, traduzido por Rodolpho Jacob, e publicado na Revista do Archivo Publico Mineiro. Anno II, fasciculo 4, 611-672. Ouro Preto, Out. a Dez., 1897.

Cap. 2, parte I, mesmo. Anno III, fas. II, 1898, 433-463. Bello Horizonte, 1898.

Cap. I, parte III, mesmo, Anno III, fas. III e IV, 1898, 519-577. Bello Horizonte, 1898.

ESCHEWEGE: Bosquejo geognostico do Brasil, com huma dissertação sobre a matriz dos diamantes. $2^{\circ}$ Additamento a "Geologia Elementar" de Nereo Boubee, 2a parte, 35-39. Rio de Janeiro, 1846. Translation of the "Esquisse Géognostique" from the Annales des Mines, q. v.

ESCHWEGE, Baron v.: Ueber das Gebirge von Cintra (Auszug aus einem Briefe des Generals v. Eschwege an den Hrn. Classen-secretär.) Gelehrte Anzeigen: Bulletin der $k$. bayer. Akademie der Wissenschaften. München, 1846, part I, Nos. 92 and 93, 739-750. Brazil, 747-750.

ESCOLA DE MINAS DE OURO PRETO: Analyses feitas nos laboratorios de chimica e docimasia da Escola de Minas de Ouro Preto. $1^{\circ}$, ouro; $2^{\circ}$, chumbo e prata; $3^{\circ}$, ferro $; 4^{\circ}$, calcareos $; 5^{\circ}$, carvão. (The names of the analysts are not given except as noted below.) Annaes da Escola de Minas de Ouro Preto. No. 1, 129-150. Rio de Janeiro, 1881. 
Aualyses feitas nos laboratorios de chimica e docimasia da Escola de Minas de Ouro Preto. $1^{\circ}$, ferro $; 2^{\circ}$, chumbo $; 3^{\circ}$, ouro $; 4^{\circ}$, substancias diversas (Das substancias diversas e No. 1 por de Bovet, e No. 2 por Costa Sena; as analyses de ferro são por D. Rocha). Annaes da Escola Minas de Ouro de Preto, No. 2, 133-143. Ouro Preto, 1883.

The second article is reprinted in the Auxiliador da Industria Nacional No. 7 , Julho de 1883, II, 161-165.

The following are republished in the Revista de Engenharia, V, 28 de Agosto de 1883. Minerios de ferro $217 ; 14$ de Set. de 1883, 239-240, minerios de chumbo, 14 de Set. de 1883,240 ; minerios de ouro, 14 de Set. de 1883,$240 ; 28$ de Set. de 1883, 255, IV; substancias diversas, 14 de Out. de 1883,272 . Rio de Janeiro, 1883.

ESPINDOLA, THOMAZ DO BOM-FIM: Geographia Alagoana on descripção physica, politica e historica da provincia das Alagôas. 2a edição. Maceió, Typ. do Liberal, 1871 . (Reino mineral, 91-92 ; mentions localities of limestones, marls, flint and oil shales.)

ETHERIOGE, R.: Notes on the mollusca collected by C. Barrington Brown, from the Tertiary deposits of Solimões and Javary rivers, Brazil. (Appendix to Brown's paper.) Quart. Jour. Geol. Soc., XXXV, 82-88; one plate. London, 1879 .

EUSTIS, W. C.: Analysis of Gibbsite from Marianna, Province of Minas Geraes, Brazil. The Chemical News, XLVIIt, 98. London, 1883. Abstract: Zeitschrift für Krystallog`aphie und Mlineralogie (Groth), IX, 630. Leipzig, 1884.

FUTROPE, L.: Guyane française. Carte géographo-gêologique, dessinê d'après les reconnaissances et observations faite de 1867 à 1878 par le bureau du cadastre de Cayenne. Echelle, I : 400,000. Paris, 1879.

EVANS, J. W.: The geology of Matto Grosso, particularly the region drained by the upper Paraguay. - Quart. Jour. Geol. Soc., Feb., 1894, L, 85-104. Map and plate. London, 1894. Abstract: Natural Science, IV, 225-226. London and New York, Jan.-June, 1894.

EVANS, J. W.: The rocks of the cataracts of the River Madeira and the adjoining portions of the Beni and Mamoré. Quarterty. Journal of the Geological Society, LXII, 88-124. Illustrated. London, Feb., 1906. Abstract: Nature, LXXIII, 141. London, Dec. 7, 1905.

EYRI'S, J. B. B.: จ. MAWE v. MAXIMILIEN.

FARRINGTON, OLIVER C.: Gems and gem minerals. $4^{\circ} . \mathrm{XII}+229 \mathrm{pp}$. (Illustrated.) Chicago, 1903. (Brazilian minerals, 75; 83; 104; 106 ; $111 ; 121 ; 124 ; 142 ; 143 ; 145 ; 154$.

FAUSTO DE SOUZA: $\nabla$. SOUZA, A. FAUSTO DE:

FEIJó, JOÃO DA SILVA: Memoria sobre mineraes de ferro de Cangaty do Xoró na Capitania de Ceará escripta no anno de 1814. Annexo ao Relatorio do Ministro da Agricultura, Rio de Janeiro, 1864. 8 pp. Partly republished in Chorographia da Provincia do Ceará por José Pompeu de A. Cavalcanti, 64-66. Rio Janeiro, 1888.

FELDNER, WILF. CHRIST. GOTTHELF v.: Reisen durch mehrere Provinzen Brasiliens. Aus seinem nachgelassenen Papieren. 2 vols., $12^{\circ}$ Erster 'Theil. Allegemeine Uebersicht XXVIII +182 pages. Zweiter 'Theil. Reisebemerkungen. (260 pages.) Leignitz, 1828.

FELICIO DOS SANTOS: $\nabla$. SANTOS, F.

FERNANDES DA SILVEIRA: v. SIIVEIRA, ANTONIO F. DA.

FERNANDES, Jr., XISTO PIO: Aquamarines and tourmalines at Arassuahy in Minas Geraes. Brazilian Engineering and Mining Review, II, 42. Rio, Mar., 1905; II, 52-53.

FERNANDES PINHEIRO: v. PINHEIRO, J. F. F.

FERRAND, PAULO: Industria de ferro no Brazil. Provincia de Minas Gernes. Revista de Engenharia, $\mathrm{V}, 237-239$. Chart. Rio de Janeiro, 14 de Setembro, 1883 . 
FERRAND, PAUL: A Industria de ferro no Brazil. (Datado Ouro Preto, Abril de 1884.) Annaes da Escola de Minas de Ouro Preto, 1885, No. 4, 167-188. Rio de Janeiro, 1885.

FERRAND, PAUL: (Forms of iron deposits in Minas.) Revista de Engenharia, No. 250, de 14 de Janeiro de 1890, XIII, 345. From the Jornal do Commercio. Rio de Janeiro, 1890.

FERRAND, PAUL: Ouro Preto et les mines d'or (Brésil.) Le Génie Oivil; Revue générale heblomadaire des Industries francaises et étrangères. Paris, 1890-1893. (Ill.) XVI, No. 13 (Jan. 20, 1890), Nos. 14-19, 21, pp. $283,303,325,338,354,389,421$; XVII, Nos. 1, 2, pp. 8, 21 ; XIX, Nos. 14, 15, 221, 239; XX, No. 26, 427; XXIII, Nos. 21, 22 (Sept. 30, 1893), pp. $334,351$.

FERRAND, PAUL: Exploitations auriféres de Minas Geraes. Revista Industrial de Minas Geraes. Anno. I, 6-11. Ouro Preto, 15 de Outubro, 1893. Revue Unireselle des Mines, $3^{\circ}$ ser., XXVIII, 192-204. Liége, 1894. Abstract: Journal of the Iron and steel Institute, XLVI, 291. London, 1895.

FERRAND, PAUL: L'or a Minas Geraes, Brésil. ttude publiée par les soins de la commission de l'Exposition preparatoire de l'état de Minas Geraes a Ouro Preto, à l'occasion de l'exposition miniére et métallurgique à Santiago, Chile, en 1894. Ouro Preto, 1894, 2 vols. in- $8^{\circ}, 159$ et 135 pages (avec figures dan le texte, 2 cartes et un tableau.) Abstract: Neues Jahrbuch für Mineralogie, 1896, I, 270 (Referate).

The same is published in Portuguese in the Revista de Engenharia as far as p. 60 of vol. I of the original French edition, under the title Ouro Preto $e$ as minas de ouro, with ills., in the following nos.: No. 174, 28 de Nov. de 1887, IX, 261-263; No. 177, 14 de Jan. de 1888, X, 1-4; No. 183, 14 de Abril de 1888, X, 76-77; No. 267, 14 de Outubro de 1891, XIII, 581582 ; No. 268, 28 de Out. de 1891, XIII, 593 ; No. 269, 14 de Nov. de 1891, XIII, 605-606 ; No. 270,28 de Nov. de 1891, XIII, 617-618; No. 271, 14 de Dez. de 1891, XIII, 630. Rio de Janeiro, 1887-1891.

FERRAND, PAUL: Industria do ferro, seu estado actual no Brazil. Revista Industrial de Minas Geraes. Anno I, No. 5, 102-106: Ouro Preto, 15 de Fev., 1894.

FERRAND, PAUL: L'or a Minas Geraes (Notice in). Revue Universelle des Mines, de la Métallurgie, etc., XXVIII, 216, 1894. XXX, 106, Liége et Paris, 1895.

FERRAZ, LUIZ PEDREIRA DO COUTTO: Instrucções para a commissão scientifica encarregada de explorar o interior de algumas provincias do Brazil menos conhecidas. Revista Brazileira, I, 241-279. Rio de Janeiro, 1857. (Instructions on geology, 243-249.) Also published in Archivos da Palestra Scientifica do Rio de Janeiro, I, 175-181. $4^{\circ}$. Rio de Janeiro, 1858. These instructions are published in the Jornal do Commercio, Rio de Janeiro, Nov. 20, 22, 24, 1856.

FERRAZ, IUIz: The Palma gold-deposit, Minas. Brazilian Mining Review, I, 173-174. Rio de Janeiro, Feb., 1904. Separate under the title : Report on the auriferous deposits of Palma, Minas Geraes. 8 pp. Rio de Janeiro, 1904.

FERREIRA, FRANCISCO IGNACIO: Diccionario geographico das minas do Brazil, Concatenação de noticias, informações e discripç̃es sobre as minas extrahidas de documentos officiaes, memorias, historias, revistas, diccionarios, cartas geographicas, roteiros, viagens, exploraçōes de rios, etc. $8^{\circ}$. 755 pages. Rio de Janeiro, 1885 . (This is an important compilation, and contains extracts from most of the works on mining geology up to the date of its publication. Many of the works quoted are rare and inaccessible.)

FERREIRA, PENNA: v. PENNA, D. S. F.

FEUCHTWANGER, LEWIS: A treatise on gems, in reference to their practical and scientific value . . . accompanied by a description of the most interesting American gems and ornamental and architectural materials. $8^{\circ}, 162$ pp. Ill. New York, 1838. Brazil, 55-59; 74-75; 78-80, etc. 
FEUCHTWANGER, IEWIS: A popular treatise on gems, in reference to their scientific value . . . with a description of the elements of mineralogy, etc. Ill. 528 pp. New York, 1872. Diamonds, 183-214; Brazil, 190-193.

FILHO, JOAOO BAPTISTA DE LACERDA: V. LACERDA FILHO, J. B. DE.

FISCHER, C. A.: Tafereelen van Brazilië door C. A. Fischer schrijver der Tafereelen van Valentia, Madrid enz. Le Haarlem, 1819. (Minas Geraes, 18-36.)

FISCHER, H.: Ueber Nephritbeile aus Brasilien und Venezuela. Neues Jahrbuch fiir Mineralogie, 1884, II, 214-217. Briefliche Mittheilungen. Stuttgart, 1884.

FITZ ROY, Captain: Extract of a letter from Captain Fitz Roy of H. M. Sloop "Beagle," on the subject of the Abrolhos Bank. Journal of the Royal Geographical Society of London, II, 315-316. London, 1832.

FIFTCHER, I.: [Hussak's Brazilite.] Appendix to an article entitled "On Baddeleyite (native zirconia), a new mineral from Rakwana, Ceylon." Mineralogical Magazine and Journal of the Mineralogical Society, X, 158160. London, 1894.

FLORENCE, G.: Nota sobre a stolzita e schoelita (Soumidoro) do Itacolumy de Marianna. Annaes da Escola de Minas. No. 6, 83-90. Ouro Preto, 1903.

FLORENCE, G.: Notas Geologicas sobre o Rio Paraná. Exploração do Rio Parana. Com. Geog. e Geol. de S. Paulo. Fol. pp. 7-8. S. Paulo, 1906.

FLORENCE, G.: Notas geologicas sobre o Rio Tieté. Exploração do Rio Tieté. Com. Geog. e Geol. de S. Paulo. Fol. pp. 9-15. S. Paulo, 1907.

FLORENCE, HERCULES: Esboço da viagem feita pelo Sr. de Langsdorff no interior do Brasil, desde Setembro de 1825 ate Março de 1829. Escripto em original Francez pelo $2^{\circ}$ desenhista da Commissão Scientifica, Hercules Florence. Traduzido por Alfredo d'Escragnolle 'Taunay. Revista Inst. Hist., XXXVIII, parte I. Notes on the Geology of Matto Grosso, 449-469. Parte II, 262-267. Rio de Janeiro, 1875.

FLORENCE, W.: Notas chimicas (on ninerals of the Bendigo meteorite). Appendix to Derby's "Estudo sobre o meteorito de Bendigó." Archivos do Museo Nacional do Rio de Janeiro, XII, 174-184. Rio de Janeiro, 1896.

FLORENCE, W.: Darstellung mikroskopischer Krystalle in Löthrohrperlen. Neues Jahrbuch für Mineralogie Geologie und Palaeontologie, 1898, II, 102-146, with 4 plates and 12 textfigures. Stuttgart, 1898.

FLORENCE, W.: (Analyses of "favas" from Brazil), quoted by Geo. F. Kunz, 21st Ann. Rep. U. S. Geol. Sur., Part VI, continued, 430. Washington, 1901. And p. 16 of separate from Hussak's "Mineralogische Notizen," q. v.

FLORENCE, W.: Ueber Stolzit und Scheelit von Marianna de Itacolumy im Statte Minas Geraes (Brasilen). Gentralblatt für Mineralogie, Geologie und Paleontologie, no. 23, 725-728. Stuttgart, 1903. Abstract: Zeitschrift für Krystallographie und Mineralogie, XLI, 648. Leipzig, 1906.

FOETTERLE, FRANZ: Die geologische Uebersichtskarte des mittleren Theiles von Süd-Amerika. Mit einem Vorworte von W. Haidinger. Wien, 1854 (pp. 22, geol. map of $\mathrm{S}$. Amer.). The accompanying niap by Francisco Foetterle is in Portuguese; it was constructed for von Martius. The original of this geological map is in the library of the Geological Society of London. Abstract: Neues Jahrbuch für Mineral., 1855, 90-91. Stuttgart, 1855.

FOFTTERLE, FRANZ: Die geologie von Süd-Amerika. Petermann's Mittheilungen, 1856, 187-192. Gotha.

FONSECA, JOAO SEVERIANO DA: Viagem ao redor do Brazil, 1875-1878. Vol, I, illustrated, royal $8^{\circ}, 399$ pages. Rio de Janeiro, 1880 . (The outside cover bears the date 1881.) Vol. II, Rio de Janeiro, 1881. Contains map of Rio Guaporé and many brief notes on the geology and geography of the Upper Paraguay and Matto Grosso. 
FONSECA, JOÃO SEVERIANO DA: A Gruta do Inferno na Provincia de Matto Grosso, junto ao forte de Coimbra. Revista do Instituto Historico XLV, Parte II, 21-34. Rio de Janeiro, 1882.

FONSECA, JOSE GONCALVES DA: Noticia da situação de Matto Grosso e Cuyaba: Estado de umas e outras ninas e novos descobrimentos de ouro e diamantes. Revista Inst. Hist., Tomo XXIX, Parte I, 352-390. Rio de Janeiro, 1866.

FONTENAY: See Jannettaz.

FONTENELLE, JOSt FREIRE BEZERRIL: 'The State of Ceara. Brief notes for the Exposition of Chicago as authorized by the Governor of Ceara, Brazil. Chicago, 1893, pp. 30-34, notes on the geology and mineralogy from Derby, Capanema Coutinho, Feijo and Gardner. Physical aspects, 12-30. Ill.

FORBES, WILIIAM A.: Eleven weeks in northeastern Brazil. In "Ihe collected scientific papers of the late William Alexander Forbes," 242-252. $8^{\circ}$. London, 1885. This paper is from Ibis, 1881, 312-326. It has a few notes on physical features and geology of the region about Recife, Garanhuns and Parahyba.

FORTES, J. B.: Santa Maria da Bocca do Monte, cidade e municipio. Annuario do Estado do Rio Grande do Sul para o anno de 1902, publicado sob a direção de Graciano A. de Azambuja. 12 ${ }^{\circ}$, 155-162. Porto Alegre, 1901. Notes on the geology.

FOUQUE: Contribution à l'êtude des feldspaths des roches volcaniques; albite de Minas Geraes. Bull. Soc. Française de Minéral., XVII, 390. Paris, 1894.

FOURNIER, VICTOR et BERINGER, EMIIE: Mémoire sur le port du Recife (Pernambuco, Brésil). Bijbladen van Het Tijdschrift van het Aardrijlkskundig Genootschap Gevestigd te Amsterdam onder Redactie van Prof. G. M. Kan en N. W. Posthumus. No. 8. Amsterdam and Utrecht, 1881, $4^{\circ}, 20 \mathrm{pp}$., with chart. Notes on geographic changes:

FOURNIE, VICTOR: Relatorio apresentado ao Exem. Senhor Presidente da Provincia de Pernanbuco pelo Engenheiro Victor Fournie, Director das Obras Publicas em 31 de Janeiro de 1876. $4^{\circ}$. Pernambuco, 1876. (Estudos graphicos e serviços topographicos, pp. 6-13; geologia, 14-16.)

FOX, DANIEL M.: Description of the line and works of the São Paulo railway in the Empire of Brazil. Minutes of Proceedings of the Institution of Civil Engineers, XXX, 29-77. London, 1870. Geology, 43-44.

FRANK, EMANUEL PAULO: Minas de carvão de S. Jeronymo. With map of the mines. Revista de Engenharia. No. 219, XI, 220-225. Rlo de Janeiro, 14 de Out., 1889.

FRANKIIN DA SILVA: $\nabla$. SILVA, J. FRANKIIN DA.

FRECH, FRITZ: Lethaea Geognostica, I Theil. Lethaea palaeozoica. 2 Band (Die Dyas) 4 Tieferung, 618-621. $4^{\circ}$. Stuttgart, 1902. The Permo-Carboniferous of Rio Grande do Sul, Santa Catharina, etc.

FREDEL, C.: Nouvelles formes du Zircon. Annales des Mines, 1856, p. 629.

FREITAS, A. DE PAULA: Recursos da cidade do Rio de Janeiro em pedras naturaes de construção. Revista do Inst. Polytechnico, X, 1-15; XI. Rio de Janeiro, 1878.

FREITAS, FRANCISCO JOSE DE: Noticia geologica da região situada entre Paracary e o Maecurú. Revista de Engenharia, II, No. 2, 10-11. Rio de Janeiro, Fev. 15, 1880. Also separate 16mo, 15 pp. Rio de Janeiro, 1880.

FREIRE, FELISBELLO FIRMO DE OLIVFIRA: Historia de Sergipe, 15751855. Rio de Janeiro, 1891. Cap. IV, geologia de Sergipe resume from Liais and Hartt, pp. LIX-LXVI.

FREYCINET: See Gaudichaud.

FREYREISZ, GFORGE WILHELM: Beiträge zur näheren Kenntnisz des Kaiserthums Brasilien nebst einer Schilderung der neuen Colonie Leopoldina, etc. Erster Theil. Frankfurt-am-Main, 1824. Mineralreich, 22-36. 
FRIEDEL, M.: Note sux deux cristaux de zircon basés. Annales des Mines. 5me sér., IX, 629-630. Paris, 1856. Sur cristilux provenzint de Serro Frio.

FRIEDEL, CHARLES: Sur des cristaux de soufre contenus dans une pyrite épigène. Bulletin de la société Franģaise de Minéralogie, XV, 123. Paris, 1892.

FRIZ, W.: Ueber Manganerzindustrie Brasiliens. Zeit. für Prakt. Geol., XII, 414-416. Berlin, 1904.

FUCHS, ED., et LAUNAY, L. DE: Traité des gîtes mineraux et metallifères. Recherche, etude et conditions d'exploitation des mineraux utiles, description des principales mines comnues, usages et statistique des métaux. Cours de gêologie applionée de l'école Supérieure des Mines. Paris, 1893,2 vols. in $8^{\circ}$ T. I, CXI +823 pages. Tome II, 1015 pages. Diamants du Brésil, I, 23-27. Gísements aurifères du Brésil, II, 938-941.

FUNKE, ALFRED: Rio Grande do Sul. Natur., LI, 25-27, 44-45, 73-75, 85-8i, Halle, 1902.

FURNISS, H. W.: Carbons in Brazil. (U. S.) Consular Reports, LVIII, No. 219, 604-606. Washington, Dec., 1898.

FURNISS, H. W.: Monazite concession in Brazil. (U. S.) Consular Reports, LX, 143-145. Washington, 1899.

FURNISS, H. W.: Manganese mining in Bahia. (U. S.) Consular Reports, LXI, 266-268. Washington, Oct., 1899.

FURNISS, H. W.: Diamonds and carbons in Bahia. (U. S.) Consular Reports, LXX, 145-154. Washington, Oct., 1902. Dated Bahia, June 23, 1903. This paper was first issued in the "Advance Sheets of the Consular Reports," No. 1423, Aug. 20, 1902. Also in Brazilian Mining Review, I, 94-99. Rio de Janeiro, July, 1903. Also in Mining Journal, LXXIT, 1476-1477. London, Nov. 1, 1902.

FURNISS, H. W.: (Diamonds in Bahia.) Quoted in Mineral Industry, XI, 246-247. New York, 1903. Quoted by G. F. Kunz, in Mineral Resources of the United States, in 1902, 17-24. Washington, 1903.

FURNISS, F. W.: (Minerals, mines and mining in Bahia.) (U. S.) Consular Reports, LXX, 96-97. Washington, 1902.

FURNISS, H. H.: Manganese in Bahia. American Manufacturer, LXV, 16 í.

FURNISS, H. W.: Diamonds and carbons in Brazil. Popular Science Monthly, LXIX, 272-280. $8^{\circ}$. Ill. New York, Sept., 1906. Excerpts from this article: Engineering and Mining Journal, Nov. 3, 1906, 821. Excerpts and ills. in Mine and Quary, I, no. 3. Chicago, Nov., 1906, pp. 64-69.

GABAGLIA, G. R.: See Machado e.

GABAGLIA, GIACOMO RAJA, e MANOEL ANTONIO VITAL DE OLIVEIRA: Parecer relativo a memoria do Sr. Conde de la Hure: "Exploration du Rio Parahyba do Sul de sa vallée e de quelques points avoisinants entre Desengano e Entre-Rios." Revista do Inst. Hist., XXVIII, parte II, 305-309. Rio de Janeiro, 1865.

GABB, W. M.: Descriptions of some new species of Cretaceous fossils from South America in the collection of the Academy. Proceedings of the Academy Nat. Sci. of Philadelphia, 1860, 197-198, and plate. Philadelphia, 1861.

GABB, W. M.: Descriptions of fossils from the clay deposits of the upper Amazon. American Journal of Conchology, IV, 197-200, plate. Philadelphia, 1868.

GABRIEL SOARES DE SOUZA: $\nabla$. SOUZA.

GALVÃO, FELIPPE RIBEIRO: Diamantes em Matto Grosso. Jornal do Commercio, Rio de Janeiro, 14 de Abril de 1905. In English: Brazilian Eng. and Mining Review, III, 145-146. Rio de Janeiro, Oct., 1906.

GALVÃo, OLYMPIO EUZEBIo DE ARROXELLA: Succinta descripção do municipio de Porto Calvo. (Provincia de Alagôas.) 1881. Revista do Instituto Archeologico e Geographico Alagoano. Junho de 1883, II, 177; mentions limestone in the Leopoldina district; granite. 
GAMA, DOMINICIO DA: Atlas Universal de geographia physica e politica. Nova ed. correcta. H. Garnier, Rio de Janeiro e Paris. (No date.) No. 32 is a geological map of Brazil.

GAMA, FILHO: $\nabla$. SALDANHA DA GAMA.

GAMA, Dr. J. DA: Riqueza mineral. O carbonado. Boletim da Secretaria de Agricultura, etc., do Estado da Bahia, II, No. 1, 39-44. Bahia, 1903.

GARDNER, GEORGE: Geological notes wade during a journey from the coast into the interior of the Province of Ceara, in the North of Brazil. embracing an account of a deposit of fossil fishes. Edinburgh New Philosophical Journal, $8^{\circ}$. XXX, 75-82. Edinburgh, 1841. Abstract: L'Institut. Paris, May 20. 1841.

GARDNER, GEORGE: On the geology and fossil fishes of North Brazil. Report British Assnciation Advancement Science for 1840. Transactions, 118-120. London, 1841. Abstract: L'Institut, 9e amée, no. 586, IX, 173-174. Paris, Mai 20, 1841.

GARDNER, GFORGE: Peixes petrificudos que se-achño na Provincia do Ceara. Jornal do Commercio, No. 95, 9 de Abril de 1842 ; published as an appendix to Boubée's Geologia Elementar, 54-55. Rio de Janeiro, 1846.

GARDNFR, GEORGF: On the existence of an immense deposit of chalk in the northern provinces of Brazil. Proceedings of the Plilosophical society of Glasgow, I, 146-153. Illustrated. Glasgow, 1844.

GARDNER, GFORGE: Contributions to a history of the relation between climate and vegetation in various parts of the globe. No. 1 . The regetation of Rio (de) Janeiro. Jour. Hort. Soc. of London, I, 191-198. IJondon, 1846.

GARDNFR, GFORGE: Travels in the interior of Brazil, principally through the northern provinces and the gold and diamond districts during the years 1836-1841. $8^{\circ}$, XVI + 562 pp., map. London, 1846 . Second ed., XVIII + 428 pp., map and plate. $8^{\circ}$. I London, 1849 . Many notes on the geology especially of the interior of Ceará, Piauhy, and Minas Geraes.

GARDNFR, GEORGE: Reisen in innern Braziliens, besonders durch die nördlichen Provinzen und die Gold- und Diamanten-districte. Aus dem Engl. von M. B. Lindau, 2 vols., 1 map. $8^{\circ}$. Dresden u. Leipzig, 1848. German translation of the title above.

GAUDICHAUD, C.: Voyage autour du monde, entrepris par ordre du Roi . . . executée sur les corvettes de S. M. l'Uranie et la Physicienne pendant les année 1817-1820, par $M$. Louis de Freycinet. 9 vols. Botanique par $M$. Charles Gaudichaud. $4^{\circ}$, vol. I, Géologie du Rio de Janeiro, 9-10. Paris, 1826.

GAUTIBR, FERDINAND: Ipanema et Taubaté. Revista Industrial de Minas Geraes. Anno 1, No. 8, 193-194. Ouro Preto, 15 Maio, 1894.

GEHLEN, A. F.: Platinum und Palladium in Brazilien und St. Domingos gefunden. Schweigger's Jourial für Chemie und Physik, I, 362. Nurewburg, 1811.

GEIKIE, JAMES: The evolution of climate. The Scottish Geographical Magazine, VI, 57-78, and map showing the geological and geographical development of Brazil. Edinburgh, 1890.

CEIKIE, JAMES: Address to the geographical section of the British Association for the Advancenient of Science, Edinburgh, 1892. The Scottish Geographical Magazine, VIII. Edinburgh, 1892. (Geology of east coast of Brazil, 471.)

GEINITZ, H. B.: Ueber einige Eruptivgesteine in đer Provinz São Paulo in Brasilien. Abh. Naturwis. G. Isis, Abtheilung 6, 31-34. Dresden, 1890.

GEINITZ, F. B.: Sur Stereosternum tumidum, Cope, du Musée Royal de Minéralogie de Dresde provenant de São Paulo (Brésil). Traduit sur le manuscrit allemand par J. Fraipont. Annales de la Société Géologique de Belgique, $4^{\circ}$, XXV bis, ler livraison, 35-42. Liége, 7 Sept., 1900. 
GENTH, F. A.: Contributions to mineralogy. Joseite and Tetradymite. Proceedings American Philosophical Society, XXIII, 31-34. Philadelphia, 1886. Abstract: Zeitschrift für Krystallographie und Mineralogie (Groth), XII, 487-488. Leipzig, 1887.

GERBER, H.: See BURTON, R. F.

GERBER, HENRIQUE: Geographical notes on the province of Minas Geraes. (Translated and communicated by Capt. R. F. Burton.) Jour. Royal Geog. Soc., XLIV, 262-300. London, 1874. Abstract: The Geol. Record for 1875,121 . London, 1877 .

GERBFR, HENRIQUE: Noções geographicas e administrativas da Provincia de Minas Geraes por Henrique Gerber, engenheiro da mesma Provincia. Re-impressão da 1a edição de 1863. Hannover, 1874. Geologia, 17-20; mineração, 31-34.

GERVAIS, FHNRI, et AMEGHINO, FLORENTINO: Les mammifères fossiles de l'Amérique du Sud. $8^{\circ}, \mathrm{XI}+225 \mathrm{pp}$. Paris and Buenos Aires, 1880.

GERVAIS, PAUL: Recherches sur les mammifères fossiles de l'Amérique Meridionale. [Mêmoire accompagné de dix planches lithogranhiêes. Extrait de la Zoologie de l'Expédition dans les parties centrales de l'Amer'ique du Sud publiée sous la direction de M. le Comte Francis de Castelnau.] Paris, 1855. $4^{\circ}, 63 \mathrm{pp}$. and plates. Some Brazilian tosail mammals.

GERVAIS, M. PAUI: Mêmoir sur plusieurs espéces de mammifères fossiles propres a l'Amérique Méridionale. Mémoires de la Société Géologique de France, 2e sér., IX. 5e, 1-44, et planches. $4^{\circ}$. Paris, 1873. Brazilian fossil mammals, $21,23,26$.

GERVAIS, P.: On the fossil mammalia of South America. Annals and Magazine of Natural History, 5th series, II, 271-272. London, 1878.

GFRVAIS, P.: (Sur une vertèbre fossile de la région de Bas-Amazone.) Comptes Rendus de l'Acad. Sci., LXXXIII, 29. Paris, 1876. Journal de Zoologie, V, 232-236, plate. Paris, 1876.

GERVAIS, PAUL: Crocodile gigantesque fossile au Brêsil. (Dinosuchus terror.) Journal de Zoologie, V, 232-236 + 1 planche. Paris (1876).

GERVAIS, P.: Tortue gigantesque fossile au Brésil. Journal de Zoologie, VI, 283-285 and plate. Paris, 1877. Abstract:Geological Record for 187\%, 287. London, 1880. ('This is Testudo elata, from the Pleistocene of the lower Amazonas, two thirds the size of the giant turtle of India, Collosochelys Atlas.)

GFRVAIS, P.: Nouvelles recherches sur les mammifères fossiles propres $\mathbf{a}$ l'Amérique Méridionale. Comptes Rendus de l'Acad. Sci., LXXXVI, 13591362. Paris, 1878. Abstract: The Geological Record for 1878, 297. Iondon, 1882.

GIBSON, A. M.: The mineral resources of Brazil. Engineering and Mining Journal, XLIX, 85-86. New York, 1890.

GIBSON, A. M.: Brazil's hidden wealth. Gems, gold, rubber and coffee. New York Times, Jan. 26, 1890.

GILL, A. C.: Petrographical notes on a rock collection from Fernando de Noronha. (A preliminary notice.) Johns Hopkins University Circulars, VII, No. 65, 71-72. Baltimore, April, 1888.

GIIMAN, C. F.: v. BRANNER, J. C., and GILMAN, C. F.

GINTY, W. G.: Report on the Candiota coal. (Part of the paper by Mr. Parkenham, 23-24, q. v.) London, 1867.

GINTY, W. G.: Report on the Candiota coal. (Letter addressed to Nathaniel Plant.) Appendix $H$ of "Brazil and the Brazilians." By Rev. James C. Fletcher and Rev. D. P. Kidder. 9th ed., 637. London, 1879.

GIRARD. H.: Der Diamant und seine Muttergestein in Brasilien. Neues Jahrbuch für Mineralogie, etc. Von Dr. K. C. von Leonhard und Dr. H. G. Bonn, Jahrgang, 1843, 307-310. Stuttgart, 1843. 
GLOCKER, [E. F.]: Ueber brasilianische Diamanten. Erdman's Journal für Praktische Chemie, XXXVIII, 318-320. Leipzig, 1846.

GOELDI, EMIL A.: See Derby, O. A. "Physical geography and geology of Brazil."

GöLDI, EMIL A.: Eine Naturforscher-Fahrt nach dem Litoral des südlichen Guyana zwischen Oyapock und Amazonenstrom. (October bis November, 1895.) Separatabdruck aus dem Jahresbericht der St. Gallischen Naturwissenschaftichen Gesellschaft, 1896-97. St. Gallen, 1896. (Geology, 37, 40,45 , chart.)

GOMES, ALFFONSO H. DE SOUZA: Relatorio sobre o melhoramento do porto do Natal, apresentado ao Ministro e Secretario dos Negocios da Agricultura. Natal, 1890. Pp. 10, map of the reef. Notes on the geology of the stone reef and harbor of Natal, Rio Grande do Norte.

GOMES, CARLOS THOMAZ DE MAGALHÃES: Analyse do lignito de Taquarassí. Revista Industriul de Minas Geraes. Anno 1, No. 1, 20. Ouro Preto, 15 de Outubro, 1893.

GOMES, CARLOS THOMAZ DE MAGALHÃES, e SILVA, AUGUSTO BARBOSA DA: As clivagens do quartzo. Revista Industrial de Minas Geraes. Anno IV, No. 22, 273-274. Ouro Preto, 30 de Marco, 1897. Annaes da Escola de Mlinas, no. 5, 19-24. Ouro Preto, 1902.

GOMES, CARLOS THOMAZ DE MAGALHĀES: (Analyses de 15 calcareos do Brazil.) Annaes da Escola de Minas, no. 5, 171-182. Ouro Preto, 1902.

GOMES, CARLOS THOMAZ DE MAGALHÃES: (Analyses de 20 amostras de manganez.) Annaes da Escola de Minas, no. 5, 185-192. Ouro Preto, 1902.

GOMES, CARLOS THOMAZ DE MAGALHĀES: (Diversos analyses de nineraes do Brazil.) Annaes da Escola de Minas, no. 5, 201-207. Ouro Preto, 1902.

GOMES, HENRIQUE CARLOS DE MAGALHÃOS: (Exploração geologica a oeste da Mantiqueira), 18-29 of Annexo A. do relatorio apresentado ao Dr. Secretario de Estado da Agricultura do Estado de Minas Geraes pelo Inspector de Terras e Colonização, Dr. Carlos Prates em 1897. Ouro Preto, 1897.

GOMES, JOSE COELHO: Empire of Brazil. Commercial and emigrational guide to Brazil. Compiled and translated from official publications by José Coelho Gomes, acting secretary of the Brazilian Legation. Washington, U. S. A. $8^{\circ}$. Washington, 1885. Mineral resources, 44-46.

GONÇALVES, ALPHEU DINIZ: O Hydrobucholzite (da Bahia). Boletim da Directoria da Agricultura, etc., do Estado da Bahia. VIII, 49-51. Bahia, 1906.

GONNARD, FERDINAND: Sur quelques cristaux de quartz du Brésil. Bulletin de la Société Francaise de Minéralogie, XXV, 56-59. Paris, 1902. Abstract: Zeitschrift für Krystallographie und Mineralogie (Groth), XXXIX, 184-185. Leipzig, 1904.

GONNARD, FERDINAND: Sur un cristal d'améthyste du Brêsil. Bulletin do la Société Frangaise de Mrinéralogie, XXV, 59-60. Paris, 1902. Abstract: Zeitschrift für Krystallographie und Mineralogie (Groth), XXXIX, 184185. Leipzig, 1904.

GONZAGA DE CAMPOS: $\nabla$. CAMPOS, L. F. GONZAGA DE.

GORCEIX, HENRI: Notice sur le gisement et l'exploitation de l'or a Lavras, province de Rio Grande du Sud. Bull. Soc. de l'Industrie Minérale. St. Etienne, 2me sér., IV, 361-381. Paris, 1875. Abstract: The Geological Record for 1875,121 . London, 1877.

GORCEIX: Résultats d'une première exploration de la province de Rio Grande du Sud (Brésil). Bull. Soc. Géol. de France, 3me sêrie, III, 55-56. Paris, 1875. Abstract: The Geological Record for 1875, 121. London, 1877.

GORCEIX, HENRIQUE: Conferencias feitas no Museu Nacional. $4^{\circ}, 31$ pl. Rio de Janeiro, 1876. 
GORCEIX, H.: Noticia sobre a jazida de cobre em Lavras e Caçapava na provincia de $\mathbf{S}$. Pedro do Rio Grande do Sul. $8^{\circ}, 8$ pages. Rio de Janeiro, 1876.

GORCEIX, H.: Sur la canga du Brésil et sur de bassin d'eau douce de Fonseca. Comptes Rendus de l'Acad. Sci. LXXXII, 631-632. Paris, 1876.

GORCEIX, H.: Les explorations de l'or dans la province de Minas Geraes, Brésil. Bull. Soc. Géogr., Gme série, XII, 530-543. Paris, 1876.

GORCEIX, H.: Sur une roche intercalée dans les gneiss de la Mantiqueire (Brésil). Comptes Rendus de l'Acad. Sci. LXXXII, 688-689, 1876. Also Bull. Soc. Géol. de France, 3me série, IV, 434-435. Paris, 1876.

GORCEIX, H.: Note sur la roche vulgairement au Brésil sous le nom de Canga, et sur le bassin d'eau douce de Fonseca (province de Minas Geraes). Bull. Soc. Géol. de France. 3me série, IV, 321-323. Paris, 1876.

GORCEIX: Sur divers mineraux du Brésil. (Extrait d'une lettre.) Bull. Soc. Géol. de France, 3me série, IV, 522. Paris, 1876.

GORCEIX, H.: Mina de carvão de pedra em Minas Geraes. Officio dirigido ao Presidente da Provincia. Auxiliador da Industria Nacional, No. 7, XIVI, 164-165. Rio de Janeiro, Julho, 1878.

GORCEIX, H.: Estudos geologicos e mineralogicos sobre algumas localidades da Provincia de Minas Geraes pelos alummos engenheiros da Escola de Minas de Ouro Preto. Archivos do Museu Nacional do Rio de Janeiro, III, 9-10. Rio de Janeiro, 1878.

GORCEIX, HENRIQUE: Noticia sobre a jaziđa e exploração do ouro em Lavras e em Caçapava, Provincia de S. Pedro do Rio Grande do Sul. (Traduzida do Francez.) $8^{\circ}, 23$ pages. Rio de Janeiro, 1874. Tambem no Auxiliador da Industria Nacional. No. 5, Maio de 1878, XLVI, 109 114 ; No. 6, Junho de 1878, 133-137. Rio de Janeiro, 1878.

GORCEIX, H.: (Gisements de topaze au Brésil.) Revue de Géologie pour les années 1876 et 1877, 199-200. Paris, 1879 .

GORCEIX: Sur le gisement du diamant au Brêsil. (Extrait d'une lettre a M. Delesse.) Bull. Soc. Minéral. de France, III, 36-38. Paris, 1880. Abstract: Zcitschrift für Krystallographie und Mineralogie (Groth), IV, 407. Leipzig, 1881.

GORCEIX, HENRIQUE: O ferro e os mestres de forja na Provincia de Minas Geraes. $8^{\circ}, 16$ pages. Ouro Preto, 1880. Idem, $4^{\circ}, 24 \mathrm{pp}$. Rio de Janeiro, 1880.

GORCFIX: Sur les schistes cristallins du Brésil et les terres rouges qui les recouvrent. Extrait de lettres à M. 'Delesse. Comptes Rendus de ${ }^{\prime}$ Acad. Sci., XCI, 1099-1101. Paris, 1880.

GORCEIX, H.: Sur la martite du Brésil. (Extrait d'une lettre à M. Delesse.) Comptes Rendus de l'Academie des Sciences, XC, 316-318. Paris, 1880. Abstract: Neues Jahrbuch für Mineral, 1881, I, 13, Referate. Abstract: Zeitschrift fúr Krystallographie und Mineralogie (Groth), IV, 408. Leipzig, 1881.

GORCEIX, HENRIQUE: The iron industry of Minas Geraes. The Rio News, VII, No. 24, Aug. 24, 1880; VII, No. 25, Sept. 5, 1880. Rio de Janeiro, 1880. Froin Revista Brazileira, Rio de Janeiro.

GORCFIX, HENRIQUE: Geology of the 'rovince of Minas Geraes. Abstract of two articles in the Annaes da bscola de Minas de ouro Preto. The Rio News, VIII, No. 15, Rio de Janeiro, May 24, 1881. Abstract: Amer: Jour. Sci, CXXII, 221-225. New Haven, 1881.

GORCEIX, H.: Estudo chimico e geologico das rochas do centro da Provincia de Minas Geraes. Annaes da Escola de Minas de Ouro Preto, No. 1, 1-12. Ouro Preto, 1881.

GORCEIX, H.: Estudo geologico das jazidas de topazios da provincia de Minas Geraes. Annaes da Escola de Minas de Ouro Preto, No. 1, 13-34. Ouro Preto, 1881. 
GORCEIX: Sur les gisements diamantifères de Minas Geraes, Brésil. Comptes Rendus de l'Acad. des Sci., XCIII, 981-983. Paris, 1881. Bull. Soo. Minéral. de France, V, 9-13. Paris, 1882. Abstract: Nenes Jahrbuch für Mineralogie, 1883 , I, 378-379, Referate.

GORCEIX, H.: Etude géologique des gisenents de topazes de la province de Minas Geraes, Brésil. Annales Scientifiques de l'École Normal supérieure, 2e sér., XI, 1-32, 2 mans. $4^{\circ}$. Paris, 1882.

GORCEIX, H.: Brazilian diamonds and their origin. Popular Science Monthly, XXI, 610-620. New York, 1882.

GOROEIX, H.: Note, sur un mica vert des quartzites d'Ouro Preto, Brésil. Bull. Soc. Minéral., V, 308-310. I'aris, 1882. Abstract: Neues Jahrbuch für Mineralogie, 1884, 1, 20, Referate. Abstract: Zeitschrift für Krystallographie und Mineralogie (Groth), IX, 593. Leipzig, 1884.

GORCEIX, H.: Diamants et pierres précieuses du Brésil. La Revue Scientifique, 3me sêrie, III, 2e année, 1er, sér., Janvier à Juillet, 1882, 553-561. Paris, 1882.

GORCEIX: Sur les gites diamantifères du centre de la province de Minas Geraes (Brêsil). Bull. Soc. Géol. de France, 3me série, X, 134-135. Paris, 1882. Abstract: Transactions of the North of England Institute of Mining and Mechanical Engineers, XXIII, 29. Newcastle-upon-Tyne, $188 \pm$.

GORCEIX, H.: Hstudo chimico e mineralogico das rochas dos arredores de Ouro Preto. Annaes da Éscola de Minas de Ouro Preto, 1883, N. 2, 7-23. Revista de Engenharia, 14 de Nov. de 1883, V, 297-298; 28 de Nov. de 1883, V, 314-316; 14 de Dez. de 1883, V, 325-328. Rio de Janeiro, 1883.

GORCEIX, H., et JANNETTAZ, ED.: Note sur quelques mineraux des roches metamorphiques des environs d'Ouro Preto. (Miuas Geraes, Brésil), avec observations par Ed. Jannettaz. Bull. Soc. Minéral. de France, VI, 27-34. Paris, 1883. Abstract: Newes Jahrbuch für Mineralogie, 1884, II, 302-303, Referate. Abstract: Zeitschrift für Krystallographie und Mineralogie (Groth), X, 620-621. Leipzig, 1885.

GORCEIX, H.: Note sur un oxyde de titane hydraté, avec acide phosphorique et diverses terres, provenant des graviers diamantifères de Diamantina, Minas Geraes, Brésil. Bull. Soc. Minéral. de France, VII, 179-182. Paris, 1884. Abstract: Zeitschrift für Krystallographie und Mineralogic (Groth), XI, 638. Leipzig, 1886.

GORCEIX, H.: Lund e suas obras no Brazil (segundo o professor Reinhardt). Annaes da Escola de Minas de Ouro Preto, No. 3, pp. 7-58. Rio de Janeiro, 1884.

GORCEIX, H.: Géologie (du Brésil). La Grande Encyclopédie, VII, 1081. $4^{\circ}$. Paris, n. d.

GORCEIX, H.: Bacias tertiarias d'agua doce nos arredores de Ouro Preto (Gandarela e Fonseca), Minas Geraes, Brazil. Annaes da Escola de Minas de Ouro Preto, No. 3, 95-114. Rio de Janeiro, 1884.

GORCEIX: Noticia sobre os cascalhos diamantiferos. Annaes da Escola de Minas do Ouro Preto, No. 3, 195-207. Contendo os dois artigos seguintes: Noticia relativa a alguns mineraes dos cascalhos diamantiferos contendo acido phosphorico, alumina e outras terras do familia do cerium, 197-202. Noticia relativa a um zeolitho de uma rocha pyroxenica da bacia do Abaetê, Minas Geraes, 205-207. Rio de Janeiro, 1884. Abstract: Transactions of the North of England Institute of Mining and Mechanical Engineers, XXXIV, 38. Newcastle-upon-Tyne, 1885.

GORCEIX, H.: Note sur une zéolite d'une roche pyroxenique du bassin de l'Abaété, Minas Geraes, Brésil. Bull. Soc. Minéral. de France, VII, 32-35. Paris, 1884. Annacs da Escola de Minas de Ouro Preto, n. 3, 1884, 205210. Abstract: Nenes Jahrbuch für Minéralogie, 1886, I, 188-189, Referate. Abstract: Zeitschrift für Krystallographie und Mineralogie (Groth), XI, 203. Leipzig, 1886. 
GORCEIX, H.: Sur les minéraux qui accompagnent le diamant dans le nouveau gisement de Salobro, province de Bahia, Brésil. Comptes Rendus de l'Acad. Soi., XCVIII, 1446-1448. Paris, 1884. Abstract: Zeitschrift für Krystallographie und Mineralogie (Groth), XI, 639. Leipzig, 1886.

GOROEIX: Nouveau mémoire sur le gisement du diamant à Grão Mogor, province de Minas Geraes, Brésil. Comptes Rendus de l'Acad. Sci., XCVIII, 1010-1011. Paris, 1884.

GORCEIX: Gisement de diamants de Grão Mogor, province de Minas Geraes, Brésil. Bull. Soc. Géol. de France, 3me sêrie, XII, 538-545. Paris, 1884. Abstract: Transactions of the North of England Institute of Mining and Mechanical Engineers, XXXIV, 45. Newcastle-upon-Tyne, 1885.

GORCEIX, H.: Etude des minereaux qui accompagnent le diamant dans le gisement de Salobro, province de Bahia (Brésil). Bull. Soc. Minéral. de France, VII, 209-218. Paris, 1884. Fstudo dos mineraes que acompanhão o diamante na jazida de Salobro provincia da Bahia, Brazil. Annaes da Escola de Minas de Ouro Preto, n. 3, 219-227. Rio de Janeiro, 1884 . Abstract: Transactions of the North of England Institute of Mining and Mechanical Engineers, XXXIV, 38. Neweastle-upon-Tyne, 1885.

GORCEIX, H.: Analyses feitas no laboratorio de docimasia da Escola de Minas de Ouro Preto, II. Ouro do Tapnia, Bahia, 201, V (Com Leonidas Damazio). Amostras de phosphatos, 208-207. Annaes da Escola de Minas de Ouro Preto, 1885, No. 4, 201-208.

GORCEIX: Sur la flexibilitế des roches du Brésil connues sous le nom d'itacolumites. Bull. Soc. Géol. de France, 3me sêrie, XIII, 272. Paris, 1885.

GORCEIX, H.: Sur des sables à monazites de Caravellas, province de Bahia Brésil. Comptes Rendus de l'Acad. Sci., C, 356-358. Paris, 1885. Also Bull. Soc. Minéral. de France, VIII, 32-35. Paris, 1885.

GORCEIX, H.: Estudo sobre a monazita e a xenotima do Brazil. Annaes da Escola de Minas de Ouro Preto, N. 4, 29-48. Ouro Preto, 1885. Abstract: Bull. Soc. Frangaise Minéral., X, 160-161. Paris, 1887. Abstract: Monthly Bulletin of American Republics, VI, 596. Washington, 1898.

GORCEIX, H.: Sur le xenotime de Minas Geraes (Brésil). Conıtes Rendus de l'Acad. Sci., CII, 1024-1026. Paris, 1886. Abstract: Neues Jahrbuch für Minéral., 1888, I, 8-9. Referate.

GOROEIX, H.: Sur le gisement de diamants de Cocaës, province de Minas Geraes, Bresil. Conptes Rendus de l'Acad. Sci., CV, 1139-1141. Paris, 1887. Abstract: Neues Jahrb. f. Minerat., 1889, I, 119-120, Referate.

GORCEIX, HENRI: Mineralogie (du Brésil), Chap. IV, 61-104 of le Brésil en 1889. Paris, 1889. See F. J. de Santa Anna Nery.

GORCEIX, HENRI: La géologie (du Brésil). See "Le Brêsil by E. Levasseur, extrait de La Grande Encyclopédie, Chapitre IV, 7-8. 2e edition. Paris, 1889. See Levassevr.

GORCEIX, HENRI: Le Brésil en 1889 avec une carte de l'Empire en chromolithographie, des tableaux statistiques, des graphiques et des cartes. Ouvrage publié par les soins dusyndicat dư comité franco-brésilien pour l'exposition universelle de Paris. Avec la collaboration de nombreux ecrivains du Brésil sous la direction de M. F. J. de Santa Anna Nery. (Mineralogie, par Gorceix.) In $8^{\circ}, \mathrm{X} I X, 699$ pages. For the part relating to coal in Brazil, abstract in The Iron and Coal Trades Review, XLII, 296. London, March 13, 1891. Also Journal of the Iron and Steel Instituute, I, 299. London, 1891.

GORCEIX, H.: L'état de São Paulo, Brésil. Comptes Rendus Soc. Géogr., 1890, 499-505. Paris, 1890.

GORCEIX, H.: (Exploraç̃es geographicas no Brazil.) Revista de Engenharia, No. 251, XIII, 360-362. Rio de Janeiro, 14 de Fevereiro de 1890.

GORCEIX, H.: tude de gisements de diamants dans l'ftat de Minas-Geraes (Bresil). Compte Rendu de l'Association Francaise pour l'Avancement des Sciences, 19me session, 1er partie, 186. Paris, 1890. 
GORCEIX, H.: (Letter regarding the explorations in Brazil, especially those of-Derby, addressed to the Societé Géographique.) Compte Rendu des Séances de la société de Géographie, 1890, 499-506. Paris, 1890.

GORCEIX, HENRI: Minas Geraes, l'un des tats-Unis du Brêsil; situation, resources, population. $30 \mathrm{pp} .8^{\circ}$. Paris, 1891.

GRAÇA, JOĀo CORDEIRO DA: Relatoria dos estudos mineralogicos e geologicos da Provincia de $\mathbf{S}$. Pedro do Rio Grande do Sul apresentado ao Governo Imperial. $8^{\circ}$, 101 pp. Rio de Janeiro, 1883.

GRAÇA, JOÃO CORDEIRO DA: Breve noticia historica do desenvolvimento da siderurgia e'estatistica de algumas fabricas da Europa; seu progresso nos Estados Unidos colligida e traduzida pelo Engenbeiro João Cordeiro da Graça. Publicada por ordem do Exm. Sr. Conselheiro Henrique d'Avila, Ministro e Secretario d'Estado dos Negocios da Agricultura, Commercio e Obras Publicas. Rio de Janeiro, 1883. 87-93, account of a visit to the Fabrica de Ferro de S. João de Ypanema.

GRAEFF, F. FR.: Mineralogisch-petrographische Untersuchung von Eläolithsyeniten von der Serra de Tinguá, Provinz Rio de Janeiro, Brasilien. Neues Jahrbuch für Mineralogie, II, 222-262. Stuttgart, 1887. Separate, Stuttgart, 1887. Abstract in Mineralogical Mag. and Jour. Mineral. Boc., VII, No. 35, 231-237. London, 1887. Abstract: Zeitschrift für Krystallographie und Mineralogie (Groth), XV, 637-638. Leipzig, 1889.

GRAEFF, FRANZ FR.: Laavenit in brasilianischen Elaeolithsyenit. Neues Jahrbuch für Mineralogie, 1887, I, 201-203. Briefliche Mittheilungen. Abstract: Bull. Boc. Francaise de Minéralogie, XI, 251. Paris, 1888. Abstract: Zeitschrift für Krystallographies und Mineralogie (Groth), XIV, 498 . Leipsig, 1888.

GRAFAM, MARIA: Journal of a voyage to Brazil. By Maria Graham. London, 1824. (Note on fossil bones in the State of Pernambuco eight leagues northeast of Penedo and near Recife, 130.)

GRANDIDIER, ALFRED: Les cartes et les appareils de géographie et de cosmographie, les cártes géologiques et les ouvrages de metéoroligie et de statistique. Rapports du Jury International, Groupe II, Classe 16, Exposition Universelle Internationale de 1878 a Paris. $8^{\circ}$. Paris, 1882. Cartes géologiques du Brésil, 482-483.

GRASHOF, E. E. F.: Landschaftsbilder an der Bay von Rio de Janeiro. Globus, X, 235. Braunschweig, 1866.

GRATEAU, ED.: Découverte de la houille au Brêsil. Annales au Génie Civil. (Annee, 1864.) $8^{\circ}$, III, 510. Paris, Eugène Lacroix, Editeur, 1865.

GRAVATA, A.: Mineral resources of Bahia. Quoted from the Diario da Bahia, in Monthly Bulletin of the International Bureau of American Republics, XVI, 355-357. Washington, 1904.

GRAVATA, A.: Memoria sobre as minas da Bahia. Boletim da Secretaria de Agricultura do Estado da Buhia. III, 157-166. Bahia, 1904.

GREVEN, FR.: Manganerze in Brasilien. Stahl und Eisen, 1899, 19, 439. Chemisches Repertorium (Supplement zur Chemiker Zeitung, No. 42), XXIII, 160. Cöthen, 27 Mai, 1899. Abstract: Jour. Iron and Steel Inst., LVI, 322-323. London, 1899.

GRODDECK, Dr. VON: Ueber das Vorkommen von Gold- Kupfer- und Bleierzen in der Provinz Rio Grande do Sul in Brasilien. Berg- und Hïtten. Zeitg., 7 December, 1877. No. 49, 422-424. Abstract: Neues Jahrbuch für Mineral., 1878, 419. Abstract: Zeitschrift für Krystallographie und Mineralogie (Groth), III, 324-325. Leipzig, 1879.

GROSSI, V.: Climatologia, geologia e idrologia medica dello Stato Brasiliano di Minas Geraes. Torino, 1893.

GROSSI, V.: Le miniere del Brasile, Roma, 1895. Abstract: Scottish Geographical Magazine, XII, 471-472. Edinburgh, 1896.

GROSSI, DE VINCENZO: Nel paese delle Amazzoni. $12^{\circ}, 130$ pp. Roma, 1897. Geografia fisica, 9-32. 
GROSSI, V.: Appunti sulla geografia fisica del Brasile. Revista Italo-Americana, I. Roma, 1902.

GROTH, P.: Ueber farblosen Cordierit aus Brasilien. Zeitschr. f. Krystallogr., VII, 594. Abstract: Neues Jahrbuch für Mineral., 1883. II, 173, Referate.

GRUNHUT, LEO: Beiträge zur krystallographischen Kenntniss des Andalusites und des Topases. Andalusit aus Brasilien, 120-124. Topas von Brasilien; 151-157. Zeitschrift für Krystallographie und Mineralogie, IX, 1884, 120-124; 151-157. Leipzig, 1884. Abstract: N. Jahrb. f. Mineral., 1886, II, 197-202. (Topas von Brasilien, 202.)

GRZYBOWSKI, JOSEF: Die Tertiärablagerungen des nördlichen Peru und ihre Molluskenfauna. Neues Jahrbuch für Mineral., Beilage Band, XII, 610-661. Stuttgart, 1899.

GUERNSEY, A. H.: The Andes and the Amazon. (Chiefly abstracts from James Orton's book of this name.) Harper's Magazine, 1870, $\mathrm{XL}, 344-358$. New York, 1870. Few geologic notes.

GUIGNET, E., and TELIES, A: Composition chimique des eaux de la baie de Rio de Janeiro. Comptes Rendus de l'Acad. Sci., LXXXIII, 919-921. Paris, 1876.

GUIGNET, E., and ALMEIDA, G. OZORIo DE: Sur un fer mêtếorique très riche en nickel, trouvé dans la province de Santa Catharina, Brésil. Comptes Rendus de l'Acad. Sci., LXXXIII, 917-919. Paris, 1876.

GUIGNET: Sur le fer nickelé de Sainte-Catherine au Brésil. (Lettre a $M$. Daubrée.) Avec observations par Daubrée. Comptes Rendus de l'Acad. Sci., LXXXIV, 1507-1509. Paris, 1877.

GUIGNET, E.: Sur divers échantillons d'argile et de houille du Brêsil. Comptes Rendus de l'Acad. Sci., LXXXIV, 1326-1328. Paris, 1887. Abstract: The Geological Record for 1877. 200. London, 1880.

GUIMARÃes, ARTHUR: v. PRATES, CARLOS.

GULLANA, J. K.: Brazilian carbons. Jour. Soc. Arts, LI, 22. London, 1902.

GUMBEL, C. W.: Lithologisch-mineralogische Mittheilungen. Von dr. C. W. Gümbel. I, Gesteine der Kerguelen-Insel. (II Das weisse mineral der pflanzenversteinerungen aus $\mathrm{d}$. Tarentaise.) Tschermak's Mineralogische u. Petrographische Mittheilungen. Neue Folge. Wien, $1880,8^{\circ}$ II, 186191. Analysis of phonolite from Fernando de Noronha, 188-189.

GUNTHER, GUSTAV JUIIUS: Mineral deposits of northeastern Brazil. The Mining Journal, XXXVII, 130. London, March 2, 1867.

GUTHRE, F. B.: v. DAVID.

GUTSMUTHs, J. G. F.: Ueber das Entstehen der Schlammbänke von den Küstenlande Guyana. Hertha, IX, 381-393. Stuttgart, 1827. Abstract: Bull. des sci. Nat. et de Géol., XIII, 309-310. Paris, 1828.

HAACK, HERMANN: Die mittlere Höhe von Südamerika. Inaugural-Dissertation verfasst und der hohen philosophischen Fakultät der vereinigten Friedrichs-Universität Halle-Wittenberg zur Erlangung der philosophischen Doktorwürde vorgelegt von Hermann Haack aus Gotha. Halle, A. S. $8^{\circ}$, 88 pp. 1896. Brasilien, 32-34.

HAHN, FRIEDRICH GUSTAV: Untersuchungen über das Aufsteigen und Sinken der Küsten . . . Ein Beitrag zur allgemeinen Erdkunde. Habilitationsschrift durch welche mit Zustimmung der Philosophischen Facultät der Universität Leipzig zu seiner Sonnabend den 3 Mar., etc. Leipzig, 1879. Die Ost- und Nordküste Südamerikas, 93-98.

FAIDINGER, WILFFLM: Veränderungen in eisen-hattigen Mineralien. Poggendorff's Annalen der Physik. und Chemie, XI, 188-191. Leipzig, 1827.

HAIDINGER, W.: Ueber. den durchsichtigen Andalusit von Minas Novas in Brasilien. Abhandlungen der $k$. böhm. Gesellschaft der Wissenschaften, V. Folge, Band. 3, 263-270. Prag, 1844. Separate. Prag, 1844. 
HAIDINGER, W.: Vorworte zu "Ueber das Geognostische Vorkommen der Diamanten und ihre Gewinnungsmethoden auf der Serra do Grão-Mogor in der Provinz Minas Geraes in Brasilien, von Virgil von Helmreichen." Wien, 1846.

HAIDINGER, W.: Vorworte zu "Die geologische Uebersichtskarte des mittleren Theiles von Sud-Amerika" von Franz Foetterle. Wien, 1854.

HAIFIELD, H. G. F.: Atlas e relatorio concernente á exploração do Rio de São Francisco desde a Cachoeira da Pirapóra até o Oceano Atlantico. Levantado por ordem do governo de S. M. Dom Pedro II, 1852-1854. Ill. 57 pp. folio, 36 maps. Rio de Janeiro, 1860. Notice: Petermann's Mittheilungen, 1866, 412-414.

HALL, BASIL: V. JAMESON.

HAMLIN, AUGUSTUS C.: Leisure hours among the gems. $8^{\circ}$. Boston, 1884. Brazilian diamonds, $37-46 ; 221-223$.

HANSEN, SöREN: La race de Lagôa Santa. L'homme fossiłe de Pontimelo. E M useo Lundii. I, paper 5, 35-37, 5 planches. 1888 . Abstract of the next paper.

HANSEN, SöREN: Lagôa Santa Racen. E Museo Lundii, I, paper 5, 1-34. III. Kjöbenhavn, 1888.

HANSEN, SöREN: On a fossil skull from Lagôa Santa, Brazil. Journal of the Anthropological Institute of Great Britain and Ireland, XVII, 43. London, 1888.

HARLAN, R.: Medical and physical researches or original memoirs, etc. XXXIV-XXXV. Philadelphia, 1835. Refers to evidence of elevation two degrees west of Rio de Janeiro; human bones in tufa and shells.

HARRIS, G. D.: The Midway stage. Bulletins of American Paleontology, I, No. 4. Correlations made with Brazil, 40-43. Ithaca, N. Y., June, 1896.

HARRIS, G. D.: Geology of the Mississippi embayment. A report on the geology of Louisiana (for $1900,1901,1902$.) Baton Rouge, 1902. Comparison of the Eocene of Louisiana with that of Brazil, 10-11.

HARTING, P.: Description d'un diamant remarquable contenant des cristaux. Verhandlingen der Koninklijke Akademie van Wetenschappen (2 esde deel), VI, 15 pp. $4^{\circ}$, plate. Amsterdam, 1858.

HARTT, C. FRED.: A vacation trip to Brazil. American Naturalist, Feb., 1868, I, 642-651. Salem, 1868.

HARTT, C. FRED.: Resume of a lecture on the "Growth of the South American Continent," delivered before the Library Association, Ithaca, N. Y., Dec. 4, 1868. Cornell Era, Dec. 12, 1868. Also separate. Ithaca, 1868.

HARTT, C. F.: (Account of a lecture on the glaciation of Brazil.) Amer. Naturalist, I, 623-624. Salem, Jan., 1868.

HARTT, CH. FRED.: The cruise of the "Abrolhos." American Naturalist, II, 85-93. Salem, April, 1869.

HARTT, CH. FRED.: A naturalist in Brazil. American Naturalist, II, 1-13. Ill. Salem, March, 1869.

HARTT, C. F.: The gold mines of Brazil. The Mining Journul, XXXIX, 849. London, Nov. 13, 1869. (Quoted from the Engineering and Mining Journal of New York.)

HARTT, C. FRED.: Remarks on the Brazilian coral fauna. Trans. Conn. Acad. Arts and Sciences, I, part 2, 364-365. New Haven, 1867 to 1871.

HARTT, C. FRED.: (Letter from Rio Amazonas to Prof. J. S. Newberry upon the discovery of the Itaitúba limestones.) Proc. Lyceum of Nat. Hist. in the city of New York, I, 89-91. New York, 1870. [Date of publication not given; title page wanting. The letter of Hartt is dated Oct. 4, 1870.]

HARTT, CH. FRED.: A geologia do Para. Reprint of a report written for the editor of the Diario do Grão Pará in 1870, at Pará, Brazil. Published in the Boletim do Museu Paraense, I, No. 3, June, 1896, 257-273, with footnote by Dr. E. A. Goeldi. Pará, 1896. Abstract: Petermann's Mittheilungen, page 189. Gotha, 1896. 
HARTT, CH. FRED.: Geology and physical geography of Brazil. Maps and illustrations, pp. xxili +620 . Boston, 1870. Review: $O$ Novo Mundo. Ill. New York, Outubro 24, 1870. Review: Amer. Naturalist, March, 1871, V, 33-36. Annual of Scientific Discovery for 1871, 246-248. Boston, 1871. Review: Old and New, III, 91-93. Boston, 1871. Review by A. R. Wallace, Nature, II, 510-512. London, 1870. Notice: Petermann's Mittheilungen, XVII, 240, Gotha, 1871. Hxtracts: Revue de Géologie pour les années 1869 et 1870 par M. Delesse et M. De Lapparent, 91-92. Paris, 1873. Review and abstracts : Revıle de Géologie pour les années, 1871-1872, XI, 175-178. Paris, 1875.

HARTT, CH. FRED.: On the geology of Brazil. Jour. Amer. Geographical and Statistical Society, II, pt. 2, 55-70. New York, 1870.

HARTT, CH. FRED.: Geological discoveries in Brazil. (Fxtract from letter.) American Naturalist, V, 342-343. Salem, 1870.

FARTT, C. F.: Resume of Hartt's views of Brazilian drift, diamonds, etc. Annual of Scientific Discovery for 1871, 246-28. Boston, 1871.

AARTT, CH. FRED.: Brazilian rock inscriptions. American Naturalist, $\mathbf{V}$, 139-147. Ill. Salem, 1871 .

HARTT, CH. FRED.: Amazonian drift. American Journal of Science, third series, I (CI) , 294-296. New Haven, 1871.

HARTT, CHAS. FRED.: A proposed fourth expedition to Brazil. (For private distribution.) 4 pp. $8^{\circ}$. Ithaca (N. Y.), June 16, 1871.

HARTT, CH. FR.: The ancient Indian pottery of Marajô, Brazil. (Illustrated.) American Naturalist, July, 1871, V, 259-271. Abstract under title of Reliquias de Indios na Ilha do Marajó, in Novo Mundo, Agosto 24, 1871 , I, p. 171 (with 10 cuts). New York, 1871.

HARTT, CH. FRED.: Discovery of Lower Carboniferous fossils on the Rio Tapajos. American Naturalist, IV, 694-695. Salem, 1871.

HARTT, CH. F.: On the Tertiary basin of the Marañon. American Journal of Science, IV, 53-58. New Haven, 1872.

FARTT, CH. FRED.: Theory of the glacial origin of the Amazonas basin. Proceedings Boston Society Natural History, XV, 152-154. Boston, 1872.

HARTT, CHAR. FRED.: Recent explorations in the Valley of the Amazonas, with map. Transactions of the American Geographical Society of New York, III, 231-252. Albany, 1872.

HARTT, CHARLES FRED.: On the occurrence of face urus in Brazil. American Naturalist, VI, 607-610. Salem, 1872.

HARTT, CH. FRED, and DERBY, O. A.: Abstract of Hart's reconnaissance of the Lower Tapajos and Derby's report on the Carboniferous Brachiopoda of Itaitúba on the Rio Tapajos, Province of Pará. Published in Bull. of the Cornell Univ. (Science), 1874, I, Nos. 1 and 2 . American Journal Science, VIII (CVIII), 144. New Haven, 1874.

FARTT, CH. FRED.: Contributions to the geology and physical geography of the Lower Amazonas. Bulletin of the Buffalo Society of Natural Science, I, 201-235. Buffalo, 1874. Abstract: Amer. Jour. Sci., CVII, 607. New Haven, 1874. Abstract: O Novo Mundo, Abril 23, 1874, IV, 128. New York, 1874. Review: Pop. Sci. Monthly, V, 758. New York, 1874. Review, with illustration, American Naturalist, Oct., 1874, VIII, 673-679. Review: Petermann's Mittheilungen, XX, 440, Gotha, 1874.

HARTT, CH. FRED.: Report of a reconnaissance of the Lower Tapajos. Bulletin of the Cornell University (Science), I, Nos. 1 and 2, 11-37. Ill. Ithaca, N. Y., 1874. Abstract: Neues Jahrb. f. Min., 1877, 663-664.

HARTT, CH. FRED.: Preliminary report of the Morgan Expeditions, 1870-71. Bulletin of the Cornell University (Science), I, Nos. 1 and 2, 1-10. Ithaca, N. Y:, 1874.

HARTT, CHAR. FRED.: Algumas considerações sobre o recife de Pernambuco. Revista do Instituto Polytechnico, V, Rio de Janeiro, Dec., 1875. (Dated Março, 1876, 2d part, 21-26.) 
HARTT, CHAR. FRED.: Relatorio preliminar dos trabalhos da Commissão Geologica na provincia de Pernambuco. $8^{\circ}, 11$ pp. Rio de Janeiro, 1875. Also in Diccionario Geographico das Minas do Brazil. Por F. 1. Ferreira. 131-137. Rio de Janeiro, 1885.

HARTT, CH. FRED.: Devonian rocks in the Amazonian valley. American Naturalist, $\mathrm{V}, 121-122$. Salem, 1871.

HARTT, CH. FRED., and RATHBUN, R.: Morgan Expeditions, 1870-71. On the Devonian trilobites and mollusks of Ererê, province of Pară, Brazil. Ann. Lyceum Nat. Hist. of N. Y., XI, 110-127. New York, May, 1876. Brief mention Amer. Jour. Sci., CX, 154. New Haven, 1875. Abstract: Neues Jahrbuch f. Mineral., 1877, 107.

HARTT, CH. FRED.: The Geological Survey of Brazil. First preliminary report made to the councellor Th. José Coelho de Almeida, Minister and Secretary of State for Agriculture. (Translated and abridged from the Portuguese by Theo. B. Comstock.) American Journal of Science, CX1, 466-473. New Haven, 1876.

HARTT, CH. FRED.: Exploracões scientificas. I. Commissão Geologica do Brazil. Catalogo da Exposição de Obras Publicas do Ministerio da Agricultura, 95-106. Rio de Janeiro, 1876.

HARTT, C. F.: Conferencia sobre o recife de Pernambuco, o Rio S. Francisco, a cachoeira de Paulo Affonso, etc. O Globo. Rio de Janeiro, 14 de Jan., 1876.

HARTT, CARLOS FREDERICo: Inscripções em rochedos do Brazil. Traducção de João Baptista Regueira Costa. Publicação do Instituto Archelogico e Geographico Pernambucano. $12 \mathrm{pp} .8^{\circ}$, plates. Pernambuco, 1895.

HARTT, CH. FR.: Trabalhos restantes ineditos da Commissão Geologica do Brazil (1875-1878). Introducção, 155-163; II, A regiño de Breves, 173181; III, O Rio Tocantins, 181-191 ; Boletim do Museu Paraense, II, No. 2, Pará, 1897; V, Monte Alegré e Ereré, 322-340 ; VIII, A Serra de Paranaquàra, 352-358; Boletim do Museu Paraense, II, No. 3, Pará, 1898. Abstract: Petermann's Mittheilungen, 1898, 208.

HARTT, CH. FR.: Notas biographicas sobre os trabalhos de. Ch. Fr. Hartt. Almanack Popular Brazileiro de 1903. Tambem no Diario Popular, Pelotas, Rio Grande do Sul, no. 156, 8 de Julho de 1903.

HAUSMANN, J. FR. I., und F. WöHLER: Ueber den Anthosiderit, eine neue Mineral-Species aus Brasilien. Göttingische gelehrte Anzeigen unter der Aussicht der Kgl. Gesellschaft der Wissenschaften, I, 29 stück, 281286. Göttlingen, 1841. Also Erdmann's Journal für Prakt. Chemie, XXII, 412-415. Leipzig, 1841.

HAUSMANN, J. FR. L.: Tellur-Wismuth aus Brasilien, Neues Jahrb. für Mineralogie, Geognosie, Geologie und Petrefakten-Kunde. Stuttgart, 1852, 698-701.

HAUY: Mémoire sur des topazes du Brésil. Annales du Muséum National d'Histoire Naturelle, I, 346-352. Paris, an. XI, 1802.

HAWKSHAW, Sir JOHN: Melhoramento dos portos do Brazil. Relatorio de.. . Publicação official, 115 pp., $4^{\circ}$. Rio de Janeiro, 1875. In Portuguese and English, maps and geologic observations on the ports. An English edition of this work seems to have been published under the title of "Brazilian Harbours." Sir John Hawkshaw's reports are dated 15th July, 1875, folio. No date or place of publication given.

HAWKSHAW, J. CLARKE: Notes on the consolidated beach at Pernambuco. Quarterly Journal of the Geological Society of London, XXXV, 239-214. London, 1879.

HAY, G. U.: The scientific works of Prof. Chas. Fred. Hartt. Trans. Royal Society of Canada, 2d series, 1899-1900, V, Sec. IV, 155-165. Separate. Montreal, 1899. 
HEBERT, E.: Rapport sur la partie gêologique et minêralogique du voyage de M. M. Grandidier frères (Emest et Alfred) dans l'Amérique méridionale lu a la section des Sciences du comité des travaux historiques et des Societés savantes. $8^{\circ}, 5$ pages, Paul Dupont (s. d.). Paris, 21 Mai, 1860. Extract: Revue des Socs. Savantes, Sept., 1860.

FFHL, R. A.: Das brasiliansche Kïistenland zwischen dem $21^{\circ}$ und $23^{\circ}$. Südlicher Breite. (Eine geographisch-geolische Skizze.) Petermann's Mittheilungen, XXVIII, 443-447. Gotha, 1882.

HEINTZ, W.: Ueber den färbenden Bestandtheil des Feuersteins, Cameos und Amethystes. Poggendorff's Annalen, LX. 519-527. Leipzig, 1843. Abstract: Jahres-Bericht über die Fortschritte der Chemie und Mineralogie von Jacob Berzelius, XXIV, J, 300-301. Tübigen, 1845. (Analysis of Brazilian amethyst. In the original article there is no statement about these ninerals coming from Brazil.

HELMREICHEN, VIRGII VON: Reisebericht aus Minas Geraes vom $6 \mathrm{Mai}$, 1846, Berichte uber d. Mittheilungen von Freundell d. Naturwissenschaft in Wien. Vienna, 1847, II, 137-151.

HELMREICHEN, VIRGII VON: Ueber das geonostische Vorkommen der Diamanten und ihre Gewinnungs-Methoden auf der Serra do Grão Mogor. Vorworte w: Haidinger. Wien, 1846. Extract: Bull. Soc. Géol., 2me série, IV, 157. Paris, 1847. Reference, I, 2e série, 19.

HEMPEL, Dr.: (Analysis of magnesian limestone from S. Paulo.) Annales de la Soc. Géol. de Belgique. $4^{\circ}, \mathrm{XXV}$, bis 1er livraison, 42 Liège, 1900.

HENSEL, Dr. REINHOLD: Beiträge zur näheren Kenntniss der brasilianischen Provinz São Pedro do Rio Grande do Sul. Zeitschrift der Gesellschaft für Erdkunde zu Berlin, II, 227-269, 342-376. Berlin, 1867.

HENWOOD, WM. JORY: Descriptive notice of the Morro Velho Mine, Province of Minas Geraes; and on the relations between the structure of the containing rocks and the directions of the shoots of gold in the Brazilian mines. Transactions of the Royal Geological Socicty of Cornuall, VI, 143-146, $8^{\circ}$. Penzance, 1846. Also Philosophical Magazine, XXV, 341344. London, 1844.

HENWOOD, WM. JORY: Notice of the Itabira and Santa Anna Mines in Brazil. Transactions of the Royal Geological Society of Cornwall, VI, 227-229. $8^{\circ}$. Penzance, 1846.

HENWOOD, WM. JORY: Notice of the Descoberta Gold Mine in Brazil. Transactions of the Royal Geological Society of Cornucall, VI, 294-295. $8^{\circ}$. Penzance, 1846.

HENWOOD, WM. JORY: Abstract of a memoir on the metalliferous (gold) deposits of Brazil. Fdinburgh New Philosophical Journal, L, 61-64. Edinburgh, 1851.

HENWOOD, W. J.: On the geological association of tellurium. Trans. Roy. Geol. Society of Cornwall, VII, 228-229. Penzance, 1865.

HENWOOD, WILLIAM JORY: Observations on metalliferous deposits on the gold mines of Minas Geraes in Brazil. Trans. Royal Geol. Soc., Cornwall, VIII, part I, 168-370. $8^{\circ}$. Penzance, 1871.

HENWOOD, WM. JORY: Observations on subterranean temperature. Transactions of the Royal Geological Society of Cornuall, VIII, part II, 725732. Penzance, 1871.

HENWOOD, WM. JORY: On the changes in temperature which take place at the same, and at different times on the surface and at depths of three, six and nine feet in the Canga at Agoa Quente, in Brazil. Transactions of the Royal Geological Society of Cormuall, VIII, part II, 767-780. Penzance, 1871.

HERMANN, R.: Uber den Hydrargillit von Villa Rica in Brasilien. Erdmann und Werther, Journal für praktische Ohemie, no. 2, 1869, 72-73.

HERMETO, HONORIO: The Abaeté River, Minas. Brazilian Mining Review, I, 202-203. Rio de Janeiro, April, 1904. 
HETTNER, ALFRED: Das südlichste Brazilien (Rio Grande do Sul). Zeitschrift der Gesellschaft für Erkunde zu Berlin, XXVI, 85-144. $8^{\circ}$. Berlin, 1891. Geological maps and section.

HETTNER, ALFRED: Reisseskizzen aus Sïdbrasilien. I, Ein Besuch in den deutschen und italienischen Colonien bei Porto Alegre in Südbrasilien. Deutsche Rundschau für Geographie und Statistik, XIV, Heft V, Februar, 1892, 193-202; II, Besuch der Kohlenmine von Arroyo dos Ratos und der Colonien Estrella und Santa Cruz, 253-261. Wien, 1892.

HETTNER, A.: Das Deutschtum in Südbrasilien. Geog. Zeitschrift, VIII, 609-626. 1902.

FHUSSER: Ein Beitrag zur Kentniss des Brasilianischen Küstengebirge. Zeitschrift der Deutschen Geologischen Gesellschaft, X, 412-422. Berlin, 1858.

HEUSSER, CH., u. CLARAZ, G.: Ueber die wahre Lagerstätte der Diamanten und anderer Edelsteine in der Provinz Minas Geraes in Brasilien. Zeitschrift der Deutschen Gesellschaft, XI, 448-466 (Bermerkungen von G. Rose, 467-472). Berlin, 1859.

HEUSSER, J. C., und CLARAZ, G.: Physikalische und geologische Forschungen im Innern Brasiliens. Petermann's Mittheillungen, Gotha, 1859, 447-468.

HEUSSER, CH., et CLARAZ, G.: Gisement et exploitation du diamant dans la Province Minas Geraes au Brésil. Extract p. M. Delesse from Ueber die wahre Lagerstätte der Diamanten $u$. anderer Edelsteine in der Provinz Minas Geraes in Brasilien, von Ch. Heusser u. G. Claraz in Zeitschrift der Deutschen Geologischen Gesellschaft, XI, 448-466. Bemerkungen zur vorstehenden Abhandlungen von G. Rose, ibidem, 467. Annales des Mines, 5e série, XVII, 289-299. Paris, 1860.

HEUSSER, J. CH., und CLARAZ, G.: Ein fernerer Beitrag zur Kenntniss des Brasilianischen Küstengebirgs. Vierteljahrschrift der Naturforschenden Gesellschaft in Zurich, X, 60-64. 8 $^{\circ}$. Zurich, 1865.

HINCHLIFF, THOMAS WOODBINE: South American sketches, or a visit to Rio de Janeiro, the Organ Mountains, La Plata and the Parana. London, 1863. Occasional observations on geology, 181-183, 216-217, 224, 252, 269, $275,291$.

HINTZE, CARL: Handbuch der Mineralogie. Leipzig, 1906. Brazil, Chalcedon, 1496. Brookit, 1558.

HUAWATSCH, C.: Der Raspit von Sumidouro, Minas Geraes (Brasilien). Centralblatt für Mineralogie, Geol. und Pal., No. 14, 422-427. Stuftgart, 1905.

HOCHEDER: Die ursprüngliche geognostische Lagerstätte der Diamanten in Brasilien. Amtlicher Bericht ueber die einundzuanzigste Versammlung deutscher Naturforsher und Aertze in Gratz, 1843. $4^{\circ}, 105-107$. Gratz, 1844.

HOFMANN, ERNST: Geognostische Beobachtungen, angestellt auf einer Reise um die Welt, in den Jahren 1823 bis 1826, nnter den Befehl des Russisch Kaiserl. Flott-Capitaines und Ritters, Herrn Otto von Kotzebue. Die Umgebungen von Rio de Janeiro. Karsten's Archiv. für Mineralogie, Geognosie, Bergbau und. Hïttenkunde, I, 2 Heft, 243-251. Berlin, 1829.

HOLME, R. F.: A journey in the province of San (sic.) Paulo, Brazil, in JulySeptember, 1885. Proc. Roy. Geog. Soc., IX, 108-114. London, 1887.

HOLMES, JOSEFH A.: Preliminary report on the operations of the fueltesting plant of the U. S. Geol. Survey at St. Louis, Missouri, 1905. Bul. 290, U. S. Geol. Survey, Washington, 1906. (São Jeronymo coals from Rio Grande do Sul; analyses, steaming and producer gas tests, pp. 231233.)

HOMEM DE MELLO: จ. MELLO, HOMEM DE.

HOOFF, H. L. VAN: The drainage question of the island Marajo, s'Gravenhage. Tidschrift van het Koninklijke Instituut van Ingeneeors te's Gravenhage (Verhandlungen), 22-26, 1900-1901. 
HORMEYER, Captain J.: Südbrasilien. Ein Handbuch zur Belehrung für Jedermann insbesondere für Auswanderer. $8^{\circ}$. Hamburg, 1857. I, Absch. Geographische Uebersichet von Südbrasilien, 1-10. II, Abschnitt. von den Naturprodukten. Mineralien, .19-22.

HOVEY, E. O.: Ueber Gangdiabase der Gegend von Rio de Janeiro und über Salit von Sala in Schweden. T'schermak's Mineralogische und Petrographische Mittheilungen, N. F., XIII, 1892, 211-221. Wien, 1892. Part on Brazil, 211-318. Separate. Wien. Abstract: Neues Jahrb. für Mineral., 1894, I, 80-81. Referate.

HOWORTH, HENRY H.: The glacial nightmare and the flood; a second appeal to common sense (etc.). In 2 vols. $8^{\circ}$. London, 1893 . References to Brazil, $270,272,273,278,491,495,498$.

HOWORTH, HENRY H.: The glaciation of Brazil. Nature, Oct. 26, 1893, XLVIII, 614. London, 1893.

HUBER, J.: Aperçu géographique de la région du Bas-Amazone. Bull. soc. Gégr:, Geneve, 1900-1901, XII, 49-63. Physical features of the Amazons below Obidos.

HUBER, J., et KRAATZ-KOSCHIAU, VON: Entre l'Océan et le Rlo Guama. Bulletin de la Soc. de Géogr., III, 123-132, 1ll. Paris, 1901.

FUBER, J.: Contribuição á geographia physica dos furos de Breves e da parte occidental de Marajō. Bol. do Museo Paraense, III, 447-498, ill. Pará, 1901. Abstract: Annales de Geographie, XII, 291. Paris, Sept., 1903.

HUBER, J.: V. KRAATZ, VON.

HULL, EDWARD: The Brazilian coal-fields. The Quarterly Journal of Science, 1, 387-390. London, 1864. In Portuguese-Jasigos de carvão de Pedra do Rio Grande do Sul e Santa Catherina. O Auxiliador ala Industria Nacional, 1865, 236-242. Rio de Janeiro, 1865.

HULL, EDWARD: The Brasilian coal-fields. Note from The Quarterly Journal of Science, No. 2, V, I, 387-390, ill. April, 1864. Appendix $\mathrm{H}$ of "Brazil and the Brasilians." By Rev, James C. Fletcher and Rev. D. P. Kldder, 9th ed., 635-637. London, 1879.

HUMBOLDT, F. A.: Esquisse d'un tableau géologique de l'Amerique meridlonale. Journal de Physique de Chimie, d'Histoire Naturelle et des Arts, LIII, 30-60. Paris, an. IX de la République (1801, v. s). [This article is the original from which the one in the next title in German, published in Allg. Geog. Ephemeriden, was taken.]

HUMBOLDT, F. A. VON: Skizze eines geologischen Schllderung des Stldilchen Amerika. Allgemeine Geographische Ephemeriden. Verfasset von einer Gesellschaft Gelehrten und herausgegeben von A. C. Gaspari und F. J. Bertuch, IX, 310-329, 389-420. Weimar, 1802. Abstract: Annalen den Berg. und Hütenkunde von C. E. F. von Moll, II, 22-69. Salzburg, 1803.

HUMBOIDT, ALEXANDRE DF: A geognostical essay on the superposition of rocks in both bemispheres. Translated from the original French. London, 1823. Eschwege's views on the rocks of Minas Geraes are given on pp. 116-122.

HUMBOLDT, A. VON: Verkommen des Platins und Palladiums in Brasilien. Schweigger's Journal fïr Chemie, XLV, 45. Nuremburg, 1825. Also in Pogg. Annalen, VII, 519, 1826.

HUMBOLDT, ALEX. DE: Note sur le platine en Amérique, communiquée a l'Acad. Roy. des Sci., séance du 17 juillet, 1826. Le Globe (Paris), 20 juillet, 1826. Bull. des Sci. Nat. et de Géol., No. 11, 505-507. $8^{\circ}$. Parls, Nov., 1826.

HUMBOIDT, ALEXANDRE DE: Personal narrative of travels to the equlnoctial regions of the new continent during the years 1799-1804; by Alexander de Humboldt and Aimé Bonpland, with maps, plans. etc., written in French and translated into English by Helen Maria Williams. $\mathbf{8}^{\circ}$, VI, part II. London, 1826. Geology of the northern part of South America, 391-461. 
HUNT, T. STERRY: The decay of rocks geologically considered. American Journal of Science, XXVI, 190. New Haven, 1883.

HUNTER, M.: V. ROSENBUSCH and HUNTER.

HURE, Comte DE LA: V. BARIL, V. I.

HUSSAK, E.: Notas petrographicas sobre os augito-porphyritos do Paranapa. nema. Boletim n. 2, da Conmissño Geographica e Geologica da Provinci: de S. Paulo, 35-39. $8^{\circ}$. S. Paulo, 1889.

HUSSAK, E.: Ueber Leucit Pseudokrystalle in Phonolith (Tinguait) der Serra de Tingua, Estado do Rio de Janeiro, Brazil. Neues Jahrbuch für Mineralogie, 1890, I, 166-169. Briefliche Mittheilungen.

HUSSAK, E.: Contribuições mineralogicas e petrographicas. I, Notas sobre zeolitas do Augito-Porphyrito de S. Paulo e Sta. Catharina. II, Estudo de um cascalho aurifero virgem do Valle da Ribeira. III, Psendo-crystaes de leucita em phonolito (tinguaito) da Serra do Tingua. IV, Interessante endomorphose por acção de contacto de augito-porphyrito com grez; Rio Tieté, Estado de $\mathbf{S}$. Paulo. V, Phyllitas e com magnetita do Estado de São Paulo. VI, Noticia resumida sobre a occurrencia de corindon em S. Paulo. São Paulo, 1890. Bol. da Com. Geog. e Geol. do Estado de S. Paulo, n. 7, 3-40. Abstract in Amer. Jour. Sci., 3d series, XLIII (CXLIII), 1892, 77-79. Abstract: Zeitschrift für Krystallographie und Mineralogie, XXI, 405, 408. Leipzig, 1893.

HUSSAK, E.: Mineralogische Notizen aus Brasilien, Brookit, Cassiterit, Xenotim, Monazit und Euklas. (Part I.) Tschermak's Mineral. u. Petrogr. Mitth., N. F., XII, 357-375. Wien, 1891. Abstract: Zeitschrift fïr Kry\&t. und Min. (Groth), XXIV, 429-430. Leipzig, 1895.

HU88AK, F.: Ueber cubischen Pyrop und mikroscopische Diamanten aus diamantfiihrenden Sanden Brasiliens. Annalen des $K$. $K$. Naturhistorischen Hofmuseums, IV, 113-115. Vienur, 1891.

HUssAK, E.: I, Ueber Brazilit, ein neues Tantal-(Niob-) Mineral von der Elsenmine Jacupiranga. Süd-São Panlo, 141-146. II, Ueber brasillanlsche Leucitgesteine, 146-158. III, Nochmals die Leucit-Pseudokrystall-Frage. Neues Jahrbuch für Mineral., 1892, II, 141-159. Abstract in Amer. Jour. Sci., XLV (CXLV), 164-165. New Haven, 1893.

HUSSAK: Sobre o deposito diamantifero de Agua Suja, perto de Bagagem. Minas Geraes. Relatorio parcial da Commissão exploradora do planalto central do Brazil, pelo Dr. Luiz Cruls, 105-128. Rio de Janeiro, 1893.

HUSSAK, E.: Ueber Brazilit. Neues Jahrbuch für Mineralogie, 1893, II, 89. Bliefliche Mittheilungen. Abstract: Zeitschrift für Kryst. (Grotb), XXIV, 164-166. Leipzig, 1895.

FU8SAK, E.: Mineralogische Notizen aus Brasilien (Part II). 6. Ueber den Baddelyit (Syn. Brazilit) von der Eisenmine Jacupiranga in São Paulo (395-411.) 7 . Ueber Schwefelkrystalle in zersetzten Pyriten der Uingebung von Ouro Preto in Minas Geraes (411-412). 8. Ueber Slsoroditkrystalle von der Gold Mine Antonio Pereira bei Ouro Preto (412-413). 't'schermal's Miner. u. petr. Mitth., N. F., XIV, 1894. 395-413. (2 plates.) Wien, 1895. Abstract of N. 6: Mineralogical Mag. and Jour. Miner. Soc., 1895, XI, N. 50, 110-111. Abstract of N. 6: Neues Jahrbuch für Mineral., 1896, I, 214-216. Abstract: Zeitschrift für Krystalog. und Mineral., XXVII, 32t-325. Leipzig, 1897.

FUSSAK, E.: Ueber ein neues Perowskit-Vorkommen in Verbindung mit Mag neteisenstein von Catalão. Staat Goyaz, Brasilien. (Mit einem Holzschnitt.) Neues Jahrbuch für Nlineral., 1894, II, 297-300. Abstract: Magnetic iron ore in Brazil: Journal Iron and steel Institute, XLVII, 286287. London, 1895.

HUSSAK, E., and PRIOR, G. T.: Lewisite and zirkelite, two new Brazilian minerals. Mineralogical Magazine and Journal of the Mineralogical Soc., 1895, XI, 80-88. Reprint, 1-9. Abstract: Amer. Jour. Sci., 4th series, I (CII), 71-72. Neri Haver, 189G. 
HUSSAK, EUGENIO: Sobre a occurrencia de cinathrio em Tripuly, Minas Geraes. Revista Industrial de Minas Geraes. Anno IV, N. 23, 291-29;. Ouro Preto, 20 de Abril, 1897.

HUSSAK, E., and PRIOR, G. T.: On Tripulyyte, a new antimonate of iron from Tripuly, Brazil. Mineral. Mag. and Jour. Wineral. Soc., XI. 302, 1897. Separate. Abstract in Amer. Jour. Sci., 4th series, V, 1898 (CrV), 316. Abstract: Bulletin de la Soc. Françate te Minćralogie, XXI, 86. Paris, 1898. Abstract: Zeitschrift für Krystallog. und Mineral., XXXI, 185-186. Leipzig, 1899.

HUSSAK, E.: Ueber ein neues Torkommen ron Baddeleyit als accessorischer Gemengtheil der jacupirangitähnlichen basischen Ausscheidungen des Nelulinsyenites von Alnö, Schweden. Neucs Jahrbuch für Mincialogir. 1898 , II, 228-229.

HUSSAK, E., and PRIOR, G. T.: On Derbylite, a new antimonotitanite of irom from Tripuhy, Brazil. Alinepalogical Nlagasine, 1897. XI, x. 5*, 176-179. Reprint, 1-14. Abstract: Nenes Jahrbuch für Mineral., 189s. II, 196-107. Referate. Abstract: Bulletin de la Soc. Francaise de Minceralogie, XXI, 133-134. Paris, 1898.

HUSSAK, E.: Ueber eine merkwiirdige Cmwandlung und secundäre Zwillings-bildung des Brookits von Rio Cipó, Minas Geraes, Brazilien. Newcs Jahrbuch fiil Mineralogie, 1898, II, 99-101, plate. Stuttgart, 1898. Abstract: Zcitschrift für Krystallog. und Mineral., XXXIII, 180. Leipzig, 1900.

HUSSAK, E.: Das Zinnober-Vorkommen von Tripulny in Minas Geraes, Brasilien. Zeitschnift für praktische Geologie, Februar, 1897, 65-67. Berlin, 1897. Abstract: Zeitschrift fï Krystallog. und Mineral., XXXII, 185. reipzig, 1900.

HUSSAK, E.: Der goldführende, kiesige Quirzlıgergang von Passagem in Minus Geries, Brnsilien. Zeitschwift für praktische Goologie mit besonderer Beriicksichtigung der Talgerstättenkunde, Oktober, 1898, 345-357. figures. Berlin, 1898. Partial abstract by W. Lindgren: Transactions 1merican Institute of Miniug lingincers, 1900, XXX, 626-642. IIl. New York, 1901. Abstract: Zeitschrift für Krystallog. und Mineral., XXXIII, 207-208. Ieipzig, 1900.

HUSSAK, E., and PRIOR, G. T.: On Senaite, a new mineral belonging to the Ilmenite group f'rom Brazil. Mincralogical Magazine, June, 1898, XII, N. 54, 30-32. Iondon, 1898. Abstract: Bulletin de la Societé Francaise de Mincralogie, XXI. 178. Paris, 1898. Abstract: Zcitschrift für Krystallographie und Minciulogie, XXII, 272-274. Leipzig, 1900.

HUSSAK, EUGEN: Mineralogische Notizen aus Brasilien (Part III). 9. Tin Beitrag zur Kenntniss der sogenaniten "Favas" der braslianischen Dlamantsande, 334-341. 10. Die Mineralischen Begleiter" des bahianischen Diamants, 342-359. Tschermak's Mineral. ${ }^{2}$. petrograph. Mitth., N. F., XVII, 1898, 334-359. Wien, 1899.

HUSSAK, E.: Ueber ein leukokrates gemischtes Ganggestein der Serra de Caldas, Brasilien. Neues Jahrbuch für Miner., 1900, I, 22-27. Stuttgart, 1900.

HUSSAK, E., and PRIOR, G. T.: Florencite, a new hydrated phosphate of aluminium and the cerium earths from Brazil. Mineralogical Magazine, XII, N. 57, 244-248. Iondon, 1900. Abstract: Amer. Jour. Sci., CLX, 404. New Haren, 1900. Abstract: Zeitschrift für Krystallog. und Mineral., XXXVI. 165-166. (Grotl.) reipzig, 1902.

HUSSAK, E.: Ueber Chalmersit, ein neues Sulfid der Kupferglanzoruppe von der Goldmine "Morro Velho" in Minas Geraes, Brasilien. Centralblatt $f$. Min., G. u. Pal., 1902, N. 3, 69-72. Stuttgart, 1902. Abstract: English translation in Transactions of the Institution of Mining Engineers, $\mathrm{X} \times \mathrm{V}$, 793. Newcastle-upon-Tyne, 1904.

HUSSAK, E.: Nota sobre a chalmersita, mineral do grupo da Chalcosint, encontrado nal mina do Morro Vello. Annaes da Escola de Minas, No. B, 91-97. Ouro Preto, 1903. 
HUSSAK, E.: Sobre a raspita do Sumidouro, Este de Minas Geraes. Annacs da Wiscolt de Minas, No. 6, 99-103. Ouro Preto, 1903.

HUSSAK, E., und REITINGER, J.: Teher Monazit, Yenotim, Senait und natürliches Zirkonoxyd aus Brasilien. Zeitschrift für Krystal., XXXVII, 550-579. Ill. Ieipzig, 190\%. Abstruct: Mining Magazine, XIII, 398. Iondon, 1903.

HUSSAK, E.: Ueber den Raspit von Sumidouro, Minas Geraes. (Brasilien.) Centralblatt für Mineralogie, 1903, T2:3-7:-5. Stuttgart. 1903. Abstract: Zeitschrift für Krystal. und Mineral., XII, (44-(348. Ieipzig, 1906.

HUSSAK, E.: Ueber die Mikrostructur einiger brasilianischer Titanmagneteisensteine. Neues Jahrbuch für Mineralogie, Geologie und Paleontologie. Jalirgang, 1904. I Band, 94-113. Stuttgart, 1904.

HUSSAK, E.: Ueber das Verkommen von Palladium und Platin in Brasilien. Sitzungsberichten der $K$. Alcademie $d$. Wissenschaften in Wien. Math. nat. Klasse Bd., CXIII, Abb. I. Wien, Juli, 1904. Abstract under title: Occurrence of Palladium and Platinum in Brazil. Amer. Jour. Soi., CLXIX, 397-399. May, 1905.

FUSSAK, E.: Mineralogische notizen aus Brasilien. (thber einen neuen Chondritfall, nahe Uberaba in Minas Geraes, über Nephrit von Baytinga in Bahia und über Hamlinit aus diamant führenden Sanden von Diamantina, Minas Geraes.) Annalen des $K$. $K$. Naturhistorischen Hofsmuseums, XIX, Heft I, 85-95. Wien, 1904. Abstract: American Journal of Science, CLXIX, 202-203. Feb., 1905.

HUSSAK, E.: Ueber Atopit aus den Manganerzgruben von Miguel Burnier, Minas Geraes, Brasilien. Centralblatt für Mineralogie, Geologie und Paleontologie, 1905, No. 8, 240-245. Stuttgart, 1905.

HUSSAK, EUGEN: Ueber das Vorkommen von gediegen Kupfer in den Diabasen von São Paulo. Centralblatt für Mineralogie, Geologie und Paläontologie, 1906, No. 11, 333-335. Stuttgart, June, 1906.

HUSSAK, EUGEN: Ueber Gyrolith und andere Zeolithe aus dem Diabas von Mogy-guassú, Staat São Paulo, Brasilien. Centralblatt für Mineralogie, Geologie und Paläontologie, 1906, No. 11, 330-332. Stuttgart, June, 1906.

HUSSAK, EUGEN: Ueber die chemische Zusammensetzung der Chalmersit. Centralblatt für Mineralogie, Geologie und Paläontologie, 1906, No. 11, 332-333. Stuttgart, June, 1906.

HUSSAK, E.: tuber die Manganerzlager Brasiliens. Zeit. für Pralt. Geol., XIV, Juli, 1906, 237-239.

HUSSAK, E.: Utber das Verkommen von Palladium und Platin in Brasillen. Zeit. für Prakt. Geol., XIV, Sept., 1906, 284-293. 'Translated by M. A. R. Lisboa and published under the title, $O$ palladio e a platina no Brasil. Annacs da Escola de Minas de ouro Preto. no. 8, 77-188. Ouro Preto (1906). Separate. Resumé: liencs Jahrb. f. Min., II, 1905, 346-348.

HUSSAK, E.: Ưber die Diamantlager im Westen des Staates Minas Geraes und der angrenzenden Staaten São Paulo und Goyaz, Brasilien. Zeit. für Prakt. Geol., XIV, Okt,, 19nk, 318-333. -Abstract: Neues Jahrb. $f$. Min., 1908, I, 169.

HUSSAK, E.: Ưber die sogenannten "Phosphat-Favas" del diawant führenden Sande Brasiliens. T'schermals Mineralogische u. Pet. Mitteilungen. N. F., XXV, 335-344. Wien, 1906. Alstract: Bul. Soc. fr. de Mfineralogie, XXIX, 368-370. Paris, 1906.

HUSSAK, E.: Ueber Gyrolith und andere Zeolithe aus dem Diabas von Mogyguasśa, Staat São Paulo, Brasilien Ueber die Chemische Zusaumensetzung des Chalmersit Ueber das Verkommen von gediegen Kupfer in den Diabasen von São Paulo. Centralblatt für Min. Geol. u. Pal. Jahrg., 1906, no. 11, 330-335. Stuttgart, 1906.

HUSSAK, E.: v. OLIVEIRA. 
HUTTON, JAMES: Of the flexibility of the Brazilian stone. (Read Feb. 7, 1791.) Transactions of the Royal Society of Edinburgh, III, 86-94. Edinburgh, 1794. Under title of "Brazilian stone," quoted from Encyclopœedia Perthensis or Universal dictionary of arts, science, 2d ed., IV, 308-309. Edinburgh, 1816.

HYATT, ALPHEUS: Report on the Cretaceous fossils from Maroim, Province of Sergipe, Brazil. Hartt's geology and physical geography of Brazil, 385-393. Boston, 1870.

HYATT, ALPHEUS: The Jurassic and Cretaceous Ammonites collected li South America by Professor James Orton, with an appendix upon the Cretaceous Ammonites of Prof. Hartt's collection. Proc. Boston Soc. Nat. Hist., XVII, 365-372. Boston, 1875.

HYATT, ALPHEUS: Pseudoceratites of the Cretaceous. Monograph XLIV, U. S. G. S. Washington, D. C., 1903. Vascoceras Harttii from Sergipe, 103. Plate XIV.

IDDINGS, J. P.: Rhyolite tuff from Pernambuco. Bull. Geol. soc. Amer. vol. 13, 84! Rochester, 1902.

IHERING, H. VON: Die Lagoa dos Patos. Deutsche Geogr: Blätter. Bremen, VIII, $193 \mathrm{ff}, 1885$.

IHERING, H. 'VON, und LANGHANS, P.: Das südliche Koloniengeblet rou Rio Grande do Sul. Petermann's Mittheilungen, XXXIII. 289-302, 2 Karten, 328-343. Gotha, 1887.

IHERING, H. VON: On the ancient relations between New Zealund and South America. Transactions of the New Zealand Institute, 1801, XXIV, N. 18, 431-445. Auckland, 1891.

IHERING, H. VON: Sobre las antiquas conexiones del continente Sud-Ameri cano. Revista Argentina de Historia Natural, I, 121-122. Buenos Aíres 1891.

THERING, H. VON: Nuevos dados sobre las antiquas conexiones del conti nente Sud-Americano. Revista Argentina de Historia Natural., I, 280-282 Buenos Aires, 1891.

IHERING, H. VON: Die Insel Fernando de Noronha. Globus, LXII, N. 1F 225-230. Braunschweig, 1892.

IHERING, H. VON: Ueber Binnen Conchylien der Kiistenzone von Rio Grand, do Sul. Archiv f. Naturg., LX, 37-40. Berltn, 1894.

IHERING, H. VON: As ilhas oceanicas do Brazil. A ilha de Feruando de Noronha. Revista Brazileira, Outubro de 1895, IV, 101-108; Nov. de 1895, IV, 164-173. Rio de Janeiı,o, 1895.

IHERING, H. VON: As ilhas oceanicas do Brazll. Trindade. Revista Bril. zileira, III, 256-260. Rio de Janeiro, Agosto de 1895.

IHFRING, H. VON: A Ilha de São Sebastião. Revista do Museu Panlista, II, Geologia, 145-148. S. Paulo, 1897.

IHFRING, H.: Os molluscos marinos do Brazil. Revista do Museu Paulista, II, 73-113, 7 figs. São Paulo, 1897.

IHFRING, H. VON: Observaçōes solbre os peixes fosseis de Taubaté. Revista. do Museu Pautista, III, 71-75. S. Paulo, 1898. Abstract: Neues Jahrbuch für Mineral., 1901, II, 149. Referate.

IHERING, H. VON: Die Conchylien der potagonischen Formation. Neues Jahrbuch für Mineral., 1899, II, 1-46. Stuttgart, 1899.

IHERING, VON: The history of the neotropical region. Science, XII, N. 81i, 857-864. New York, Dec. 7, 1900.

IHERING, H. VON: A origem dos sambaquis. Revist. Inst. Hist. e Geoys: de S. Paulo, VIII, 446-457. S. Paulo, 1903.

IHERING, H. VON: Archeologia comparativa do Brazil. Revista do Museu Paulista, $\mathrm{V}_{1} \mathrm{I}$, 519-583. São Paulo, 1904. Sambaquis, 529 et seq. 
IMPERIAL BRAZILIAN MINING ASSOCIATION: Reports of the directors addressed to the shareholders, etc. The 1st report, London, 1826, to the 31st report, London, 1841. $8^{\circ}$. 'These reports are by many authors, and contain many notes upon the geology of the mines in Minas Geraes. 'The serond annulal report is dated Iondon, 1827 , and treats especially of the? Gongo soco mining properties.

IMPERIAL INSTITUTE of the United Kingdom, the Colonies and Indil. (Allalysis of) coal from Santa Catherina.. . Technical Reports and Scientific I'apers. Edited by IV. R. Dunstan, ete. $8^{\circ}$. London, $190 \mathrm{H}$. 'The analysis at page 9 is by $G$. S. Blake.

IMRAY, J. F., and JENKINS, H. D.: Atlantic Ocean Pilot.-The seaman's guide to the navigation of the Atlantic Ocean. $8^{\circ}$. London, 1883. 'Trinidilde and Martin Ta\%, 194-196.

ISABELLE, ARSENE: Excursions dans la province de Rio Grande do Sul alı Brésil (18:34). Extrait d'un voyange inédit. Nouvelles Annales des Volyagcs, IXV, 257-279. Paris, 1835. Géologie, 262 et scq.

ISABELLE, ARSine: Voyage à Buenos-Ayres et á Porto Alegre, por la Bandil-Oriental, les Missions d'Uruguay et la province de Rio Grande do Sul. (1830-1834), etc. $8^{\circ}$. Le Havre, 1835. Review: Nouvelles Annales des Voyagcs, LXIX, 235-248. Paris, 1836.

JACOB, RODOLPHO: Totas geognosticas o montanisticas sobre als lavias do omo de Minas Geraes. Traducgĩo do Cap. 50, parte $3 a$ do "Pluto Bra" silienses" (sic.) obra escripta em allemão pelo Bario G. de Eschwege. Revista do Archivo Publico Afineiro, anno II, fasciculo 4; Out. a Dez. de 1897. Ouro Preto, 1897.

JACOB, RODOLPHO: Occurrencia e jazidas do ouro. 'Traducção do Calp. I, parte III do "Pluto Brasiliensis" (de Rschwege). Revista do Archivo Publico Minciro, anno III, fas. III e IV, 1898, 519-577. Bello Horizonte, 1898 .

JACOB, RODOLPHO: IIistoria da extracçĩo e lavagem do ouro en Minas Gerates. Tradução do Cap. 2, parte 1 do "Pluto Brasiliensis" obra escrijta en Allemño velo Barĩo G. de Eschwege. Revista do Archivo Publico Minciro. Anno III, fas. II, 1898, 433-463. Bello Horizonte, 1898.

JACOBS, H., et CHATRIAN, N.: Monographie du-diamant. Anvers et Pillis, 1880. Chapitre III. Gisements du diamant, 62 et seq.; mines du Brésil. 7i-117.

JAMESON, Professor: Extracts from a jourmal written on the consts of Chili, I'eru and Mexico, in the years 1820, 1821, 1822. By Captain Basil Hall. Vol. II, 3d ed. Edinburgh, 1824. List of minerals collected on the shores of South Americal and Mexico. Rocks and minerals from Rio de Janeiro and Bahia, 1) 65 of the appendix.

JANNASoH, F.: Eine Neue Analyse des Spodumens von Brasiliens. Neucs .Jahrbuch fïr l/inerul., 1888, T, 196-201. Abstract: Bull. Soc. Française de Minćlalogie, 1888, XI, 200-201. Abstract: Zeitschrift für Krystallographie uml Minciulogic, XVII, 313. Jeipzig, 1890.

JANNASCH, P., und CALB, G.: Ueber die Zusammensetzung des Turmalines. Berichte der deutschen Chemischcn Gesellschaft, XX, 216-221. Berlin, 1889. Abstract: Zeitschrift für Ir'ystallographie and Mineralogie (Groth), XIX, 631. Leipzig, 1891.

JANNASCH, P., und LOCKE, JAMES: Chemische Untersuchung des Topases. Zeit. fül Allong. Chemie, VI, 168-173, 321-326. Hamburg und Leipzig, 189 . Alsstract: Zeitschrift fïr Krystallog. und Mineralog. (Groth), XXVI, (i)it-635. Leipzig, 1896.

JANNETAZ, ED., EM. VANDERHEYM, A., COUTANCE et E. FONTENAY: I Diamint et pierres précieuses. $8^{\circ}$. Paris, 1881. Brésil, 190-195, 241-242. $29: 2$.

JARDIM, CATÃo GOMES: A região de Diamantina (Minas Geraes). suns riquezas natmaes e seus recursos. Revisla Industrial de Minas Geraes, ammo III, N. 16, 15 de Abril de 1896, 117-121; N. 17, 15 de Maio de 1896, 181-191. Onro Preto, 1896. 
TEFFRIES, DAVID: A treatise on diamonds and pearls in which their inportance is considered, etc. Fourth ed. $8^{\circ}$. London (n. d.). Remarks on Brazil diamonds, 51-67.

JENKINS: See Imray.

JENZSCH, GUSTAVE: Considérations relatives a la partie minéralogique des instructions pour l'exprdition scientifique Brésilienne. Lettre adressée a Monsieur le Chevalier de Sturz, Consul Général d l'Empire du Brésil. Imprimée comme nuanuscrit. $8^{\circ}, 12 \mathrm{pp}$. Dresde, 1857.

JENZSCH, GUSTAV: Mineralogische Notiz über die Fxpedition der Herren W. Schultz und Freiherrn O Byrn nach Südbrasilien. Beilage to W. Schultz's Studien ïber agrarische und Physikalische Verhältnisse in Siidbrasilien. 209-244. Leipzig, 1865.

„TFNZSCH, Dr.: (Geologischen Resultate von Schultz und O Byrn in Südbrasilien.) Amtlicher Bericht über die Noun und Dreissigste Versammlung Deutscher Natw'forscher und Arzte in Giessen im Sept., 1864. $4^{\circ}$, 137. Giessen, 1865.

TFREMEJEW, P. v: [Crystals of bort and carbonado from Brazil.] Bulletin de l'Académie Impériale des Sciences de St. Petersbourg. Ser. V, VIII, pp. XXX-XXXII. St. Petersbourg, 1898. [In Russian.] Abstract: Zeitschrift für Krystallographie und Mineralogie (Groth), XXXII, 424. Leipzig, 1900 .

JERRMANN, L.: Diamantino, an der Grenze der Zivilisation. Peternann's dlittleilungen, XLIX, 145-149, map. Gotha, 1903.

JOAQUIM CANDIDO: v. SENA, COSTA.

JoHNSON, P. N., und LAMPADIUS, W. A.: Ueber brasilianisches Palladgold und dessen Ausbringen und Scheidung. Journal fïr pratitische Chemie, 1337, II. 309-315. Leipzig, 1837.

JONES, T. RUPERT: On the discovery of some fossil remains near Bahia in Soutl America. By S. Allport. Note on the fossil Entomostraca from Montserrate Bahia. Quart. Jowr. Geol. Soc., Dec., 1859, XVI, 266-268. London, 1860.

JONES, T. RUPERT: On some Fossil Entomostraca from Brazil. Geological Magazinc. New Ser. (4) May, 1897, IV, 195-202, 1 pl. ; also July, 1897, IV, 289-203, 2 plates. London, 1897. Abstract: Neues Jahrbuch für Mineral., 1898. I. 555. Referate.

JORDAN, DAVID STARR: The fossil fishes of California, with supplementary notes on other species of extinct fishes. Bul. Dept. Geol. Univ.

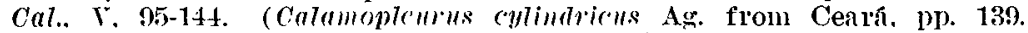
Eobrycom avus from 'Taubaté, S. Paulo. p. 140.) Berkeley, 1907.

JORDAN, DAVID STARR, and BRANNER, JOHN CASPER: The Cretaceous fishes of Cearâ. Smithsomian Misc: Collectiom, no. 1793, LII, 1-29. Washington, 1908.

JORDANO MACHADO: v. MACHADO, J.

JORDÁ, J. NABôR PACHECO: Carvão de pedra do Brazil. O Novo Mundo, VII, 19. New York, 187t. Analyses.

JOSE AMERICO DOS SANTOS: v. SANTOS, J. A. DOS.

JONN亡S, ALEXANDRE MOREAU DE: IIistoile physique des Antilles Francaises; savior; La Martinique et les iles de la Guadaloupe. $8^{\circ}$. Paris, 1822. Brésil, 38-40, 49-52.

KARSTEN: Ueber das Erz-fïllrende-Kalkstein-Gebirge in der Gegend von Tarnowitz. Abhandl. d. h. Aknd. d. Wissensch. $z u$ Berlin ron 1827. Physik. Klasse, Berlin. 1830, 1-72. Taf. I-III. Abstract: Neues Jahrb. $t$. Mineral., 1834, 594-605. Analysis of dolomite from Minas Geraes, 604.

KARSTEN, H.: Geognostische Verhaltnisse des nordlichen Theiles der Cordilleren Sïd-Amerika's und der daran grenzenden Ebenen des Orinoko- u. Amazonen-Stromes. Tageblatt d. Tersamm. Deutsch. Natwif. und Arate.

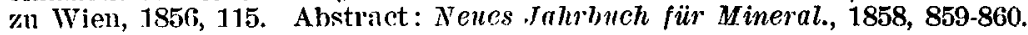


KARSTEN, HERMANN: Géologie de l'ancienne Colombie bolivarienne, Vénézuela, Nouvelle-Grenade et Ecuador. $4^{\circ}$, avec 8 planches et une carte geologique. Berlin, 1886. The geological map colors geologically the Amazonas region west of Manaos.

KATZER, FRIFDRICH: Phytopaleontologische Notizen. Sitzber, d. Kgl. böhm Gesellsch. der Wissenschaften, Nr. XII, 1-7. Separate. Prag, 1896.

KATZER, FRIEDRICH: As camadas fossiliferas mais antigas da região Amazonica Boletim do Musen Paraense, I, n. 4, 436-438. Para, 1896.

KATZER, FRIFDRICH: Beitrag zur Kenntniss des älteren Paleozoicums Im Amazonasgebiete. Sitz-Ber, d. Kgl. böhm. Gesellsch. der Wissenschaften. matl. nat. Classe, Nr. XXIX, 1896, 23-25. 3 Taf. Prag, 1896. Abstruct: Neues Jahrbuch für Mineralogie, Geologie und Paleontologie, I, 509, 1899.

KATZER, FRIFDRICH: Das Amazonas-Devon und seine Beziehungen zu den auderen Devongehieten der Erde. Sitz.-Ber. böhm. Ges. Wiss. Math. naturw. CL, N. 46, 50 pp. 1 Karte. $8^{\circ}$, Jahrg., 1897, II, Art. xlvi. Prag, 1898. Referate: Neues Jahrbuch für Mineral., 1899, II, 447-449.

KATZER, FRIEDRICH: Ueber das Carbon von Itaitába am Tapajos-Flusse in Brasilien. Neues Jahrb. $f$. Mineral., 1897, II, 218-220. Briefliche Mittheilungen.

KATZER, FRIEDRICH: A foz do Tapajós e suas relaçóes com a agua subterranea na região de Santarém. Boletim do Museu Paraense, II, n. 1, 78-96. Pará, 1897.

KATZER, FRIEDRICH: Das Wasser des unteren Amazonas. Sitzungsberichte der königlich-böhmischen Gesellschaft der Wissenschaften, Mathem.naturwissenschaftliche Classe, 1897, Nr. XVII, 1-38. Prag, 1897. Abstract: Neues Jahrbuch für Mineral., 1898, II, 258. Referate: Petermann's geographische Mitteilungen, 1898, XLIV. Literaturbericht, 68.

KATZER, FRIEDRICH: Der strittige Golddistrikt von Brasilianisch-Guyana. Oesterreichische Zeitschrift für Berg- und Hïttenwesen, 29 Mai, 1897, XLV, N. 22, 295-300, small map. Separat. Wien, 1897. 3-16, Globus, LXXIV, no. 9, 1898. Abstract: Neues Jahrb. für Mineral., 1898, II, 264265. Referate: Zeitschrift für praktische Geologie, 1897, V, 422. Petermann's geographische Mitteilungen, 1897, XLIII. Literaturbericht, 187.

KATZER, FRIEDRICH: A fauna devonica do Rio Maecurú e as suas relaçōes com a fauna de outros terrenos devonicos do globo. Boletim do Museu Paraense, II, 204-246, 1 mappa. Parn, 1897. Referate: Neues Jahrbuch für Mineral., 1899, II, 447-449. Petermann's geographische Mitteilungen, 1898, XLIV. Literaturbericht, 136.

KATZFR, FREDERIC0: Relatorio resumido sobre os resultados geologicos praticos da viagem de exploração ao Rio Tapajos e ḱ região de Monte Alegre, feita por ordem do Exm. Sr. Governador do Estado Dr. José Paes de Carvalho, de Setembro a Novembro de 1897. Boletim do Museu Paraense, Agosto, 1901, III, N. 2, 134-165. Pará, 1901. Referate: Petermann's geographische Mitteilungen, 1902, XLVIII. Literaturbericht, 77.

KATZER, FREDERICO: Relatorio resumido sobre os resultados geologicos praticos da viagem de exploração ao rio Tapajos e a região de MonteAlegre. (De Setembro a Novembro de 1897.) Belem, Typ. do Diario Official, 1898.

KATZER, FRIFDRICH: Ein eigenthïmliches Manganerz des Amazonas-Gebietes. Osterr. Zeitschr. f. Berg- und Hïttenwesen, XLVI, No. 4, 41-46, one plate. Sep. Abdr. 16 pages, ills. Wien, 1898. Referate: Neues Jahrbuch für Mineral., 1900, I, 411. Zeitschrift für praktische Geologie, Jahrgang, 1898, VI, 266.

KATZER, F.: Eine Forschungsrelse nach der Insel Marajo. (Amazonasmundung.) Globus, LXXIII, nos. 5, 6, 7. 1898.

KATZER, FRIEDRICH: Die Stromenge des Amazonas bel Obydos. Globus, LXXIV, 47, 1898. 
KATZER, FRIEDRICH: Auf der Lagerstättènsuche im unteren Amazonasgebeite. Oesterr. Zeitschrift für Berg- und Hüttenwesen, XLVI, 479-483, 500-503, 515-518. Sarajevo, 1898. Separat, Sarajevo, 32, 1898. Abstract: Zeit. fii Kryst. u. Min., XXXIII, 202. Leipzig, 1900. Referate: Petermann's geographische Mitteilungen, 1898, XLIV. Literaturbericht, 208.

KATZER, FR.: Silur in Brasilien. Neues Jahrbuch für Mineralogie, 1899, 1, 257-259. Stuttgart, 1899.

KATZER, FRIEDRICH: A medição geographica do Pará. Revista Brazileiru, XVIII, 52-69, 1899. Rio de Janeiro, 1899.

KATZER, FRIFDRICH: Ueber die rote Farbe von Schichtgesteinen. Neuri Jahrbuch für Mineralogie und Geologie, 1899, II, 177-181.

KATZER, FRIEDRICH: Zur Geographie des Rio Tapajos. Globus, Nov., 19u0, I.XXVIII, 281-284. Braunschweig, 1900. Abstract: Geographical Jourual, London, XVII, 194-195. Iondon, 1901.

KATZER, FRIEDRICH: Das Gebiet an der Mündung des Trombetas in den Amazonas. Petermann's Mittheil, XLVII, 49-53. Gotha, 1901.

KATZER, FRIEDRICH: Zur Frage der Entstehung und Einteilung der brasilischen Campos. Petermann's Geogr. Mittheilungen, XLVIII, 190-191. Gotha, 1902.

KATZER, F.: Der landschaftliche Charakter von Ceara (Brasllien). Globus, LXXXII, 1-5 mit 4 abb. 3 Juli, 1902. The original article was translated by Capistrano de Abreu and published under the title Paizagens do Ceará. Revista T'rimensal do Instituto do Ceará, XVII, 291-298. Fortaleza, 1903. Abstract: Neues Jahrbuch für Mineralogie, Geol. und Paleontologie, $1908,250$. Stuttgart, 1903.

KATZER, FRIEDRICH: Grundzüge der Geologie des unteren Amazonas Gebietes (des Staates, Pará in Brasilien). 301 pp., $8^{\circ}, 1$ geol. map, 4 parts, 16 pl. fossils. Max Weg, Ieipzig, 1903. Review by J. C. Branner. Journal of Geology, XII, 278. Chicago, 1904. Abstract: Neues Jahrbuch für Mineral., Geol. und Paleontol., 1904, I, 420-426. Stuttgart, 1904. Review : Zeitschrift fiir Prakt. Geol., XII, 104, 105, March, 1904. Quotation: Mineralquellen. etc. Zeit. für prakt. Geol., XII, 57-58. Berlin, 1904. Review: Geog. Jour., XXV, 559, May, 1905.

KATZER, F.: Beitrag zur Geologie von Ceara (Brazilien). LXXVIII Bande der Denkschriften der Math.-Nat. Wissn. Klasse der K. Akad. der Wiss. Wien, 1905.

KATZER, F.: Ueber einen Brazil-Monazitsand aus Bahia. Osterreich Zeitschrift für Berg- und Hüttenuesen, I,III, 231-234, 1905. Abstract: Nelles Jahrb. f. Min., II, 1906, 343-344.

KAYSER, E.: Beiträge zur Kenntniss einiger palaeozoischer Faunen SüdAmerikas. Zeitschrift der deutschen geologischen Gesellschaft, 1897, XLIX, 314317. Berlin, 1907.

KAYSER, E.: Ueber das Alter des argentinischen Devon. Neues Jahrb. für. Mineral., 1899, I, 255-7. Stuttgart, 1899.

KAYsER, E.: Alguns fosseis paleozoicos do Estado do Paraná. 2 plates. Revista do Museu Paulista, IV, 301-311. S. Paulo, 1900. Devonian invertebrates.

KEANE, A. H.: Central and South America. Vol. I of Stanford's Compendium of Geography and Travel (new issue), edited by Sir Clements R. Markham, maps and illustrations. London, 1901. Chaps. X'IV and XV, 486592, on Brazil. Geology, 504-507.

KELLER, FRANZ: Geologische Beobachtungen auf Wanderungen im Innern Brasiliens. (Aus einem Privatbrief von Herrn Franz Keller an Prof. Bernh. v. Cotta in Freiburg.) Ausland, XL, No. 51, 1220-1222, ill. Augsburg, 17 Dez., 1867.

KELLER, FRANZ: Aufnahmen in Süd-Amerika und die Eisenbahn längs des Madeira-Stromes. Petormann's Mittheilungen, XIX, 410-413. Gotha, 1873. 
KELLER, FRANZ: 'The Amazon and Madeira Rivers. Sketches and descriptions from the note-book of an explorer. By Franz Keller, Engineer. With sixty-eight iflustrations on wood, $4^{\circ}, \mathrm{XVI}+177$. New York, 1874. Notes on the geology.

KELLER, Jost and FRANCISco: Exploração dos Rios Tibagy e Peranapalnéma. Annexo (letra $\mathbf{N}$ ) ao Relatorio do Ministro de Agricultura, etc., p. 25. Rio de Janeiro, 1866.

KELLER, JOSE e FRANCISCO: Exploração do Rio Madeira ua parte comprehendida entre a cachoeira de Santo-Antonio e a barra do Mamoré. Noçōes geologicas, 23-27. Annexo $\mathrm{X}$ do Relatorio, etc., $4^{\circ}$. Rio de Janeiro, $1870(?)$.

This article is translated under the following title: Exploration of the River Madeira. Report of José and Francisco Keller made to the Inperial Government of Brazil, and published in the government "Relatorio" of 1870. Translated from the Portuguese by George Earl Church, etc. $8^{\circ}, 71 \mathrm{pp}$. London, 1873 . Geology, 28-33.

KELLER-LEUZINGER, FRANZ: Vom Amazonas und Medeira Skizzen und Beschreibungen aus dem 'Tagebuche einer Explorationsreise. $4^{\circ}$. Stuttgart, 1874. Same as the title above.

KEMP, J. F.: (Description of gneiss from Pedreira da Gloria, Rio de Janreiro, Brazil.) Bul. Geol. Soc. Amer., VII., 283-284. Rochester, 1896.

KEMP, J. F.: Geologic relations and distribution of platinum and associated metals. Bul. 193, U. S. Geol. Sur., Washington, 1902. (Brazil, 31-60.)

kENNGOTT, A.: Ueber Euklas, Topas, Diamant and Pyrrhotin aus Brasilien. Neues Jahrbuch fïr Mineral., 1884, I, 187-191. Briefliche Mittheilungen. Stuttgart, 1884.

KENNGOTT, A.: Nephrit von Jordansmühl in Schlesien. Magnetismus des Tigerauges. Topas von Ouro Preto. Neues Jahrbuch für Mineral., 1885, I, 239-240. Briefliche Mittheilungen. Abstract: Zeitschrift für Krystallograpluie und Mineralogie (Groth), XII, 317. Leipzig, 1887.

KENNGOTT, A.: Ueber Pyrophysalith von Finbo, Augit von Risoe und Martit von Ypanema. Neues Jahrbuch für Mineral., 1890, I, Martit von Ypanema, 91-92. Briefliche Mittheilungen.

KERNER, F. VON: Mitteilungen über Reisen im Staate São Paulo. (Aus Briefen an Herrn Hofrath Stache de dato São Paulo, 25 Juni and Anfangs August u. 15 September.) Verhandlungen der $K$. K. geol. Reichsanstalt, $1901,248-250,273$.

KIDDER, DANIEL: Sketches of residence and travels in Brazil, embracing historical and geographical notices of the Empire and its several provinces. 2 vols., ill., $8^{\circ}$. Philadelphia, 1845. Fabrica de ferro de Ypanema, I, 280-284.

KIEPERT, H.: จ. SCHULTZ.

KITTO, THOS. COLLINGWOOD: The Brasilian gold mines. The Mining Journal, LVI, 206. London, Feb. 20, 1886.

KITTO, THOS. CoLIINGWOOD: The Brazilian gold mines. The Mining Journal, LVI, 514. London, May 1, 1886.

KITTO, THOS. COLLINGWOOD: Brazilian gold mining-the St. John del Rey. The Mining Journal, LVII, 768. London, June 18, 1887.

KNEELAND, SAMUEL, Jr.: (The stone reef at Pernambuco.) Proc. Boston Soc. Nat. History, IV, 390-391. Boston, 1854.

KNOD, REINHOLD: Devonische Famen Boliviens. Neues Jahrb. f. Min.. Beilage Band, XXV, 493-600. Stuttgart, 1908.

KOBELI, FRANZ VON: Ueber einige in der Natur vorkommende Verbindungen des Eisenoxyde. (Martit aus Brasilien.) Abhandlungen der mathemat.-physikal. Classe der $K$. Bayerischen Akad. der Wissensch. München, 1832, I, 147-152. Abstract: Neues Jahrbuch für Mineral., 1834. 420. 
KOBELL, V.: Ueber den Hydrargillit von Villa Rica in Brasilien. Gelehrte Anzeigen von Mitgliedern der $K$. bayer, Akudemie der Wisscnschaften, No. 112, XXIV, 899, 902. München, 184T.

KOBELL, F. V.: Ueber den Ilydrargillit von Villa Rica in Brasiliell. Erdmann's Journal für Praktische Chcmie, XLI, 152-154. Leipzig, 1847.

KOBELL, FR. V.: Ueber den Hydrargillit aus Brasilien. Erdmann's Journal für Praltische Chemie, L, 493-496. Leipzig, 1850.

KOBELL, FR. V.: Hydrargillit aus Brasilien. Neues Jahrbuch für Mineralogie, Gcognosie, Geologic und Petrefakten-Kunde, 1852, p. 705. Stuttgart, 1852.

KOELER, JULIO: Estudo technico industrial sobre a carvão de pedrat na('ional das minas do Arroio dos Ratos, Estado do Rio Grande do Sul, Rio

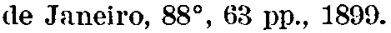

KOELIER, JULIO DELAMARE: O manganez no Brazil. Revista do Instituto Polytechnico Brazileiro. $43^{\circ}$ an. XXXI. Rio de Janeiro, 1906.

KoENIGSWALD, GUSTAVo: Rio Grande do Sul, $8^{\circ}$, 115 pages, São Paulo, 1898, 1 map, 50 ills. in text. Minerals of Rio Grande do Sul, 5-8. Review: Mittheilungen der $K . K$. Geographischen Gesellschaft in Wien, XLII, 190-191. Wien, 1899.

KOETTLITZ, REGINAID: From Para to Manaos; a trip up the Lower Amabon. Scott Geog. Mag., XYII, 11-30. Edinburgh, 1901.

KOHLMANN, H.: Beitrage zur Kentnis des brasilianischen Berylls. Neues Jahrb. $f$. Min., Beilage Band, XXV, 135-181. Stuttgart, Mar., 1908.

KOLLMANN, J.: Hohes Alter der Menschenrassen. Zeitschrift für Ethnologie, 181-212. Berlin, 1884. Schädeln von Lagoa Santa, 194-212. Bibliography, 210-212.

KOSERITZ, CARLOS VON: Sambaquis da Conceição do Arroio. Revista do Inst. Hist., XIVII, parte I, 179-182. Extr. da Gazeta de Porto Alegre. Rio de Janeiro, 1884.

Koseritz, K. VoN: Die Lagoa dos Patos in Südbrasilien. Globus, VI, 347, 1864 .

KOSSMAT, FRANZ: Die Bedeutung der südindischen Kreideformation für die Beurtheilung der geographischen Verhältnisse während der Späteren Kreidezeit. Jahrbuch der $K$. K. Reichsanstalt, 1894, XI.IV, 459-478. Wien, 1895. Brazil, 466-467.

KOSSMAT, FRANZ: Untersuchungen über die südindische Kreideformation. Beiträge $\approx \| l \cdot$ Paleontologie und Ceologie östercich-Ungarns unl des Orients, $4^{\circ}$, IX, 97-203. Wien, 1895. Brazil, 189, XI, 1-46, 89-152. Wien, 1898. Brazil, 11, 21, 24, 28, 139, 145, 146.

KOSTER, HENRY: Reisen in Brasilien. Aus deni Englischen, $x+624$ pp. 2 maps, $8^{\circ}$. Weimar, 1817. Translated from the English edition, q. v.

KOSTER, HENRY: Travels in Brazil, second edition, in two volumes. Tondon. 1817. Map and illus. Vol. I, xii +406 ; II, iv +380 . A few notes on the geology of Pernambuco, Parahyba, Rio Grande do Norte and Ceara.

KOSTER, HENRY: Voyages dans la partie septentrionale du Brèsil dupuis 1809 jusqu' en 1815. comprenant les provinces de Pernambuco, Cenrá. Paraiba, Maragnan, ete. Traduits de l'anglais par M. A. Jay. 8 planches. 2 cartes. 2 vols. in $8^{\circ}$, XLIX, 376 et 512 pages. Paris, 1818.

KOSTER, HENRY: Voyages pittoresques, scientifiques et historiques en Amérique, Brésil, les provinces de Pernambuco, Ceará, Paraiba, Maragnan (etc.) traduits par A. Jay. 2 vols. in $8^{\circ}$, avec carte et figures. Paris, 1846.

KRAATZ-KOSCHLAU, KARL VON und HUBER J.: Zwischen Ocean und Guamá. Beitrag zur Kentniss der Staates Pará. Memorias do Museu Paraense de Historia Natural e Ethnographie, II, 1-34. Pará. 1900. Miteiner Karte 1.10 ' 'afeln, $4^{\circ}$. This article was also published in French; see under $H$ uber. $J$. 
KRASSER, F.: Konstantin von Ettingshausen's Studien uber die fossile Flora von Ouriçanga in Brasilien. Sitzungsberichte der kairerlichen Akademic der Wissenschaften, CXIY, 852-860. Wien, 1903.

KRAUS, E. H., and REITINGER, J.: Hussakit ein neues Mineral und dessen Beziehung zum Xenotim, Zeitschrift für Mineralogie und Krystallographie, XXXIV, 268-277, 1901. Abstract: School of Mines Quarterly, XXIII, 299. New York, April, 1902. Abstract: Mining Magazine, XIII, 307-308. London, 1903. Hussakite, a new mineral and its relation to Xenotime. Amer. Geologist, XXX, 46-55. Minneapolis, July, 1902. Abstract: Transactions of the Institute of Mining Engineers, XXII, 723. Newcastle-upon-Tyne, 1903.

KROCKOW, C. VON: Ein brasllianischer Vulean. Das Ausland, XXXIX, No. 12, 287-288. Augsburg, 20 März, 1866.

KRONE, RICARDO: As grutas calcareas de Iporanga. Revista do Museu Paulista, III, 477-500, S. Paulo, 1898.

KRUG, EDMUNDO: The Apiahy gold deposits. Brazilian Mining Revieu, I, 174-175. Rio de Janeiro, Feb., 1904.

KUNZ, G. F.: Five Brazilian diamonds. Science, III, 649-650. Cambridge, May 30, 1884. Abstract: Zeitschrift für Krystallog. und Mineralogie, XI, 448. Leipzig, 1886.

KUNZ, GEO. F.: Gems and stones; the diamond; Brazilian mines. Engineering and Mining Journal, XLIV, 366. New York, Nov. 19, 1887.

KUNZ, GEORGE F.: (Diamonds in) Brazil. Twenty-first annual report of the U. S. Geological Survey, Part VI, continued pp. 425-431. Washington, 1901.

KUNZ, GEORGE F.: The production of precious stones in 1900. Extract from Mineral Resources of the United States for $1900.8^{\circ}$. Washington, 1901. Brazilian diamonds, pp. 14-15. Abstract: The Geological Record for 1878, 282. London, 1882.

KUNZ, GEORGE F.: (Diamonds in Brazil.) Mineral Resources of the $U$. S. for 1902, 17-24. Washington, 1903. Abstract: National Geographic Magazine, XIV, 451-458. Wasfington, Dec., 1903.

KUNZ, G. F.: Precious stones (in the U. S.). Mineral Resources of the U. S. for 1904. Washington, 1905. Precious stones from Brazil, 943-949.

KYLE, J. J.: On the composition of the rivers Uruguay and Parana. Chemical News, XXXVIII, 28. London, 1878.

Notes the high percentage of silica, and suggests that the Uruguay silicated waters explain the origin of the agates of South America.

KYLE, JUAN J. J.: La composición quimica de las aguas de la Republica Argentina. Anales de la Sociedad Cientifica Argentina, XLIII, 19-25. Buenos Aires, 1897. Analyses of waters of Rios Uruguay and Paraná.

IACERDA, A. DE: Documents pour servir a l'histoire de l'homme fossile du Brěsil. Men. Soc. Anthropologique, II, 517. Paris, 1882.

LACERDA, AUGUSTO DE ABREU: Relatorio da Commissão geographica e geologica do Estado de Minas Geraes. Annexo 3 do Relatorio apresentado ao Dr. Presidente do Estado de Minas Geraes pelo Secretario de Estado dos Negocios dả Agricultura, Commercio e Obras Publicas, Dr. Francisco Sá em o anmo de 1895 . II. Annexo 3, pp. 1-35e Sub-annexo A, B, C. D. E, F (Topographia, ete.). $4^{\circ}$. Ouro Preto, 1895.

LACERDA, AUGUSTO FREDERICO DE: The gold mines of Rio de Contas in Bahia. Brazilian Mining Reviev, I, 250-251. Rio de Janeiro, July, 1904.

LACERDA FILHO, JOÃO BAPTISTA DE: O homem fossil da Lagôa Santa. Revista Brazileira, VII, 285. Rio de Janeiro, 1881.

LACORDAIRE, TH.: L'or des Pinheiros. Revue des Deux Mondes, 1835, 4me sêrie, II, 3355-353. Paris, 1835.

I.ACROIX, AL.: Contributions à l'êtude des gneiss a pyroxène et des roches a wernerite: Gneiss a pyroxène et wernérite du Brésil. Bull. Soc. Française de Minéral., XII, 350. Paris, 1889. 
LACROIX, A.: V. LEVY, M.

LAERNE, C. F. VAN DELDEN: Brazil and Java. Report on coffee culture in America, Asia and Africa, to H. E. the Minister of the Colonies. London, 1885. Geology and physical geography after Derby, 12-26. Geologic map of the coffee regions at the end.

LAERNE, C. F. VAN DELDEN: Le Brêsil et Java. Rapport sur la culture du Café en Amerique, Asie et Afrique. La Haye, 1885. (Geology and physical geography mostly quoted from Derby in Wappäus, 12-24.) (Has geological map after Derby, dated 1884.)

rALLEMANT, ROBERT: Ueber einige gleichlautende Bezeichnungen verschiedener Oertlichkeiten in der Brasilianischen Geographle. Zeitschrift für Allgemeine Erkınde, N. F., XV, 153-158. Berlin, 1863.

LAMPADIUS, W. A.: See Johnson, P. N.

LAMPADIUS, W. A., und PLATTNER, G. P.: Ueber das gemeinschaftliche Vorkommen des Platinerzes und des gediegen Sllbergoldes in elnem Gangfossile aus Brasilien. Jour, $f$. technisch. u. ockonomisch. Chemie, XVIII, $353,1833$.

I' (AMOUREAX), A. J.: The secca in Ceara. Evening Post, New York, Sept. 25, 1878. Physical features of northeast Brazil.

LANDSBERG: Ueber die Goldlagerstätten in Brasillen. Verhandlungen des Naturhistorischen Vereines der preussichen Reinlande, Westfalens und des Regierungs Bezirks Osnabrïck, 5e série, 3e année, p. 63. Correspondenzblatt, Bonn, 1886.

LANGE, HENRI: Contributions a la cartographie de la Province Brésilienne de Santa Catharina. Bull. Soc. Géogr., Novembre, 1879, 430-437. Geographic position, map, $8^{\circ}$. Paris, 1879.

LANGE, HENRY: Eine Fahrt nach den Steinkohlengruben von São Jeronymo. Deutsche Rundschau für Geographie, V, 512, 1883.

LANGE, HENRY: Süddbrasilien. Die Provinzen São Pedro do Rio Grande do Sul, Santa Catharina und Paraná mit Rücksicht auf die Deutsche Kolon!sation. Leipzig, 1885. Mineralien, 9, 45, 125-127, 183.

LANGE, HENRY: Die Flusgebiete des Rio Turbarão und des Rio Ararangua. Petermann's Mittheilungen, XXXIV, 10-13, 1 Karte. Gotha, 1888.

LANGE, HENRY: Die Küste des Atlantischen Ozeans von der Barre do Araguary bis zum Rio Tijucas. Petermann's Mittheilungen, XXXV, 171172. Gotha, 1889 .

LANGE, HENRY: Aus dem Staate São Paulo, Brasilien. Petermann's Mittheilungen, XXXVII, 12-20. Gotha, 1891. XXXVIII, 273-283, 2 Karten. Gotha, 1892.

LANGGAARD, THEODORO J. H.: O Naturalista Dr. Lund (Peter Wilhelm) sua vida e seus trabalhos. Rio de Janeiro, $1883.8^{\circ}, 40$ pp., with portralt and ills.

LANGHANS, P.: V. IHERING, H. VON.

LANGLET-DUFRESNOY, ME.: Quinze ans au Brésil, ou excursiona a la Dlamantine de Me. Langlet-Dufresnoy, avec preface par $M$. Paul Le Gay, $12 \mathrm{mo}, 18$ pages. Bordeaux, 1861.

IANGSDORF, RITTER GEO. HRN. V.: Bemerk. tiber Brasilien mit Gewlssenhafter. Belehrung für auswandernde Deutsche, $8^{\circ}$. Heldelberg, 1821.

L., M. DE: Extracto de uma carta de M. de I-, com data de $1^{\circ}$ de Julho de 1839. Tournal des Debats.

An article thus credited is quoted, pages 566-572 of Fran. Ig. Ferreira's Diccionario Geographico das MIinas do Brazil. Rlo de Janelro, 1885, q. v. The Journal des Debats has been examined in the Library of Congress at Washington from July 1 to December 31, 1839, and during this period no such letter was published. The letter quoted by Sr. Ferrelra relates to the Gongo Soco mines in Minas Geraes.

IA PEROUSE: See Milet-Mureau. 
LAPPARENT, A. DE: Traité de géologie. 4me. êd. III, 1311. tage albien; Amérique du Sud. $8^{\circ}$. Paris, 1900.

LAPPARENT, ALBERT DE: Leçons de géographie plysique. Paris, 1896. Brazil, 569-572.

LAROUSSE, PIERRE: Grand dictionnaire unirersel du XIXe siécle. Tone 2, Brasil; orographie; constitution géologique; productions minerales, 1232-1234. $4^{\circ}$. . Paris, 1867.

LASAULX, A. VON: Ueber das Vorkonmen von Elaleolith-Syeniten und echten zu diesen gehöringen Elaeolithporphyren aus der Serra d'Itatiaia westlich von Rio de Janeiro in Brasilien. Sitzungsbericht der niederreinischen Gesellschaft. Bonn. 6 Juli, 1885, 231-232.

LASNE, HENRI: Analyse complete du phosphate des lles de Feruando de Noronha (Brésil). L'Engrais. XIV, No. 50, 1189. Paris, 1899.

LASSAIGNE, J. L.: Extraction du Palladium au Brósil. Jour. Chimie Medicale, IX, 614. Paris, (?)

LAUNAY, L. DE: Les diamants du Cap. Paris, 1897. 195-209 treats of the diamond in Brazil.

LAUNAY, L. DE: V. FUCHS, ED.

LAWRENCE, H. I.: Diamonds and carbons in Babia, Brazil. The Mining Journal, LXXII, 413-414. London, March 22, 1902.

LEA, T. S.: The island of Fernando do (sic) Noronha in 1887. Proc. Royul Geogr. Soc., X. 424-435. London, July, 1888.

LEAN, JOHN: Brazilian gold mines and Mr. Collingwood Kitto. The Mining Journal, LVI, 267. London, Mar. 6, 1886.

CECOCQ, EM.: Composition chimique de quelques terres du Brésil. $L ' I n$ génieur Agricole de Gembloux, te liviaison, 1er Norembre, 1898.

LEDE, C. VAN: v. VAN LEDE, C.

LEONHARD, K. C. R. VON: Mineralogisches Taschenbuch für das Jahr., 1818 . Ie Abtheilung. $8^{\circ}$. Frankfurt an Main. 1818. Brazilian Minerals, 227. $245,524,583$.

LEONHARD, K. C. R. v.: In Brasilien entdeckte Masse von Gediegen-Eisen. Leonhard's Mineralogisches Taschenbuch, Frankfurt am Main, 1821, II, 551-556. Comment on Mormay's discovery of the Bendegó meteorite.

LESLEY, J. P.: Man's origin and destiny sketched from the platform of the sciences, in a course of lectures delivered before the Lowell Institute in Boston in ... 1865-6. I'hiladelphia, 1868. On p. 65 are given the results of observations near Rio de Janeiro by Dr. Ildefonso on stalactites and the age of man.

LEUZE, AIFRED: Pseudomorphosen von Rotheisen nach Pyrit von Antonfo Pereira. Bericht ïber die XXXIV Versammlung des Oberrh. Geol. Vereins. 1891. 28-31. Stuttgart, 1891. Abstract: Zeitschuift für Krystallogr'tphie und ILineralogie. (Groth) XXII, 294. Leipzig, 1894.

T.EUZE, ALFRED: Ueber optisch interessante Mineralien von Brasilien, sowie iber neue Funde an Rosenegg. Bericht iber die 31. Versammlung des Oberrheinischen Geologischen Vereins zu Tuttingen am 14 April, 1898 Topase 11. Turmaline, 21-2 . $8^{\circ}$. Stuttgart, 1898.

LEVASSEUR, E.: Le Brésil par F. Levasseur *** avec la collaboration de M. de Rio Branco. Eduardo Prado, d’Ourem. Henri Gorceix, etc. (Extrait de la Grande Encyclopédie.) Deuxiême édition. Publiê par le Syndicat Franco-Brésilien pour l'Exposition Universelle de Paris en 1889. Paris, 1880. $4^{\circ} .105+$ viii pp. Géographie plyssique, par M. E. Ievassenr. 1-7. Géologie jar M. Henri Gorceix, $7-8$; les explorntions scientifiques, par M. le baron de Rio Bramco, 24-25.

LEVAT, E. D.: Les placers aurifères du contesté franco-bresilien. Revue Scientifique, 7-15. Paris, 2 Juillet, 1898. 
IREVAT, E. D.: Guide pratique pour la recherche et l'exploitation de l'or ell Guyane Francaise. Rapport A. M. le Ministre de l'Instruction Publique sur l'exploitation de l'or en Guyane. Annales des Mines, 9e série, Xill, 386-616, maps. Paris, 1898. Contains bibliography, 607-608.

LEVY, MICHEL, et LACROIX, A.: Réfringence et biréfriugence de quelques mineraux des roches. Comptes Rendus de l'Acad. des Sciences, CVI, 777-779. Paris, 1888. Abstract, Neues Jahrb. f. Mineral., 1889, II, 32-33, Referate.

IIAIS, EMMANUEL: Inclinaison des couches de roches arénacées modernes des côtes du Brésil. Extrait d'une lettre à Elie de Beaumont. Comptes Rendus de l'Academie Sci., L, 762-763. Paris, 1860.

IIAIS, E.: 'Travaux géographiques effectués au Brésil. Lettre au Secrétaire gênéral. Bul. Soc. Géogr. 6ine série, XVII, 275-277. Paris, 1879.

IIAIS, EMMANUEL: L'espace céleste et la nature tropicale; description physique de l'universe d'après des obselvations persomnelles faites dans les deux hémisphères. Preface de M. Babinet. Dessins de Yan Dargent. $8^{\circ}$. Paris, s. d.

IIAIS, EMM.: Memoria sobre o melhoramento do porto da cidade do Recife, na provincia de Pernambuco. Revista Brazileira IV, no. 11, 183-218. Rio de Janeíro, 1861. Contains some notes on the geology of Pernambuco.

LIAIS, EMM.: Algumas notas sobre os materials que se deve empregar nos trabalhos de melhoramento do porto da cidade de Recife. Revista Brazileira, IV, 219-222. Rio de Janeiro, 1861.

LIAIS: Atlas du haut San Francisco. Comp. Rend. de l'Acad. des Sci., LX, 1200-1291. Paris, 1865. Noticie, Petermaln's Mlittheilungen, 1866, 412-414.

LIAIS, EMMANUEL: Cartes gravées de l'atlas du haut San-Francisco, Brésil. Lettre à Elfe de Beaumont. Comptes Rendus de l'Acad. sci., LX, 849-851. Paris, 1865.

LIAIS, EMM.: Explorations scientifiques au Brésil. Hydrographie du haut San Francisco et du Rio das Velhas, ou résultats au point de vue lyydrographique d'un voyage effectué dans la Prov. de Minas Geraes. Ouvrage publié par ordre du gouvernement impérial du Brésil et accompagné de cartes levées par l'auteur avec la collabolation de MM. Eduardo José de Moraes et Ladisláo de Souza Mello Netto. Paris, 1865, in-fol. 26 pp. et planches.

Physical features. The hills and mountains are laid down on right lines to agree with the theory of E. de Beaumont in his Systeme des Montagnes.

LIAIS, E.: Die Aufnahme des oberen San Francisco und des Rio das Velhas in Brasilian. Petermann's Mittheilungen, 1866, 412-414. 1 map. Gotha. 1866.

IIAIS, EMMANUEL: Rxplorations scientifiques au Br'ésil. 'Traité d'astronomie appliquée et de géodésie pratique comprenant l'exposê des mêthodes suivis dans l'exploration du Rio San Francisco et précédé d'un rapport au gouvernement impérial du Brésil. $8^{\circ}$. Paris, 1867.

LIAIS, EMMANUEL: Climats, géologic, faume et géographie botanique du Brésil. $8^{\circ}$. VIII +640 pages et 1 carte. Paris, 1872. Review and extracts under the title "Gêologie et histoire naturelle du Brêsil d'après les observations de M. Emmanuel Tiais." Archives des Sciences Physiques et Naturelles. XIVII, 312-324. Genéve. 1873. Extrait par M. Gorceix, Revue de Géologie. por les années 1873-1874. XII, 185-188. Paris, $187 \theta$.

LIMA, JOS DE ABREU E.: Apontamentos sobre a Ilha de Fernando de Noronha em 1857. Revista do Inst. Arch. e Geog. Pernambucano. No. 38 Pernambuco. 1890. Aspecto da ilha com notas sobre a geologia, 7-9.

IISBOA, ALFREDO: Memoria descriptiva e justifieativa do projecto de melhoramento do Porto do Recife. Pernambuco. 1887. Notes on the stone reef of Pernambuco. 6-8; quotes Hartt. 98-100.

LISBOA, JOAQUIM MIGUEL RIBEIRO: Explorañ̃o do Furo de Tupinambaranas, do Ramos e rios Sacnrà e Atrennan. Annexo (letra D) ao Rela. torio do Ministro de Agricnltura, etc. Rio de Janeiro, 1870, I-33. 
IISBOA, MIGUEL RIBEIRo: Les manganêses du Brésil. Revue Universelle des Mines, 42e annee, 3me série, XLIV, 4e 'Trimestre, 1-22. Paris, Liége, 1898. Abstract: Iron and Steel Institute, LV, 293-294. London, 1899.

IISBOA, M. ARROJADO RIBEIRO: O manganez no Brazil. Separate, 48 pp. Rio de Janeiro, 1898. Jornal do Commercio do Rio de Janeiro, 19 de Junbo de 1898.

LISBOA, M. ARROJADO RIBEIRO: Ueber die Manganerzgruben in Minas Geraes, Brasilien. Jornal do Commercio, Juin u. März, 1899. Review by E. Hussak, Zeitschrift für praktische Geologie, Juli, 1899, 256-257. Berlin, 1899.

IISBOA, ARROJADO RIBEIRO: Le manganèse au Brésil. Annales der Mines, $9 e$ série, Mémoires XV, 115-123. $8^{\circ}$. Paris, 1899.

LISBOA, ARROJADO: Industria do ferro em Minas Geraes e seus impostos absurdos. Jornal do Commercio. Rio de Janeiro, 4e 5 de Maio, 1902. Translated: The over-taxation of the iron export trade of Minas. Brazilian Mining Reviewo. I, 55-59. Rio de Janeiro, Aug. 1902.

IISBOA, MIGUEL ARROJADO RIBEIRO: Um caso de critica scientifica. Artigos publicados no Commercio de São Paulo. São Paulo 17 a 25 de Junho, 1902 . Separate $8^{\circ}, 65$ pages.

IISBOA, ARROJADO: As areias monaziticas. Jornal do Commercio, Rlo de Janeiro, 5 de Jan. de 1903. Annaes da Escola de Minas No. 6, 105-132. Ouro Preto, 1903.

IISBOA, M. A. R.: Occorrencia de seixos facetados no planalto central Brasileiro. Annaes da Escola de Minas de Ouro Preto, No. 8, 23-74. Ouro Preto, 1906.

LISBOA, M. A. R.: Bibliographia mineral e geologica do Brazil, 1903-1906. Annaes da Escola de Minas de Ouro Preto, No. 8, 199-219. Ouro Preto, 1906.

LISBOA, MIGUEL A. R.: Report on the manganese ore deposits of Morro da Mina, Lafayette Queluz, Minas Geraes, Blazil. Brazilian Engineering and Mining Review, III, 83-88, 97-111. Rio, June and July, 1906.

LISBOA, M. A. R.: See HUSSAK.

LISBOA, MIGUEL A. R.: The occurrence of facetted pebbles on the central plateau of Brazil. Amer. Journal of Science, XXIII, 9-19. Jan., 1907.

LISBON MERCHANT: See ANONYMOUS.

IISLE, DE: v. De l'Isle.

LOFGREN, ALBERTo: Os sambaquis de S. Paulo. Boletim da Commissão Geogr. e Geologica do Estado de S. Paulo, No. $991 \mathrm{pp}$. and plates. $\mathbf{8}^{\circ}$. S. Paulo, 1898.

LöFGREN, A.: Os sambaquis. Revista do Instituto Historico e Geogr. de S, Paulo, VIII, 458-465. S. Paulo, 1903.

IOMBARD, I.: Analyse No. 4. Calcareo dolomitico do Betume, punto a Serra do Lenheiro em 8, S. Joño d'el Rey. Devista Industrial de Minas Geraes, Anno I, No. 9, 15 de Junho de 1894, 232. Ouro Preto, 1894.

LOMBARD, LOUIS: Note sur les exploitations des mines d'or anciennes aux environs de S. João d'el-Rey, 'Tiradentes et Prados. Revista Industrial de Minas Geraes, Anno I, N. 6, 133-135. Ouro Preto, 15 de Março, 1894.

TOMBARD, LOUIS: A minelação nos municipios de S. João d'El-Rey, 'Tirndentes e Prados 110 Estado de Minas Geraes. Revista Industrial de Minas Geraes. Anno I, No. 10, 243-246. Ouro Petro, 15 de Julho, 1894.

Mineraç̃̃o da Serra de S. José. Revista Industrial de Minas Geraes, Anno II, No. 11, 271-275. Ouro Preto, 15 de Agosto, 1894.

IOMBARD, I.: Relatorio sobre a exploração da parte sul do Estado de Pernambuco entre Palmares e Bom Conselho. Relatorio apresentado ao Exm. Sr. Governador do Estado Dr. Alexandre Jose Barbosa Lima pelo Dr. Rodolpho Galvão, Secretario dos Negocios da Industria. $8^{\circ}$. Reclfe, 1895. Relatorio de Lombard 51-62 e cartas. 
LOMBARD, L.: Relatorio apresentado ao Exm. Sr. Governador do Estado, etc. Pelo Dr. Rodolpho Galvão, Sec. dos Negocios da Industria, Recife, 1895. Annexos contain: Projecto de organisacão da carta geographica e geologica do Estado de Pernambuco, $105-122$ (an. rep.) Relatorio sobre a exploração mineralogica de Garanhuns a Buique e da zona salitrosa de Buique 123-141. $8^{\circ}$, with 2 maps. Also in Revista Industrial de Minas Geraes, Anno IV, No. 24, 310-313, 10 de Maio 1897. V, No. 25, 6-8, 20 de Junho de 1897. Ouro Preto, 1897.

LOMONOSOFF, M.: Note sur le gisement des diamants au Brésil. Annales de Chimie et de Physique, 3e sêrie, VII, 241-243. Paris, 1843. Annales dès mines, 4e série, III, Paris, 1843. Abstract: Jahresbericht über die Fortschritte der Chemie und Mineralogie von Jacob Berzelius, XXIV, 295-296. Tübingen, 1845.

IOPES, ANTONIO SIMOES: Relatorio dos experiencias feitas no gazometro de Porto Alegre com o carvão das minas do Arroio do Ratos pelo Director Fngenheiro da Companhia Rio Grande de Illuminação a Gaz. $8^{\circ}$. Pelotas, 1899.

LORIOL, P. DE: [Description of a new genus and species of Cidaridæe from Pernambuco.] Contribuições á paleontologia do Brazil. Por Charles A. White, Archivos do Museu Nacional do Rio de Janeiro, VII, 254-256. Rio de Janeiro, 1887.

LOUIS, H.: v. PHILLIPS, A. J., and.

LOWE, M. F.: $\nabla$. SMYTH, W.

IUCCOCK, JOHN: Notes on Rio de Janeiro, and the southern parts of 15 iazil; taken during a residence of ten years in that country, from 1808 to 1818 . London. Printed for Samuel Leigh in tle Strand, 1820. $4^{\circ}$, maps, xvi + . 639 panges. Notes on the geology chaps. XIII, XIV, and XV on Minas Geraes.

IUCCOCK, J.: Bemerkungen über Rio de Janeiro und Brasilien, wälrend e. Aufenthaltes v. 1808-1818. Aus 2 Bde. $8^{\circ}$. Weimar, 1821. Translation of the preceding work.

LUDWIG, E., und TSHERMACK, D.: Der Meteorit von Angra dos Reis. Minevalogische und P'etrographische Mittheilungen, von G. Tschermak, N. I'. VIII, 341-355. Vienna, 1887. Abstract: Zeitschrift für Krystallog. un $l$ MIineralog., XVII, 206-208. Leipzig, 1890.

IUNAY: Sur le fer nickele de Sainte-Catharine. Extrait d'une lettre atdressée a M. Daubrée. Comptes Rendus de l'Acad. Sci. LXXXV, 84-85. Paris, 1877. Abstract: The Geological Recorl for 1877, 220. Iondon, 1880.

IUND, HENRIETTE: Naturforskeren Peter Wilhelm Lund. En biografisls Skizze af Henriette Lund, med to Belleder. Kjöbenhavn, 1885. $\mathbf{8}^{\circ}, 123$ pages. (Portrait and view of Lunđ's house at Lagôa Santa.)

LUND, P. W.: Om Huler i Kalksteen i det indre af Brasilien, der tildeels indeholde Fossile Knokler. Det Kongelige Danske Videnskabernes Selslabs Naturvidenskabelige og Mathematiske Afhandlinger. VI, p. CXI, Förste Afhangling, 207-248. Anden Afhandling. Lapa da Cerca Grande; CXII, 307-332, Plates, $4^{\circ}$. Kjöbenhavn, 1837.

LUND, P. W.: Om Huler i Kalksteen, i det indre af Brasilien, der tildeels indeholde Fossile Knolsler. (On the caves in limestone in the interior of Brazil, some of which contain fossil bones.) Det Kongelige Dansice Vid. Selsk. Natur. og Math. Afhandlinger. (Royal Danish Society of Sciences. Natural History and Mathematical Section.) VI, Förste Afhandling, CXI, 207-248; 2 parts in 1 rol. $4^{\circ}$. Kjöbenhavn. 1836.

IUND, P. W.: Over Kalksteen-hulerne i Brasilien. (On the limestone eares in Brazil.) Oversigt over det Kong. Danske Vid. Selsk. Natur. og Math. 1835-1836. Afl. Vr, 12-15; 207-248; 307-332. Kjöhenhavn. 1837. Portuguere version in the Ammacs da Fscola de Minas Geracs de Ouro Preto no. $4,9-28,1885$. 
IUND, PEDRO W.: Cavernas existentes no calcareo do interior do Brazil, contendo algumas dellas ossadas fosseis. 1a memoria, Copenhague, 1836. (Traducção do Sr. Leonidas Damazio Botelho.) Annaes da Fscola de Minas de Ouro Preto, No. 3, 61-92. Rio de Janeiro, 1884.

IUUND, PETER WILHELM: Blik paa Brasiliens Dyreverden för sidste Jordomvæltning. Förste Afhandling: Indledning, Lagôa Santa. D. 14 de Febr., 1837. (Særskilt Aftryk af det Klg. Danske Videnskabernes Selslcabs naturvidenslcabelige og Mathematislie Afhandlinger. 8 Deel. 27296.) (Afh. 2, 3, og 4 [Pattedyrene] Kjöbenhavn. Særskilt Aftrykt af det Klg. Danske Vid. Selskabs Natur. og Math. Afhandlinger. 8 Deel., $1841,61-144 ; 217-272 ; 273-296 ; 9$ Deel., 1840, 1841, 1-16 + 172 + 1-3.) of the animal world of Brazil before the last revolution. Flrst part, introduction. Lagôa Santa. Contributions 2, 3, and 4 the vertebrates. (Also Separate reprint of the Royal Danish Scientific Society. Copenhagen, 1841. English translation, Mag. Nat. Hist. IV, 184 pp. ; 1-8; 49-57; 105-112; 153-161; 207-213; 251-259; 307-317; 373-389.) Femte Afhandling. Fortsættelse af Pattedyrene. Om de Nulevende og Uddöde arter af Roydyrenes familie. (The fifth part. Continuation of vertebrates. On the existing and extinct members of the family of Carnivores. 11th part.) Lagóa Santa, D. 4 de October, 1841. Kongl. Danske Vidensk. Selskabs. natur. og Math. Athandlinger. 11 Deel. 1-82. Kjöbenhavn, 1843. (Also separate, $82 \mathrm{pp}$. Copenhagen, 1843.)

LUND, DR.: (Afhandling over Kalksteenshulerne 1 det Indre af Brasilien.) Oversigt over Kongel. Danske Vid. Selskabs, ete. 1836-1837, 10-12. Kjöbenhavn, 1837 or 1838.

LUND, DR.: (Blik paa Brasiliens Dyreverden för den sidste Jordomvæltning.) Oversigt over Kongl. Danske Vid. Selskabs, etc. 1838, 7-15. KJöbenharn, 1838 or 1839.

IUND: Nouvelles observations sur la faune fossile du Brésil, extraites d'une lettre adressée aux rédacteurs. Annales des Sciences Naturelles, 2me série, XII, Zoologie, 205-209. $8^{\circ}$. Paris, 1839. Abstract: Neues Jahrbuch für Mineral., 1840, 740-741.

IUND: Coup-d'œil sur les espèces eteintes de mammifères du Brésil ; extralt de quelques mémoires présentées à l'Académie royale des Sciences de Copenhague. Annales des Sciences Naturelles, $2 \mathrm{me}$ série, XI, Zoologie, 214-234. $8^{\circ}$. Paris, 1839. Ann. Nat. Hist., III, 135-236, 1839. Abstract: Neues Jahrbuch für Mineral., 1840, 120-125.

LUND: Extract d'une lettre de M. Lund, écrite de Lagôa Santa (Brésil) le 5 Novembre, 1838, et donnant un apercu des espèces de mammifères fossiles qu'il a déconvertes au Brésil. Comptes Rendus de l'Acad. VIII, 570-577. Paris, 1839. Annals of Natural History or Magazine of Zoology, etc., vol. III, 235-236. London, 1839.

LUND, P. W.: Meddelelser over Brasiliens Pattedyrenes. Report upon the vertebrates of Brazil. Oversigt Kongl. Dansk. Videnskab. Selsk., etc., 1839, 19-23. Kjöbenhavn, 1839.

LUND, DR.: List of fossil manmifera from the basin of the Rio das Velhas with an extract of some of their distinguishing characters. Annals of Natural History or Magazine of Zoology, Botany and Geology. III, 422427. London, 1839.

IUND, PETER WILHELM: Blik paa Brasillens Dyreverden för sidste Jordomvæltning. (Mammalia fossil. Brasiliæ.) 4 Afhdlgn. nebst 2 Nachträgen. Mit 39 meist color. Taf. folio Kjöbenhavn. C. 1840 . Four papers by Lund bound in a single volume with the title "Blik paa Brasilfens Dvreverden för sidste Jordomvæltning," containing those from vols. VIII, IX, XI of the Afhandling. Roy. Dan. Soc., and the one in Kröyer's Tidskrift.

IJUND: Nouvelle recherches sur la faune fossile du Bresil. Annales des Science. Nat., XIII, 310-319, Paris, 1840, This list is also given in P. 
Claussen's "Notes géologique sur la province de Minas Geraes" In Bull. de l'Acad. Roy. de Bruxelles. VIII, No. 5, 1841. Abstract: Neues Jahrbuch für Mineral., 1841, 492-497. Stuttgart, 1841.

IUND, P. W.: View of the fauna of Brazil previous to the last geological revolution. ('Translation of Blik paa, etc., by W. Bilton.) Mag. Nat. Hist. (N. S.) IV, 1-8, 49-57; 105-112;153-161;207-213; 251-259; 307-317; 373-389. London, 1840.

LUND, W.: Nye fossile Slaegter af Brltedyrenes og Dovendyrenes Familier. (New fossil genera of the Armadillo and sloth families.) Natuhistorisk Tidskrift Udgivet af Henrik Kröyer, III, 583-588. Kjöbenhavn, 1840-1841.

LUND, P. W.: Fortsatte Bemærkninger over Brasiliens uddöde Dyrskabning. (Further remarks upon the extinct animals of Brazil.) Af Dr. P. W. Lund, Lagôa Santa, D. 27 de Marts, 1840, Kongl. Danske Vidensk. Selsk. Natur. og Math. Afhandlinger. 9 Deel, 121-208, 361-364. Kjöbenhavn, 1842. Separate, 72 pages. Copenhagen, 1842.

LUND, P. W.: Blik paa Brasiliens Dyreverden för den sidste Jordomvæltning. Naturhistorisk Tids7rift Udgivet af Henril Kröyer, III, 85-95, $\mathbf{8}^{\circ}$. KJöbenhavn, 1840-1841. Abstract of the longer paper of the same name.

IUND, P. W.: Iunds seneste Beretninger fra Brasilien. Naturhistorisk Tidskrift Udgivet af Henrik Kröyer, III, 214-220, 8. Kjöbenhavn, 1840-1841. (Abstract of paper in Oversigt over Via. Selskabs Forhandlinger, ete. Aaret, 1839.)

IUND, P. W.: Fortsatte beinarlkninger over Braslliens uddöde Dyrarter. Oversigt over Kongl. Danske Vid. Selskabs, etc., 184, 7-10. Kjöbenhavn, 1840 or 1844.

IUND, P. W.: Blid paa Brasiliens Dyreverden för sidste Jordomvæltning. Det Kongelige Danske Vit: Selskabs Natmvidenskabelige og Mathematiske Afhandlinger. 8 Deel. (Ser. 4). Fölste Afhandling: Indledning, 27-60. Anden Afhandling: Pattedyrene, 61-144. Tredie Afhandling: Fortsrettelse af Pattedyrene, 217-272. Tillagg til de to sidste Afhandlinger, 273-296, $4^{\circ}$. Kjöbenhavn, 1841.

IUND, P.: Versteinerte Knochen voll Menschen und Angestorbenen Thlert!n durch einander in Brasilien. Newes Jahrbuch für Mineral., Geal., etc., 1841, 502, 606. Stuttgart, 1841.

IUND, P. W.: Fortsatte bemarkniuger over Brasiliens uddöde Pattedyrsscabning. Oversigt over det Kongelige Danske Videnskabernes Selskabs Forhandlinger $o g$ dets medlemmers Arbeider $i$ Aaret, 1841, 16-18. Kjöben. havn, 1841.

IUND: (Carte a la Sociêté des Antiquaires de Copenhague sur l'homme fossile.) Abstract: L'Institut, IX, 336. Paris, 8 Juillet, 1841.

IUND: Fortgesetzte Bemerkungen iiber Brasiliens ausgestorbene SäugthierSchopfung nebst einer vorläufigen Ubersicht über die fossilen Reste der Vogel-Klasse. Oversigt over det kongl. Danske Videnskabernes Sels7abs Forhandlinger $i$ saret. Kjöbenhavn, 1841. Miinchner Gelehrten-Anzeigen. 1842, 868-871. Abstract: Neues Jahrbuch fïr Mineral., 1843, 236-337.

IUND, P. W.: Blik paa Brasiliens Dyreverden för sidste Jordomvæltning. Det Kongelige Danske Videnskabernes Selskabs Naturvidenstabelige og Mathematiske Afhanglinger. 9 Deel. Fjerde Afhandling: Fortsættelse af Pattedyrene, 137-208. 'rillæg til Dr. J. (sic) W. Lunds Blik paa Brasillens Dyreverden för sidste Jordomvæltning. Fjerde Afhandling, 361-363, $4^{\circ}$. Kjöbenhavn, 1842.

IUND, P. W.: (Notices of papers presented to the "Kongelige Danske Vid. Selsk.") Det Kongelige Danske Videnskabernes Selskabs Naturvidensliabelige og Mathematiske Afhanglinger, 9 Deel, XXV-XXVII, LXI-LXIIT. Kföhenhavn. 1842.

IUND, P.: Carta escripta da Iagôa Santa (Minas Geraes). ao Sr. 1 Secretario do Instituto. 12 de Janeiro de 1842. Revista do Instituto Historico, IV. 2a ediçáo, 80-87. 'Rio de Janeiro (2nd ed, 1863 for), 1842. 
IUND, P. W.: On the occurrence of fossil human bones of the pre-historical world. Extract from a letter. American Journal of Science, XLIV, 277280. New Haven, 1843. Edinburg New Phil. Jour., XXXVI, 38-42, 1844. Neue Notizen aus dem Gebiete der Natur u. Heilkunde (Froriep). XXIX cols., 147-149. Weimar, 1844.

IUND, P. W.: (Om Brasiliens Rovdyre i nuværende og forrige Jordperiode.) (On the Carboniferous animals of Brazil in the present and last geologic epoch.) Oversigt over det Kongl. Danske Videnskabernes Selskabs Forhandlinger og dets Medlemmers Arbeider $i$ Aaret, 1843, 77-82. Kjöbenhavn, 1844.

LUND, DR.: (Notice of paper presented to the "Kongelige Danske Vid. Selsk.") Det Kongelige Danske Videnskabernes Selskabs Naturvid. og Math. Afhandlinger. 10 Deel, pp. LXXII-LXXVI. Kjöbenhavn, 1843. 11 Deel, pp. LXXXII-LXXXVI. · Kjöbenhavn, 1845.

IUND, P. W.: (Fortsatte Efterretninger om haus videnskabelige Arbeider 1 Brasilien.) Oversigt over det Kongl. Danske Vid. Selskabs Forhandlinger, etc., Aaret, 1843, 79-83, $8^{\circ}$. Kjöbenhavn, 1844.

I.UND, P. W.: Blik paa Brasiliens Dyreverden för sidste Jordomvæltning. Det Kongelige Danske Videnskabernes Selskabs Naturvid. og Math. Afhandlinger. 11 Deel, Femte Afhandling: Fortsættelse af Pattedyrene. Om de nulevende og uddöde Arter af rovdyrenes famllie paa det tropiske Brasiliens indre Höisletter. Förste Afhanglin: Hundegruppen, 1-82, $4^{\bullet}$. Kjöbenhavn, 1845.

IUND, P. W.: Ueber das Alter der Americanischen Menchenrace und ueber deren Angeblichen Zusammenhang mit den Racen der sogen. alten Welt. Neue Notizen aus dem Gebiete der Natur. und Halkunde (Froriep), XXXV col., 161-163. Weimar, 1845.

IUND: Sur 1-antiqueté de la race Américaine [etc.] (Extrait d'une lettre adressee a M. Rafn.) Comptes Rendus de l'Acad. des Sci., XX, 1868-1870. Parls, 1845.

LUND, P. W.: Notice sur des ossements humains fossiles, trouvés dans une caverne du Brésil. Extrait d'une lettre a M. C. C. Rafn, Secrétaire de la Sociêté. Dated Lagôa Santa le 28 Mars, 1844. Kongelige Nordiske Oldskrift Selskab: Mémoires de la Soc. Royale des Antiquaires du Nord, 1845-1847, 49-77. Copenhague, au Secrétairiat de la Société, 1847.

IUND: Geology of Brazil. Amer. Journal Sci., 1846, II, 308. Results quoted from L'Institut, 1844, No. 621, 412.

LUND, P. V.: (Efterretninger om haus nyeste Huleundersögelser og Opdagelser 1 Brasilien.) Oversigt over Kongl. Danske Vid. Selskabs, etc., 1845, 1亏े, 57-64. Kjögenhavn, 1846.

IUND, P. W.: Meddelelse af det Udbytte de i 1844 undersögte Knoglehuler have afgivet til Kundskaber om Brasiliens Dyreverden för sidste Jordomvæltning. (Report upon the results which the bone caves of Brazil examined in 1844 bave yielded to the knowledge of the animal world of Brazil before the last revolution.) Kjöbenhavn Danske Vid. Selsk. Afh., XII, 57-94, 1846. I et Brev. Særskilt Aftryk af det Kongl. Danske Videnskabernes Selskabs Naturvidenskabelige og Mathematiske Afhandlinger. Kjöbenhavn, 1845. Also separate of 36 pages.

LUND, P. W.: Efterretning om haus nyeste Huleundersögelser og opdagelser 1 Brasilien. (Report on the last cave examinations and discoveries in Brazil.) Oversigt over Kongl. Danske Vid. Selsk. Afha., XII, pp. LXVLXXI. Kjöbenhavn, 1846.

IUND, P. W.: (Objects d'antiquité brésilienne envoyés a la Sociêté Royale des Antiquaires du Nord.) Mémoires de la Soc. Roy. des Antiquaires du Nord, 1845-47, pp. 105-106. Copenhague, 1847.

IUND, P. W.: Rettelser til Afhandlinger om Braziliens Forverden. Det Kongelige Danslee Videnskabernes Selskabs skrifter. Ser. V. Naturvid. og Math. Afdeling. Förste Bd., 353-354. Kjöbenhavn, 1849. 
LUND, P.: Carta escripta da Lagôa Santa (Minas Geraes) a 21 de Abril de 1844. Revista do Instituto Historico, VI (2a edição), 334-342. Rio de Janeiro, 1865 (2a edição for 1844).

LUND, P. W.: Grutas calcareas do interior do Brazil contendo ossos fosseis. Annaes da Escola de Minas de Ouro Preto, No. 4, 9-26. Rio de Janeiro, 1885.

IUND: จ. GORCEIX, H.

LUND, P. W.: See Macaire, $J$.

LUND, P. W.: See Strain, J. G.

IUSTOZA, JOAQUIM: Informações sobre o Morro da Mina. Revista to In. stituto Polytechnico Brazileiro, XXXI. Rio de Janeiro, 1906.

LUTKEN, C.: L'exposition de quelques-uns des cranes et des outres ossements humains de Minas Geraes dans le Brêsil central découverts et déterrés par le feu Professor P. W. Lund. Congrés International des Américanistes. Compte Rendu de la Vme session. Copenhague, 1883. 40-48, $8^{\circ}$. Copenhague, 1884.

LƯTKEN, CHR.: Rêsumé des remarques préliminaires de M. Lütínen sur lès ossenents humains des cavernes du Bresil et des collections de M. Luud in $\mathbf{E}$ Museo Lundii. Vol, 1, iv paper, 19-29. Kjöbenlııvı, 1888. (A collection of contributions upon the bones of animals and of men, excavated by Professor Lund in the limestone caves of the interior of Brazil.)

İ̛̀TKEN, CHR. FR.: E Museo Lundii. En Samling af Afhandlinger om de I det indre Brasiliens Kalkstenshuler af Professor Dr. Peter Vilhelm Lund udgravede og iden Lundske palaeontologiske afdeling af Kjöbenhavns Universitets zoologiske Museum opbevarede Dyre- og Menneskeknogler. Kjöbenhavn, 1888-1896, 3 vols. in $4^{\circ}$. See Reinhardt, Winge, Lütken and Hansen. (The pages of these vols. are not numbered consecutively, but the papers are numbered.) (From the Lund Museum. A collection of contributions of the bones of animals and men excavated in the limestone caves of the interior of Brazil by Prof. P. W. Lund. and preserved in the Lund paleontological department of the Zoological Museum of the University of Copenhagen.)

LUTKEN, CHR. FR.: Indledende Bemærkninger om Menneskelevninger 1 Bra. siliens Huler og i de Lundske Samlinger, $E$ Museo Lundii, 1, iv palper, 1-18. Kjöbenhavn, 1888.

IYON, MAX: Description de l'ìtat de Rio Grande do Sul (Brésil). Comptes Renaus de la Soc. Géogr., 1891, 515-525. Paris, 1891. Physical fentures.

MACAIRE, J.: Sur les ossements fossiles trouvés dans les cavernes du Brésil. Bibliotheque Universelle de Genéve. Nouvelle série, $8^{\circ}$, IIV, 182-188. Paris, 1844. (Resume of Lund's Blik paa Brasilein.)

McCORMICK, R.: Voyage of discovery in the Arctic and Antarctic Sens, I, 23 25 on the rocks of Trinidade. London, 1884.

McCORMICK, S. J.: Notes on the treatment of the refractory low grade gold ores at the Ouro Preto Gold mine, Brazil. Trants. of the Institution of Mining and Metallurgy. V, 116-125. London. 1896-1897.

McDANIEL, R. P.: Minerals, mining, etc., of the State of Bahia. Comsular Reports (U. S.), LI, 384-387. Washington, 1896. This article is quoted in the Monthly Bulletin of the Burean of American Repwhlics. III. 613-616. Washington, 1896.

MACEDO, M. A. DE: Observasons (sic) sobre as seccas do Ceara e melos de augmentar o volume das aguas nas correntes do Cariry. $8^{\circ} .104$ pages and map. Geologic notes 51.57 footnote. Stuttgart. Typographia de Em!l Mueller, 1871.

MACEDO, MARCOS ANTONIO DE: Descripcão dos Terrenos Carhoniferous d: Comarca do Crato. Bibliotheca Guanabarense. Trabalhos da Sociedade Vellosiana, 23-28. Dated Crato. 8 de Jan. de 1855. Rio de Janeiro. de 1855. Abstract: Diccionario Geographico das Minas do Brazil J'or Francisco Ignacio Ferreira, 102-104. Rio de Janeiro, 1885. 
MCGREGOR, J. H.: Report on Mosasuarus brasiliensis. Appendix to report of' I. C. White on coal measures of Brazil. (In press, Rio.)

MACHADO, GABRIEI MIIITÃO DE VILTANOVA, G. R. GABAGLIA, outros: (Pareceres sobre minas de mercurio e de carvão na Provincia de Minas.) Auxiliador da Industria Nacional, II, 169-173. Rio de Janeiro, 1864.

MACHADO, JORDANO: Beitrag zur Petrographie der südwestlichen Grenze zwischen Minas Geraes und $\mathbf{S}$. Paulo. Inaugural-Dissertation, vertasst und der hohen philosophischen Facultät der Grossherzoglichen Herzoglichen Gesammt-Universität Jena zur Erlangung der Doctorwürde. $8^{\circ}, 43$ pp., map and plate. Wien, 1887. T'schermak's Mineral und petrog. Mittheil. N. F. 1887, IX, 318-360, 4 plates. Wien, 1888. Abstract.: Neues Jahrbuch für Mineral., 1890, I, 93-94. Referate. Abstract: Mineral Mag. and Jour. Min. Soc., No. 38, 168-169. London, 1889. Abstract: Zeitschrift für Krystallographie und Mineralog., XVII, 304. Leipzig, 1890.

MACK, K.: Pyroelectrische und optische Beobachtungen am brasilianischen 'Topas. Wiedermann's Annalen der Physile und Chemie, N. F., XXVIII, 153-167. Leipzig, 1886. Abstract: Neues Jahrbuch für Mineral., 1888, I, 394-396. Abstract: Zeitschrift für Krystallographie und Mineralogie (Groth), XII, 579-580. Leipzig, 1888.

MACKINTOSH, J. B.: Analysis of titanic iron sand from Brazil. (Sent by John Gordon of Rio de Janeiro.) Amer. Jour. Science, 3rd series, XXIX, 342-343. New Haven, 1885. Austract: Neues Jahrbuch für Mineral., 1887, I, 27-28. (Referate.) Abstract: Bull. Soc. Francaise de Minéral., 1886, IX, p. 90. Abstuact: Zeitschrift für Krystallographie und Mineralogie (Groth), XI, 296. Leipzig, 1886. Abstract: Journal Iron and steel Institute, I, 258. London, 1885.

MACKINTOSH, J. B.: Analyse de area ferro-titanifera do Brnzil. Revista de Engenharia, 28 de Junho de 1885, VII, 138. Extrahido do Am. Jour. Sci., April, 1885, XX்IX, 342-343. Rio de Janeiro, 1885.

MAGALHÃES, COUTO DE: Primeira viagem ao Araguaya. Escripta e publicada em 1863. $8^{\circ}$. São Paulo, 1889. (XXX +150 pp. $)$ Contalns notes on geology and minerals.

MAGALHÃES, COUTO DE: Dezoito mil milhas no interior do Brazil; exploração das duas maiores bacias fluviaes do mundo; do Amazonas ao Pratá, etc. O Novo Mundo, III, 41-43. New York, Dezembro 23, 1872.

MAGALHÃES, DR. JOSE VIEIRA COUTO DE: Ensaio de Anthropología. Religiões e raças selvagens. Revista Inst. Hist., XXXVI, Parte II. Periodo geologico a que correspondem os mais antigos vestigios humanos no Brazil, 416-420. Rio de Janeiro, 1873.

MAGALHÃES, COUTO DE: O Salvagem-Parte II, Origens, costumes e Religião Selvagem. Cap. II, O homem no Brazil, 23-24; periodo geologico a que correspondem os mais antigos vestigios humanos no Brazil, $34-39$. $8^{\circ}$. Rio de Janeiro, 1876.

MALAISE, C.: Rapport sur le travail de M. Renard, intitule: "Notice sur les roches de l'ile de Fernando Noronha, recueillies pendant l'expedition da Challenger." Bull. de la Acud. royale des sciences, etc., 3e sér., III, 321322. Bruxelles, 1882.

MALTE-BRUN: Voyage a la Cochinchine par les lles de Madere . . . le Brésil et l'Ile de Java ... Par John Barrow. Traduit de l'Anglais, avec des notes et additions. Par Malte Brun. Tome 1er. Paris, 1807. Chapltre IV, Mémoire sur le Brésil, par le traducteur. Geology, physical features, and minerals, 154-173. The part regarding diamonds is reproduced in the Bibliotheque Universelle des Voyages, etc. Par G. Boucher de la Richarderie. VI, 296-297. Paris, 1808.

MANÇO, JOÃo: O fossil do Bom Successo. Experiencias sobre o fossil do Bom Successo, existente nas fraldas do Monte Itacoluml em Vr. Ra. (S. João d'El-Rey, 5 de Julho de 1808.) Revista do Archivo Publico Mineiro. Anno II, fas. 4, Out. a Dez. de 1897, 253-254. Ouro Preto, 1897. 
MANGIN, ABTHUR: Pierres et meteaux. Alfred Mame et fils. $\mathbf{8}^{\bullet}$, ill., 388 pp, Tours, 1871. (Brazilian topazes and diamonds.)

MANNHEIM, E. A.: Relatorio sobre algumas condições mineralogicas no estado do Rio Grande do Sul. Correio do Povo, Porto Alegre, 19 de Março de 1908.

MANOEI Thimotheo da Costa: v. ALMEIDA, FRANCISCO ANTONIO DE.

MANSELL, F. W.: Argentine and St. John del Rey. (Gold mines.) Mining Journal, XLV, 1359. London, 1875.

MANSON, MARSDEN: 'The cosmic character of the ice age. The Glacialist's Magazine, II, No. 5, 97-100; No. 6, 107-114. $8^{\circ}$ : London, 1895.

MANSON, MARSDEN: The evolution of climates. American Geologist, XXIV, 93-120. Minneapolis, August, 1899. Also separate, Satl Francisco, 1899. (Glaciation of Brazil, 111-116.)

MARAJo, BARÃO DE: As regiões Amazonicas. Estudos chorographlcos dos Estados do Gram Paŕ e Amazonas. 404 pp. Lisbôa, 1895.

MARAJó, BARÃO DE: [O Para em 1900. Quarto centenario do descobrimento do Brazil. Publicação commemorativa feita pelo governo do Estado. $4^{\circ}$. Para, 1900.] Geographia physica, 5-13; caracteres geologicos, 13-16.

MARC, ALFRED: L'exposition de 1889. La Province de Minas Geraes a la section brésilienne. Extrait: Journal Le Brésil, no. 236 et suivants. 36 pages. Paris, 1889.

MARC, ALFRED: Le Brésil; excursion a travers ses 20 provinces. edité par M. J. G. D'Argollo-Ferrão. $8^{\circ}, 2$ vols. Paris, 1889. Notes ou geology and mineral resources: Cear氏 I, 185-188; Pernambuco I, 219, 230; Sergipe I, 294; Minas Geraes II, 14-20, 65-67; São Paulo II, 175-177; Paraná and Santa Catherina II, 377-379, 422; La houille de Tubarão II, 438-441; Rio Grande do Sul II, 476-477; Matto Grosso II, 529-532, 556-559.

MARCOU, JULES: Explication d'une seconde édition de la carte géologique de la terre. Folio, Zirrich, 1875. (Map on scale of $1: 23,000,000$; Brazil, 166-170.)

MARCOU, J.: $\nabla$. AGASSIZ, I.

MARCOU, JULES, and MARCOU, JOHN BELKNAP: Mapoteca geologica Americana. A catalogue of geological maps of America (North and South). Bulletin No. 7 of the U. S. Geological Survey. Washington, 1884. Maps of Guiana and Brazil, 153.

MARCOU, JULES: Glaciers and glacialists. Science, VIII, 76-80. New York, 1886. Notes Agassiz's theory regarding the glaciation of Brazil, 78.

MARCOU, JULES: Life, letters and works of Louis Agassiz. 2 vols., $8^{\circ}$. New York, Macmillan \& Co, 1892. II, Chap. XX, 144-160, and 187, contains notes regarding the work of Agassiz in Brazil.

MARqUES, ABIrTo A. S.: As ostreiras de Santos e os kjoklenmoddings da Dinamarca. Revista Brazileira, VI, 185. Rio de Janeiro, 1880.

MARQUES, SEZAR AUGUSTO: Diccionario historico-geographico da Provincia do Maranhão. $4^{\circ}$. Maranhão, 1870 . Sal, p. 104; minas, 374 ; salitre, 489 ; tremores de terra, 531 ; dunas, $459-460$; chumbo, 518-520; Minas de Chapada, 137.

MARQUEZ DE SOUZA: $\nabla$. SOUZA, C. M. DA.

MARSH, 0 . C.: Notice of some new reptilian remains from the Cretaceous of Brazil. American Journal of Science, XCVII, 390-392. New Haven, 1869.

MARTINI, J.: Beiträge zur Kenntnis des Quarzes. Neues Jahrbuch für Mineralogie, 1905. Bd. II, 43. Bergkristall aus Brasilien, 55-65; Gelber und brauner Bergkristall und Rauchtopas aus Brasilien, 66-68; Amethyst, 7273. Ill. Stuttgart, 1905.

MARTINS, J. P. OLIVEIRA: O Brazil e as colonias Portuguezas. 2a. edluăo, Lishoa, 1881 . $8^{\circ}$. A descoberta das minas, $75-80$; o ouro do Brazil, 80-86. 
MARTIUS, DR. VON: tuber die neuerlich in der Serra de Sincurá im Sertão der Provinz Bahia ausgefundenen Diamanten-Lokalitäten. Gelehrte Anzeigen: Bulletin der $k$. baycr. Academie der Wissenschaften, Part II, No. 197, 545-547. München, 1846.

MARTIUS, C. F. PH. DE: Historia naturalis palmarum. See Unger, $F$.

MARTIUS: $\nabla$. SPIX und.

MASSENA, JOSE FRANKIIN: Tabela das altitudes sobre o nivel do oceano dos principaes Iugares e montes da carta topografica de Minas Geraes. Revista Ins. Hist., XLV, parte I, 151-155. Rio de Janeiro, 1882.

MASSENA, JOSE FRANKIIN DA SILVA: Investigacõos scientificas para o progresso da geologia mineira. O. D. C. ao Instituto Historico e Geographico Brasileiro * * * em 1867. Revista do Inst. Hist., XIVII, 249-281, 1 rection. (Datada Barra Mansa, 3 de Maio de 1887.) rRio de Jaueiro, 1884.

MATHEW, G. F.: Charles Frederick Hartt. Bulletin of the Natural History Society of New Brunswick, No. IX, 1-24. $8^{\circ}$. St. John, N. B., 1890.

MATTOS, RAIMUNDO JOSt DA cUNHA: Itinerario do Rio de Janeiro no I'arñ e Maranhão pelas provincias de Minas Geraes e Goiaz, seguido de huma descripgão chorographica de Goiaz, e dos roteiros desta provincia ás de Matto Grosso e São Paulo. 2 tomes. Rio de Janeiro, 1836. ( $I$, pl). $12,14,32,40,93,137,190,195,203,206,228,231-233,235,238,245,253$, 260 ; II, plysical features, $6-13,46-48,308$; geology, 7-8, 19-21, 25, 29, 89, $122,239,310-315$.

MATTOS, RAYMUNDO JOSE DA CUNHA: Chorographia historica da provincia de Goyaz. Revista do Instituto Historico, XXXVII, Parte I. Lagoas, 267; montanhas, 268-269 (geology) ; terreno, 271; mineraes, 275 ; mineral!ão, 291. Rio de Janeiro, 1874. Revista Inst. Hist., XXXVIII, Parte I, natureza do terreno, 5-6; mineraes, 7-8; mineração, 14-16. Rlo de Janeiro, 1875.

MAUBEUGE, G. LAVELAINE DE: Voyage de l'aviso a vapeur le "Tenare" surr la côte septentrionale du Brésil. Nouvelles Annales des Voyages, 1858, I, 257-274. Paris, 1858.

MAWE, JOHN: A treatise on diamonds and precious stones, including their history-natural and commercial. London, 1813. Brazilian stones, pp. 28-45, 93-119.

MAWE, JOHN: Travels in the interior of Brazil, particularly in the gold and diamond districts of that country, by authority of the Prince Regent of' Portugal . . . Philadelphia. Ill., $8^{\circ}, 374$ pages. Boston, 1816. 1st edition, $4^{\circ}$, VIII +367 pp. Review of 1st edition: Taschenbuch fïr Mincralogie, von Leonhard, $12 \mathrm{er}$ Jahrgang, 524-527. Frankfurt am Main, 1818.

'Travels in the interior of Brazil; with notices on its climate, agriculture, commerce, population, mines, mamuers, and customs, and a particular account of the gold and diamond districts. . . B By John Mawe. Second edition. Illustrated with colored plates. $8^{\circ}, \mathrm{xi}+494$ pages. London, 1821. Dutch ed. Reize in de Binnendeelen van Brazillë, vooral in deszelfs Goud-en Diamantrijke Streeken, etc. Bij François Bohn. $8^{\circ}, 2$ vols. Te Haarlem, 1817.

MAWE, J.: Reisen in d. Innere v. Brasilien, vorziigl. nach d. dortigen Goldund Diamantdistrikten. N. e. Reise nach dem Isa Platafluss; a. d. Engl. $8^{\circ}, 2$ Bd. Gr. Hamburg. 1816.

MAWE, GIO.: Viaggio nell' interno del Brasile e particolarmente nei Distretti dell' oro e dei diamanti fatto nel, 1809-1810, etc. 2 vols. Milano, 1817.

MAWE, JEAN: Voyages dans l'intérieur du Brésil, particulierement dans les districts de l'or et du diamant. faits avec l'autorisation du Prince Régent de Portugal, en 1809 e 1810 , contenant aussi un voyage au Rio de la Platit et un essai historique sur la révolution de Buenos-Ayres. Traduit de 
l'anglais par J. B. Eyriès. Enrichis de figures. Paris, 1816. 2 vol. in $8^{\circ}$, pp. xlii + 381. Extrait: Annales des Mines [2me sér.], If, 119-237. [Paris] 1817.

MAWE, JOHN: Nachrichten von dem Vorkommen und Gewinnen der Diamanten, anderer Edelsteine und edler Metalle in Brasilien. Gilbert's $A n$ nalen der Physik, N. F., LIX, 140-173. Leipzig, 1818.

MAWE: (The death of Mawe, Oct., 1829.) Bulletin des Sciences Naturelles et de Géologie, $\mathrm{x} \times, 432$. Paris, 1830.

MAWSON, JOSEPH: Lapa do Brejo Grande na Provincia de Bahia. Extract of a letter to O. A. Derby. Revista da Soc. de Geographia, do Rio de Janeiro, 1886, II, 102-103.

MAWSON, JOSEPH, and WOODWARD, A. SMITH: On the Cretaceous formation of Bahia (Brazil) and on the vertebrate fossils contained therein. Geological llagazine, 93-94, no. 512. London, Feb., 1907. Quart. Jour. Geol. Soc., LXIII, 128-139. London, May, 1907.

MAXIMILIAN, PRINZ ZU WIED-NEUWIED: Reise nach Brasilien, in d. Jahre. 1815 bis 17. Mit Anhang: Sprachproben d. Urvölker Brasiliens. 2 Bede. Mit 3 Krtn., 22 Taf. (5 in Chromo) u. 19 Vign. Gr.4. Atlas Fol. Kart. Frankfurt, 1820-1821.

Voyages au Brésil, dans les unneťs, $1815-1816$ et 1817. Par S. A. S. Maximilian, Prince de Wied-Neuwied; traduit de l'Allemand par J. B. B. Eyriès. Ouvrage enrichi diun superbe atlas, composé de 41 planches gravées en taille-donce et de trois cartes. Paris, $12^{\circ}$, Tome 1er, 1812 , pl). xiv +399 ; tome 2and 1821 , pp. iii +400 ; tome $3 m e, 1822$, pp. iii +384 (Contain notes on the geology between Rio and Bahia). Abstract: Nou. velles ann. des Voyages, XVIII, 89-97. Paris, 1823.

About half of this work was translated into English under the title: Travels in Brazil in the years 1815, 1816, 1817. By Prince Maximilian, of Wied Neuwied. Illustrated with plates. London, $1820.4^{\circ}$, vili +335 pages. (This is all that was translated into English, and includes vol. I of the French ed. and chap. XI of vol. II up to p. 206.)

Dutch edition: Reize naar Brazilië, in de jaren 1815 tot 1817 door Maximiliaan, Prins van Wied-Neuwied, $8^{\circ}, 2$ vols. Te Groningen. Holland, 1822.

MAY, DR.: Aguas sulphurosas alcalinas do Araxá, provincia de Minas. Do Jornal do Commercio do Rio de Janeiro. Revista Industrial, Marco, 1879, IV, 78-79. New York, 1879.

MEDRADO, ALCIDES: Revista Industrial de Minas Geraes. Director, Alcides Medrado. Publicação mensal, auxiliada pelo Governo do Estado. Anno I. Ouro I'reto, 15 de Outubro de 1893, No. 1. Ouro Preto, 1893. Anno VII. Ouro Preto, 10 de Setembro de 1899 , No. $1 . \quad\left(1080\right.$ pages, $\left.4^{\circ}.\right)$ Contains many articles upon geology and mineralogy of Brazil. Review of vol. I by Hussak. Zeitschrift für praktische Geologie, April, 1894, 162-163. Berlin, 1894 .

MEDRADO, A.: (Monazite in Brazil with analysis.) Consular Reports (U. S.), L, 372-373. Washington, 1896. ('The name is erroneously spelled "Midrados.")

MEDRADO, ARCHIAS, e OLIVEIRA, FRANCISCo DE PAULA: Notice redigée d'après les rapports des travaux exécutês $*^{*}{ }^{*}$ sur l'exploration du gisement de Cinabre de Tres Cruzes. Revista Industrial de Minas Geraes, Anno III, No. 17, 15 de Maio de .1896, 191-198. Ouro Preto, 1896.

MEDRADO, ALCIDES: A Brazilian iron plant. (Ill.) Engineering and Mining Journal, Nov. 9, 1901, LXXII, 599. New York, 1901.

MEDRADO, ALCIDES: Mines and minerals in the States of Minas Geraes and Bahia, Brazil. Monthly Bulletin of the Bureau of American Republics, vol. XII, 100-134. Washington. 1902 .

MEDRADO, ALCIDES: Historical sketch of gold mining in Minas Geraes, Brazil. Engineering and Mining Journal, vol. IXXIII, 447, March 29, 1902. Also in Brazilian Mining Review, I, 21-22, 23-33. Ouro Preto, 1902. 
MEDRADO, ALCIDES: Brazilian Mining Review. Ouro Preto, Mines Gertes,

Brazil. Alcides Medrado, Editor.

Volume 1, No. 1, Ouro Preto, July, 1902. $4^{\circ}$.

Volume 1, No. 2, Rio de Janeiro, August, 1902.

Volume 1, No. 3, Rio de Janeiro, July, 1903.

Volume 1, No. 4, Rio de Janeiro (no other date), 1903.

Volume 1, No. 5, Rio de Janeiro (no other date), 1903.

Volume 1, No. 6, Rio de Janeiro, January, 1904.

Volume 1, No. 7, Rio de Janeiro, February, 1904.

Volume 1, No. 8, Rio de Janeiro, March, 1904.

Volume 1, No. 9, Rio de Janeiro, April, 1904.

Volume 1, No. 10, Rio de Janeiro, May, 1904.

(Published in English, and containing articles upon mines, mining, geology and mineralogy. Many of them are reproductions in English of articles previously published in Portuguese, French and English.)

MEEWARTH, H.: Reisebilder von Mündungsgebeit des Amazonas. Verhalt. Natw. 3 Folge, VIII, X-XI, XXIII-XXIV. Hamburg, 1901.

MFEWARTH, H.: Eine geologische Forschungreise nach dem Rio Acará im Staate Pará. Globus, 86, 289, 309. IIl. Braunschweig, 1904.

MEIGS, C. D.: An account of some human bones found on the coast of Brazil near Santas (sic). Trans. Amer. Phil. Soc. New ser., III, 285-291. Philadelphia, 1830.

MEIRA DE VAŚCONCELLOS: v. VASCONCELLOS, J. F. M. DE.

MEIRELIES, OZORIO REZENDE: Terra Roxa do Oeste de S. Paulo. Revista Ináustrial de Minas Geraes; Anno III, No. 17, 211-213, 15 de Maio de 1896.

MELLO, FĖANCISCO IGNACIO MARCONDES HOMEM DE: Excursões pelo Ceara, S. Pedro do Sul e s. Paulo. Revist. Inst. Hist., XXXV, Parte II, 80-169, with maps. Rio de Janeiro, 1872. Notes on physical features.

MELLO, FOMEM DE: Subsidios para a organisaça da carta pliysica do Brazil. Estudo geographico pelo Conselheiro F. I. M. Homem de Mello. $4^{\circ}, \mathrm{pp}$. $45 . \quad$ Rio de Janeiro, 1876.

MELLO, HOMEM DE (?): Perfis longitudinaes mostrando o relevo do solo em differentes secçoes do territorio Brazileiro. Dos subsidios para a organlzação da carta physica do Brazil. Auxiliador da Industria Nacional, No. 6, XLVII, 129-131. Rio de Janeiro, Junho, 1879.

MELLO, BARÃO HOMEM DE: A orographia brazileira; o systema geographico do relevo da costa; a Serra do Mar. Revista Brazileira, Jan., 1895, I, 116-Brazil ; 123. Rio de Janeiro, 1895.

MELLO, BARÃO HOMEM DE: A orographia brazileira. Cordilheiras e serras do interior, Serra da Martiqueira. Revista Brazileira, II, 350-355. Rio de Janeiro, Junho, 1895.

MELLO, HOMEM DE: Lagôa Santa, Estado de Minas. Revista Industrial de Minas Geraes, Anno V, No. 25, 12. Ouro Preto, 20 de Junho, 1897. (Extracto do Jornal do Commercio do Rio de Janeiro.)

MELLO, BRANDÃo P. DE: As aguas mineraes de Araxá, Rio de Janeiro, 1886,22 pp. Contém uma carta de 0 . A. Derby sobre a geologia da região.

MENEZES, GUSTAVO ADOLPHO DE: Riqueza mineral do Estado da Bahia. Fxtracto de um relatorio apresentado em 1863 ao Presidente Cons. Sa e Albuquerque. Revista Trimensal do Inst. Geographico e Historico da Bahia, IV, 233-240. Bahia, Junho, 1897. Also in Diccionario Geographico das Minas do Brazil por Francisco Ignacio Ferreira, 218-242. Rlo de Janeíro, 1885.

MERRILI, GEORGE P.: Contributions to the history of American geology. Report of the U. S. National Museum for 1904. (Work of Hartt in Brazil, 529-530.) Washington, 1906.

MESSEDER, JOAO CAIDEIRA DE ALVARENGA: v. CAMPOS, IUIZ F. GONZAGA DE. 
MEUNIFR, STANISLAS: Fer natif du Brésil. La Nature, 1877, V, 79. (The Sta. Catharina mass mentioned.)

MEUNIER, STANISLAS: Sur le mode de formation de la brèche métèorique de Sainte-Catherine (Brésil). Comptes Rendus de l'Acad. Sci., LXXXVI, 943-946. Paris, 1878.

MEUNIER, STANISLAs: Exploration géologique au Brésil. La Nature, 1880, VIII, l'annee, p. 63. Paris, 1880. (Derby's work.)

MEYTR, HERRMANN: Ueber seine Expedition nach Central-Brasilien (Matto Grosso). Verhandlungen der Gesellschaft für Erdkunde zu Berlin, XXIV, 172-198. Berlin, 1897.

MEYER, HERRMANN: Bericht über seine zweite Xingú-Expedition. Verhandlungen der Gesellschaft für Erdkunde zu Berlin, XXVII, 112-133. Berlin, 1900.

MEYERS: Meyers' Konversations-Lexikon. $4^{\circ}$, 5te Auflage. III. Physische Verhältnisse, 394-395. Geologisches Verhältnisse, 395. Bergbau Verhältnisse, 400. Leipzig and Wien, 1897.

MEZGER, ADOLPH: Report of the mines of Passagem, Raposos and Espirito Santo. Paris, 1885.

MEZGER, A.: The ore deposits and mines of Minas Geraes, Brazil. (Prepared by $\mathbf{R}$. W. Raymond from the unpublished notes of A. Mezger.) Engineering and Mining Journal, L, 239, 272-273. New York, 1890.

MFZGER, C. A.: The monazite districts of North and South Carolina. Trans. Am. Inst. Min. Eng., XXV, 822-826 ; references to Rio granites, 823,1038 1039. New York, 1895.

MICHAEII, JOAQUIM G.: The manganese deposits of Gandarella, Minas Geraes, Brazil. Engineering and Mining Journal, Dec. 21, 1901, LXXII, 818. New York, 1901. Also in Brazilian Mining Revievo, I, 22-23. Ouro Preto, July, 1902.

MICA: See Glimmerlager.

MIFBS, JOHN: (Coal in Brazil.) Report of the commissioners appointed to inquire into the several matters relating to coal in the United Kingdom, $8^{\circ}$, III, 261-263. London, 1871. This article is also to be credited to Nathaniel Plant.

MILET-MUREAU, I. A.: Voyage de la Pérouse autour du monde etc., et rédigé par M. L. A. Milet-Mureau. sm. $8^{\circ}$. Paris, 1798. Martin Vaz and Trin!dade II, 28-34; notes that the rocks are basalt.

MIIL, H. R.: See Batalha-Reis.

MILLS, JAMES E.: São Cyriaco gold mines, Province of Minas Geraes, Bra. zil. (A report made to Messrs. Riedel, Rader \& Co., dated Rio de Janeiro, Dec. 18, 1875.) $8^{\circ}, 20$ pp., 2 maps and illustration. Appendix A, pp. 14-18 is upon geological details. (n. $\bar{d}$. or loc.)

MIILS, JAMES E.: As minas de ouro de S. Cyriaco na provincia de Minas Geraes. Revista Industrial, Junho de 1878. Vol. II, 171-173. Dated Rio de Janeiro, 18 de Dez. de 1875. New York, 1878. Portuguese translation of the preceding.

MILIS, JAMES E.: Quaternary deposits and quaternary or recent elevation of regions and mountains in Brazil with deductions as to the origin of loess from its observed conditions there. American Geologist, III, 345. 361. Also separate, Minneapolis, 1889.

MII.LS, JAMES E.: Notes upon the surface geology of Rio Grande do Sul, Brazil, edited by J. C. Branner. American Geologist, Feb., 1902, vol. XXIX, 126-127.

MIILs, L. D.: Analysis of limestone from near Penha. (Rio Grande do Norte.) Bull. Geol. Soc. Amer., XIII, p. 96. Rochester, 1902,

MIINE, G. T.: The industrial resources of the State of Matto Grosso. Braztl. Journal of the Society of Arts, LIII, 575-587. London. April 14, 1905.

MIINE, G. T.: Wealth of Central Brazil. Brazilian Engineering and Mining Reviev, II, 57-58. Rio de Janeiro, April, 1905. 
(MINAs:) Mining enterprise in Brazil. The Mining Journal (Supplement to), Aug. 11, 1883, LII, 937. London, 1883.

MINOR, J. C.: See Penfield, s. L.

MIRANDA, JOAQUTM VELLOSO DE: Officio sobre a extraccão do salitre na Capitania (1801). Revista do Archivo Publico Mineiro, Anno III, fas. II, 273-274. Bello Horizonte, 1898.

MODERN TRAVELER, THE: The modern traveler. A popular description, geographical, historical, and topographical, of the various countries of the globe. Brazil and Buenos Ayres, $12^{\circ}$, I, 1825. (Natural history, 79-87; gold mines of Jaragua, 248-250 ; iron mines of Ypanema, 251-254; Minas Geraes geology and mines, 1-106; etc.) $12^{\circ}$, II. London, 1825.

MOISSAN, HENRI: Etude du diamant noil. Comptes Rendus, CXXIII, 210 211. Paris, 1896.

MOISSAN, HENRI: Sur un échantillon de carbon noir du Brésil. Comptcs Rendus de l'Acad. des Sci., CXXI, 449-450. Paris, 1895. Abstract: Nenes Jahrbuch fiir Mineral., 1896, II, 407 (Referate). Abstract: Zeitschifi für Krystalog. und Mineralog., XXVII, 540. Leipzig, 1896.

MOISSAN, HENRI: tude des sables diamantifères du Biesil. Comptes Rendus de l'Acad. des Sci., CXXIII, 277-278. Paris, 1896. Abstract: Neues Jahrbuch für Mineral., 1898, II, 18T (Referate). Abstract: Zeitscrift für Krystalog. und Mineralog., XXIX, 413-414. Leipzig, 1898.

MONAsTERIO, ANGEL DE: Sur le fleuve Paraná et ses afluents. (Traduit de l'espagnol par M. Dalaroquette.) Nouvelles Annales des Voyages, XVII, 120-130. Paris, 1823.

MONCHOT: Gisements aurifères du district d'Ouro Preto, province de Minas Geraes (Brésil). Mémoires et Comptes Rendus des Travanx de la Société des Ingénieurs Civils. Avril, 1884. 4e série, 37 Année, 4e cahier, T. I, 461-486, 2 maps. $8^{\circ}$. Paris, 1884. Chapitre sur la géologie.

MONCHOT, CHARLES: Gisements auriféres du district d'Ouro Preto, province de Minas Geraes (Brésil). Extrait des Mémoires de la Société des litgenieurs Civils. $8^{\circ}, 26$ pp., 1 planche. Paris, 1884. (See above for the original.)

MONCHOT, CHARLES: Rapport sur les mines de Rapozos, Espirito Santo, Borges e Passagem, district d'Ouro Preto, Prorince de Minas Geries, Brésil. $4^{\circ}, 11$ pages. Paris, 1884.

MONNERON, DE: Ile de la Trinité. Observations de M. de Monneron. Voyage de la Pérouse autour du monde, publié conformément ou decret du 22 Avril, 1791, et rédigé par M. L. A. Milet-Mureau. . . . Tome second. Iondres, 1799. $4^{\circ}, 387-389$. (Dated 25 Oct., 1785.) Another section, $8^{\circ}$. Paris, 1798, has M. de Monneron's paper, IV, 104-107. (See also under La Pérouse.)

MONLEVADE, DE: Mineraux envoyés au Brêsil du cabinet de l'Ecole Royale des Mines. Annales des Mines, IV, 135-137. Paris, 1819.

MONTEIRO DE BARROS, LUIZ: $\nabla$. DERBY and.

MONTRAVEL, TARDYDE: Mémoire sur la découverte du fleuve des Amazones. Extrait: Comptes Rendus de l'Acad., XLIV, 602-604. Paris, 1857.

MOREAS, EDUARDo JOSE DE: A via de communicação a Mato Grosso. Memoria apresentada á consideracão do governo Imperial. (Annexo ao Relatorio apresentade $\mathfrak{a}$ assemblia geral legislativa na 1a sessão da 15a legislatura pelo Ministro e Secretario de Estado dos Negocios da Agricultura, etc. Francisco do Rego Barros Barreto.) $4^{\circ}$. Rio de Janeiro. 1872. Notas sobre a geologia do Rio Uruguay. 25: sal gemma no valle do Ivahy. 69.

MOREAS, EDWARDo JOSE DE: Estudos definitivos da linha de Cangussí. variante da Estrada de ferro do Rio Grande a Alegrete. . . . Memoria justificativa apresentada por Eduardo José de Moreas. Chefe da commissão. $4^{\circ}$. Rio de Janeiro, 1876. Descripção geral da zona do projecto. Geologia, etc., 12-15. Quotations from Sellow and Gorceix on the geology. 
MORAES REGO, FABIO HOSTILIO DE: v. CAMPOS, LUIZ F. GONZAGA DE.

MOREIRA, CARLOS e HEMENDORFF E.: Excursões no Itatiaia, Selra de Mantiqueira. Archivos do Museu Nacional, XII, 159 et seq. Rio de Janeiro, 1903.

MORGAN, ALFREDO: A note on itacolumite or flexible saudstone. Proceerings of the Liverpool Geological Society, III, pt. II, 148-151. I Liverpool, 1876. Abstract: The Geological Record for 1876, 210. London, 1878.

MORGAN, C. LLOYD: On the drift of Brazil. Royal School of Mines Magazine, II, 3-T. London, 187T. Abstract: Quar. Jour. Geol. Soc., vol. XXXII, Proceedings, 129-130. London, 1876. Abstract: Philosophical Magazine, 5th ser., II, 316. London, 1876.

MORNAY, A. F.: An account of the discorery of a inass of native iron in Brazil. Philosophical Trans. of the Roy. Soc. of London for the year 1816. Part I, 270-280, one plate. London, 1816. Abstract: Schweigger's Journal für Chemie, XXIII, 300. Review: Taschenbuch für Mineralogie von Leonhard, 15er Jahrgang. 551-55f. Frankfurt a. Main, 1821.

MORRIS, JOHN: On the discovery of some fossil remains near Bahia in South America by S. Allport. Note on the Molluscan remain from Monserrate. Quart. Jour. Geol. Soc., XVI, 266. London, 1860.

MOSELEY, H. N.: The Challenger expedition. II, Fernando de Noronha. La Nature, IX, 388-389. London, 1874.

MOSELEY, H. N.: $\nabla$. CHALLENGER.

MOUCHEz, ERNEST: Les côtes du Brésil, description et iustructions nautiques. Primière section, du Cap San Roque a Bahia. $8^{\circ}, 166$ pp. Paris, 1874. 2e section, de Bahia a Rio-Janeiro. Seconde édition-avec un supplement comprenant la côte de Rio-Janeiro a la Plata. $8^{\circ}$, pp. VIII-325 supplement de $67 \mathrm{pp}$. Le supplement + Côtes du Brésil de Rio de Janeiro au Rio de la Plata, ills. la Trinité et Martin Vaz. Paris, 1876. Many notes upon the reefs and physical features of the const, and islands.

MOUNTENEY, BARCLAY: Selections from the various authors who have written concerning Brazil; more particularly respecting the Captaincy of Minas Geraes and the gold mines of that province. $8^{\circ}, 182$ pp., 1 chart. London, 1825. Chap. VIII on geology.

M., N. J. (NICOLAU JOAQUIM MOREIRA): Lapidação do diamante. Auxiliador da Industria Nacional, Marco de 1866, XXXIV, 105-111. Rio de Janeiro, 1866. Notes on the large diamonds and on diamond explorations.

MUELIER, FRITZ: Observacões sobre a fauna marinha da costa de Santa Catharina. Revista do Musen Paulista, III, 1898, 31-40. S. Paulo, 1898.

MUGGE, 0.: Martit von Brasilien. Neues Jahrbuch für Mineral., 1889, II, 246. Stuttgart, 1889.

MUGGE, O.: Die regelmässigen Verwachsungen von Mineralen Verschiedener Art. Nenes Jahrbuch für Mineralog., etc. Beilage Bd. XVI. Stuttgart, 1903. Brazilian ininerals, 344, 348, 392-394, 396-397, 420 .

MULLER, FRITZ: On Brazilian Kitchen Middens. Nature, XIII, 304-305. London, 1876. Abstract: The Geological Record for 1876, 138. London. 1878.

MƯLIER, WILHEIM: Ein Beitrag suz Kenntniss des Chiastoliths. Inaug.Diss., Jena, 1866. Abstract: Neues Jahrb. für Mineral., 1888, I, 175-176. Referate.

MULHALL, MICHAEL G.: Rio Grande do Sul and its German colonies. $8^{\circ}$. London, 1873. Geography and geology, 12-22; the coal fields of S. Jeronimo, 78-84.

MÜLHEIMS, A.: Ueber eine neue Art der Axenwinkelmessung und über dic Bestimmung von Brechungsexponenten mach der Methode der totalreflexion. Zeitschrift für Krystallographie und Mineralogie (Groth), XIV. Leipzig, 1888. ('Topaz von Brasilien. 226.)

MUNIZ, GARCIA: See BRANNER (Sergipe-Alagôas). 
MURRAY, JOHN: V. CHATLENGER.

MURRAY, JOHN: (Experiencia do carvão de Sta. Catharina.) Revista dé Engenharia, V, 229. Rio de Janeiro, 28 de Agosto, 1883.

MYERS, H. M. and P. v. N.: Life and nature under the tropics, or sketches of travel among the Andes and on the Oronoco, Rio Negro, and Amazons New York, 1871. Geology of the Amazonas, 296-302.

NADAILUAC, IE MARQUIS DE: L'Amérique préhistorique. $8^{\circ}, 219$ ills. Paris, G. Masson, 1882.

NADAILIAC, MARQUIS DE: Pre-historic America. Translated by N. d'Anvers. Edited by W. H. Dall. London, 1885. Occasional notes upon the Pleistocene geology of Brazil.

NERY, F. J, DE SANTA-ANNA: Le Brésil en 1889. Avec une rarte cle l'wmpire en chromo lithographie, etc. Ouvrage publie par les soins du syndicat du Comité fr'anco-brésilien pour l'Exposition Universelle de Paris . . . sous la direction de M. F. J. de Santa-Anna Nery. Paris. 1889. Chap. 1er Notions générales (after Capistrano d'Abreu and $\mathbf{A}$, do Valle Cabral), 1-10. Aspect pluysique (after Derby), 10-21. Chap. IV, Minéralogie par M. Henri Gorceix, 61-104.

NERY, F. J. SANTA-ANNA: Le pays des Amazones, l'El-Dorado, les terres a caoutchouc. Paris, 1885. Chap. II, Physical, geographical and geological notes.

Translated into English under the title, "The land of the Amazons." Translated from the French of Baron de Santa-Anna Nery, by George Humphrey, F. R. G. S. With frontispiece, illustrations and maps, pp. xifi405. New York, London, 1901.

NETTO, LADISLAU: (Exame das rochas da encosta do Corcovado.) Diario Official, Rio de Janeiro, 26 de Autobro de 1868.

NETTO, LADISLAU: Reposta á impugnaçâo do Sr. Dr. Capanema. Diario Official do Imperio do Brasil, p. 2, col. 2-4. Rio de Janeiro, 27 de Nov. de 1868.

NETTO, LADISIAU: Investigações historicas e scientificas sobre o Museu Nacional do Rio de Janeiro accompanhadas de uma breve noticia de suas collecçóes e publicadas por ordem do Ministro da Agricultura. $8^{\circ}$. Rio de Janeiro, 1870. Collections; work done; rocks and minerals, 226-248.

NETTO, LEDISLAU: Noticia acerca dos combustiveis mineraes do Brazil. precedida de algumas noções geraes sobre estes productos. Annexo ao Relatorio do Ministro da Agricultura, 8 pp, $4^{\circ}$. Rio de Janeiro, 1870.

NETTO, IADISLAU (PRESIDENTE): Relatorio da Companhia das Minas de Ouro e Cobre do Sul do Brazil, apresentado a Assembléa Geral extraordinaria em 15 de Outubro de $1874, \mathrm{pp} .14,12^{\circ}$. Rio de Janeiro, 1874.

NETTO, LADISLAU: Ie Musćum National de Rio de Janeiro et son influence sur les sciences naturelles. Paris, $1889.8^{\circ}, 87$ papers. Mention of geologists and geological work in Brazil.

NEUMANN, K.: Notizen ïber das Kïstenland der brasilianischen Provinzeu Parana und sĩo Paulo. Zeitschrift für allgemeine Erdkunde, N. F.. IX, 327-333. Berlin, 1860.

NEWBERRY, J. S.: On glaciers in the tropies. Annual of Scientific Discovery for 1868, 234. Boston, 1868.

NOGUEIRA, ALFREDO: Historia descriptiva do Rio da Prata e seus principaes affiuentes. navegação, etc. Revista da Sociedade de Geographia do Rio de Janeiro. IX. 73-128. Rio de Janeiro, 1893. Notas sobre a orographia e mineralogia.

NORDENSKIöLD, N. V.: Vorläufige Mittheilungen über ernenerte Untersuchungen der Fliissigkeitseinschlïsse im brasilianischen Topas. Neues Jahrbuch für Mineralogie. ete.. 1886. I, 242-244. Stuttgart, 1886. Abstract: Zeitschrift für Krystallographis und Mineralogie (Groth), XIII, 319-320. Lelpzig, 1888. 
NUSSER-ASPORT, CHR.: Die Diamantenproduction in Brasilien. Deutsch Rundschau für Geographie u. Statistik, XXII, 103-110. Berlin, 1899.

OFFRET, ALBERT: De la variation, sous l'influence de la chaleur, des indices de réfraction de quelques espèces minérales, dans l'étendue du spectre visible. Bul. Soc. Frangaise de Miner., XIII, 405-697. Paris, 1890. Brasilien minerals, 546, 606-615. Abstract: Zeitschrift für Krystallographie und Mineralogie (Groth), XXI, 296-298. Leipzig, 1893.

O., J.: Mining prospects in Brazil. The Mining Journal, June 9, 1866, XXXVI, 358. London, 1866.

o., S.: Mining prospects in Brazil. The Mining Journal, May 25, 1867, XXXVI, 338. London, 1867.

OLFERS, J. F. M. v.: Ueber das niedrige Felsenriff der Küste von Brasilien. Archiv für Mineralogie, Geognosie, Bergbau und Hïttenkunde. Hernusgegeben von Dr. C. J. B. Karsten, IV, 173-183. Berlin, 1832.

OIIVEIRA: $\nabla$. GABAGIIA.

OLIVEIRA, ANTONIO RODRIGUES VELLOSO DE: Memoria sobre a melhoramento da Provincia de S. Paulo, applicavel em grande parte ás provincias do Brasil. Revista do Inst. Hist., XXXI, Parte I, 5 et seq. Cap. VI. Das forjas e ferrarias, 68-69. Rio de Janeiro, 1868.

OLIVEIRA, CANDIDO BAPTISTA DE: Memoria sobre as condições geologicas do porto do Rio de Janeiro. Revista Brazileira, II, 57-72. Rio de Janeiro, 1859. (British Museum.)

OLIVEIRA, CLODOMIRO A. DE: A metallurgia de ferro em Minas. Annaes da Escola de Minas. No. 5, 55-112. Ouro Preto, 1902. No. 6, 12-81. Ouro Preto, 1903.

OLIVEIRA, CLODOMIRO A. DE: The metallurgy of iron in Minas. Brazilian Engineering and Mining Review, III, 129-131, 184-5.

OIIVEIRA, FRANCISCo DE PAULA: Itineraio geologico de Ouro Preto ao Rio Abaeté. Auxiliador da Industria Nacional, No. 11, XIVII, 245-251. Rio de Janeiro, Nov., 1879.

OLIVEIRA, FRANCISco DE PAULA: Exploração das minas de galena do Ribeirão do Chumbo, affluente de Abaeté e estudo da zona percorrida de Ouro Preto até esse logar. Annaes da Escola de Minas de Ouro Preto, No. 1, 1881, 35-94. Rio de Janeiro, 1881.

OIIVEIRA, FRANCISCo DE PAULA: Estudos siderurgicos na Provincia de Minas Geraes. Annaes da Escola de Minas de Ouro Preto, No. 3, 1884, 135194. Abstract: Jour. Iron and Steel Institute, 1885, I, 258. London, 1885.

OIIVEIRA, FRANCISCO DE PAULA, and HUSSAK, E.: Reconhecimento geologico do Valle do Rio Paranapanema. Boletim da Com. Geog. e Geol. da Provincia de S. Paulo, No. 2, 1889, 3-31. S. Paulo, 1889. Abstract: Neues Jahrbuch für Mineral., 1891, II, 303-304 (Referate).

OLIVEIRA, FRANCISCO DE PAULA: O ouro em S. Paulo. Contribuição para o estudo da mineração no Brazil. Rio de Janeiro, 1892.

OIIVEIRA, FRANCISCO DE PAULA: Valor das jazidas metalliferas no Brasil. Estado de Minas. Revista Industrial de Minas Geraes, Ouro Preto. Anno I, No. 2, 15 de Novembro de 1893, 40-42. No. 3, 15 de Dezembro de 1893, 67-68. No. 4, 15 de Janeiro de 1894, 89-92. No. 5, 15 de Fevereiro de 1894, 107-110. No. 8. 15 de Maio de 1894, 181-187. No. 9, 15 de Junho de 1894, 221-223. No. 12, 15 de Setembro de 1894, 300-302.

OLIVEIRA, FRANCISCO DE PAULA: A pequena industria extractiva mineral. Revista Industrial de Minas Geraes, Ouro Preto: Anno I, No. 4, 15 de Janeiro de 1894, 92-94. No. 5, 15 de Fevereiro de 1894, 117-119. No. 8, 15 de Maio de 1894, 203-205. No. 9, 15 de Junho de 1894, 225-226.

OLIVEIRA, FRANCISCo DE PAULA: Mineração do diamante. Revista Industrial de Minas Geraes. Anno $\mathrm{I}$, No. 8, 15 de Maio de 1894, 181-184. Ouro Preto, 1894. 
OIIVEIRA, FRANCISCo DE PAULA: Jazida de cinabrio das Tres Cruzes perto do Tripuhy. Revista Industvial de Minas Geraes. Anno I, No. 7, 15 de Äbril de 1894, 159-161. Ouro Preto, 1894.

OLIVEIRA, FRANCISCO DE PAULA: Vista geral sobre o aspecto physico da região do Novo Districto fiederal e dos valles dos rios Corumbá e $\mathbf{S}$. Bartholomeu, em Goyaz. Relatorio parcial. Commissão de Estudos da Nova Capital da União. Geologia, G. 3 to G. 8. Rio de Janeiro, 1896.

OLIVEIRA, FRANCISCO DE PAULA: Jazida de esmeril situada no Corrego do Paiol. Revista Inlustivial de Minas Geraes. Anno V, No. 28, 30 de Setembro de 1897, 49-51. Ouro Preto, 1897.

OLIVEIRA, FRANCISCOO DE PAULA: Noticia sobre as lavras diamantiferas do Cavallo Morto. Rio de Janeiro, 1899.

OLIVEIRA, FRANCISCo DE PAULA: Noticia sobre as jazidas mineraes do Gandarella. Revista Industrial de Minas Geraes. Anno IV, No. 22, 30 de Março de 1897, 275-276. Ouro Preto, 1897.

OLIVEIRA, FRANCISCo DE PAULA: Report addressed to Dr. Urbano Marcondes, chairman of the Aurifera Company of Minas Geraes. 45 pages; Rio de Janeiro, 1901.

OLIVEIRA, FRANCISCO DE PAULA: Minas de Ouro. Jornal do Commercio. Rio de Janeiro, Feb. 3, 1901.

OLIVEIRA, FRANCISCO DE PAULA: The diamond deposits of Salobro, Brazil. Engineering and Mining Journal, LXXII, 635-636. New York, Nor. 16, 1901. Also Brazilian Mining Review, I, 19-21. Ouro Preto, July, 1902.

OLIVEIRA, FRANCISCO DE PAULA: Baciạs Carboniferas do Brazil. Jornal do Commercio, Rio de Janeiro, Dez. 15, 1901.

OLIVEIRA, FRANCISCO DE PAULA: A molybdenita; estudo deste mineial e dos seus derivados. $8^{\circ}, 20 \mathrm{pp}$. Curityba, 1906.

OLIVEIRA, FRANCISCO DE PAULA: Aproveitamento do carvão nacional. $8^{\circ}, 27 \mathrm{pp}$. Curityba, 1906.

oLIVEIRA, FRANCISCO DE PAULA: Subsidios ao estudo da geologia do Brasil. $8^{\circ}, 29 \mathrm{pp}$. Curityba, 1907.

OLIVEIRA, MANOEL ANTO. VITAL DE: V. GABAGLIA.

OLIVEIRA, PAULO JOSE DE: Relatorio sobre Minas de carvĩo de pedra e ferro da Ilha de Itamarica. Annexo ao Relatorio do Ministro da Agricultura, $36 \mathrm{pp}$. Rio de Janeiro, 1864.

OIIVEIRA, PAULo JOSE DE: Exploração de Mineraes. Annexo ao Relatorio do Ministro da Agricultura, 19 pp. Rio de Janeiro, 1865. Many quotations from this paper in the Diccionario Geographico das Minas do Brazil por Franco Ignacio Ferreira. Rio de Janeiro, 1885.

OLIVEIRA, SATURNINO DE: (26 analyses de manganez do Brazil.) Annaes da Escola de Minas, No. 5, 192-197. Ouro Preto, 1902.

OLYNTHO, ANTONIO: V. PIRES.

ORBIGNY, ALCIDE D': Voyage dans l'Amérique Mêridionale, etc., III. $4 \mathrm{e}$ partie, $4^{\circ}$. Paleontologie. Paris, 1842. (Brazil, 13-15, 27, 141, 145-152.)

ORBIGNY, ALCIDE D': Voyage daus l'Amérique méridionale (le Brésil, la République Orientale de l'Uruguay (etc., etc.) ; executé pendant les années, 1826 (a) 1833. $4^{\circ}$. Paris, 1835-1847. Géologie, III, 3e partie. Paris, 1842.

ORBIGNY, ALCIDE D': Considérations générales et coup d'oeil d'ensemble sux les grands faits géologiques dont l'Amérique méridionale a éte le theatre. Comptes Rendus de l'Acad. Sci.. XV. 771-773. Paris, 1842.

ORBIGNY, ALCIDE D': Considérations générales sur la paléontologie de l'Amérique méridionale. comparée a la paleontologie de l'Europe. Bull. Soc. Geol., 1ere série, 1842-43, XIV, 352-353. Paris, 1843.

ORBIGNY, ALCIDE $D^{\prime}$ : Recherches sur les lois qui président a la distribution géographique des mollusques côtiers marins. Annales des Sci. Naturelles, 3me série, Zoologie, III, 193-221. Paris, 1845. 
ORTMANN, A. E.: Von Iherlng's Archiplata-Archelemis theory. Science, Dec. 14, 1900. New ser., XII, 929-930. New York, 1900.

ORTMANN, A. E.: The geographical distribution of fresh water decapods and its bearing upon ancient geography. Proc. Amer. Phil. Soc., XLI, No. 171, 267-400. Phíladelphia, Apr.-Dec., 1902.

ORTON, JAMES: Physical observations on the Andes and the Amazons. Amer. Jour. Sci., XCVI, 203-213. New Haven, 1868.

ORTON, JAMES: On the valley of the Amazon. Proc. Am. Assoc. Adv. Sci., 1869, XVIIII, 195-199. Cambridge, 1870.

ORTON, JAMES: On the evidence of a glacial epoch at the equator. Proc. Amer. Assoc. Adv. Sci., XIX, 185-193. Cambridge, 1871. Annals and Mag. Nat. Hist., VIII, 297-305. Isondon, 1871. Abstract: American Naturalist, IV, 566-567. Salem, 1871.

ORTON, JAMES: (Quotations upon the drift of the Amazon valley.) Annual of Scientific Discovery, for 1871, 245-246. Boston, 1871.

ORTON, JAMES: The Andes and the Amazon, or across the continent of \$outh America. Third edition, revised and enlarged, containing notes of a second journey across the continent from Para to Lima and Lake Titicaca. With two maps and many illustrations, pp. $645+$ XXIII. New York, 1876. Chap. XLI, The geological structure of the Amazons valley, 551-563. Chap. XIX, The valley of the Amazons, its physical geography. Geology, 280. Chap. VII, Geological history of South America . . . creation of the Amazons, etc., 114-126. Review of first edition in $O$ Novo Mundo Outubro. 1870. I, 14. New York, 1870. Notice and extracts: L'Explorateur Géographique et Commercial, III, 24-25. Paris, 1876.

ORTON, JAMES: Historia geologica da America do Sul. O Novo Mundo, Abril de 1878, VIII, 91. Excerptos e traducção da obra The Andes and the Amazon. New York, 1878.

OSBORN, HENRY F.: The reptilian subclasses Diapsida and Synapsida and the early history of the Diaptosauria. Memoirs of the American Museum of Natural History, I, part VIII. 451-507. Proganosauria (including Stereosternum from São Paulo, Brazil), 481-492, 4. ill. New York, Nov.. 1903.

O(SBORN), H. F.: Recent vertebrate paleontology. (Permian reptile from Brazil.) Science, XXIV, 1845, New York, Aug. 10, 1906.

OSSAT: $\nabla$. D'OSSAT.

OSSAT, G. DE ANGELIS D': Il Clisiophyllum Thildae n. sp. nel Pará. Atti della Reale Accademia dei Lincei, XII, 515-521. Roma, 1903. Description of a Carboniferous coral from Rio Tapajos.

OURO PRETO GOLD: (A letter on the Passagem mine.) The Mining Journal, Railway and Commercial Gazette, Nov. 19, 1887, LVII, 1393 . London, 1887.

OWEN, RICHARD: The continental type, or normal orography and geology of continents. Proc. Amer. Assoc. Adv. Sci. 32nd meeting, Minneapolis, 1883. Salem, 1884. Brazil, 259.

OZORIO DE ALMEIDA: V. ALMEIDA.

OZORIO REZENDE MEIRELLES: $v$. MEIRELLES, $0 . \mathbf{R}$.

PAKENHAM, MR.: (Letter to M. Thornton upon coal in Brazil.) Reports received from Her Majesty's Secretaries of Embassy and Legation respecting coal. With an appendix and reports as to coal production in British colonies. (In continuation of papers presented in 1866.) Presented to both Houses of Parliament by command of Her Majesty. Iondon, 1867. Accounts and papers of Parliament. session 5. Feb.-21 Aug.. 1867. $4^{\circ}$. LXX. 19-24. I London. 1867. Accompanied by papers from $\mathrm{N}$. Plant. I. Agassiz and W. G. Ginty.

PALDAOF, JOÃo M.: O Rio Grande do Sul e a magnesin. Jornal do Commercio de Porto Alegre, Oct.. 1904. 
PAPSTEIN, A.: Führer für den Auswander nach Brasilien. $12^{\circ}, 83$ pp. Berlin [1897?]. Geberge, 8; Mineralreich, 33-34.

PARIGOT, JULIO: Minas de carvão de pedra de Santa Catharina. $8^{\circ}, 12 \mathrm{pp}$. Rio de Janeiro, 1841.

PARIGOT, JULIO: Memoria sobre as minas de carvão de pedra do Brazll. $4^{\circ}, 30$ pp., with cut. Rio de Janeiro, 1841.

PARIGOT, JULIO: Memorla terceira sobre as minas de carvão de pedra de Santa Catharina. $4^{\circ}, 30 \mathrm{pp}$. Rio de Janeiro, 1842.

PARISH, WOODBINE: On the southern affluent of the river Amazons. Jour. Roy. Geog. Soc. of London, $\nabla, 90-101$. London, 1835.

PARTSCH, P.: Geognosticher und mineralogischer Anhang zum zweiten Bande (von Pohl's Relse im Innern von Brasilien, pp. 615-641). Wlen, 1837. V. Pohl.

PAULA OLIVEIRA: v. OLIVEIRA, F. DE P.

PAULCKE, W.: Ueber die Kriedefornation in Südamerika und thre Beziehungen zu anderen Gebieten. Neues Jahr-für Mineralogie, etc. Bellage Bd. XVII, 2 Heft, 252-312. Stuttgart, 1903. Brazil, 304. He says: "Kossmat puts the species found in Sergipe with the Cenomian and those found in the Province of Pernambuco between the chalk and the Tertlary."

PEARsON, HUGH: The gold field of Paracatí, Minas Geraes, Brazil. Transactions Institute Mining Engineers, XXXI, 257-263. 1906.

PEDERNEIRAS, INNOCENCIO VELLOSO: Carvão de pedra e mineraes de ferro da provincla do Rio Grande do Sul. Jornal.do Commercio, 17 de Abril de 1848. Rio de Janeiro. 1848. Coplado no Relatorio dos Estudos de Joåo Cordelro da Graça q. v. (X-XV).

PEDRO D'ALCANTARA: $\nabla$. ALCANTARA.

PEDRO AUGUSTO DE SAXE-COBURG: V. SAXE-COBURG.

PEDRO XAVIER DA VEIGA: . VEIGA, J. P. X. DA.

PELIKAN, A.: Teber Goethit, Iimonit und rothen Glaskopf. (from Ouro Petro). Tschermak's Minera7og. und Petrograph Mittheil., 1894. XIV, 1-12. Mit I Tafel. Wien, 1895. Abstract: Neues Iahrb. f. Mineral., 1895. II, 233. Referate.

PENFIELD, s. I., and MINOR, J. C.: Ueber die Chemische Zusammensetzung des Topas und deren Bezlehung zu seinen physikalischen Figenschnften. Zeitschrift für Krystallographie und Mineralogie (Groth), XXIII, 321-329. Telpzilg. 1894. Brazllian topaz. 326-327.

PENIsTON, W. M.: Public works in Permambuco in the Empire of Brazil. Minutes of Proceedings of the Institute of Civil Engineers, XXII, 385. London, 1863. Geology, 389.

PENNA, D. S. FERREIRA: O Tocantins e Anapu. Para, 1864.

PENNA, DOMINGOS S. FERREIRA: Breve noticia sobre os Sambaquis do Pará. Archivos do Museu Nacional, I, 85-99, $4^{\circ}$. Rio de Janeiro, 1876.

PENNY CXCLOP AEDIA: Brazil. The Penny Cvclopodia of the Soc. for the Diffusion of Useful Knowledge. $4^{\circ}$, V. I London, 1836. Brazll, 354-371.

PEREIRA, ANTONIO GUEDES: Minerios interessantes da Capitana. Offlclos ao governador Gomes Freire de Andrada (anno 1746). Revista do Archivo Publico Mineiro. Anno III, fas. II, 1898, 277-278. Bello Horlzonte, 1898.

PEREIRA CABRAL: $\nabla$. CABRAL.

PEREIRA DA COSTA: v. COSTA.

PEREIRA, FEiLIPPE FRANCISCo: Roteiro da costa do norte do Brazil desde Maceió até Pará. $8^{\circ}, 179 \mathrm{pp}$. Pernambuco, 1878.

PEREIRA, G. A.: Noticia sobre a descoberta das lavras diamantinas na Bahia. Revista Trimensal do Instituto Geographico e Historico da Bahia, VI, 75-80. Bahla, 1899. 
P., G. A.: Mineração (na Bahia). Boletim da Secretaria da Agricultura etc. do Estado da Bahia, IV, 155-158. Bahia, 1904.

PEREIRA, GONÇALO DE ATHAYDE: Memoria historica e descriptiva do Municipio de S. João do Paraguassú. Revista do Instituto Geogr. e Hist. da Bahia, XII, no. 31. Mineraes, pp. 130-135. Bahia, 1906. Published more at length separately. $8^{\circ}, 71 \mathrm{pp}$. Bahia, 1007 .

PEREIRA, GONGALO DE ATHAYDE: Mineração, suas necessidades etc. Boletim da Secretaria da Agricultura ctc. do Estado da Bahia, II, no. VI, 481-486. Bahia, 1903.

PEREIRA, GONÇALO DE A.: A nossa industria mineira. Boletim da Secretaria la Agr. da Bahia, no. II, an. I, pp. 26-31. Bahia, Junho, 1903.

PEREIRA, G. DE A.: Minas diamantiferas do Salobro. Boletim da Secretaria da Agr. da Bahia, VIII, 11-20. Bahia, 1906.

PEREIRA DA SILVA: $\nabla$. SILVA.

PEROUSE, IA: V. MILET-MUREAU.

PESSÔA, PAULA: Um notavel peixe fossil. (Notelops brama.) Renascença, II, No. 14, 177-179. Rio de Janeiro, April, 1905.

PETERMANN, A.: Die Französische Expedition nach den Central--Theilen Siid-Amerika's unter der Leitung das Grafen Francis de Castelnau in den Jahren, 1843-1847. Petermann's Mittheilungen, 159-181, 8. Gotba, 1857.

PHILLIPS, J. A.: The mining and inetallurgy of gold and silver, 79-87, 210220. London, 1867.

PHILlipS, J. ARTHUR: A treatise on ore deposits. Illustrated. London, 1884. Brazil, 613-616.

PHILIIPE, J. ARTHUR, and IJOUIS, HENRY: A treatise on ore deposits. Illustrated. London and New York, 2nd ed.. 1896. Brazil, 868-873.

PHIPSON, DR. T. L.: On a mineral from São Paolo (sic) (silicate of glucina phenakite). The Chemical Neus, XXI, 13. London, Jan. 14, 1870.

PIMENTA BUENO: $\nabla$. BUENO.

PIMENTEL, ANTONIO MARTINS DE AZEVEDO: O Brazil Central (estudos patrios). Revista do Instituto Historico, IXVIII, pt. II. Rio de Janeiro, 1907. $8^{\circ}, 116 \mathrm{pp}$ : (Geologia, pp. 16-55 of separate.)

PIMENTFI, ANTONIO: V. CRULS, L.

PIMENTEL, MANOEL: The Blazil pilot; or a description of the coast of Brazil. Translated from the Portuguese of Manoel Pimentel, principal hydrographer to His Majesty John the Fifth of Portugal, etc. $4^{\circ}$. London, 1809. (78 pages and charts.) Notes on the reefs and nature of the coasts.

PINHEIRO, JOSE FELICIANO FERNANDEZ, VISCONDE DE S. IEOPOIDO: Annaes da Provincia de S. Pedro. Segunda edição, $8^{\circ}$. Paris, 1839. Topography and geology, Chap. I, 15-41.

PINTO, ALFREDO MOREIRA: Geographia das provincias do Brazil. 3a edição, $8^{\circ}$. Rio de Janeiro, 1889. Aspecto physico, etc., XLII-XLVI ; geologia, XLVI-LIV.

PIRES, ANTONIO OLYNTHO DOS SANTOS: Viagem aos terrenos diamalltiferos do Abaeté. Annaes da Escola de Minas de Ouro Preto, No. 4. 93164. Rio de Janeiro, 1885.

PIRES, ANTONIO OLYNTHO DOS SANTOS: (Data regarding the manganese deposits of Minas) in The Manganese deposits of Bahia and Minas, Brazil. By J. C. Branner. Trans. Amer. Inst. Min. Eng., pp. 9-10 of separate; XXIX, 764-765. New York, 1899.

PIRES, ANTONIO OLYNTHO DOS SANTOS: A Mineraç̃o. Riquezas mineraes. Iivro do Centenario (1500-1900). III. 163 pp. Rio de Janeiro. 1902.

PIRES, ANTONIO OLYNTHO DOS SANTOS: A Serra da Piedade. Revista do Archivo Publico Mineiro. Anno VII. 813-826, Bello Horizonte. 1902. 
PIRES, ANTONIO OLYNTHO DOS SANTOS: Some mineral statistics of Brazil. Engineering and Mfining Journal, LXXIV, 673. New York. Nov. 22, 1902. Abstract : Mineral Industry, XI, 277-278, 462. New York, 1903.

PIRES, ANTO. OLYNTHO DOS SANTOS: The history of Brazilian mining. Brazilian Engineering and Mining Review, II, 18-20, 70-71, 84-85, 100-101, 115-117, 133, 149-152, 166, 170; vol. III, 9-11, 21-23.

PIRES, ANTONIO OLYNTHO DOS SANTOS: A minerção no Bresil. Riquezas Mineraes. Memoria por ——. Bello Horizonte, $8^{\circ}, 161$ pp., 1903. "Esta monographia foi publicada no Livro do Centenario III."

[PIRES, ANTONIO OIFNTHO DO SANTOS?]: [A riqueza mineral do Brazil.] A Federą̧ão, Porto Alegre. 2 Dec., 1904. Quoted from the $s t$. Louis Republic of St. Louis, Mo.

PIRES, ANTO. OLYNTHO: O Brazil em S. Luiz. Jornal do Commercio, Oct. 28, 1904. Montanhas de manganez; ouro exoortado, etc. Translated from the st. Louts Republic, Sept., 1904.

PIRES, ANTONIO OLYNTHO DOS SANTOS: Brazilian mining section at the Louisiana Purchase Exposition. Brazilian Engineering and Mining Review, II, 7-11. Rio de Janeiro, 1905.

PISANI, F.: Description de plusieurs mineraux. (Triphane du Bresil.) Comptes Rendus de l'Acad. Sci., LXXXIV, 1509-1510. Paris, 1877. Abstract: Zeitschrift für Krystallographie und Mineralogie (Groth), II, 109. Leipzig, 1878.

PISSIs, A.: Notice géognostique sur la province de Rio de Janeiro. Annales des Sciences Géologiques ou Archives de Géologie, etc., I, 244-249. Paris, 1842.

PISSIs, A.: Verkommen und Gewinnung des Goldes in Brasllien. Berg- u. Hütten m. Zelt., 752, 1842.

PISSIs (A.): Considérations générales sur les terrains du Brésil. Bull. Boc. Géologique, 1re série, 1841-42, XIII, 282-290. Paris, 1842.

PISSIS, A.: Mémoire sur la position géologique des terrains de la partie australe du Bresil et sur les soulevements qui, a diverses epoques, ont change le relief de cette contrée. Comptes Rendus de l'Acad. Sci., XIV, 10441046. Paris, 1842, in $4^{\circ}, 60$ pp., 2 cartes et 5 pl. Same title: Mem. de Inst. de France, $\mathrm{X}, 4^{\circ}, 353-413,2$ geol. maps, 3 plates of sections, 1 chart. Abstract: L'Institut, X, 230-231. Paris, 30 Juin, 1842.

PISSIs: Geologische Stellung der Gebirgsarten und Gebirgs-Hebungen in SüdBrasillen. Aus Dufrénoy's Kommissions-Berichte, l'Institut, 1843, XI, 221223. Abstract: Neues Jahrbuch für Mineral., 1844, 373-374.

PISSIS: Récherches sur les systêmes de soulévement de l'Amérique du Sud. Annales des Mines, 5e serie, IX, 81-146. Paris, 1857.

PISSIS, A.: Récherches sur les systémes de soulévement de l'Amérique du Sud. (Deuxieme partie.) Comptes Rendus de l'Acad. Sci., XLVI, 239-244. Paris, 1858.

PISSIS, A.: Memoria sobre a estructura geologica dos terrenos da parte austral do Brasil e sobre as solevações que em diversas epocas modificaram o relevo do solo desta região. (Mémoires de l'Acad., X, Paris, 1848, 353413.) Traduzida pelo Barão Homem de Mello. Revista do Inst. Hist., LI, pt. II, Supplemento, 147-151. Rio de Janeiro, 1888.

PITTA: See Rocha Pitta.

PLANT, JOHN: On the discovery of coal in Brazil. Trans. of the Manchester Geol. Soc., IV, No. 12, 294-304. Manchester, 1864. Also The Mining and Smelting Magazine, March, 1864, V, 148-151. London, 1864. Notice: The Mining Journal, Dec. 26, 1863 , XXXIII, 925. London, 1863. Notice: Cosmos; Revue Encyclopédique Hebdomidaire, XXV, 340-341. Paris, 1864. which is also quoted in Portuguese in $O$ A uxiliador da Industria Nacional, II, 471. Río de Janeiro, 1864 . 
PLANT, NATHANIEL: Report on the coal mines of River Jaguarão, in the Province of São Pedro do Rio Grande do Sul, Brasil. Report received from Her Majesty's Secretaries of Embassy and Legation respecting coal, etc. Presented to both Houses of Parliament, etc., 1867, 20-24. London, 1867. This forms part of the report of Mr. Parkenham, q. v.

PLANT, NATHANIEL: The Brazilian coal fields. Qeological Magazine, April, 1869, VI, 147-150. Separate pp. 1-4. Abstract: Newes Jahrb. f. Mineral., $1870,663-664$.

PLANT, NATHANIEL: (Coal in Brazil.) Report of the commissioners appointed to inquire into the several matters relating to coal in the United Kingdom. $4^{\circ}$, III, 261-263. London, 1871. The same article is listed under Miers; it is signed Nathaniel Plant and dated May, 1868.

PLANT, NATHANIEL: The coal-fields of the River Jaguarão and its tributaries, the rivers Candiota and Jaguarão-Chico, in the Province of Rio Grande do Sul. Appendix $\mathrm{H}$ of Brazil and the Brazilians. By Rev. James C. Fletcher and Rev. D. P. Kidder. 9th ed., 933-935. London, 1879.

PLATTNER: $\nabla$. IIAMPADIUS.

POEPPIG, EDUARD: Reise in Chile, Peru und auf dem Amazonenstrome während der Jahre 1827-1832. II Band. Leipzig, 1836. Reise auf dem Amazonenstrome bis Para, 7e Cap., 397-464, contains a few notes on the geology and physiography.

POHL, JOH. EM.: Beyträge zur Gebirgskunde Braziliens, nebst Aufzählung aller aingesammelten, und im k. k. Brazilianer Museum in Wien, aufbewahrten, einfachen und zusammengesetzten Fossilien. Von Dr. John Em. Pohl. Besonderer Abdruck aus dessen Reise im Innern von Brasilien. Erste Abtheilung mit einer lithographirten, geognostischen Ansicht. $4^{\circ}, 64$ pp, I geol. sect. Wien, 1832.

POHY, JOHANN EMANUEL: Reise im Innern von Brasilien. Auf allerhöchsten Befehl seiner Magestät des Kaisers von österreich, Franz des Ersten, in den Jahren 1817-1821 untergenommen und herausgegeben: von Johann Emanuel Pohl, ete., Erster Theil, mit vier grossen in Kupfer gestochenen Ansichen, einer ausgemalten Insecten, und einer Lithographirten, lllumenirten, geognostischen Tafel. $4^{\circ}, \mathbf{X X X}+448$. Wien, 1832. Most of the chapters have appendices upon the geology. Zweiter Theil. Mit drei in Kupfer gestochenen Ansichten, worunter jene von Rio de Janeiro in doppelter Grôsse, pp. XII + 641. Wien, 1837. An appendix upon the geology by $P$. Partsch is given on pp. 615-641.

POHI, J. E.: Extract de "Beiträge zur Gebirgskunde Brasiliens." Bull. Soc. Géol. de France, Ire série, V, 417. Paris, 1834.

POMPEU DE SOUZA BRAZIL, THOMAZ: Ensaio Estatistico da Provincla do Ceará. Cap. IV, aspecto physico, 9-26. Cap. $X$, constituição geologica, 4155, saltpeter 350. 8c. [Fortaleza?], 1863.

PONTES, M. J. P. DA SIIVA: Primeiros descobridores das minas do ouro na Capitania de Minas Geraes. Noticla compilada pelo Coronel Bento Fernandes Furtado de Mendonça e resumida por M. J. P. da Silva Pontes. Revista do Archivo Publico Mineiro. Anno IV, fas., I e II, 1899, 83-98. Bello Horizonte, 1899.

PORCHERON, H.: Rapport sur les mines de diamants de Agua Suja, dans l'itat de Minas Geraes, Brésil. av. 3 planches, . . . 1903.

PORTO SEGURO, VISCONDE DE: Historia geral do Brazil antes da sua separação e independencia de Portugal. 2a edição, 2 vols, I, XXVIII + 604 ; II, XII +616 (1220). $8^{\circ}$. Rio de Janeiro [n. d.] [1877]. Vol. II, Cap. XLII, minas d'ouro $e$ diamantes; Cap. LIII, minas de ferro; Cap. LIV, escriptores, viajantes, etc.

POSSNER, HEINRICH: Das Meteoreisen vom Bemdêgo in Brasillen. $8^{\circ}, 47$ pp., without date or place. A copy in the South Kensington Museum Library in London is bound up with Elfter Bericht der Naturforschenden Gesellschaft in Bamberg fur dle Jahre 1875 und 1876. Bamberg, 1876. ('The date Feh. 27, 1877, is mentioned on p. 46.) 
POURTAIES, I. P.: Voyage of the steamer Hassler from Boston to San Francisco. Report of the Superintendent of the U. S. Coast Survey [for] 1872, 213-231. Washington, 1875. Notes of dredging on the Brazilian coast, 214-215.

PRAGUER, HFNRIQUE: Riqueza mineral do Estado da Bahia, I, II, III. Formação geologica do Estado da Bahia, mineraes existentes, explorações antigas e modernas. Revista Trimensal do Instituto Geographico $e$ His. torico da Bahia, Anno IV, Vol. IV, No. 131, 419-431. Bahia, Setembro, 1897.

IV, formação geologica da cidade da Bahia e seus arredores.

$\mathrm{V}$, Ilha de Itaparica.

VI. terrenos de Massapé de Santo Amaro.

VII, de Alagoinhas para o Rio S. Francisco. Anno V, Vol. V, No. 15, 81106. Bahia, Março, 1898.

VIII, O. diamante, 57-68. Anno VI, Vol. VI, No. 19. Bahia, Março, 1899. Partes LII e LIII forão publicadas tambem na Revista Industrial de Minas Geraes. Anno V, No. 32, 30 de Novembro de 1897, 97 (bis)-100. Ouro Preto, 1897.

PRAGUER, HENRIQUE: Annexo 1 do relatorio do Dr. Alfredo de Britto "sobre as areias do Prado," 57-67. Dated Bahia, Sept. 23, 1896. Bahia, 1898.

PRAGUFR, HENRIQUE: Maravilhas de natureza. Diario da Bahia, Bahia, Dez. 12, 1902. Jornal do Commercio, Rio de Janeiro, Dez. 30, 1902.

PRAGUER, H.: The diamond fields of Bahia, Brazil. Brazilian Mining Review, I, 32-33. Ouro Preto, 1902.

PRAGUER, H.: (On the ages of the Bahia sediments.) Brazilian Mining Review, I, 112. Rio de Janeiro, Jul., 1903.

PRAGUER, H.: O parcel dos Abrolhos. Boletim ala Secretaria da Agricultur etc. do Estado da Bahia, II, No. III, 218-221. Bahia, 1903.

PRATES, CARLOS, e GUIMARÃES, ARTHUR: Empresa de mineração do Caethê. Revista Industrial de Minas Geraes, No. 1, 17-20. Ouro Preto, 15 de Outubro de 1893.

PRATES, CARLOS: Analyse de quartzito da "Venda do Campo," municipio de Ouro Preto. Revista Industrial de Minas Geraes, Anno I, No. 1, 20. Ouro Preto, Outubro de 1893.

PRATES, CARLOS: Salitre do valle do Rio das Velhas. Revista Industrial de Minas Geraes, Anno I, No. 10, 15 de Julho de 1894, 246-248; No. 11, 15 de Agosto de 1894, 275-277. Ouro Preto, 1894.

PRATFS, CARLOS: Jazida aurifera de Marzagão. Revista Industrial de Minas Geraes, Anno I, No. 4, 77-80. Ouro Preto, 15 de Janeiro de 1894.

PRIOR, G. T.: $\nabla$. HUSSAK and PRIOR.

PRIOR, G. T.: Note on the occurrence of rocks allied to Monchiquite in the Island of Fernando de Noronha. Mineralogical Magazine and Jour. Min. Soc., XI, No. 52, 171-175. London, 1897. Reprint, pp. 1-5.

PRIOR, G. T.: On the chemical composition of Zirkelite. Mineral. Mag. and Jour. Mineral. Soc., XI, May, 1897, 180-183. London, 1897. Abstract: Neues Jahrbuch fïr Mineral., 1898, II, 196. Referate.

PRIOR, G. T.: Petrographical notes on the rock specimens collected in the little island of Trinidad, S. Atlantic, by the Antarctic Expedition of 18391843 under Sir James Clark Ross. Mineralogical Magazine, Nov., 1900, No. 58, XII, 317-323. Iondon, 1900.

PRZFWODOWSKI, ANDRE: Duas palavras sobre os terrenos entre a cidade da Bahia e o Joazeiro, considerados geologicamente. (Dated 18 de Março de 1848.) Revista do Instituto Historico, X (2a edição), 384-386. Rlo de Janeiro, 1870 (for 1848). Extract: Diccionario geographico aas Minas do Brazil. Por Franco Ignacio Ferreira. 243-244. Rio de Janeiro, 1885.

QUATRFFAGES, DE: I'homine fossile de Lagôa Santa, au Brésil et ses descendants actuels. Izvyestiya imp. obshchestva Luibitelel Hstestvoznaniya. Antropologhel i etnografi, $4^{\circ}$, XXXV, 321-338. Moscow, 1880 and 1882. 
Separate from the Comptes Rendus au Congres d'Anthropologic, $4^{\circ}, 17$ pages. Moscow, 1881. Abstract: La Nature, $\mathrm{X}$ annee, 16. Paris, 1882.

QUATRFFAGES, DE: L'homme fossile de Lagôa-Santa (Brésil) et ses descendants actuels. (Extract from les actes du Congrès Anthropologique de Moscou, 1879. Moscow, 1880 . Comptes Rendus de l'Acad. des Sci., 1881, XCIII, 882-884. Separate, $4^{\circ}, 19$ pp. Paris, 1881.

QUATREFAGES, DE: Note sur l'état des sciences naturelles et de l'anthropologie au Brésil. Comptes Rendus de l'Acad. des Sci., XOVI, 308-313. $4^{\circ}$. Paris, 1883.

QUATREFAGES: Récherches sur les populations actuelles et prè-historiques de Brésil. (Archives du Musée National de Rio de Janeiro, VI.) Comptes Rendus de l'Acad. Sci., CI, 467-470. 4. Paris, 1885.

RABELLO, CARLOS NUNES: Relatorio dos trabalhos durante a campanha de 1895, pp. 127-130 do Relatorio apresentado ao Dr. Secretario de Estado da Agricultura do Estado de Minas Geraes pelo Inspector de Terras e Colonizaçẫo, Dr. Carlos Prates em 1896. Ouro Preto, 1896. Annexo A : Relatorio da Commissão Geographica e Geologica.

RABELLO, CARLOS N.: Serra da Treituba, Minas Geraes. Revista Industrial de Minas Geraes. Anno V, No. 29, 57-58. Ouro Preto, 30 de Outubro, 1897.

RABELLO, CARLOS N.: Noticia sobre a Commissão Geographica e Geologica do Estado de Minas. Revista Industrial de Minas Geraes. Anno $\nabla$, No. 25, 4-5. Ouro Preto, 20 de Junho, 1897.

RABELIO, CARLOS NUNES: (Explorações de 1896.) Annexo A, pp. 15-17 do Relatorio apresentado ao Dr. Secretario de Estado de Agricultura do Estado de Minas Geraes pelo Inspector de Terras e Colonização, Dr. Carlos Prates em 1897. Ouro Preto, 1897.

RABELLO, CARLOS NUNES: A Serra de São Thome das Lettras. Annuario da Escola Polytechnica de São Paulo. Anno IV, 59-62. São Paulo, 1903.

RAMMELSBERG, O. F.: Das Tellurwismuth von S. Jose in Brasilien. (Analysis.) Gelehrte Anzeigen, part I, No. 106, 854. München, 1846.

RATH, CARLOS: Fragmentos geologicos e geographicos, etc., para a parte physica da estatistica das Provincias de S. Paulo e Parana. Exploradas a proprias expensas do autor, começados no anno de $1845 .{ }^{*} * * 8^{\circ}, 78$ pp. S. Paulo, 1856.

RATH, CARLOS: Noticla ethnologica sobre um povo que já habitou a costa do Brasil, bem como o seu interior, antes do diluvio universal. Revista do Inst. Hist., XXXIV, 287-292. Rio de Janeiro, 1871.

RATH, OARLOS JOSE FREDERICO: Algumas palavras ethnologicas e paleonthologicas a respeito da provincla de S. Paulo. $4^{\circ}, 30 \mathrm{pp}$. Rlo de Janeiro, 1875.

RATH, G. VOM: (Chalcedony concretions.) Verhandlungen des Naturhistorischen Vereins der preussischen Rheinlande und Westfalens, XXXII, 203. Sitzungswerichts. Bonn, 1875. Abstract: The Geological Record for 1875, 254. London, 1877.

RATH, G. VOM: Ueber einen merkwürdigen pseudomorphen Kalkspath-Zwilling aus Brasilien. Zeitschrift fïr Krystallographie und Mineralogie (Groth), II, 187-189. Leipzig, 1878.

RATH, G. VOM: Naturwissenscahftliche Studien Erinnerungen an die Pariser Welt-ausstelung 1878. Von Professor G. vom Rath, K. Geheimer Bergrath. Bonn, 1879. Diamanten, 391-399.

RATH, KARL: Die Sambaquis oder Muschelhügelgräber Brasillens. Globus, XXVI, No. 13, 193-198, 214-218. Ill. Braunschweig, 1874.

RATHBUN, MARY J.: (Description of a new species of Zanthopsis from Parahyba do Norte.) Bul. Geol. Soc. Amer., XIII, 43-44, plate. Rochester, 1902. 
RATHBUN, RICHARD: On the Devonian Brachiopoda of Erere, Province of Para, Brazil. Bulletin Buffalo Society of Nat. Sci., I, 236-261. Buffalo, 1874. Abstract: $O$ Novo Mundo, Abril 23, 1874, IV, 128. N. Y., 1874. Notice: Verhandlungen du K. K. geologischen Reichsanstalt. Jahrg., 1880, 117-118. Wien, 1880. Abstract: Geological Record for 1874, 319. London, 1875.

RATHBUN, RICHARD: Preliminary report on the Cretaceous Lamellibranchs collected in the vicinity of Pernambuco, Brazil, on the Morgan Expedition of 1870, Ch. F. Hartt in charge. Proc. Boston Soc. Nat. Hist., XVII, 241256. Boston, 1875.

RATHBUN, RTCHARD: Extinct coral reef at Bahia. American Naturalist, $\mathrm{X}$, 439-440. Boston, 1876.

RATHEUN, R.: Sketch of Professor C. F. Hartt. Popular Science Monthly, XIII, 231-235. New York, June, 1878. (Portrait on p. 129.)

RATHBUN, RICHARD: Sketch of the life and scientific work of Professor Charles Fred. Hartt. Proc. Boston Soc. Nat. Hist., XIX, 338-364. Boston, 1878.

RATHBUN, RICHARD: Observações sobre a geologia. Aspecto da Ilha de Itaparica na Bahia de Todos os Santos. Archivos do Museu Nacional, 111, 159-183. Rio de Janeiro, 1878.

RATHBUN, R.: Brazilian corals and coral reefs. American Naturalist, Sept., 1879, XIII, 539-551, ill. Philadelphia, 1879.

RATHBUN, RICHARD: Notes on the coral reefs of the Island of Itaparica, Bahia, and of Parahyba do Norte. Amer. Jour. Sci., CXVII, 326-327. New Haven, 1879. Proc. Boston Soc. Nat. Hist., XX, May, 1878, 39-41. Boston, 1881.

RATHBUN, RICHARD: Professor Hartt on the Brazilian sandstone reefs. American Naturalist, XIII, 347-358. Philadelphia, 1879.

RATHBUN, RICHARD: Notice of recent scientific publications in Brazil. $O$. A. Derby on the geology of the Lower Amazonas. Amer. Jour. Sci., CXVII, 464-468. New Haven, 1879.

RAthbUN, R.: The Devonian Brachiopoda of the Province of Para, Brazil. Proc. Boston Soc. Nat. Hist., XX, 14-39. Boston, 1881.

RATIRAY, AIFXANDER: On the geology of Fernando de Noronba. Quart. Jour. Geol. Soc., Nov., 1871, XXVIII, 31-34. London, 1872.

RATTRAY, AIEXANDER: A visit to Fernando de Noronha. Jour. Roy. Geogr. Soc., XLII, 431-437. London, 1872.

RAYMOND, R. W.: See Mezger, $A$.

RAYMOND, R. W.: (Structure of augengneiss at Rio de Janeiro.) Trans. Amer. Inst. Min. Engs., XXV, 1036-1040. New York, 1895.

READE, T. MEITARD: Denudation of the two Americas. American Journal of Science, XXIX, No. 172, 290-300. New Haven, 1885. Same in Proceedings of the Liverpool Geological Society, V, 8-41. Liverpool, 1889. (Amazonas, 22-25.)

READE, T. MELTARD: The exfoliation of gneiss in Brazil. Geological Magazine Decade IV, vol. IV, 130-132. London, 1897. Abstract: Neues Jahrb. f. Mineral., 1897, II, 472 . Referate.

READE, T. MEILARD: The Amazons. (A portion of the paper on Denudation of the two Americas, reprinted in) "The evolution of earth structure, with a theory of geomorphic changes," 266-269. London, New York, and Chicago, 1903.

REAY, JR., W.: Mining explorations in Brazil. The Province of Parahyba and Pernambuco (written from Minas de Cachoeira, Pianco, Parahyba). The Mining Journal, Feb. 13, 1864, XXXIV, 106. London, 1864.

REBEIIO, DOMINGOS JOSE ANTONIO: Corographia ou abreviada historia geographica do Imperio do Brasil, coordinada, acrescentada, e dedicada a Casa Pia, e Collegio dos Orfãos de $\mathbf{S}$. Joaquim desta cidade, etc. $8^{\circ}$. Bahia, 1829. Mineralogia, 34-35, 207, 223, 233. 
RECHSTFINFR, GASPAR: Carvão de pedra (do Rio Grande do Sul). Carta ao Presidente da Provincia sobre a qualidade e quantidade. Auxiliador da Industria Nacional, No. 11, L, 255-256. Rio de Janeiro, Nov., 1882.

RECIUS, EIISEE: Nouvelle Géographie universelle. La terre et les Hommes, XIX. Amérique du Sud. l'Amazonie et la Plata. Paris, 1894. Brésil, 91495. Industrie minière, $465-470$.

REDWOOD, BOVERTON, and TOPLEY, WILIIAM: Report on the Rlachodoce and Camarajibe shale deposits on the coast of Brazll near Maceio. $8^{\circ}, 12$ pp. and maps. (London, 1891.)

REES, ABRAFAM: The Cyclopodia or universal dictionary of arts, sciences and literature. Article on Brazil in V, 4 pp. (not numbered). London, 1819. Contains notes on the gold and diamond mines.

REGEI, F.: Die geologische Entwicklung des unteren Amazonasgeblets nach Fr. Katzer. Geographische Zeitschrift, X, 461-465. Leipzig, 1904.

REGO, FABIO HOSTILIO DE MORAES: $\nabla$. CAMPOS, IUIZ F. GONZAGA DE.

REICHENBACK, F. STROMER VON: Observations sur l'histoire geologique de l'Ethiopie. (Zeitschrift d. Deutsch. Geolog. Gesellsch., LIII, Heft 4, 1901), XVI, 153-154. Bruxelles, 1902.

REIMANN, GUSTAV: Beiträge zur Kenntnis des Turmalins aus Brasillen. Von Gustar Reimann aus Lüibeck. Neues Jahrb. f. Min. XXIII. BeilageBand, mit Taf. IV-VI. 91-162. Stuttgart, Januar, 1907.

REINDE, JOSEF: Die schwazen Fluesse Sudamerikas. Hydrographische Studie auf geologischorographischer, physikalischer und biologischer Grundlage. Münchener geographische Studien. 13es Stiick. 138 pp., 1 map. München, 1903.

REINHARDT, PROFESSOR: Bone caves of Brazil and their animal remains. The Geological Magazine, May, 1868, V, 227-228. Amer. Jour. Sci., 1868, XCVI, 264-265. New Haven, 1868. Translated from Tidschrift for populare Fremstillinger af Naturenideskaben, udgtiet af C. Togh az C. Lüken, 1867. Annual of Scientific Discovery for 1869, 259-260. Boston, 1869 . Abstract: The Popular Science Review, VII, 319-320. London, 1868.

REINHARDT, J.: De 1 Brasilienske Knoglehuler fundae Glyptodon levinger og en ny, til de gravigrade Edentater hörende slægt. [Remains of Glyptodon found in the bone-caves of Brasil and a new genus of Edentata.] Oversigt over Kongl. Vid. Selsk. Sker. Kjöbenhavn, 1877.

REINHARDT, J.: Kæmpedovendyr-Slægten Colodon. (The giant sloth Oolodon.) Oversigt over det Kongl. Danske Vid. Selsk. Skr., XII, No. 3, 257334, 5 plates. Resumé in French, 335-349. Kjöbenhavn, 1878 (vol. d. 1880). Abstract: The Geological Record for 1878, 305. Iondon, 1882.

REINHARDT, J.: De brasilianske Knoglehuler og do i dem forekommende Dyrelevninger. E M useo Lundii (v. Lütken), $4^{\circ}$, ill. I. Paper I, 1-56. Kjöbenhavn, 1888.

REINOEHL, GUSTAVO: Informe sobre el terreno minero cerca de Coxim en el Departamento de Corumba, Matto Grosso, Brazil. Buenos Aires (date ?), 45 pp., 2 maps.

REIS: See Batalha-Reis.

REISS, W.: Sinken die Anden? Aus den Verhandlungen der Gesellschaft für Erdkunde zu Berlin, 1880, No. 1, $8^{\circ}, 12$ pp. Berlin, 1880. Notes on the east coast of South America.

REITINGER, J.: See Hussak, $E$.

REITINGER, J.: Analytische Untersuchungen über d. naturl. Phosphate der Cerit- u. Yttererden, sowle über Zircon- u. Titanmineralien. InauguralDissertation d. k. technisch. Hochschule i München, März, 1902. 66 pp.

RENARD, A.: Notice sur les roches de l'ile de Fernando de Noronha, recuelliles pendant l'expedition du "Challenger." Bull. de l'Acad. Royale de Belgique, 3me série, III, 352-361, N. 4, 1 plate. Separate, Bruxelles, 1882. 
RENARD, A.: On some rock specimens from the Islands of the Fernando de Noronha group. Geological Magazine, III, 33. London, 1886. Also Report British Assoc. Adv. Sci. (Aberdeen), 1885, Sec. C, p. 1031. London, 1886.

RENARD, A.: Report on the rock specimens collected on oceanic islands during the voyage of $H$. M. S. Challenger during the years 1873-1876. The Voyage of $\mathrm{H}$. M. S. Challenger. Physies and Chemistry, II, $4^{\circ}$. London, 1889. Rocks of Fernando de Noronha, pp. 29-39 of the Petrographical part.

RENARD, A. F.: See Darwin, $C$.

RENAULT, B.: Sur une nouvelle Lycopodiacée houillére (Lycopoiopsis derbeyi). Note de M. B. Renault, presentée par M. Duchartre. Comptes Rendus de l'Acad. Sci., 1890, CX, 809-811. Paris, 1890. Fossil plants from Piracicaba, s. Paulo.

RENAULT, B.: Notice sur une Lycopodiacée arborescente du terrain houiller du Brếsil. Bul. Soc. Hist. Nat. d'Autun., III, 109-124, plate IX. Autun, 1890. Abstract in Notice sur les travaux scientifiques de M. B. Renault, 34-35. Autun, 1896.

RENAULT, B.: (Nota sobre fosseis carboniferos ou permianos de Piracicaba, S. Paulo.) Revista de Engenharia, No. 235, 14 de junro de 1890 . XII, 134. Rio de Janeiro, 1890. Abstract of the paper in Comptes Rendus, 1890, CX, 809-811.

REPSOLD, J. GEORG: Die Mangues von Santos. Mittheilungen der Geographischen Gesellschaft in Hamburg, 1876-77, 29-38, $8^{\circ}$. Hamburg, 1878.

RETTINGER, J.: $\nabla$. KRAUS, E. H.

RETUMBA, FRANCISCO SOARES DA SILVA: Relatorio que o Engenhelro de Minas Francisco Soares da Silva Retumba dirigio ao Exm. Sr. Dr. Antonio Herculano de Souza Bandeira, Presidente da Parahyba. 16mo, 46 pp. Pernambuco, 1896 . Few geological notes.

REZENDE COSTA, JOSE DE: Memoria historica sobre os diamantes, seu descobrimento, contractos e administração por conta da real fazenda: nodo de os avaliar, estabelecimento da fabrica de lapidação; sua extracç̃̃o e estado presente no Brazil. $4^{\circ}, 38$ pp. Rio de Janeiro, 1836.

REVISTA INDUSTRIAL DE MINAS GERAES: v. MEDRADO, A.

REVY, J. J.: Relatorio da Commisão de Açudes dirigido a S. Ex. o Sr. Conselheiro Manoel Buarque de Macedo, ... . sobre o reservatorio de Lavras e o Valle do Jaguaribe. $8^{\circ}, 42$ pp. Rio de Janeiro, 1881. Notes on the geology of Ceará.

RIBEIRO, JOSA DE ARAUJO RIBEIRO, VISCONDE DO RIO GRANDE: O fim da creação ou a natureza interpretada pelo senso commum, $657 \mathrm{pp}$. Rio de Janeiro, 1875. Published anonymously. Chiefly philosophical, but containing observations upon the geology of Brazil.

RICCOUs: Le Bougainville de la jeunesse ou nouvel abrege des voyages dans l'Amérique. Contenant la description des mours et coutumes des peuples de ce continent et les aventures des voyageurs qui l'ont parcouru ; * * * extraits des voyages de Bougainville, Cook, le pere Labat e autres voyageurs celèbrées, in-8 ${ }^{\circ}$ IV, $364 \mathrm{pp}$. Paris, 1828. Mines d'or et de diamants, etc., du Brésil.

RICHARDS, J. THOMAS: Notes on the iron ore deposits of Brazil. The Mining Journal, Railway and Commercial Gazette, LXXII, 253. London, Feb. 22, 1902. 12 chemical analyses of iron ores and one of slag.

RICHARDS, J.: Nota sobra installações ... da companhia, etc. Boletim Directoria da Agricultura da Bahia, VIII, 56-67. Bahia, 1906. Abstract: Brazilian Engineering and Mining Review, III, 185-186. Rio de Janeiro, Dec., 1906.

RICHARDSON, C. S.: Mining in Brazll. Engineering and Mining Journal, LXXX. 1221-1222. New York, Dec. 30, 1905. 
RICHARDsoN, J. W.: The Espirito Santo and Bahia monazite beds. Brazilian Mining Review, ill., I, 79-84. Rio de Janeiro, July, 1903.

RIDLET, H. N.: (Notes on the geology of Fernando de Noronha) quoted in Thomas Davies' Geology (of Fernando de Noronha), p. 90 of The Natural History of the Island of Fernando de Noronha based on the collection made by the British Museum Expedition in 1887, from the Journal of the Linnean Society (London), 1890. Linn. Soc. Jour., Bot., XXVII.

RIDLEY, HENRY N.: The raised reefs of Fernando de Noronha. Amer. Jour. Sci., 3rd series, XLI (CXLI), 406-409. New Haven, 1891.

RIGGS, R. B.: (Analysis of tourmaline from Calhao, Minas Geraes, Brazil.) Bul. 55 U. S. Geol. Sur., 25-26, 30, 32, 35. Washington, 1889. Abstract: Zeitschrift für Krystallog. und Mineralog. (Groth's), XV, 437. Leipzig. 1889.

RIGGS, R. B.: (Analysis of tourmaline from Calhao Minas Geraes.) Bul. Nu. 220, U. S. G. S., 59, 62 . Washington, 1903.

RIO BRANCO, BARON DE: Album de vues du Brèsil, exécuté sous la direction de J. M. de Silva Paranhos, Baron de Rio Branco. $4^{\circ}$. Paris, 1889. Collection destiné a accompagner le texte de la seconde édition du Brésil de M. E. Levasseur.

RIO GRANDE, VISCONDE DE: v. RIBEIRO.

RIVOT: Analyse d'un diamant en masse amorphe et compacte provenant du Brésil. Annales des Mines, 4me série, XIV, 419-422. Paris, 1848.

BIVOT: Analyse d'un diamant carbonique provenant du Brésil. Comptes Rendus de l'Academie, XXVIII, 317-319. Paris, 1849.

RIZZINI, CARLOS MAGLIA: O manganez no Bahia. Boletim da Secretaria da Agricultura etc. do Estado da Bahia, II, No. 1, 49-53. Bahia, 1903.

ROBELliAZ, F.: Rapport sur les mines de Faria. Paris, 15 Octobre, 1893.

ROBELI.AZ, F.: v. CUMENGE, E.

ROBERTS, W. MILNOR: Relatorio sobre o reservatorio D. Pedro I1. Revista de Engenharia, II, No. 7, 111-112. Rio de Janeiro, 1880.

ROBERTS, W. MILNOR: The Pedregulho reservoirs. The Rio News, VII, No. 19, p. 1. Rio de Janeiro, July 5, 1880.

ROBERTS, W. MILNOR: Relatorio de W. Milnor Roberts, engenheiro Chefe da Commissão Hydraulica sobre o exame do Rio $\mathbf{S}$. Francisco desde o mar até a cachoeira de Pirapora feito em 1879-1880 (etc.). Rio de Janeiro, 1880. Mineral resources and physical features. Appendix on geology by O. A. Derby, q. v.

ROBERTS, W. MILNOR: Observations in Brazil. Journal of the Franklin Institute, CX, 324-331. Philadelphia, 1880.

ROBERTS, W. MILNOR: Note on the São Francisco River, Brazil. Proc. Inst. of Civil Engineers, LXI, 256-260. London, 1880. Also as separate of 7 pages. London, 1880 . Notes on physical features.

ROCHA, D.: Analyses feitas nos laboratorios de chemica e docemasia da Escola de Minas de Ouro Preto. Minerios de ferro. Annaes aa Escola de Minas de Ouro Preto, No. 2, 133-138. Ouro Preto, 1883. Revista de Engenharia, 14 de setembro de 1883, V, 239-240. Rio de Janeiro, 1883. Revista Industrial de Minas Geraes, Anno 1, N. 2, 46-47. Ouro Preto, 15 de Nov., 1893.

ROCHA, DOMINGos: See Sena, J. C. da Costa.

ROCHA PITTA, SEBASTIÃo DA: Historia da America portugueza desde o anno de mil e quinhentos do seu descobrimento, até o de mil e setecentos e vinte e quatro, etc. $4^{\circ}$. Lisboa occidental, 1730. Mines, 391, 491, 470, $493,602,642$.

RODRIGUES, J. BARBOSA: Les reptiles fossiles de la vallee de l'Amazon. Vellosia. Contribuiçóes do Museo Botanico do Amazonas, II, 41-56. 2a ed., Rio de Janeiro, 1892. ['The plates I to XV are in Vol. IV. Rio de Janeiro, 1891.] He names Purussaurus and says it is the largest river turtle yet discovered: See Gervais. 
RODRIGUES, JOSE CARLOS: A geologia no Brazil. O Novo Mundo, I1I, 67, (Editorial.) New York, Fevereiro 21, 1873.

ROFAN, HENRIQUE DE BEAUREPAIRE: A ilha de Fernando de Noronha. Considerações em relação ao estabelecimento de uma colonia agricolapenitenciaria. Pelo Brigadeiro Henrique de Beaurepaire Rohan. Typ. Universal, 1865. Annexo ao relatorio do Ministro da Guerra de 1865. Rio de Janelro, 1866.

ROSE, G.: Ueber das Verhalten des Diamants und Graphits bel Erhitzung Aus den Monatsberrd. Akad. 1872, Juni. Pogg. Annalen der Phys. u. Chemie, CXLVIII, 497-524. Leipzig, 1873. Der sogenannte Carbonado oder carbonat, 517.

ROSE, G.: Bemerkungen zur vorstehenden Abhandlung. [ie Ueber die wahre Lagerstätte der Diamanten und anderer Edelsteine in der Provinz Minas Geraes in Brasilien von Ch. Heusser u. G. Claraz.] Zeitschrift der Deutschen Geologischen Gesellschaft, XI, 467-472. Berlin, 1859.

ROSENBUSCH, H.: Mineralische und geognostische Notitzen von einer Reise in Süd-Brasilien. Separatabdruck aus den Berichten der naturforschenden Gesellschaft zu Freiburg in Breisgau. $8^{\circ}, 39$ pp. and plate. Freiburg (i. B.), 1870. Abstract : Neues Jahrbuch für Mineral., 1871, 84-85.

ROSENBUSCH, H.: Das Eisenerz-Lager von S. João d'Ypanema in Brasillen und das Vorkommen des Martit. Mineralogische $u$. geognost. Notizen von einer Reise in Südbrasilien. Freiburg, 1870. Abstract: Neues Jahrbuch fïr Mineral., 1871, 78-79.

ROSENBUSCH, H.: Mikroskopische Physiographie der Mineralien und Gesteine. Ein Hülf́sbuch bei mikroskopischen. Gesteinsstudien. Band II, Massige Gesteine. Zweite ganzlich umgearbeitete Auflage. $8^{\circ}, 877+\mathrm{XV}$. Stuttgart, 1887. Many references to Brazilian rocks and minerals. Also edition of 1895 . 114, 119, 120, 124, 146, 155, 158, 161, 168, 179, 180, 191, $192,198,245-247,432,434,465,470,480,481,486,530,537,540,819,1075$, $1233,1239$.

ROSENBUSCH, H., and HUNTER, M.: On Monchiquite, a Camptonitic volcanlc equivalent of Elæolite-syenite. Mineralogische und Petrographische Mittheilungen, XI, 445-466. Wien, 1890. Abstract in Mineral. Mag. and Jour. Mineral. Soc., March, 1893, X, 177-178.

RöSLER, H.: Ueber Hussakit (Xenotim) und einige andere seltene gesteinsbildende Mineralien. Zeitschrift für Krystallographie, XXXVI, 258-267. Leipzig, 1902.

ROSS, CAPT. JAMES OLARK: A voyage of discovery and research in the southern and antarctic regions during the years $1839-43$. 2 vols., $8^{\circ}$, tll. London, 1847. Notes on the volcanic nature of Trinidade, I, 22.

BOSS, J.: The minerals of Brazil. Engineering and Mining Journal, LIX, 125126. New York, 1895. Abstract: Journal of the Iron and steel Institute, XLVII, 321. London, 1895.

ROSWAC, C.: Les métaux précieux considérés au point de vue économique. Paris, 1865. Brazil, 93-94.

ROTH: Ueber Krystallen des Amazonenstromes. $8^{\circ}$ Bonn, 1876.

ROTHWELL, RICHARD P.: The Mineral Industry, its statistics, technology and trade, in the United States and other countries to the end of 1898. VII, carbonados, 275-276 ; gold, 288, 304 ; manganese, 500 ; monazite, 518519. New York and London, 1899.

ROUSSIN, BARON: Le pilote du Brésil, ou description des côtes de l'Amérique méridionale, comprises entre l'ile Santa-Catarina et celle de Maranão etc. $8^{\circ}, 241 \mathrm{pp}$. Paris, 182\%. Notes on the reefs and physical features of the coast.

RUSSELL, ISRAEL C.: Criteria relating to massive-solid volcanic eruptions. Amer. Jour. Sci., 1904, CLXYII, 253-268, ill. Peak of Fernando de Noronha-theory of its origin. 
SA, FRANCIsco: Riquezas mineraes do Estado de Minas Geraes. Relatorio apresentado ao Dr. Presidente do Estado de Minas Geraes pelo Secretario de Estado dos Negocios da Agricultura, Commercio e Obras Publicas em o anno de 1895, 322-326. Ouro Preto, 1895.

BAINT-ANDRE, DURAND DE: Sur l'existence de terrains auriferes dans la province de Fernambouc, Brésil. Annales des Mines, 5me série, VII, 604. Paris, 1855.

BAINT-HIrAIRE, A. DE: Notice sommaire des voyages de M. Auguste de Saint-Hilaire dans le Brésil, la province Cisplatine et les missions du Paraguay. Nouv. Ann. des Voyages, XVII, 228-236. Paris, 1823.

BATNT-HILAIRE, AUGUSTE DE: La Serra da Lapa, portion de la grande chaine occidentale du Brésil. Nouv. Ann. des Voyages, XLVII, 99-100. Paris, 1830.

SAINT-HILAIRE, AUGUSTE DE: Voyage dans les provinces de Rlo de Janeiro et de Minas Geraes, 2 vols., $8^{\circ}$. Tome $1 \mathrm{er}, \mathrm{XVI}+458$; II, VI +487 . Paris, 1830. Notes on the mines and the geology. Review: Nouvelles Annales des Voyages, L, 65-97. Paris, 1831.

BAINT-HILAIRE, AUG. DE: Voyage dans l'Interieur du Brésll. $8^{\circ}, 2$ vols. Ixelles lez Bruxelles, 1850. (I, 212 pp., ill.; II, 208 pp.) Tome I, chap. III-IV, Excursion dans la province des mines; chap. V, Exploitation des mines d'or; ehap. VI, voyage a Itabira; VII, mines de fer. [Possibly this is an abridgment of the preceding title.1

SAINT-HILAIRE, AUGUSTE DE: Voyage dans le district des diamans et sur le littoral du Bresil, suivi de notes sur quelques plantes caractéristiques, et d'un précis de l'histolre des revolutions de l'empire bresilien, depuis le commencement du règne de Jean VI jusq'a l'abdication de D. Pedro, 2 vols., 12mo. Vol. I, $\mathrm{XX}+402$; vol. II, 456 pages. Paris, 1833 . Analyse, Nouv. Ann. des Voyages, LXIII, 81-91. Paris, 1834. Revlew under the title "The diamond districts of Brazil," Westminster Review, XXI, 297-319. London, Oct., 1834.

SAINT-HILAIRE, AUGUSTE DE: Province de S. Pedro de Rio Grande do Sul. Nouv. Ann. des Voyages, LVII, 236-257. Paris, 1833.

SAINT-HILAIRE, AUG. DE: Les sources du Rio de S. Francisco. Nouv. Ann. des Voyages, XCV, 171-186. Paris (1842).

SAINT-HILAIRE, AUGUSTE DE: Yoyage aux sources du Rio de S. Francisco et dans la Province de Goyaz. I, pp. XV + 378. Paris, 1847. II, 349. Paris, 1848. (Notes on the physical features and geology.) Review: Nowvelles Annales des Voyages, CXXI, 89-108, 326-345. Parls (1849).

SAINT-HILAIRE, AUGUSTE DE: Observations sur les diviseurs des eaux de plusieurs des grandes rivières de l'Amérique du Sud, et sur les noms qu'll convient de leur appliquer. Nouv. Ann. des Voyages, GXVI, 257-271. Paris, 1847. Comptes Rendus de l'Acad. Sci., XXV, 645-650. Paris, 1847.

SAINT-HILAIRE, AUGUSTE DE: Voyage dans les Provinces de Saint-Paul et de Sainte-Gathérine. 2 vols., $8^{\circ}$. Vol. I, VI +464 pp.; vol. II, 424 . Paris, 1851. Occasional notes on the geology and physical features.

ST. JOHN D'EL REY: Annual reports of the directors of the St. John d'el Rey Mining Company, London, May 5, 1831, to 1904. These reports by many authors contain valuable observations regarding the geology of the several gold mining properties controlled by that company in the State of Minas Geraes.

ST. JOHN D'EL REY: St. John d'el Rey Mining Co. The Mining Journal, Railvoay and Commercial Gazette, LVII, 10. London, Jan. 1, 1887.

ST. JOFN D'EL REY: Abstracts of official reports of St. John d'el Rey MinIng Company, Brasil. Engineering and Mining Journal, LXVIII, 431. New York, 1899.

SALDANHA DA GAMA FILHO, JOSE DE: Parecer sobre o trabalho do Sr. Conde de la Hure. Revista do Instituto Historico, XXIX (pt. II), 417421. Rlo de Janelro, 1866. 
SALDANHA DA GAMA, JOSE DE: Cinco lições de geologia, senđo duas sobre paleontologia vegetal, pronunciadas no anno de 1868 na cadeira do 58 anno da Escola Central. $8^{\circ}, 77$. Rio. 1872.

SAIVADOR, FREY VICENTE DO: Historia do Brazil. Escripta na Bahla a 20 de Dezembro do 1627. Annaes da Bibliotheca Nacional ao Rio de Janeiro, XIII. Das minas de metaes e pedras preciosas do Brazil, 11-12. Rio de Janeiro, 1888.

SALVADOR, FREY VICENTE DO: Historia do Brasil . . . escripta na Bahia a 20 de Dez. 1627. Das minas de metaes e pedras preciosas do Brasil. Annaes da Bibliotheca Nac. do Rio de Janeiro, XIII, 11-12. Rio de Janeiro, 1889.

SAMPAIO, MARCIANO: The Nazareth manganese deposits, Bahia. Brazilian Mining Review, I, 182-183. Rio de Janeiro, March, 1904.

SAMPAIO, THEODORO FERNANDES: Informaç̃es a respeito dos caracteres geologicos do terreno comprehendido entre a cidade de Alagoinhas e a do Jonzeiro pelo trajecto da linha ferrea em construcção. Revista de Finyenharia, Mar. 14, 1884, IV, 52-54. Rio de Janeiro, 1884.

SAMPAIO, THEODORO: Consideracões geographicas e economicas sobre o Valle do Rio Paranapanema. Boletim da Commissão Geog. e Geol. do Estado de S. Paullo, $1890 . \quad$ No. 4, 44 pp., $8^{\circ}$. S. Paulo, 1890.

SAMPAIO, THEODORO: Campos de Jordão na Serra da Mantiqueira. Notas de viagem. $8^{\circ}, 28$ pp., com mappa. São Paulo, 1893.

SAMPAIO, THEODORO: Noticia sobre o local da projectada cidade de $\mathbf{S}$. Francisco dos Campos na parte norte dos Campos de Jordão. $8^{\circ}, 24$ pp. com mappa. São Paulo, 1895.

SAMPAIO, THEODORO FERNANDFs: Carta do Reconcavo da Bahia gravada mediante auxilio do Governo do Estado na administração do Exmo. Sr. Cons. Luiz Vianna, Escala 1 to 250,000. Bahia, 1899. Notas sobre a geologia.

SAMPaIo, Theodoro: $O$ Rio de $\mathrm{S}$. Francisco (Trechos de um diario de viagem) Santa Cruz. (Pequena Revista de Religião, Letras, Artes e Pedagogia por un grupo de amigos do Lyceu do Sagrado Coração de Jesus.) I $54,120,149,180,200,256,283,314$; II, 11, 41, 103, 127. São Paulo, 1900-190 (?).

SANFORD, FANCHON: $\nabla$. DIEULAFAIT.

SANTA-ANNA: V. NERY, F. J. DE STA. ANNA.

SANTOS, JOAQUIM FELICIO DOS: Memorias do Districto Diamantino da Comarca do Serro Frio, Provincia de Minas Geraes. $8^{\circ}, 438$ pp. Rlo de Janeiro, 1868.

SANTOS, JOSE AMERICo DOS: Cal de marisco, Revista de Engenharia, Anno II, No. 1, 4-7. Rio de Janeiro, 15 de Jan., 1880. Revista Industrial, Novembro de 1879, V, 137-138. (Dated 11 de Agosto de 1879.) New York, 1879. Shell deposits about Rio de Janeiro.

SANTOS, JOSE AMERICo DOS: (Os relatorios sobre os reservatorios do Rio de Janeiro.) Revista de Engenharia, II, No. 7, 105-108, $4^{\circ}$. Rio de Janeiro, 1880.

SANTOS, JOSE AMERICo DOS: Minas de carvão de pedra do Arrolo dos Ratos. Revista de Engenharia, V, 230. Rio de Janeiro, 28 de Agosto, 1883.

SANTOS, JOSE AMERICo Dos: Minas de carvão do Arrolo dos Ratos na Provincia do Rio Grande do Sul. Revista de Engenharia, V, 259-260. Rio de Janeiro, 28 de Set., 1883. Tests and general geology of the coal.

SANTOS, JOSE AMERICo DOS: A Commissito Geographica e Geologica de S. Paulo. Revista de Engenharia, No. 166, IX, 167. Rio de Janeiro, 28 de julho, 1887.

SANTOS, JOSE AMERICO DOS: Poco artesiano (no Ceara). Revista de Engenharia, No. 211, XI, 131. Rio de Janeiro, 14 de Junho, 1889. 
SANTOS, DR. JOS AMERICO DOS: A commissão geographica e geologica (de S. Paulo). Revista de Engenharia. No. 205, XI, 60. Rio de Janeiro, 1889.

SANTOS, JOSE AMERICo DOS: (Hosseis colligidos por Joseph Mawson na Bahia.) Revista de Engenharia, No. 203, XI, 36. Rio de Janeiro, 14 de Fev., 1889.

SANTOS, JOSE AMERICO DOS: Fosseis Devonianos de Matto Grosso. Revista de Engenharia, No. 239, XII, 188. Rio de Janelro, 14 de Agosto, 1890.

SAO LEOPOIDO, VISCONDE DE: V. PINHEIRO.

SARMENTO, JACOB DE CASTRO: Historical accounts of the discovery of gold and diamonds in Minas Geraes, Brazil. Materia Medica physico-historicomechanica, Reyno Mineral, Pt. 1, 120. London, 1735 . Gold, 9-14; diamonds, 149-154; crystal, 192-193 pedra-iman. 196. Sobre as Minas d'ouro e diamantes do Brasil. Quoted in Boubê's Geologia Elementar, annexo, 40-42. Rio de Janeiro, 1846.

SAVARY: Rapport sur les resultats scientifiques du voyage de M. Alcide d'Orbygny dans l'Amérique du sud, penđant les années 1826 a 1833: Rapport sur la partie géographique du voyage de M. d'Orbigny. Nouvelles Annales du Muséum d'Histoire Naturelle, III, 105-107. Paris, 1894.

SAWKINS, J. G.: v. BROWN, C. B.

SAXE-COBURGO-GOTHA, PEDRO AUGUSTO DE: Présence de l'albite en cristaux, ainsi que de l'apatite et de la schéelite, dan les filons auriferes de Morro-Velho, province de Minas Gertes. Comptes Rendus de l'Acad. Sci., II (CV), 264-265. Paris, 1887. Abstract: Zeitschrift für Krystallographie, etc. (Groth), XIV, 604. Leipzig, 1888.

SAXF-COBURGO-GOTHA, PEDRO AUGUSTO DF: Breves considernçōes sobre mineralogia, geologia e industria mineira do Brazil. Conferencia realisada no Instituto Polytechnico Brazileiro a 7 de Nov. de 1888. 1a Parte 1o fasciculo, I-XI, 2o fasciculo, 2a edição, 1-28. Rio de Janeiro, 1889. Noticia : Revista de Engenharia, No. 215, XI, 171. Rio de Janeiro, 14 de Agosto de 1889.

SAXE-COBURGO-GOTHA, PEDRO AUGUSTO DE: Algumas palavras sobre quartzo no Brazil. Rio de Janeiro, 1889.

SAXE-COBURGO-GOTHA, PEDRo AUGUSTo DE: Sur l'albite de Morro Velho. Comptes Rendus de l'Acad. Sci., CVIII, 1070-1071. Paris, 1889. Abstract: Neues Jahrb. f. Mineral., 1890, II, 188 Referate. Abstract: Zeitschrift für Krystallographie und Mineralogie, XIX, 520. Leipzig, 1891.

SAXE-COBOURG-GOTHA, PEDRO AUGUSTO DE: Fer oligiste speculalre cristallisé de Bom Jesus dos Meiras, province de Bahia, Brésil. Comptes Rendus de l'Acad. Sci., CVIII, 1069-1070. Paris, 1889. Abstract: Neues Jahrb. f. Mineral., 1890, II, 188 Referate. Abstract: Zeitschrift für Krystallog. und Mineralog., XIX, 520. Leipzig, 1891.

SAXE-COBOURG-GOTHA, PEDRO AUGUSTO DE: Sur la millérite de MorroVelho, province de Minas Geraes, Brésil. Comptes Rendus de l'Acad. Sci., CXI, 1001-1002. Paris, 1890. Abstract: Neues Jahrb. f. Mineral., 1892, I, 30 Referate. Abstract: Zeitschrift für Krystallographie, XX, 638. Leipzig, 1892.

SAXE-COBURG, PEDRO AUGUSTO DE: Note du deuxième fascicule d'un ouvrage publié em langue portugaise, intitulê: "Breves considerações sobre mineralogia, geologia e industria mineira do Brazil." Comptes Rendus de l'Acad. Sci., CX, 978. Paris, 1890.

SACHSEN-COBOURG, DOM PEDRO AUGUSTO DE: Beiträge zur Mineralogie und Petrographie Braziliens. (Illus.) Mineralogische und Petrographische Mittheilungen, von G. Tschermak, N. F., X, 451-463, $8^{\circ}$. Vienna, 1889. Notice: Comptes Rendus de l'Acad. Sci., CX, 426. Paris, 1890. Abstract: Zeitschrift für Krystallographie und Mineralogie, XX, 295-296. Leipzig, 1892. 
SCHABUS: Ueber den Euklas von Brazilien. Denkschriften der $k . k$. alkademie $a$. Wissenschaft z. Wien, Vienna, 1854, VI, 57. Sitzungsberichte d. Akademie, Vienna, 1852, VIII, 507.

SOHÄFFER, RITTER VON: Brazilien als Unabhängiges, Reich in historischer, mercantilischer und politischer Beziehung, 464 pp., $8^{\circ}$. Altona, 1824 . Notes upon the mining regions, mineral products and physical features.

SOHANZ, M.: Das heutige Brasilien. Land, Leute, und wirtschaftliche Verhältnisse, 364 pp. Hamburg, 1893.

SCHERER, FRIEDRICH: Studien em Arsenkiese. Zeitschrift für Krystallographie und Mineralogie (Groth), XXI, 354-387. Leipzig, 1893. Macagão bei Sabará, Minas Geraes, 361-362, 380.

SOHICHTEL, CARL: Der Amazonen-Strom. Versuch einer Hydrographie des Amazonas gebeites auf orographische-meteorologischer Grundlage. Mit fünf Tafeln und Zweit Text-Abildungen. Geographische Dissertation (etc.) . $8^{\circ}, 117$ pp. Strassburg, 1893.

BOHOELLER, RICHARD: Natur und Beschaffenheit einiger Flusswasser aus dem Stromgebiet des Rio de la Plata. Berichte du Deutsch. Chem. Gesellch., XX, 1784-1788. Berlin, 1887. Includes analyses of Rio Negro and Uruguay waters.

SCHOMBURGK, R. H.: Journey from Fort San Joaquim, on the Rio Branco, to Roraima, and thence by the Rivers Parima and Merewari to Esmeralda, on the Orinoco, in 1838-9. Journal of the Royal Geographical Society, X, 191-247. London, 1841.

SCHOMBURck, R. H.: Journey from Esmeralda, on the Orinoco, to San Carlos and Moura, on the Rio Negro, and thence by Fort San Joaquim to Demerara, in the spring of 1839. Journal of the Royal Geographical Societ. $1, \mathbf{X}, \mathbf{2 4 8 - 2 6 7 . ~ I o n d o n , ~} 184$ ].

SCHRFIKERS, DR. VON: Ueber Natterer und Sochor in Brasilien. Nene Jahrbücher der Berg. u. Hüttenkunde (von Moll's), V, 415-416. Nürmberg, 1824.

SCHUBERT, FRED. M.: Memorial da Imperial Companhia Metallurgica do Assuru氏 e das Minas de Ouro do Gentio. Bahia, 1884.

SCHUCH, R.: Relação abreviada de algumas experiencias sobre a fabricucão de ferro corrido na provincia de Minas Geraes, fol., 8 pp. Rio de Janeiro, 1837.

SCHUCH, ROQUE: Memoria sobre algumas experiencias e empenhos mineralogicos e metallurgicos, $4^{\circ}, 53$ pp. Rio de Janeiro, 1840.

S. (SCHUCHFRT), C.: Review of "Ueber Untersilur in Venezuela." Amer. Jour. Sci., CLX'IX, 197-198. Feb., 1905.

SCAUCHERT, C.: The faunal provinces of the middle Devonic of America, ete. American Geologist, XXXII, 137-162. Sept., 1903. (Brazilian Devonian, 152-3.)

SCHUCHERT, CHARTFS: Geology of the Lower Amazon region. Joumal of Geology, XIV, 722-746. Chicago, Nov.-Dec., 1906.

SCHULTZ, WOLDEMAR: Historisch-geographisch-statistische Skizze der Kalserlich-brasilianischen Provinz Rio Grande do Sul. Nach officiallen Angaben und eigner Anschauung. Zeitschrift für Allgemeine Erdkunde, N. F. IX, 194-217, 285-308. Berlin, 1860.

SCHULTZ, WOLDEMAR: Reisen und Arbeiten in Brasilien. Petermann's Mittheilungen, 1860, 159-160 (Notice). Gotha, 1860.

SCHULTZ, WOLDEMAR: Aufnahme und Erforschung des Stromlaufes des Rio São Francisco in Brasilien. Mit einem Nachtrage von $H$. Kiepert. Zeitschrift für Allgemcine Erdlunde, Neue Folge, $\mathbf{X}$, 214-228. Berlin. 1861.

SCHUITZ, WOIDEMAR: Studien über agrarische und physikalische Verbältnisse In Südbrasilien. Mit einem atlas. $8^{\circ}, 224$ pp. Leipzig, 1865. Pages 209-224 contain a Beilage on Mineralogy by Gustav Jenzsch. The atlas has geologic sectlons. 
SCHUMACHER, P. H.: Beschreib. meiner Reise von Hamburg nach Brasilien im Juni, nebst Nachrr. üb. Brasilien bis. z. Sommer 1825 u üb. die Auswanderer dahin. Der Wahrheit gemäfz u. z. Warnung niedergesshrieben. $8^{\circ}$. Braunschweig, 1826.

SCHUPP, P. AMBROSIO: Uma contribuição para a geologia do Rio Grande do Sul. Annuario do Estado do Rio Grande do Sul, Para o anno de 1905. 311-320. Porto Alegre, 1904.

SCHUSTER, K.: Petrographische Ergebnisse der brasilianischen Expedition 1901 der Kais. Akademie der Wissenschaften Sitzungsbericht der Kaiserl. Akademie der Wissenschaften in Wien. Math-naturw. Klasse, CXVI, Abt. I, Juli, 1907, 93 pp.

SCHWARZ, ERNEST, H. I.: The former land connection between Africa and South America. Journal of Geology, XIV, 81-90. Feb.-Mar., 1906.

SCHWERIN, MARTIN: Gold mines of Minas, Brazil. Engineering and Mining Journal, LXXVIII, 547-548. New York, Oct. 6, 1904. Abstract: Mining Magazine, XI, 68-69. New York, Jan., 1905.

SCOTT, D. H.: Studies in fossil botany, XIV +533, $8^{\circ}$, ill. London, 1900. Psaronius brasiliensis, 272-275.

SCOTT, HERBERT KILBURN: The manganese ores of Brazil. Journal of the Iron and Steel Institute, LVII, 179-208, figs., pls., V-XIV. Condon, 1900. Also as separate, $8^{\circ}$, 1-30, maps and ills. London, 1900. Colliery Guardian, IXXIX, 929-931, figs. (1naps), 1900. Abstract: The Afining Journal, May 26, 1900, LXX, 631. I Iondon (1900). Zeitschrift für Pralt. Geol., IX, pp. 263-265. Berlin, 1901.

SCOTT, H. KILBURN: A visit to the gold mining districts of Brazil. Feilden's Magazine, IV, 560-572, $4^{\circ}$, ill. London, May, 1901.

SCOTT, HERBERT KILBURN: The iron ores of Brazil. Journal of the Iron and Steel Institute, London, 1902 . Also separate, 20 pp., illustrated. Iondon, 1902. Abstract: Bfonthly Bul. Inter. Bureau of Amer. Republics, XII, 1434-1436. Washington, 1902. Abstract: The Mining Journal, Railuay and Commercial Gazette, LXXII, 652. London, May 10, 1902.

SCOTT, HERBERT KILBURN: Iron making in Brazil. Engineering and llining Journal, LXXIY, 680. New York, Nov. 22, 1902.

SCOTT, HERBERT KILBURN: Iron ores of Brazil. Engineering and Mining Journal, LXXIV, 750. New York, Dec. 6, 1902.

SCOTT, HERBERT KILBURN: O Manganez no Brazil. Reproduzido do Jorual do Commercio Rio de Janeiro. Cap. I, ***. Cap. II, Historia, Jornal do Commercio, 26 Set. de $1902 ; 8^{\circ}, 58$ pp. Rio de Janeiro, Oct. 2, 1902. Review : Engineering and Mining Journal, LXXV, 601. New York, April 18, 1903.

SCOTT, HERBERT KILBURN: The gold fields of the state of Minas Geraes, Brazil. Trans. Amer. Inst. Min. Engs., XXXIII, 406-444, ill. New York, 1903.

SCOTT, H. KILBURN: Brazilian manganese. Second article. Brazilian Mining Review, I, 85-88. Rio de Janeiro, Jul., 1903. (The article entitled "Manganese ore" under Anon. is the first part of this article.) Also in Monthly Bulletin of the Bureau of Amer. Republics, XVI, 663-665. Washington, 1904.

SCOTT, H. K.: Mica in Brazil. Mines and Minerals, XXIV, 34-37. Scranton, Aug., 1903. Extract: Zeitschrift fïr Prakt. Geologie, XII, 110-111. Berlin, 1904. This paper is the same as the one "On the occurrence of mica."

SCOTT, H. KILBURN: The mineral resontres of the state of Rio Grande do Sul, Brazil. Transactions of the Institute of Mining Engineers, XXV, 510528. London and Newcastle-upon-Tyne (1903). Separate, ill., 20 pp. London and Newcastle-upon-'Tyne, 1903. Part of this article without the author's name appears in Brazilian Mining Rerien, I, 206-207, 215-218. Rio de Juneiro, 1904. 
SCOTT, H. KILBURN: On the occurrence of mica in Brazil and on tts preparation for the market. Transactions of the Institute of Mining and Metallurgy, XII, 351-364. London, 1904 . Also separates of $13 \mathrm{pp} .8^{\circ}$, ill. London, 1903.

SCOTT, H. KIIBURN: (Discussions of the origin of diamonds.) Trans. Inst. of Mining and Metallurgy, XII, 133-134. London, 1904.

scoul.ER: Account of a voyage to Madelra, Brazil, Juan Fernandez, and the Gallapagos Islands, performed in 1824 and 1825, with a view of examining their Natural History, etc. Edinburg Jour. Sci., Oct., 1826, V, 195-201. Edinburgh, 1826. Notes on the geology of Rio de Janeiro. Review : Zeitschrift für Mineralogie, von Leonhard, Jahrgang, 1827, I, 322. Frankfurt a. M., 1827.

SEAMON, W. H.: Analysis of native palladium gold from Taquaril near Sabara, province of Minas Geraes, Brazll. Chemical News, 1884, XLVI, 216

SEGURO, PORTO: $\nabla$. PORTO SEGURO.

SELIGMANN, G.: Brazilian diamonds. Verhandlungen Nat. Ver. Preuss. Rheine, XXXVIII, 182-183, with plate. Bonn, 1881.

BELL.IN, A. W.: Das Kaiserelch Brasilien. I Iefpzig u. Prag, 1885. Der Berg.bau, 219-225.

SELLOW, FREDERICK: $\nabla$. WEISS.

SELWYN, ALFRED R. C.: Origin of lake-basins. Geological Magazine, Feb., 1877. New Ser. Decade II, vol. IV, 94. Iondon, 1877. Note on rock decay In Brazil.

SENA, J. C. DA COSTA: Viagem de estudos metallurgicos no centro da provincia de Minas-Geraes. Annaes da Escola de Minas de Ouro Preto, No. 1, 95-128. Rio de Janelro, 1881.

SENA, COSTA: Analyse do phosphato de cal da Ilha Rata, Fernando de Noronha. Annaes da Escola de Minas de Ouro Preto, 1881, No. II, 142. Ouro Preto, 1883. Auxiliador da Industria Nacional, No. 7, LI. 165 . Rlo de Janeiro, Julho de 1883. Revista de Engenharia, V, 272. Rio de Janeiro. 14 de Out., 1883.

SFNA, JOAQUIM CANDIDO DA COSTA: Noticia sobre a mineralogia e geologia de uma parte do Norte e Nordeste da Provincia de Minas-Geraes. Annaes da Escola de Minas de Ouro Preto, 1883, N. 2, 111-131. Auxiliador da Industria Nacional, N. 10, Outubro de 1883, 225-234. Rio de Janeiro. 1883. Revista de Engenharia, 14 de Janeiro de 1884, VI, 4-6; 28 de Jan. de 1884, VI, 16-18; 14 de Fev. de 1884, VI, 28-30. Rio de Janeiro, 1884.

SENA, J. C. DA COSTA: Noticia sobre a scorodita existente nas visinhanças do arralal de Antonio Pereira e sobre a hydrargillita dos arredores de Ouro Preto. Annaes a Escola de Minas de Ouro Preto, No. 3, 211-215. Rlo de Janeiro, 1884.

SENA, COSTA: Analyses de calcareos feitas no laboratorio de docimasla, etc. Annaes da Escola de Minas de Ouro Preto, No. 3, 233. Rlo de Janelro, 1884.

sENA, J. DA costa: Note sur la scorodite des environs d'Ouro Preto. Bull. Soc. Minéral. de France, VII, 218-220. Paris, 1884. Abstract: Neues Jahrb. f. Mineral., 1886, II, 352 (Referate). Abstract: Zeitschrift für Krystallographie und Mineralogie (Groth), XI, 639-640. Leipzig, 1886.

SENA, COSTA: Note sur l'hydrargillite des environs d'Ouro Preto. Bull. Soc. Minéral. de France, VII, 220-222. Paris, 1884. Abstract: Zeitschrift für Krystallographie und Mineralogie (Groth), XI, 640. Leipzig, 1886.

SENA, COSTA: Sur un gisement de staurotides des environs d'Ouro Preto. Bull. Soc. Francaise de Minéralogie, XIII, 189-192. Paris, 1890. Revista Industrial de Minas-Geraes, Anno 1, 16-17. Ouro Preto, 15 de Outubro, 1893. 
SENA, COSTA: Bioxydo de manganez. Revista Industrial de Minas-Geraes, Anno I, No. 3, 67. Ouro Preto, 15 de Dezembro de 1893. Notice: Zeitschrift für pralctische Geologie, 45-46. Berlin, Jan., 1895.

SENA, J. C. DA COSTA: Note sur un gísement d'actinote aux environs d'Ouro Preto, a Minas-Geraes, Brêsil. Bull. Soc. Frunçaise de Minéral., XVII, 267-269. Paris, 1894. The same article is credited to J. A. da Costa Sena in Bull. Soc. Francaise de Minéral., XVI, 206-208. Paris, 1893. Abstract: Neues Jahrb. f. Min., 1895, I, 20. Abstract: Zeitschrift für Krystallog. und Mineralog., $\mathbf{X X V}, 316$. Leipzig, 1896. In Portuguese-Nota sobre uma jazida de actinote. Annaes da Escola de Minas, No. 5, 11-15. Ouro Preto, 1902.

SENA, JOAQUIM CANDIDO DA COSTA: Exposição Mineralogica e Metallurgica de Santiago do Chile. Annexo No. 7 do Relatorio Apresentado ao Dr. Presidente do Estado de Minas-Geraes pelo Secretario de Estado dos Negocios da Agricultura, Commercio e Obras Publicas, Dr. Francisco Sá em o anno de 1895, Vol. II, Annexos 43 pp., $4^{\circ}$. Ouro Preto, 1895. Contains notes on Brazilian minerals, ores and rocks.

SENA, JOAQUIM CANDIDO DA COSTA: Minas de ouro do Cybrão, Municipio de Marianna. Revista Industrial de Minas-Geraes. Anno IV, No. 22, 276. Ouro Preto, 30 de Março de 1897.

SENA, J. C. DA COSTA: Mineração dos arredores de Ouro Preto. Revista Industrial de Minas Geraes. Anno V, N. 34, 143. Ouro Preto, 10 de Dez. de 1897.

SENA, COSTA: Mineral resources of the State of Minas-Geraes, Brazil. Translated from the Portuguese by Dr. Alcides Medrado. Mining and Metallurgy, XXIV, 703-705, illustrated. New York, Dec. 15, 1901. Also Brazilian Mining Reviev, I, 11-13. Ouro Preto, JuI., 1902.

SENA, J. C. DA COSTA: Nota sobre uma jazida de staurotidas nas visinhameas de Ouro Preto. Annues da Escola da Minas, No. 5, 7-10, 1902. Ouro Preto, 1902.

SENA, COSTA: (Mineml resources of Minas.) Quoted from "Minas Geraes" in Bulletin of the Intcruational Bureau of American Republics, XII, 1169. Washington, 1902.

SENA, J. C. DA COSTA: The occurrence of tin in Minas Geraes. Brazilian Mining Review, I, 92-93. Rio de Janeiro, July, 1903.

SENA, COSTA: Notas sobre a cassiterita no norte do Estado de Minas Geraes e sobre a apatita e o topazio provenientes dos arredores de Fortaleza e cidade de Salinas. Annaes da Escola de Minas, No. 6, 5-11. Ouro Preto, 1903.

SENA, JOAQUIM CANDIDO DA COSTA: Nota sobre uma jazida de blenda, no municipio de Ouro Preto, ete. Annaes da Escola de Minas de Ouro Preto, No. 8, 17-22. Ouro Preto, 1906.

SENA, J. C. DA COSTA, and DOMINGOS ROCHA: The Tapera gold deposits. Brazilian Mining Review, I, 221. Rio de Janeiro, May, 1904.

SENNA, NELSON COELFO DE: O estado de Minas Geraes no exposição universal de S. Luiz. $8^{\circ}$. Bello Horizonte, 1904. Geologica, 20-35.

SERIS, M. H. L.: Le Brêsil pittoresque d'après ses géographes et ses explorateurs. $8^{\circ}$, ill. Limoges, 1881 . Physical features, $18-41$; diamants et pierres précieuses, 91-95; autres métaux, 95-102. This work forms part of the Bibliotheque des voyages.

SERRES, MARCEL DE: Note sur la pétrification des coquilles dans l'océan actuel. Compt. Rend., XXXVI, 14-16. Paris, 1853. The Bahia stone reefs.

SERRES, MARCEL DE: Sur les coquilles pétrifiées des environs de Bahia. Comptes Rendus de l'Acart. Sci., XXXVII, 362-363, Paris, 1854. 
SERRES, MAROEL DE: Sur les dépôts récents des côtes du Brésil. Extrait d'une lettre a clie de Beaumont. Comptes Rendus de l'Acad. Sci., L, 907. Paris, 1860.

SEVERIANO: $\nabla$. FONSECA, J. SEVERIANO.

SEWARD, A. C.: Floras of the past: their composition and distribution. $\mathrm{Na}-$ ture, Oct. 8, 1908, 556-568. London, 1903. Premo-Carbonlferous flora of Southern Brazil.

SEYBERT, HENRY: Analyses of the cymophane from Haddam and from Brazil. Annals of Philosophy, London, June, 1823. Abstract: Bul. des Sci. Nat. et de Géol., Aout, 1824, 335-336. Parls, 1824.

SEYBERT, HENRY: Analyses of the chrysoberyls from Haddam and Brazil. Annals of Philosophy, London, June, 1824, New series, VII, 427-432. Transactions of the Amer. Phil. Soc., New series, II, 116-123. Philadelphla, 1825. Abstract: Bulletin des Sciences Naturelles et de Gélogie, No. 6, Juin, 1825, 211-212. Paris, 1825. Abstract: Annales des Mines, $\mathrm{X}, 289$ 291. Paris, 1825. Mineralogisches Taschenbuch von Leonhard, für des Jahr. 1824, 3d Abth., 831-844. Frankfurt a M., 1824. Amer. Jour. Sci., 1824, VIII, 145-149; Schweigger's Journal für Chemie u. Physik, XLII, 228-236. Nürmberg, 1824.

SIEMIRADZKI, JOSEF V.: Zur Geologie von Nord-Patagonien. Neues Jahrbuch für Mineralogie, I, 22-32. Stuttgart, 1893. Reference to Parank geology, 31.

SIEMIRADZKI, JOS. V.: Geologische Reisebeobachtungen in Sudbrasillen. sitz. Ber. Akad. Wiss. Mat.-nat. Cl. CVII, Abt. 1, 23-39, 1 Taf., 1 fig. Wien, 1898.

SIEMIRADZKI, JOSEF: Bogactwo kopalniane brazylijskiego stanu Paraná. Przegl. emigracyjay, Lemberg. 2, 153-154. Mining properties of the state of Paraná, Brazil.

SIEVERS, WII.H.: Das Hochland von Brasilien. Aus Siever's "Amerika," Zeitschrift fïr Schul-Geographie, XIV, Jahrgang, 362-373. Wien, 1893.

SIEVERS, WILHEIM: Süd- und Mittelamerika. Roy. $8^{\circ}$, XII +665 pp., ill. Leipzig und Wien, 1903. Geological map of South America on 57; bibliography, 616-630.

SIEVERS, W.: Die Geologie des unteren Amazonasgebiets. Review of Katzer's work of this name. Globus, LXXXV, 306. Braunschweig, 19 Mai, 1904.

SILVA, ANTONIo DA COSTA PINTO: S. João de Ypanema. Descripção do morro do mineral de ferro, sua riqueza, methodo usado na antiga fabrica, seus defeitos. Revista do Inst. Hist., XVIII, 235-243. Rio de Janeiro, 1855.

SILVA, AUGUSTO BARBOSA DA: See Gomes, Carlos Thomaz.

SILVA, IGNACIO ACCIOII DE CERQUEIRA E: See Accioli.

SILVA, JOSE FRANKIIN DA: Descripgño do Itatiala ou Itltlalo. With fig. (Dated Dec. 3, 1856.) Revista do Inst. Hist., XXXIX, parte I, 413-418. Rio de Janeiro, 1876.

SITVA, JOSE FRANKIIN DA: Panorama do Sul de Minas. Revista Inst. Hist., XLV, parte II, 405-435. Rio de Janeiro, 1882. On physical features, geology and natural history. Quoted in Diccionario Geographico das Minas do Brazil por F. I. Ferreira, 662-668. Rio de Janeiro, 1885.

SILVA, J. M. PEREIRA DA: Historia da fundação do Imperio Brazileiro. Rio de Janeiro, 1864. Productos do Brazil ; ouro, diamantes, I, 244-253.

SILVA, MIGUEL A. DA: Do solo agricola. Revista Agricola do Imperial In . stituto Fluminense de Agricultura, No. 1, 25-36. Rio de Janeiro, de Setembro de 1869. 28-29, 35,36 on Brazilian soils. 
SILVA PONTES: $\nabla$. PONTES, M. J. P. DA SILVA.

SILVA, THEODORO MACHADO FREIRE PEREIRA DA: Relatorio apresentado a assembléa geral legislativa na terceira sessão da 14a legislatura pelo Ministro e Secretario de Estado dos Negocios da Agricultura, Commercio e Obras Publicas. $4^{\circ}$. Rio de Janeiro, 1871. Mineração, 59-63.

SILVEIRA, ALVARO ASTOLPHO DA: Relatorio do Geologo da Commissão Geographica e Geologica de Minas durante o anno de 1894, 23-34 do Annexo No. 3, sub-annexo F. do Relatorio apresentado ao Dr. Presidente do Lstado de Minas Geraes pelo Secretario de Estado dos Negocios da Agricultura, Conımercio e Obras Publicas Dr. Francisco Sá em o anno de 1895, II. Ouro Preto, 1895. Apparently the same article is Annexo F. of "Relatorio apresentado ao Secretario d' Agricultura, Commercio e obras Publicas do Estado de Minas Geraes pelo Engenheiro Chefe da Commissão Geographica e Geologica do mesmo Estado, Augusto Abreu Lacerda." S. João d'El Rei, 1895.

SIIVEIRA, ALVARO: Analyse No. 3. Calcareo da pedreira da Capoeira Grande a um kilometro de Barroso. Revista Industrial de Minas Geraes. Anno I, No. 9, 232. Ouro Preto, 15 de Junho, 1894.

SIIVEIRA, ALVARO ASTOLPHO DA, ENGENHEIRO CHEF: Relatorio da Commissũo Geographica e Geologica. Annexo A do Relatorio apresentado ao Dr. Secretario de Estado da Agricultura do Estado de Minas Geraes pelo Inspector de 'lerras e Colonização em 1897. Ouro Preto, 1897. Anlnexo $A$, 1-9.

SILVEIRA, ALVARO ASTOLPHO DA: As folhas da Carta de 1 a 100,000 do Estado de Minas. Revista Industrial de Minas Geraes, Anno V, No. 27, 4042. Ouro Preto, 20 de Agosto, 1897.

SILVEIRA, ALVARO ASTOLPHO DA: (Trabalhos da Commissão Geographica e Geologica durante o anno de 1897.) Annexo A do Relatorio apresentado ao Dr. Secretario de Estado da Agricultura do Estado de Minas Geraes pelo Inspector de Terras e Colonização, Dr. Carlos Prates em 1898, 109-117. Bello Horizonte, 1898.

SILVEIRA, ALVARO ASTOLPHO DA: Contribuição para o estudo do clima das montanhas elevadas de Minas Geraes, etc. Boletim No. 5 da Comnissão Geographica e Geologica do Estado de Minas Geraes, II, 146-167. Rio de Janeiro, 1898. Mountain elevations in Minas.

SILVEIRA, ALVARO ASTOLPHO DA: Relatorio da Commissão Geographica e Geologica. Annexo D do relatorio apresentado ao Dr. Presidente do Estado de Minas pelo Secretario de Estado dos Negocios da Agricultura, Commercio e Obras Publicas, Dr. Americo Werneck, em o anno de 1899, 301-304. Cidade de Minas, 1899.

SILVEIRA, AIVARO A. DA: Relatorio sobre os tremores de terra em Bom Successo, Estado de Minas Geraes. Minas Geraes, orgão official dos poderes do Estado. Bello Horizonte, 1 de Novembro de 1901. Anno X, No. 286, 1-2.

SILVFIRA, ALVARo DA: Os tremores de terra em Bom Successo, Minas Geraes, Bello Horizonte, $1906 . \quad\left(12^{\circ}, 137\right.$ pp. $)$

SILVEIRA, MONSENHOR ANTONIO FERNANDES DA: Officio sobre a existencia de preciosas minas de ferro e d'um rio subterraneo na provincia de Sergipe. Revista do Inst. Historico, XXIII, 129-130. Rio de Janeiro, 1860.

SILVEIRA, COSTA: Ensayo d'um quadro estatistico da provincia de São Paulo. $8^{\circ}$. S. Paulo, 1839. Abstract: Nouvelles Annales des Voyages, XCVII, 115-122. Paris, 1843.

SIIVEIRA, FRANCISCo JOSA DA: Sobre nitreiras de Minas Geraes (circa 1800). Revista do Archivo Publico Mineiro. Anno III, fasc. II, 270. Bello Horizonte, Abril a Junho, 1898. 
SIMCH, FRANCIsco R.: A formação geologica de Porto Alegre (Rio Grande do Sul). Publicada no jornal $A$ Federacão, Porto Alegre, Brazil, 12 de Abril (no. 86) ; 14 de Abril (no. 87) ; 16 de Abril (no. 89) ; 18 de Abril (no. 91) ; 26 de Abril (no. 97) ; 29 de Abril (No. 99) de 1902.

sIMONDS, F. W.: Professor Ch. Fred. Hartt, M. A.-A tribute. American Geologist, XIX, 69-90. Minneapolis, 1897.

SMITH, ERWIN F.: Lagôa Santa. Resumé of "Et Bidrag til den biologiske Plantegeografi" of E. Warming, q. v. Science, May 10, 1895, New Ser., I, 510-515. New York, 1895.

SMITH, HERBERT H.: Geology and physical geography of the Amazons valley. Appendix to "Brazil, the Amazons and the coast," 619-635. New York, 1879.

SMITH, H. H.: Discovery of paleozoic rocks in Western Brazil. The American Naturalist, XVII, 1156-1157. Philadelphia, 1883. Chapadão near Cuyaba, Matto Grosso.

SMITH, H. H.: The naturalist's Brazilian expedition. American Naturalist, XVII, 351-358, 707-716, 1007-1014. Philadelphia, 1883. American Naturalist, XVIII, 464-470, 578-586. Philadelphia, 1884.

SMITH, H. H.: O planalto de Matto Grosso. Revista de Engenharia, 28 de Janeiro de 1885, VII, 17-18. Rio de Janeiro, 1885, from the Jornal du Commercio, Rio de Janeiro.

SMITH, H. H.: Notes on the physical geography of the Amazons Valley Amer: Naturalist, XIX, 27-37. Philadelphia, Jan., 1885.

SMITH, H. H.: Is Brazil a fertile country? The Rio News, XII, 3-4. , Rio de Janeiro, Feb. 24, 1885.

SMITH, H. H.: (Physical features of the upper Paraguay.) Revista de Engenharia, 14 de Jan. de 1885, VII, 9-10. From the Jornal do Commercio, Rio de Janeiro, 1885.

SMITH, HERBERT H.: Do Rio de Janeiro a Cuyaba. Notas de um Naturalista. $16^{\circ}, 416$ pp. Rio de Janeiro, 1886. Notes on geology, 187, 216, 262, 314 et seq., 378, 400-403.

SMrTH, H. H.: Brazil. Johnson's Universal cyclopoedia. A new edition. I, 745-747. New York, 1893.

SMITH, H. H.: Trabalhos restantes ineditos da Commissão Geologica do Brazil (1875-1878), IX, Paracary. Boletim do Museo Paraense, II, No. 3, 359366. Para, 1898. Referate: Peternann's geographische Mitteilungen, 1898, XLIV, Literaturbericht, 208.

SMITH, HERBERT H.: Geologia do Rio Grande do Sul. Annuario do Estado do Rio Grande do Sul para o anno de 1901. Publicado sobre a direcção de Graciano A. de Azambuja. 12 ${ }^{\circ}$, 113-122. Porto Alegre, 1900. Compilation from Smith's paper on "The Nat. Brazilian Expedition" in the American Naturalist, 1883, 1884, q. v.

SMITH, J. LAWRENCE: Anomalie magnétique du fer météorique de SainteCatherine. Comptes Rendus de l'Acad. Sci., XCII, 843-844. Paris, 1881.

SMITH, J. LAWRENCE: V. BECQUEREL, $H$.

SMYTH, LIEUT.: Account of the Rivers Amazon and Negro, from recent observations (map). Journal of the Royal Geographical Society, VI, 1123. London, 1836.

SMYTH, WIILIAM, and LOWE, FREDERICK: Narrative of a journey from Iima to Pará across the Andes and down the Amazon; undertaken with a view of ascertaining the practicability of a navigable communication with the Atlantic by the rivers Pachica, Ucayall, and Amazon. VII +305 pp., $8^{\circ}$, maps and plates. London, 1836 . Notes on physical features. Abstract: Nouelles Annales des Voyages, IXXIII, 76-86. Paris, 1837.

SOARES DE SOUZA: v. SOUZA, G. SOARES DE. 
SOBRAGY, BENTO JOSE RIBEIRO: (Analyse do) Phosphato da Ilha Rata. Revista Agricola do Imperial Instituto Fluminense de Agricultura, XII, No. 2, 54. Rio de Janeiro, Junho, 1881.

SODRE, PEDRO DE CASTRo PEREIRA: Aperçu général sur la république des tetats-Unis du Brésil. $8^{\circ}$. Genève, 1893. Minéraux, 19-20.

SOLMS-LAUBACH, H. GRAFEN ZU: Fossil Botany, being an introduction to palaeophytology. Translation by Henry E. F. Garnsey. Revised by I. B. Balfour. Oxford, 1891. Psaronius from Brazil, 170-171.

SOLMS-LAUBACH, H. GRAFEN ZU: Ueber die Schicksale der als Psaronius brasiliensis beschriebenen Fossilreste unserer Museen. [Festschrift zur Feier des siebzigsten Geburtstages des Herrn Professor Dr. Paul Ascherson.] 18-26, $8^{\circ}$. Leipzig, 1904.

SOUZA, ANTONIO ENNES DE: Sulphureto de chumbo (na provincia do Maranhão). Diccionario historico-geographico da provincia do Maranhão. Por Cezar Augusto Marques. 518-520. Maranhão, 1870.

SOUZA, AUGUSTo FAUSTo DE: A Bahia do Rio de Janeiro, sua historia e descripção de suas riquezas. Revista do Instituto Historico, XLIV, parte II, 5 et seq. Rio de Janeiro, 1881. Descripção geral e geologia, 71-73.

SOUZA BRAZIL: v. POMPEO DE SOUZA.

SOUZA, COLATINO MARQUES DE: As riquezas naturaes do Estado du Bahia. Revista Trimensal do Instituto Geographico e Hist. da Baltia, V, 437-450. Bahia, Setembro de 1898.

sOUZA, D. DIOGo DE: (Carvão de pedra na Capitania de S. Pedro.) Officio dirigido ao Conde das Galvêas, 29 de Março de 1812. Revista Inst. Hist., XLI, parte I, 365-366. Rio de Janeiro, 1878.

SOUZA, GABRIEL SOARES DE: Tratado descriptivo do Brazil em 1587. Obra de Gabriel Soares de Souza. Revista do Instituto Historico, XIV. Rio de Janeiro, 1851. Cap. 187, p. 354-5. Esse que se declara a pedra que tem a Bahia. Cap. 188, p. 355-356 . . . o commodo que tem a Bahia, para se poder fazer muita cal. . . . Cap. 193, p. 361 . . . o ferro, aço e cobre que tem a Bahia. Cap. 194, p. 362 ... pedras verdes e azues que se acham no sertão da Bahia. Cap. 195, p. 363 . . . o nascimento das esmeraldas e safiras. Cap. 196, p. 364-5 ... ouro e prata que ha na comarca da Bahia. A mesma obra foi publicada sem nome do author na Colleccão de Noticias para a historia e geographica des Nacões Ultramarinas (etc.) publicada pela Academia Real das Sciencias, tomo III, parte I, pp. 1-432, $8^{\circ}$. Lisbôa, 1825.

SOUZA, MANOEL DE: Descripção geologica do Tocantins, aspecto e disposição pedregosa e fluvial de suas cachoeiras. Bibliotheca Guanabarense. Trabalhos da Soc. Vellosiana, 132-148. This is the end of the Diario da Expedição Colonisadora do Alto Tocantins (Junho, 1849 a Jan. de 1850) Rio de Janeiro.

SPEZIA, GIORGIO: Sulla flessibilita dell'Ltacolumite. Atti della $R$. Accademia delle Scienze di Torino, XXI, 1885-1886, 51-54. Torino, 1885 . Abstract: Bull. Soc. Francaise de Mineral., 1886, IX, 308. Abstract: Neues Jahrb. f. Mineral., 1887, I, 427 Referate.

SPIX und MARTIUS: Reise in Bresilien auf Befehl Sr. Majestät Maximilian Joseph I, Königs von Baiern in den Jahren 1817 bis 1820 gemacht und beschrieben von Dr. John. Bapt. von Spix. . . und Dr. Carl Friedr. Phil von Martius. München. $4^{\circ}, \mathrm{I}, 1823,1-412$. II, 1828, 415-884. III, 1831, 887-1388, and Geographischer Anhang. Ueber die General Karte von Südamerica von Professor Fr. Ed. Desberger, 1-39. Höhenpuncte in par. Fuss nach den barometrisshen Beobachtungen von W. v. Eschwege, v. Spix und v. Martius, 39-40. Atlas, plates XXII, fig. 5, fossil fish. These vols. contain many notes upon the geology and physical geography. The first vol. was translated into English. See below. Abstract of vol. I : Bul. des 
Sci. Nat. et de géologie, No. 5, Mai, 1825, 42-45, Paris, 1825; No. 5, Mai, 1827, 23-25, Paris, 1827. Abstract of vol. II : Bull. des. Sci. Naturelles et de Géologie, XXII, 214-231, 252. Paris, 1830.

SPIX und MARTIUS: Travels in Brazil in the years 1817-1820 undertaken by command of His Majesty the King of Bavaria. By Dr. Joh. Bapt. von Spix and Dr. C. F. Phil. von Martius. (Translated by H. E. Lloyd.) 2 vols., $8^{\circ}$, ill. Vol. I, xiv +327 ; vol. II, xif $\times 298$. London, 1824 . Contains notes on the geology and physical geography.

SPIX und MARTIUS: Mineralogische Bemerkungen der Herrn von Spix und von Martius auf ihrer brasilianischen Reise. Neues Jahrbücher der Bergunl Hïttenlcunde von C. E. F. von Moll. 6ten. Bandes 1te Lieferung, 1-128, $8^{\circ}$. Nürnberg, 1825. Abstract under title: "Extrait géologique de differens ouvrages sur Brésil," Bulletin des Sci. Nat. et de Géologie, No. 5, Mai, 1827, 25-27. Paris, 1827.

SPRUCE, RICHAED: On the river Purás. Report British Assoc. Adv. Sci., 1864 ; 'Transactions, 148. London, 1865.

SPURR, J. E.: Ore deposits of the Silver Peak Quadrangle, Nevada. Professional Papel: no. 55, U. S. Geol. Survey. $4^{\circ}$. (Quotations regarding the occurrence of gold in Brazil. pp. 145-149.) Washington, 1906.

STEAINS, WM. JOHN: An exploration of the Rio Dôce and its northern tributaries (Brazil). Proceedings Royal Geographical Society, $\mathrm{x}, 61-84$. London, 1888.

STEHR, JOHANN: Die Diamanten und Carbonate von Bahia (Brasilien). Bergbau, Gelsenkirchen XVI, No. 9, 3-5, 1902.

STEIN, SIEGFRIFD: Eine Fahrt nach Brasilien. Stahl und Eisen, Düsseldorf, 1887 , No. 4,7 pages.

STEINEN, KARI VON DEN: Erforschung des Xing siliell. $8^{\circ}, 372$ SS., mit Karten. Leipzig, 1886. Abstract: Petermann's Mittheilungen, XXXII, 219-220. Gotha, 1886. Review: Proceedings Royal Geograplical Society, n. s., VIII, 517-522. Iondon, 1886.

STEINMAN, GUSTAV: A sketch of the geology of South America. American Naturalist, XXV, 855-860. Philadelphia, 1891. Abstract: Neues Jahrb. f. Mineral., 1893, I, 48-49, Referate.

STEINMANN, G.: Atlas der Geologie, Südamerika. Berghaus' Physikalischer Atlas, 6-7, Kart No. 14, folio. Gotha, 1892.

STEINMANN, G.: Beiträge zur Geologie und Paleontologie von Südamerika. Vorwort von der Pal. Versteinerungeu aus Bolivien, q. v. Neues Jahrb. $t$. Mineral., Beilage Band, VIII, 1-4. Stuttgart, 1893.

STILLMAN, J. M.: (On borra, an organic substance found near Buique, Pernambuco.) Bul. Geol. Soc. Amer., XIII, 74. Rochester, 1902.

STRAIN, ISAAC G.: (Synopsis of a letter from Lund to the Instituto Historico, q. v.) Proceedings of the Acad. of Natural Sciences of Philadelphia, II, 11-14, $8^{\circ}$. Philadelphia, 1844.

STREFTER, EDWIN W.: Precious stones and gems-their history, sources, and characteristies. 6th ed., $8^{\circ}, 339$ pp. London, 1898. Brazilian diamonds, 106-116; carbonados, 143-144.

STURz, J. J.: Neue Beiträge jiber Brasilien und die La Plata-Länder. $\mathbf{8}^{\circ}$, $84 \mathrm{pp}$. Berlin, 1865. The introduction is signed by J. D. Sturz.

STZ., J. D.: Golpe de vista da America do Sul. Dresde em Marco de 1855. A physical, soil, and forest wall-map of South America. Scale, $1: 8,000,000$. The author is probably Sturz, though the full name is not given.

SUESS, ED.: La face de la terre. (Das Antlitz der Erde.) Traduit de l'Allemand (etc.), I. Paris, 1897. Chap. IX, L'Amerique du Sud. Le massif du Brésil, 675-682, II. Paris, 1900. L'est de l'Amérique Centrale et de l'Amérique du Sud, 219-227. 
SUZANNET, IE COMTE DE: Souvenirs de voyages. Les Provinces du Caucase, l'Empire du Brésil. Paris, Dentu, 1846. Brésil, 193 et seq. Chap. V, 295-327. Les mines d'or, etc. Chap. VI, 328-337. La province de Diamantina. Chap. VII, 338-364. Exploitation des diamants dans la Serra del Gram Mogol. Review: Nouvelles Annales des Voyages, CXVI, 341354. Paris, 1847.

SVANBERG: Analyse de trois menerais de platine du Brésil. Annales des Mines, 3me série, VIĪ, 557-558. Paris, 1835.

TASSART, L. C.: Exploitation du petrole. Imp. $8^{\circ}$, ill. Paris, 1908 . (Brếsil, p. 317.)

TAUNAY, AIFREDO D'ESCRAGNOLLE: As Caldas da Imperatriz, aguas thermaes da Provincia de Santa Catharina. Revista Inst. Hist., XLII, Parte II, 39-53. Rio de Janeiro, 1879.

TAUNAY, VISCONDE DE: Curiosidades naturaes da Provincia do Parana. Revista do Instituto Historico, LIII, pt. I, 193-241. Rio de Janeiro, 1890. Contains notes on the geology.

TAVARES, CHRISPINIANO: Mineração de ouro. Revista de Engenharia, V, 15-18. Rio de Janeiro, 28 de Janeiro, 1883.

TAVARES, CHRISPINIANO: Jazidas auriferas da Provincia de Minas Geraes. Cruzeiro, Rio de Janeiro, 11 de Marco de 1883. Diario Official, Rio de Janeiro, 9 de Março de 1883. Quoted in Journal Official de l'Empire du Brésil, Rio de Janeiro, 1er Mars, 1883.

TAVARES, CHRISPINIANO: Lavras auriferas de Minas Geraes. Revista de Engenharia, V, 43-45. Rio de Janeiro, 28 de Fev. de 1883.

TAVARES, CHRISPINIANO: Companhia de Mineração Goyana. Relatorio apresentado pelo engenheiro de Minas, Chrispiniano Tavares, 7 de Setembro de 1883. Revista de Engenharia, 14 de Outubro de 1883, V, 265-267; 28 de Outubro de 1883, 280-281. Rio de Janeiro, 1883.

TAYLOR, JOHN \& SONS: Relatorio sobre a lavra de São Luiz, no Caethé, Est. Minas Geraes, Brazil. Paris, 1894.

TEILES, A.: v. GUIGNET, E., and TELIES, A.

TEMPLE: Report on the State of Maranhão, No. 547. Miscellaneous Series. Diplomatic and Consular Reports (British) Foreign Office. February, 1901. London, Printed for His Majesty's Stationery office-1901. Note on geology of Mahanhão, 3 ; minerals, 8.

TERREIL, A.: Analyse d'une argile chromifère du Brésil. Comptes Rendus de l'Acad. Sci, CIV, 983-984. Paris, 1892. Abstract: Zeitschrift für Krystallographie und Mineralogie, XXIV, 517. Leipzig, 1895.

THIBAIRENG, L.: Rapport sur la reconuoissance des gisements aurifêres de la PaImella (province of Minas Geraes), Bresil. $8^{\circ}, 20$ pp. Bruxelles, 1891.

THIRt, A.: Des moyens de développer l'industrie du fer dans la province de Minas Geraes. $8^{\circ}, 50 \mathrm{pp}$. Rio de Janeiro, 1883 .

THIRE, ARTHUR: L'tat de Minas Geraes et sa situation économique actuelle. Revista Industrial de Minas Geraes. Anno I, No. 10, 15 de Julho de 1894, 241-243; No. 11, 269-271; No. 12, 15 de Setembro de 1894, 299-300. Ouro Preto, 1894.

THISELTON-DYER, W. T.: The supposed glaciation of Brazil. Nature, Nov. 2,1893, XLIX, 4 . London, 1893.

THOMAS, IVOR: Neue Beitrage zur Kentniss d. devonisch. Fauna Argentina. Zeit. d. deutsch. Geol. Gesell., LVII, 233-291, 1905.

THOMAS, OWEN R.: Minas Geraes, Brazil. Eng. and Mining Journal, LXXX, 453-455. New York, Sept. 9, 1905. 
THOMSON, THOMAS: Description and analysis of some minerals. Trans. Roy. Soc., Edinburgh, XI, Sideroschisolite from Brazil, 444. Edinburgh, 1831.

THOMSON, SIR WYVILIF: The Voyage of the "Challenger." The Atlantic; a preliminary account of the general results of the exploring voyage of H. M. S. "Challenger" during the year 1873 and the early part of the year 1876. New York, 1878. Fernando de Noronha and Bahia, II, 100-129.

THORNTON, EDWARD: Report on the existence of a large coal-field in the province of St. Catherine, Brazil. Quart. Jour. Geol. Soc., June, 1867, 386387. London, 1867. Abstract: Geological Magazine, IV, 420. London, 1867.

THORNTON, EDWARD: . . . Coal fields in the province of St. Catherine. Reports received from Her Majesty's Secretaries of Embassy and Legation respecting coal. In continuation of papers presented in 1867. Parliamentary Papers, pp. 7-8, $4^{\circ}$. London, 1868.

THORPE, T. E.: On the amount of carbonic acid contained in the atmosphere of tropical Brazil during the rainy season. Jour. Chem. Soc., London (N. S.) , V, 199-201. London, 1867. Abstract: Jahiesbericht der Chemie, 1867, $183-184$.

TIZARD, T, H.: จ. CHALLENGER.

TOLIENARE, I. F. DE: Notas dominicaes, tomadas durante unia residencia em Portugal e no Brasil nos annos de 1816, 1817, e 1818. Parte relativa a Pernambuco traduzida do manuscripto francez inedito por Alfredo de Calvalho, com um prefacio de M. de Oliveira Lima. Recife, 1906. Published by the Instituto Archeologico e Geographico Pernambucano, No. 61 of its Revista. Page 102 refers to fossils found at Cachoeira, an engenho on Rio Pirapama, between Escada and Victoria, State of Pernambuco. At page 172 mention is made of fossils found in a limestone quarry a quarter of a league from Olinda. At 41 the author speaks of the sandstones forming the reefs and of the shells imbedded in them; 102 on granite, schist, etc. This note was written Mar. 2, 1817, and is the earliest mention of fossils in Pernambuco, Brazil. On this point see note under Cazal.

TOLSTOPIATOW, M.: Sur les inclusions dans les topazes de l'Oural et de la Saxe. Verhandlungen der Russisch-Kaiserlichen Mineralogischen Gesellschaft zu St. Petersburg. Ser. II, XXXIII, 290-306. St. Petersburg, 1895. Topazes du Brésil, 303-306. Abstract: Zeitschrift für Krystallograp7ice und Mineralogie, XXVIII, 517-518. Leipzig, 1897.

TOPLEY, WM.: $\mathbf{v}$. REDWOOD, $\mathbf{B}$.

TOUZEAU, E. M.: Gold mining in Brazil. Trans. of North of England Insti. tute of Mining and Mechanical Engineers, XLII, 73-83, Ill. Newcastleupon-Tyne, 1893.

TRELOAR, CAPT.: V. ST. JOHN D'EL REY.

TRELOAR, THOMAS: Notice of a vein containing diamonds near Tijuco, in Brazil. Trans. Roy. Geol. Soc. of Cornwall, VII, 298-299. Penzance, 1865.

TRELOAR, THOMAS: Notice of an issue of inflammable gas in the Morro Velho gold mine, Brazil. Trans. Roy. Geol. Soc. of Cornwall, VII, 345-346. Penzance, 1865.

TSCHERMAK, G.: V. IUDWIG, E.

TSCHERMAK, G.: tber die chemische Konstitution der Feldspate. SitzBerichte de K. Alkad. de Wissen. in Wien. Math.-Naturw. Klasse, CXII, Abt. I, Mai, 1903. Abstract: Neues Jahrbuch für Min., 1905.

TSCHERNYSCHEW, TH.: Die obercarbonischen Brachiopoden des Ural und des Timan. Mémoires au Comite Géologique (Russie), XVI, No. 2, I-VIII and 1-749, plates I-LXIII. St. Petersbourg, Leipzig et Paris, 1902. On 705-708 discussion of the Carboniferous of South America, especlally of Brazill. 
TSCHUDI, J. J. VON: Die Brasilianische Provinz Minas Geraes. Beschrelbender Text von J. J. von Tschudi, 1862. Petermann's Mittheilungen, No. 9, maps, $42 \mathrm{pp}, 4^{\circ}$. Gotha, 1862.

TSCHUDI, J. J. VON: Reisen durch Südamerika, 5 vols, $8^{\circ}$. Leipzig, 18661869. Vols. I, II, III, and IV, up to p. 168, contain notes on the geology of Brazil. Review of I, Das Ausland, XXXIX, 708-713. Augsburg, 17 Juli, 1866. Review of II, XXXIX, 1181-1187. Review of III, XLI, 241246. Review of IV, XLI, 769-774. Augsburg, 1868.

TURNER, H. W.: (Description of quartz-monzonite from Minas Geraes. Results of the Branner-Agassiz Expedition to Brazil, IV.) T'wo characteristic geologic sections on the northeast coast of Brazil, by J. C. Branner. Proc. Washington Acad. Sci., II, 191, footnote. Washington, 1900.

TURNER, H. W.: (Descriptions of eruptives from Pernambuco.) Bul. Geol. Soc. Amer., XIII, 59, 61, 62, 63, 64. Rochester, 1902.

ULRICH, ARNOLD: L'alaeozoische Versteinerungen aus Bolivien. Taf. I-V, u. 2 Holzsch. Neues Jahrb, für Mineralogie, 1893. Beilage Band VIII, 5-116. Stuttgart, 1893.

UNGER, FRANCISCUS: Historia naturalis palmarum, Auctor, C. F. Ph. de Martius. Lipsix [1850?]. I, Caput secuudum. De palmis fossĩlibus. p. LXX, tab. geol. I, fig. 4, a fossil palm-Psaronius brasiliensis Brongu. from the province Piauhy.

VALENTINE, GEORGE: On a carbonaceous mineral or oil shale from Brazil : its formation and composition: as a key to the origin of petroleum. Proc. of the South Wales Inst. of Engineers, XV1I, No. 1, 20-28, 2 ills. London, 1890. Abstract: Jour. Iron and Steel Institute, 1891, I, 310-311. London, 1891.

VAILEE, E. J. C.: Exploração do Rio de Araguaya. Annexo (letra $\mathbf{P}$ ) ao Relatorio do Ministro de Agricultura, etc., 15-33. Rio de Janeiro, 1886.

VAN BENEDEN: $\checkmark$. BENEDEN.

VANDELII, DOMINGOS: Memoria (III) sobre as minas de ouro do Brazil. Annaes da Bibliotheca Nacional do Rio de Janeiro, 1898, XX, 266-278, $4^{\circ}$. Rio de Janeiro, 1899. Publicada de um manuscripto antigo na Bibliotheca Nacional.

VANDELII, DOMINGOS: Varias observações de chimica e historia natural. Cobre nativo do Brazil. Memorias da Acad. Real das Sci. de Lisbóa, I, 259. Lisbôa, 1780 .

VANDELLI, DOMINGOS: Memoria (IV) sobre os diamantes do Brazil. Annaes da Bibliotheca Nacional do Rio de Janeiro, 1898, XX, 279-282, $4^{\circ}$. Rio de Janeiro, 1899.

VAN DEVENTER, M. $\mathbf{L}_{s}$ : Brazilie. Land em Volk geschetst. Door M. L. Van Deventer, oud Consul-General in Brazilie. Amsterdam, 1888. De goudmijnen ven Morro Velho, 98-106.

VAN ERVEN, JACOB: Duarte da Ponte Ribeiro; J. F. Sigaud; Theodoro Villardebo; Commissão. Parecer da Commissão especial (sobre os ossos remettidos ao Instituto pelo Sr. Van Erven). Revista do Instituto Historico, VII, 517-523. Rio de Janeiro, 1845, 2a edição, 1866.

VAN ILEDE, CHARLES: De la colonisation au Brésil. Mémoire historique, descriptif, statistique et commercial sur la Province de Sainte-Catherine. pp. $427+$ viii, $8^{\circ}$. Bruxelles, 1843 . On geology, Chap. IV, 94-125; also Diario do Rio de Janeiro, No. 6525; 15 de Janeiro do 1844. Given in lortuguese in the appendix to Boụbée's "Geologia Elementar," 43-50. Jazigo do carvão de pedra de Santa Catharina: Extracto Cap. X, op. cit. additamento, 51-53. Rio de Janeiro, 1846.

VAN IEDE, CARLOS: Geologia da Provincia de Santa Catharina. Artigo extrahido da memoria historica, estatistica e commercial ... sobre a 
Provincia de Santa Catharina, e vertido em vulgar pelo Dr. A. M. de Miranda Castro. Revista do Instituto Historico, VII, 87-93, 178-195. 2a ed. Rio de Janeiro (2a edição, 1866), 1845.

"VARUNA:" Os trabalhos da Commissão Geologica Brazileira dirigidos pelo Sr. Professor Carlos Hartt. Gazeta de Noticias. Rio de Janeiro, 22 de Junho de 1877.

VASCONCELLOS: $\nabla$. CABRAL.

VASCONCELILS, JOÃO FLORENTINO MEIRA DE: Trechos do relatorio do Presidente da Provincia de Minas Geraes. Auxiliador da Industria $\mathrm{Na}$ cional, No. 10, Outubro de 1881, XLIX. Mineração, 228-230.

VARNHAGEN, FRANCISCO ADOLPHO DE: v. PORTO SEGURO, VISCONDE DE.

VAUQUELIN, LOUIS NICOLAS: Analyse des topazes de Saxe, de Siberie et du Biésil. Ann. Mus. Hist. Nat., VI, 21-25. Paris, 1804.

VAUQUELIN: Analyse d'une espéce de minêral de fer du Brésil. Annales de Chimie et de Physique, XX, 85-88. Paris, 1822. Annales des Mines, VIII, 333. Paris, 1823.

VEIGA, B. S. DA: Gruta notavel. Caverna de Rifana (na Serra da Canastra, Minas). O Novo Mundo, Dezernbro de 1879, IX, 290. New York, 1879. Copied from the Monitor Sul Mineiro.

VEIGA, JOSE PEDRO XAVIER DA, DIRECTOR: (Documentos) Descoberta de diamantes em Minas (1723). Petição de Bernardo da Fonseca Lobo; Recompensa a Bernardo da Fonseca Lobo ; Petição de Silvestre Garcia do Amaral; Nova petição de Silvestre Garcia do Amaral; Ordem regia em favor de Silvestre Garcio do Amaral; Documentos das petições de Silvestre Garcia do Amaral. Revista do Aichivo Publico Mineiro. Direcção e Redacção de José Pedro da Veiga, director do mesmo Archivo. Anno II, Fascic. 2, 271-282. Ouro Preto, Abril a Junho de 1897.

VEIGA, JOSE PEDRO XAVIER DA, DIRECTOR: (Documentos) Grande diamante roubado (1736). Revista do Archivo Publico Mineiro. Anno II, Fasciculo 2, 282-285. Ouro Preto, Abril a Junho, 1897.

VEIGA, JOSE PEDRO XAVIER DA, DIRECTOR: (Documentos) Embusca das esmeraldas (1660). Revista do Archivo Publico Mineiro. Anno II, Fasc., $3^{\circ}$, 519-536. Ouro Preto, Junho a Setembro, 1897.

VEIGA, JOSE PEDRO XAVIFR DA, DIRECTOR: A prata e o chumbo da galena do Abaeté. (Cartas de Antonio Gonçalves Gomide, F. de Monlevade e Barão d'Eschwege, 1813, 1823, 1825.) Revista do Archivo Publico Mineiro. Anno II, fasc., $4^{\circ}, 757-765$. Ouro Preto, 1897.

VEIGA, JOSE PEDRO XAVIER DA, DIRECTOR: (Documentos sobre as) Vicissitudes da industria mineira (1810). Revista do Archivo Publico Mineiro. Anno III, fasc. I, 77-84. Ouro Preto, Janeiro a Março, 1898.

VEIGA, JOSE PEDRO XAVIER DA, DIRECTOR: Revista do Archivo Publico Mineiro. Anno III, fasc. III e IV, Julho a Dezembro de 1898. (Documentos) Chumbo e prata do Abaeté, 748-751 (1826). Galena do Abaeté, 751-754 (1813). Sobre nitreiras, 754-758 (1826) (1845) e Platina de Camargos, 758-760 (1845). Ouro Preto, 1898.

VEIGA, JOSE PEDRO XAVIER DA, DIRECTOR: Documentos diversos. Revista do Archivo Publico Mineiro. Anno IV, fasc. I e II, Janeiro a Junho de 1899. Diamartes na Bagagem (1859), 287-292. Ouro extrahido do Gongo Soco (1834), 293. Diamantes nos rios Indaýa e Abaeté (1800), 296-297. Prata descoberta no Abaeté (1812), 298. Salitreiras de Minas Geraes (1813-37), 299-316. Estabelecimentos diamantinos do Serro Frio (1881-25), 377-392. Bello Horizonte, 1899.

VEIGA, JOSE PEDRO XAVIER DA, DIRECTOR: (Documentos diversos.) Revista do Archivo Publico Mineiro. Anno V, fasciculos I e II, Janeiro a 
Junho de 1900. Relação do ouro fundido na Intendencia de Villa Rica, de Outubro de 1830 a Setembro de 1831,156 . Assento que se tomou sobre a descoberta de topazios, etc. (1772), 160-162. Bello Horizonte, 1900.

VkLAIN, CH.: Notes geologiques sur Haute-Guyane-d'aprés les explorations du Dr. Crevaux. Bull. Soc. Géol. de France, 3me série, Part I, Mars, 1879, VII, 388-395. Part II, Mai, 1881, IX, 396-417 (2 maps). Même chose avec la caption "Note geologiques sur in Haute-Guyane Française, d'après les explorations du Dr. Crevaux." Bul. de la Soc. de Gégraphie, 520-528. Paris, Dec., 1880.

VétaIN, CH.: Esquisse géologique de la Guayne Française e des bassins du Parou et du Yari (Affluents de l'Amazone), d'après les explorations du Dr. Crevaux. Bul. de la Soc. de Géogr.. 7me série, VI, 453-492. 4me Trimestre de 1885 (carte géologique). Paris, 1885.

VELLOSO DE MIRANDA: $\nabla$. MIRANDA, J. V. DE.

VEREKER, H. P.: Report on the Brazilian province of the Parana. Journal Royal Geographical Society, XXXII, 137-142. London (1862). Physical features. Abstract in Proc. Roy. Geog. Soc., VI, 74. London, 1862.

VERISSIMO (JOSE): Les populations anciennes du Brésil. Congres International d'Anthropologie et d'Archéologie Préhistoriques. Compte Rendu de la đixième session à Paris 1889, 501-507, $8^{\circ}$. Paris, 1891.

VERRILL, F. A.: Comparison of the Bermudian, West Indian and Brazilian coral faunæ. Trans. Connecticut Acad. of Arts and Sciences, XI, pt. I, 169-206. New Haven, 1901-1903.

VIANNA, FRANCISCO VICENTE: Memoria sobre o Estado da Bahia, feita por ordem do Exmo. Sr. Dr. Joaquim Manoel Rodrigues Lima. fovernador do Estado da Bahia. Bahia, 1893. The chanter "Mineraes," 62-101, treats of minerals as well as several references in the descriptions of cities and municipalities. This work is translated into English and published under the title, "Memoir of the State of Bahia, written by order of the Right Honorable Governor of the State of Bahia, Dr. Joaquim Manuel Rodrigues Lima, by the Director of Public Archives, Dr. Francisco Vincente Vianna, assisted by the Amanuensis of the same public office, Jose Carlos Ferreira." Translated into English by Dr. Guilherme Pereira Rebello. $8^{\circ}, 682+$ XXVII pp. Bahla, 1893. Minerals, 65, 86, 74, 77, 89, 90.

VIEIRA COUTO: V. COUTO.

VIENNOT, P. C.: I.e diamant. Annales de la société Linnéenne de Maine et Loire, 100-155, $8^{\circ}$. Angers, 1879.

vILLA FRANCA, BARAO DE: Turfas em Macahé e Campos. o Novo Mundo, Out. 23, 1875, VI, 19. New York, 1875. Extr. do Monitor Campista.

VILLANOVA MACHADO: $\nabla$. MACHADO.

VINCART, C.: L'exploitation de l'or av Brésil. Bibliothèque Norbertine, 8287. Louvain, 1903.

VITAL DE OLIVEIRA: $\nabla$. OLIVEIRA, M. A. VITAL DE.

VLASTO: Note sur quelques instruments en pierre, provenant de la cote nord du Brésil. Bulletins de la société d'Anthropologie de Paris. 3me sér., IV, 206-212, $8^{\circ}$. ill. Paris, 1881. Maranhão sections.

VOGEL, P.: Reisen in Mato Grosso 1887-88. (Zweite Schinga-Expedition) mit Anhang: Devonische Versteinerungen von Lagoinha in Matto Grosso (Brasillen) von Dr. Iudw. v. Ammon. Zeit. der Gesellschaft für Erdkunde zu Berlin, XXVIII, 1893, 243-295. 352. Berlin, 1893. See also Von Ammon.

VOIGT, W.: Bestimmung der Elasticitatsconstanten des brasilianischen Turmalines. Nachrichte von der Königl. Gesellschaft der Wissenschaften und der Georg-Augusto-Universatäts zu Gottingen. Jull. 1890. 279-294, with 1 plate. Annalen der Physik und Chemie. Neue Folge. XLI, 1890, 712-724. Leipzig, 1890. Abstract: Neues Jahrb. für Mineral., 1892, I, 8-9, (6) Referate. 
W., P.: Brazil. The land of gold. Supplement to the Mining Journal, L, 1460 . London, Dec. 18, 1880.

WAAGEN, W.: Mittheilung eines Briefes von Herrn A. Derbv über Spuren einer carbonen Eiszeit in Südamarika. Neues Jahrbuch Min., G. u. P., 1888, II, 172-176. Translated by Cotes in Records of the Geological Survey of Inaia, XXII, pt. 2, p. 69, 1889.

WADSWORTH, M. E.: Zirkelite: a question of priority, American Jour. Sci., 4th series, $V$ (CIV), 153. New Haven, 1898.

WAGONER, I.: Paraná e Santa Catharina. Revista Industrial, Janeiro de 1878 , II, 9-10. New York, 1878. Notes on geology and physical features. Dated Jefferson, Texas, Nor. 2, 1877.

WAGNER, A.: Bericht über die neuesten Leistungen von Lund, bezüglich der gegenwärtigen wie der ausgestorbenen Säugthier-Fauna Brasiliens. (Wiegmann's) Archiv für Naturgeschichte, 9er Jahrgang, I, 347-360. Berlin, 1843.

WALLACE, ALFRED R.: On the Rio Negro. Jour. Roy. Geog. Soc. (map), XXIII, 212-217. London, 1853.

WALIACE, ALFRED R.: A narrative of travels on the Amazon and Rio Negro, with an account of the native tribes and observations on the climate, geology and natural history of the Amazon valley, maps and ills., $8^{\circ}$. I condon, 1870. Notes on the geology, 201, 204, 222, 345, 352-3; geography and geology, 404-428.

WALLACE, A. R.: Review of Hartt's Geology and Physical Geography of Brazil. Nature, II, 510-512. London, 1870.

WALLACE, ALFRED RUSSEL: Darwinism; an exposition of the theory of natural selection (etc.). London and New York, 1889, 370. No proof of recent lower temperature in the tropics, 369-370.

WAILACE, ALFRED R.: Review of "The supposed glaciation of Brazil" by J. C. Branner. Nature, XLVIII, 589-590. London, 1893.

WAISH, REV. R.: Notices of Brazll in 1828 and 1829. 2 vols., $8^{\circ}$. London. 1830. Geology, mineral and mining, II, 90-224, 312. Another edition published at Boston, 1831. Geology, minerals and mining, II, IV-VIII.

WAPPÄUS, J. E.: Handbuch der Geographie und Statistik Brasilien. Handbuch de Geographie und Statistik füir die Gebildeten Stände begründet durch Dr. C. G. D. Stein und Dr. Ferd. Horschelmann. Neu bearheitet unter Mitwirkung mehrerer Gelehrten von Dr. J. R. Wappäus. 1 Band, 4 Abtheilung, 7th edition, 1226-1230, $8^{\circ}$. Leipzig, 1871.

WAPPAEUS, J. E.: A geographia physica do Brazil. Refundida (edição condensada). Rio de Janeiro, 1884. Chap. IV, aspecto physico, montanhas e chapadòes, 36-43. By O. A. Derby, q. v. Chap. V, estructura geologica e mineraes, 44-59, with map. By 0. A. Derby, q. v.

WARD, FANNIE B.: Diamonds of Brazil. San Francisco Chronicle, Nov. 11, 1894. Letter from Bom Jesus da Lapa, dated Aug. 30, 1894.

WARD, IESTER F.: The geographical distribution of fossil plants. Elghti Ann. Rep. of the U. S. Geol. Survey, Part II. Washington. 1880. Brazil, 823-824.

WARDEN (DAVID BAILIIE): Description géographique et historique du Brésil. 'Extrait des Annales d'Agriculture [182?]. Montagnes, volcans. mines.

WARMING, EUGEN: Ein Aufzug nach Brasiliens Bergen. Die Natur, Neue Folge, VII, 156-159, 170-172, 194-196, 208-209, $4^{\circ}$, ill. Halle, 1881.

WARMING, EUGEN: Lagôn Santa. It Biđrag til den biologisise Plantegeo grafi. Avec resumé en français, $4^{\circ}$, ill., 336. Kjöbenhavn, 1892. (Separate from $D$. Kgl. Danske Vidensk Selk., VI, 3 pp., 159-448.) Resumé, 303. 
336 ; sol et surface, 304 ; vegetation des rochers calcaires, 322 ; bibliographie, 448-452. (The bibliography is chiefly botanical, but with many geological titles.)

WARMING, EUG.: Lagôa Santa (Brésil) étude đe géographie botanique. Revue Génerale et Botanique, $\mathrm{V}, 145-158,209-223$, 1ll. Paris, $1893 . \quad \mathrm{Ab}-$ stract of the preceding title. Warming was the secretary of Lund, 1862 to 1866. His collections are described in Von Martius' Flora Brasiliensis.

WASHINGTON, HENRY s.: The foyaite-ijolite series of Magnet Cove: a chemical study in differentiation. Journal of Geology, Oct.-Nov., 1901, IX, 607-622; Nov.-Dec., 1901, IX, 645-670. Chicago, 1901.

WEBSTER, W. H. B.: A narrative of a voyage to the southern Atlantlc Ocean, in the years 1828, 29, 30, performed in H. M. Sloop "Chanticleer," under the command of the late Captain Henry Foster . . . from the private Journal of W. H. B. Webster, Surgeon of the sloop. 2 vols., $8^{\circ}$. London, 1834. Notes on Cape Frio, I, 31; Rio de Janeiro, I, 52-53. The geology of Fernando de Noronha, II, 326-331, 14-16.

WEINER, CHARLES: Die Sambaquis oder Muschelhausen in Brasillen. Das Ausiand, No. 45 (Nov. 6th), 895-897. Stuttgart, 1876.

WEIsS: Ueber das stidliche Ende des Gebirgszuges von Brasilien in der Provinz S. Pedro do Sul und der Banda Oriental oder dem Staate von VonteVideo; nach den Sammlungen des Herrn Fr. Sellow, von Hrn. Weiss. (Gelesen in der Acad. der Wissenschaften am 9 August, 1827, und Juni, 1828.) In- $4^{\circ}, 2$ plates, 217-293. Phys. Klasse, 1827 (Berlin), 1828.

WELLS, JAMES W.: Exploring and traveling three thousand miles through Brazil from Rio de Janeiro to Maranhão. In two volumes. London, 1866. Occasional geological notes. Appendix II, vol. II : Extracts from a paper read by the author at a meeting of the Royal Geographical Society on the 8th of Feb., 1886, and entitled "A sketch of the physical geography of Brazil," 359-374, map.

WELLS, JAMES W.: Notes of a Journey from the river St. Francisco to the river Tocantins and to the city of Maranhão. Jour. Roy. Geog. Soc., XLVI, 308-328, map. London, 1876.

WELLS, JAMES W.: A sketch of the physical geography of Brazil (map). Proceedings of the Royal Geographical Society, VII, 353-371. London, 1886.

WELLS, JAMES W.: Notes of a visit made to the delta of the River Tocantins, Brazil. Proceedings of the Royal Geographical Society, VIII, 513517. London, 1886.

WELLS, JAMES W.: Brazil. Journal of the Society of Arts, XXXVIII, 445460. London, 1890. Notes on physical features and minerals.

WENDEBORN, ROB.: The Ouro Preto gold mines of Brazil. Limited from 1886. Abstract: Berg- $u$. Hütten. Zeit., 1887, 46 Jahrg., 111. Leipzig, 1887.

WERNEKINCK, DR.: Ueber den Sideroschisolith von Congonhas do Campo in Brasilien. Pogg. Annalen der Physik u. Chemie, I, Heft 4, 387-396. Leipzig, 1824. Abstract under title, "Sur les sidero-schisolithes de Congonhas do Campo dans le Brésil." Bulletin des sciences naturelles et de Qéologie, No. 10, Oct., 1825, 201-202. Paris, 1825.

WESTERGÅRD, A. H.: Über Turmalin von Minas Geraes in Brasilien. Groth's Zeit. $f$. Krystallographie. B. XLII, 3 Heft, 278-279. Leipzlg, 1906.

WEULE, KARL: Beiträge zur Morphologie der Flachküsten. e InauguralDissertation zur Erlangung der philosophichen Doctorwürde Vorgelegt der hohen Philosophischen Fakultät der Universität, Leipzig. Mit 8 Karten und 6 profilen auf 1 Blatt, $4^{\circ}$. Weimar, 1891. Coast lakes of southern Brazil, 35-37, 44. 
WHITE, CHARLES A.: Contribuições a paleontologia do Brasil (com o orig. inal em inglez). Archivos do Museu Nacional, VII, $4^{\circ}, 1-273$, and 28 plates. Rio de Janeiro, 1887 . 350 copies of this report were issued as a special edition, dated Washington, Jan. 21, 1888, under the title, "Contributions to the paleontology of Brazil ; comprising descriptions of Cretaceous invertebrate fossils mainly from the provinces of Sergipe, Pernambuco, Para and Bahia. By Charles A. White." Notice: Amer. Jour. Sci., CXXXV, 255. New Haven, 1888. Notice: Neues Jahrb. f. Min., 1890, I, 358-359 Referate.

WHITE, DAVID: Flora of the Brazilian coal measures. Science, XXI, 700, May 5, 1905.

WHITE, DAVID: Permo-carboniferous climatic changes in South America. Journal of Geology, XV, 615-633, Oct.-Nov., 1907.

WHITE, DAVID: Permo-carboniferous changes in Brazilian South America, indicated by fossil plants. Science, XXV, 772, May 17, 1907.

WHITE, DAVID: Report on the fossil flora of the coal measures of Brazil. Appendix of I. C. White's Report on the Coal Measures of South Brazil. (In 'press) Rio de Janeiro.

WHITE, I. C.: The coal measures of Brazil. Science, XXI, 699-700, May 5, 1905.

WHITE, I. C.: Geology of South Brazil. Science, XXIV, 377-379, Sept. 21, 1906. (Includes a list of fossil plants from the coal fields of Brazil.)

WHITE, I. C.: O carvão Birasileiro. Boletim da Directoria de Agricultura etc. do Estado da Bahia, VIII, 134-142. Bahia, 1906. (Tirado do Jornal do Commercio do Rio 13 de Março de 1906.

WHITE, I. C.: Coal measures and higher beds of South Brazil. Science, XXV, 772, May 17, 1907.

WHITE, I. C.: Report on the coal measures and associated rocks of Soutl Brazil. In English and Portuguese, report to the Minister of Industry, etc. Rio de Janeiro, $4^{\circ}$, ill. (In press.)

WHITFIELD, J.: Rock inscriptions in Brazil (Ceara). Jour. Anthropological Institute of Great Britain and Ireland, III, 114-115, $8^{\circ}$, ill. London, 1874.

WIFGERS, F.: Mineralquellen und Erzlagerstätten aus dem unteren Amazonasgebiete. (Aus F. Katzer's Geologie, etc.) Zeit. für praktische Geologie, XII, 57-58. Berlin. 1904.

WIENER, CARIOS: Estudos sobre os sambaquis do Sul do Brazil. Archivos do Museu Nacional, I, 1-20, $4^{\circ}$. Rio de Janeiro, 1876.

WIGG, CARLOS: (Average analyses of four cargoes of manganese from Minas.) Annual report of the Director of the Bureau of American Republics for the year 1899, pt. II, 1964. Washington, 1900 ,

WIGG, CARIOs: Brazilian manganese ore. (Complete analysis.) Engineering and Mining Journal, LXXXIII, 345. New York, Feb. 16, 1907.

WILIIAMS, CHAS. H.: Brazillan mines. Supplement to the Mining Journal, LII, 1069. London, Sept. 2, 1882.

WILIIAMS, GARDNER F.: The diamond mines of South Africa; some account of their rise and development. Ill. New York, 1902. Brazilian diamond mines, 140-145.

WIIIAMS, GEO. H.: Description of the rhyolite from Santo Aleixo and Ilhas, Province of Pernambuco. The Cretaceous and Tertiary geology of the Sergipe-Alagôas basin of Brazil. By J. C. Branner. Trans. Amer. Phil. Soc., 1889, XVI, 404, footnote.

WIIIIAMS, GEO. H.: Geology of Fernaudo de Noronha. Petrography. Part II. [For part I, see Branner.] Amer. Jour. Sci., CXXXVII, 178-189. New Haven, 1889. Abstract of Parts I and II in Neues Jahrbuch für Mineral., 1890, I, 85 Referate. Stuttgart, 1890. 
WILLIAMson, E.: Geology of Paraiba and Pernambuco gold regions. Trans. Manchester Geological Society, VI, 113-122. Sessions of 1886-7. Manchester, 1868. Translation: Geologia das regiōes auriferas de Parahyba e de Pernambuco. Traduzida do Inglez por Alfredo de Carvalho. Revista do Instituto Archeologico e Geographico Pernambucano, No. 60, 110-118. Recife, 1904.

WILLISTON, s. W.: (Description of a new species of Gimolichthys from Parahyba do Norte.) Bul. Geol. Soc. Amer., XIII, 44-45, ill. Rochester, 1902.

WILIISTON, s. W.: American Amphicolian crocodiles. Jour. Geology, XIV, Chicago, Jan.-Feb., 1906. Hyposaurus derbianus, 4-5.

WILSON-BARKER, D.: The connection of meteorology with the other sciences. Quarterly Jour. Royal Meteorological Soc., XXXI, No. 134, 85-95. London, April, 1905. References to Pernambuco reefs, 87-88; to Fernando de Noronha, 90-91.

WINGE, HERLUF: Jordfundne og nulevende Gnavere (Rodentla) fra Lagôa Santa, Minas Geraes, Brasilien. Med Udsigt over Gnavernes indbyrdes Slaegtskab. $E$ Museo Lindii (see Lütken), I, 3rd paper, 1-178, followed by abstract in French. $4^{\circ}, 8$ pls. Kjöbenhavn, 1888.

WINGE, HERLUF: Rongeurs fossiles et vivants de Lagôa Santa, Minas Geraes, Brésil. Avec un aperçu des affinités mutuelles des rongeurs. (Extraits du mêmoire danois par les soins de l'éditeur.) E Museo Lundii. En Samling af Afhandlinger om de $i$ det indre Brasiliens Kalkstenshuler af Professor $P$. $W$. Lund udgravede Dyre-og Menneskeknogler, I, III paper, 179-200, 8 planches. Kjöbenhavn, 1888-1896.

WINGE, H.: Chauves-souris fossiles et vivantes de Lagỏa Santa, Minas Geraes, Brêsil. Avec un aperçu des affinités mutuelles des Chiroptères (Apercu du ménoire danois publié par les soins de l'editeur). E B $\mathbf{B}$ useo Lundii. II, 67-92, 2 planches. Kjöbenhavn, 1893. Abstract: Neues Jahrbuch fïr Mineral., 1896, II, 488-494 Referate.

WINGE, HERLUF: Jordfundne og nulevende Pungdyr (Marsupialia) fra Lagộa Santa, Minas Geraes, Brasilien. E Museo Lundii (see Lütken), II, 2nd paper, 1-135, $4^{\circ}$, plates. Kjöbenhavn, 1893.

WINGE, HERLUF: Jordfundne og nulevende Flagermus (Chiroptera) fra Iagôa Santa, Minas Geraes, Brasilien. E Museo Lundii (see Lütken), II. paper 1, 1-66, plates. Kjöbenharn. 1893.

WINGE, HERLUF: Marsupiaux fossiles et vivants de Lagôa Santa, Minas Geraes, Brésil. Avec un apercu sur les affinites des Marsupiaux. $E$ Musen Lundii, II, paper II, 134-149, 4 planches. Kjöbenhavn, 1893. Abstract: Neues Jahrb. für Mineral., 1896, II, 488-494 Referate.

WINGE, H.: Singes (Primatés) fossiles et vivants de Lagôa Santa, Minas Geraes, Brésil. Avec un aperçu des affinités mutuelles des Primałés. (Résumé du mếmoire danois, publiế par les soins de l'éditeur.) E Museo Lundii (see Lütken), II, paper V, 47-57, 2 planches. Kjöbenhavn, 18951896. Abstract: Neues Jahrb. $f$. Mineral., 1898, II, 507-509 Referate.

WINGE, H.: Carnivores fossiles et vivants de Lagôa Santa, Minas Geraes, Brésil. Avec un aperẹu des affinités mutuelles des Carnassiers. E Museo Lundii (see Lütlen), II, part II, paper IV, 105-130, 8 planches. Kjöbenhavn, 1895-1896. Abstract by Schlossen: Neues Jahrbuch für Mineralogie, 1899, II, 144-147. Stuttgart.

WINGE, HERLUF: Jordfundne og nulevende Aber (Primates) fra Lagôa Santa, Minas Geraes, Brasilien. Med Udsigt over Abernes indbyrdes Slægtskab. $E$ II useo Lundii (see Liitken), II, part II, paper III, 1-46, $4^{\circ}$, plates. Kjöbenbavn, 1895-1896.

WINGE, HERLUF: Jordfundne og nulevende Rovdyr (Carnivora) fra Lagôa Santa, Minas Geraes, Brasilien. Med Udsigt over Rovdyrenes indbyrdes Slregtskab. E Museo Lumdii (see Lïtken), II, part II, paper IV, 1-104, 8 plates. Kjöbenhavn, 1895-1896. 
WINGE, H.: Jordfundene og nulevende Hovdyr (Ungulata) tra Lagoa Santa, Minas Geraes, Brasilien. Med udsigt over Hovedyrenes indbyrdes Slaegtskab. Kjöbenhavn (E. Museo Lundii), 1906. 239 pg. 9 Taf. Kart.

WINGE, 0.: Résumé du mêmoire de M. 0 . Winge sur les oiseaux des cavernes $\mathfrak{a}$ ossements du Brésil. $\boldsymbol{B}$ M useo Lundii. En Samling af Afhandlinger om de $\mathrm{i}$ det indre Brasiliens Kalkstenshuler. af Prof. P. W. Lund (see Liitken), I, paper II, 1-5, 1 plate. Kjöbenhavn, 1888. The papers are separately paged.

WINGE, OLUF: Fugle fra Knoglehuler I Brasilien. $E$ Museo Lundi, I, 2nd paper, 1-54, followed by a resume in French, five pages. Kjöbenhavn, 1888.

WOHLER, FR.: $\nabla$. HAUSMANN.

WOHLTMANN, DR.: Ein Beitrag zu den Muschelbergen, Sambaquis an der Ostkitste Brasillens. Zeit. für Naturw., LXIII, 305-312.

WOHLTMANN, DR.: Dle Sambaquis, Muschelberge oder prihistorischon Küchenabfälle an der Ostküste Stidbrasiliens. Correspondenz-Blatt der deutschen Gesellschaft filr Antropologie Ethnologie und Drgeschichte. 22nd year, 14-15. Mutnchen, Feb., 1891.

WOLLASTON, W. H.: On the discovery of palladium, with observations on other substances with platinum. Phlosophical Transactions. XCV. 316. London, 1808. Natjve palladium in Brazillan platinum-bearing sands.

WOLLAstor, W. H.: On platina and native palladium from Brasil. Philosophtcal Transactions of the Royal Soclety of London for 1809, part II. 189-194. London, 1809.

WOLIASTON, W. F.: Observations and experiments on the mass of native Iron found in Brasil. Philos. Transactions of the Royal Soc. of London for the year 1816, part I, 281-285. London, 1816.

WOODWARD, A. SMITH: On the Fossll Teleostean genus Rhacolepis, Agass. Proc. of the Zoological Bociety of London, 1887, 535-542, with 2 plates. Fossil fishes from Barra do Jardim, Ceara. Rhacolepis buccalts, $R$. brama, R. latus.

WOODWARD, A. SMTTH: Notes on some vertebrate fosslls from the Province of Bahla, collected by Joseph Mawson, Esq., F. G. S. Annals and Magazine of Natural History, 1888, 6th series, II, 132-136.

WOODWARD, ARTHUR SMITH: Catalogue of the fossil fishes in the British Museum (Natural History). Iondon, 1889. Part III, 1895, 435-437, Belonstomus comptoni Agg., Upper Oretaceous of Ceara. All from Barra do Jardim. Part IV, 1901, 27-29, Notelops brama (Ag.). (Agassiz's Rhacolepsis Alfersii) from Upper Cretaceous, Ceara, Barra do Jardim. Part IV, 1901, 29-31, Rhacolepsis buccalis Ag., from Barra do Jardlm, Ceará. Part IV, 1901, 32, Rhacolepsis latıs Ag., Barra do Jardim, Ceara. Part IV, 1902, 108-109, Cladacylus gardneri Ag., Ceara.

WOODWARD, A. SMITH: On some upper Cretaceous fishes of the family of Aspidorhynchida. Proc. Zool. Soc., London, 1890, 629-636. London. 2 plates. Betoriostomos comptoni Ag., Ceara, Serra de Araripe.

WOODWARD, A. SMITH: Vertebrate palaeontology in some American and Ganadian Museums. Geological Magazine, Sept., 1890, new ser., VII, 394. London, 1890. Brazilian vertebrate fossils in the collection of E. D. Cope.

WOODWARD, A. SMITH: Evidence of the occurrence of Pterosaurians and Plesiosaurians in the Cretaceous of Brazll, discovered by Joseph Mawson. Annals and Magazine Natural History, 6 ser., $\mathrm{V}, 8,314-317,2$ figs. London, 1891. Abstract: Neues Jahrb. f. Mineral., 1893, I, 163-164 Referate.

WOODWARD, A. SMITH: On two deep-bodied species of the clupeoid genus Diplomystus. Ann. and. Mag. Nat. Hist., 6th series, XV. London, 1895. 1-3 (plate and figures). Abstract: Neues Jahrbuch für Mineral., 1898, II, 145 Referate. 
WOODWARD, A. SMITH: On the quadrate bone of a gigantic Pterodactyle discovered by Joseph Mawson in the Cretaceous of Bahia, Brazil. Ann. and. Mag. of Nat. Hist., 6 ser., XVII, 255-257, 3 figs. London, 1896. Abstract: Neues Jahrb. $f$. Mineral., 1898, I, 377 Referate.

WOODWARD; ARTHUR SMITH: On a new specimen of the Mesosaurian reptile, Stereosternum tumidum, from S. Paulo, Brazil. Geological Magazine, N. S., Decade 4, IV, No. 394, 145-147, 1 pl. London, 1897.

WOODWARD, A. SMTTH: Consideraçôes sobre alguns peixes Terclarios dos schistos de Taubaté, Estado de S. Paulo, Brazil. Revista do M useu Paulista, III, 63-75. S. Paulo, 1898. Abstract: Neues Jahrb. f. Mineral., 1901, II, 149, Referate.

WOODWARD, A. SMITH: On an Amioid fish (Megalurus mawsoni, sp. n.), from the Cretaceous of Bahia, Brazil. Ann. and Mag. Nat. Hist. (7), LX, 87-89, 1 plate. London, 1902.

WOODWARD, A. SMITH: On some Dinosaurlan bones from South Brazll. Geological Magazine, X, 512. London, Nov., 1903. Traces of Gondwanaland fauna from red beds of Rio Grande do Sul. Abstract: Rep. 73rd meeting Brit. Assoc. Adv. Sci., 663. London, 1904.

WOODWARD, A. SMITH: On some fossil reptilian bones from the state of Rio Grande do Sul, Brazil. Geological Magazine, June, 1908, 251-255, ill. Same in Revista do Musen Paulista, VII, 46-57. Abstract: Brit. Assoc. Rep., 1904, 663 .

WOODWARD, A. SMITH: See MAWSON, JOSEPH.

WOODWARD, HENRY: The Tertiary shells of the Amazons valley. Annals and Magazine of Nat. Hist., 4th ser., VII, 59-64, 101-109. London, 1871. Abstract: Zeitschrift fïr die Gesammten Naturwissenschaften von $C$. $G$. Giebel, N. F., 1871, III, 235-236. Berlin, 1871.

WOOLNOUGH, W. G.: จ. DAVID.

WRIGHT, FRED. E.:.Die foyaitisch-theralltischen Eruptlvgesteine der Insel Cabo Frio, Rio de Janeiro, Brasilien. Tschermak's Mineralogische und Petrographische Mittheilungen, N. F., XX, III Heft, 233-259; IV Heft, 273-306. Wlen, 1901.

WRIGHT, MARIE ROBINSON: The new Brazll: Its resources and attractions, historical, deseriptive and industrial. $4^{\circ}$. Philadelphia (ca. 1901). Mineral wealth, etc., 251-262 ; Minas Geraes, 265. The work also contains many illustrations of geologic interest.

WtIFING, E. A.: Uber einige krystallographische Konstanten des Turmalins und ihre Abliaingigkeit von seiner chemischen Zusammensetzung. Programm zur 82 Jahresfeier der $k$. wïrtt. landwirtschaftl. Akademie Hohenheim. Stuttgart, 1900. 99 and 1 plate.

XAVIER DA VEIGA: $\nabla$. VFIGA, J. P. $X$. DA.

XAVIER, FONTOURA: The mineral wealth of the Republic (of Brazil). Quoted from the International Economist of . . . in the Monthly Bulletin of the International Bureau of American Republics, XII, 1423-1426. Washington, 1902.

YOUNG, ERNESTO GUITHERME: Mineraça do ouro. Subsidios para a historia de Iguape. Revista do Instituto Historico e Geographico de $\mathbf{s}$. Paulo, VI, 400-435. São Paulo, 1902.

ZALUAR, A. F.: A Commissão Geologica do Brazil. O Vulgarizador, Rlo de Janeiro, 3 de Nov. de 1877. O Novo Mundo, Janeiro de 1878, VIII, 18-19. New York, 1878.

ZEILLER, R.: Sur quelques empreintes vegetales des gisements houlllers du Bresil méridional. Comptes Rendus de l'Acad. Sci., CXXI, 961-964. Paris, 1895. Abstract: Gliickauf, XXXII, 33. Essen, 1896. Abstract: Jour. Iron and steel Institute, XLIX, 343. London, 1896.

ZEILLFR, R.: Note sur la flore fossile des gisenents houllers de Rio Grande do Sul. Bul. Soc. Géol. de France, 3d ser., XXIII, 601-623 (3 plates). Paris, 1895. 
ZEILLER, R.: Sur un Lepidodendron silicifié du Brêsil. Comptes Rendus de l'Acad. Sci., CXXVII, 245-24T. Paris, 1898.

ZIEGLER, A.: Die Brasilianische "Expedição scientifica" und die Arbeiten des A. Conçalves Dias. Petermann's Mittheilungen, 1863, 71. Gotha, 1863.

ZIMANYI, K.: Die Hauptbrechungsexponenten der wichtigeren Gesteinsbildenden Mineralien bei Na-Licht. Zeitschrift für Krystalog., XXII, 321-358. Leipzig, 1894. Tourmalin von Brasilien, 334.

ZIMMFRMAN, E. A. W. VON: Taschenbuch der Reisen, oder unterhaltende Darstellung der Entdeckungen des 18th Jahrhunderts, etc. Siebenter Jahrgang für das Jahr 1808. Leipzig (n. d.), $12^{\circ}$. Notes on geology and gold, diamonds and other stones, 38-57.

zINCKEN, J. CARL L.: Beschreibungeiniger Brasilianischer Mineralien. Journal für Chemie und Physik . . . herausgegeben von J. S. C. Schweigger (und Dr. Meinecke), XXVI, 372, 379. Nürnberg, 1819.

ZITIEL, KARL A.: Traite de Paléontologie. Traduit par Charles Barrois. III. Paléozoologie, Vertebrata, Mesosauridae, 588-589. Paris, 1898. 